\title{
19. CENOZOIC RADIOLARIA (EXCLUSIVE OF THEOPERIDS, ARTOSTROBIIDS AND AMPHIPYNDACIDS) FROM THE GULF OF MEXICO, DEEP SEA DRILLING PROJECT LEG 10
}

\author{
Annika Sanfilippo and W.R. Riedel, Scripps Institution of Oceanography, La Jolla, California
}

\section{CONTENTS}

1. Introduction

2. Radiolarian and non-radiolarian sediments (with Figures 1-3)

3resentation of results

4. Morphotypic-evolutionary limits of taxa (with Figure 4)

5. Radiolarians at each site

(1) Site 86 (Tables 1 and 2)

(2) Site 94 (Tables 3 and 4)

(3) Site 95 (Tables 5 and 6 )

(4) Site 96 (Tables 7 and 8)

491

494

6. Time-ranges of taxa (with Table 9 and

Figures 5 and 6)

7. New information of phylogeny

\section{INTRODUCTION}

Of the drilling sites occupied during Leg 10 of the Deep Sea Drilling Project, the following yielded sufficient Cenozoic radiolarians to be incorporated in this study:

Site 86: $22^{\circ} 52.75^{\prime} \mathrm{N}, 90^{\circ} 57.55^{\prime} \mathrm{W}$; water depth $1481 \mathrm{me}-$ ters.

Site 94: $24^{\circ} 31.64^{\prime} \mathrm{N}, 88^{\circ} 28.16^{\prime} \mathrm{W}$; water depth 1793 meters.

Site 95: $24^{\circ} 08.8^{\prime} \mathrm{N}, 86^{\circ} 23.9^{\prime} \mathrm{W}$; water depth 1633 meters.

Site 96: $23^{\circ} 44.56^{\prime} \mathrm{N}, 85^{\circ} 45.8^{\prime} \mathrm{W}$; water depth 3439 meters.

H.P. Foreman, in a separate chapter in this volume, presents the results of her investigation of the Cenozoic theoperids, artostrobiids and amphipyndacids from this leg, as well as of all of the Cretaceous radiolarians. Our investigation covers the remaining families of Cenozoic radiolarians, and has proceeded in a manner similar to that employed on the Leg 7 radiolarians (Riedel and Sanfilippo, 1971). As in that earlier paper, this report covers only a small proportion of the large number of radiolarian taxa present-those that are most obviously of biostratigraphic or taxonomic significance, or are otherwise noteworthy.

The Early Eocene and Late Paleocene samples recovered on Leg 10 provide an opportunity for fundamental advances in our understanding of the taxonomy and stratigraphy of radiolarians of those ages, and therefore attention has been focused on them particularly. The younger material, recovered in less complete sequences, is here

8. Systematic section

(1) Collosphaeridae

(2) Actinommidae

(3) Litheliidae

(4) Phacodiscidae

522

(5) Coccodiscidae

522

(6) Spongodiscidae

523

(7) Acanthodesmiidae

523

(8) Plagoniidae

526

(9) Carpocaniidae

(10) Pterocoryidae

529

530

(11) Cannobotryidae

531

532

9. Acknowledgments

532

533

11. Plates [comprising the synchronopticon (Plates 1-21) and other plates (22-36)]

12. Index of radiolarian names

treated less thoroughly-its prinicipal value is in permitting a partial comparison of the succession of radiolarians in the Gulf of Mexico with those of other paleobiogeographic regions.

\section{RADIOLARIAN AND NONRADIOLARIAN SEDIMENTS}

The distribution through time of the Leg 10 radiolarian sediments, and also of calcareous sediments lacking siliceous microfossils, is plotted in Figure 1. The age scale against which the cores are plotted represents the foraminiferal zone assignments, despite the fact that the resulting correlations conflict somewhat with the radiolarian results as pointed out by H.P. Foreman in her chapter of this volume. This figure shows that sediments in the Gulf of Mexico younger than the early or middle Miocene generally lack siliceous microfossils, whereas older strata commonly contain them. That this generalization applies also (though less neatly) to other parts of the Gulf of Mexico and Caribbean is indicated by Figures 2 and 3, in which the results from sites drilled in this region during Legs 1 and 4 are plotted in a similar manner. It seems possible that this change from radiolarian to nonradiolarian sediments in the late Early or early Middle Miocene could be due to a decrease in the rate of production of siliceous microfossils, occasioned by a diminution of the inflow of fertile Pacific water (from the equatorial current system and the Humboldt Current) across the area now occupied by the Isthmus of Panama. However, before such a simple explanation can be accepted, it will be necessary to investigate the possibility that solution of the siliceous microfos- 
A. SANFILIPPO, W. R. RIEDEL

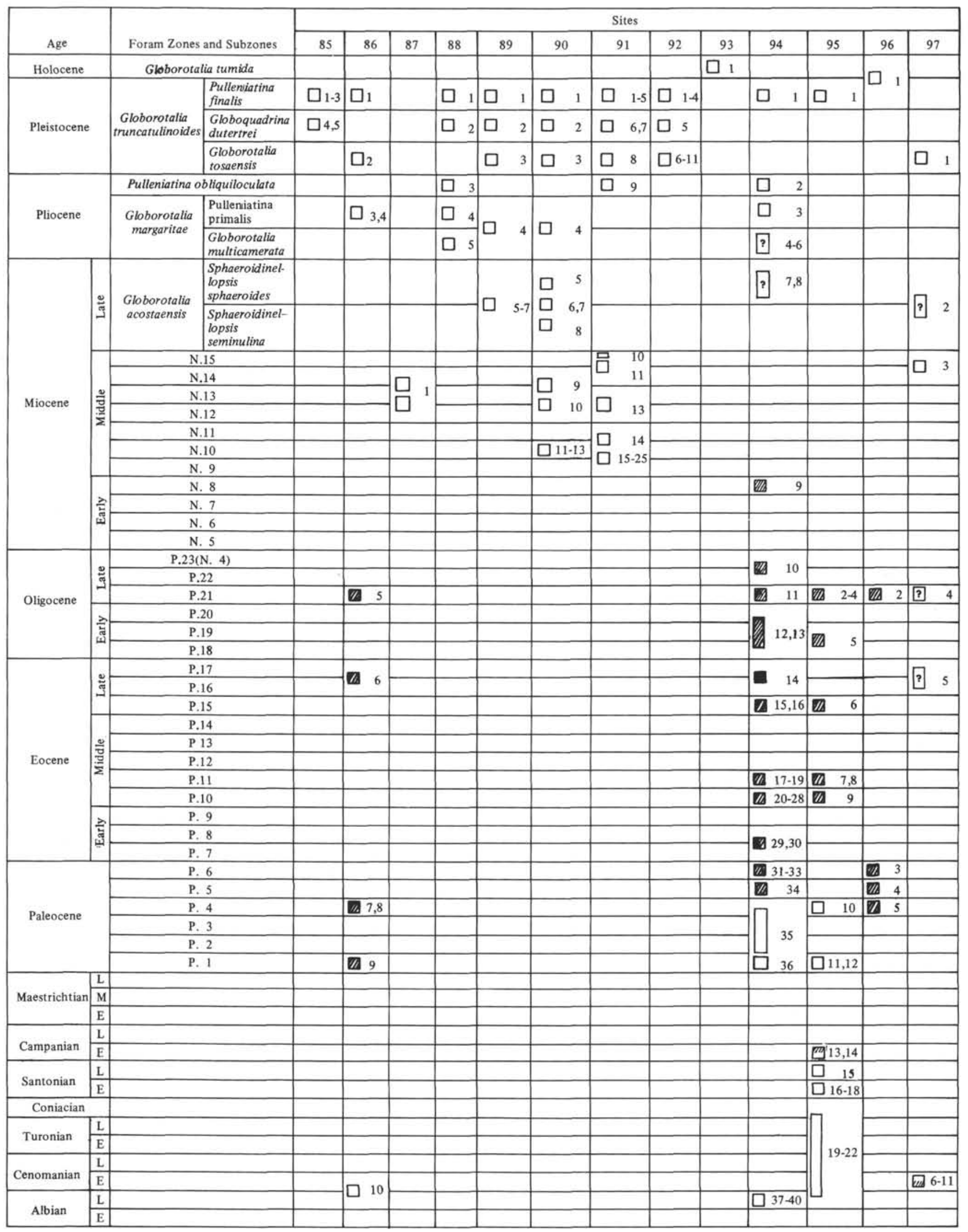

Figure 1. Sediments cored on Leg 10 in the Gulf of Mexico. Cores are represented by numbered rectangles. Empty rectangles represent calcareous cores lacking siliceous microfossils, and hachuring indicates siliceous microfossils occurring in calcareous sediments. 


\begin{tabular}{|c|c|c|c|c|}
\hline & & & Sites & \\
\hline Age & Zones & 1 & 2 & 3 \\
\hline Quaternary & & $1-9$ & 1,2 & $1-4$ \\
\hline \multirow{3}{*}{ Pliocene } & N. 21 & & 3 & 5,6 \\
\hline & N. 20 & & \multirow{2}{*}{4} & 7 \\
\hline & N. 19 & & & 8 \\
\hline Late Miocene & & & & $9-11$ \\
\hline $\begin{array}{l}\text { Late Middle } \\
\text { Miocene }\end{array}$ & & & 5 & \\
\hline
\end{tabular}

Figure 2. Sediments cored on Leg 1 in the Gulf of Mexico. Cores are represented by numbered rectangles, empty to indicate calcareous sediments lacking siliceous microfossils.

sils after burial might explain their absence from some of the calcareous sediments.

\section{PRESENTATION OF RESULTS}

The procedure of investigation and the method of presentation of results are so similar to those employed in our investigation of the radiolarians from Leg 7 (Riedel and Sanfilippo, 1971) that only brief comments are necessary here.

The practice of tabulating abundances of morphotypes in each of the assemblages examined (Tables 1-8), and transforming as many of these as possible into evolutionary limits of taxa in the construction of a list of events (Table 9) and a range chart (Figures 5 and 6), has proven to be a useful procedure, since it permits evaluations of the degree of reliability of the biostratigraphic interpretations. It is exceedingly difficult, if not impossible, to compare results between legs of the Deep Sea Drilling Project for which observations are not presented in this degree of detail (e.g., the report of the radiolarians from Leg 5).

Because of the long period of geologic time represented by the Cenozoic radiolarian sediments, and consequently the large number of taxa present, the tabulations of radiolarians at each site are divided into two parts-one covering the samples younger than Middle Eocene, and the other the older samples. A synchronopticon is presented for the radiolarian succession from the late Paleocene to the Theocampe mongolfieri Zone (early Middle Eocene).

In the various tables and lists, some radiolarian names are abbreviated-their full and correct forms are given in the systematic section. New radiolarian zones for the
Early Eocene and Late Paleocene are defined by H.P. Foreman in her chapter in this volume. The base of each of the new zones is defined by the earliest appearance of the nominative taxon-the earliest morphotypic appearance in the case of the Bekoma bidarfensis Zone, and the earliest evolutionary appearances in the case of the other zones.

\section{MORPHOTYPIC-EVOLUTIONARY LIMITS OF TAXA}

A significant difference between the presentation of the radiolarian results here and for Leg 7 (Riedel and Sanfilippo, 1971) is in the recognition of a third type of stratigraphic limit of a radiolarian taxon. In the earlier report, we distinguished between morphotypic limits ( $m$-for taxa whose ancestors and/or descendants are not known, and for the lower limits of taxa known to have evolved from an ancestor that ranges upward for a considerable time beyond the origin of the descendent) and evolutionary limits ( $e$-for extinctions at the terminations of evolutionary lineages, and points of arbitrary subdivision of continuous evolutionary lineages in which the ancestor does not long persist together with the descendant). It now seems desirable to separate as morphotypic-evolutionary (m-e) the second type of limit formerly included under the term morphotypic - namely, the lower limit of a taxon known to have evolved from an ancestor that ranges upward for a considerable time beyond the origin of the descendant. This morphotypic-evolutionary type of limit may be expected to have greater reliability for purposes of stratigraphic correlation than the cryptogenetic limits to which the term morphotypic is now restricted. Figure 4 illustrates the three types of limits distinguished in this chapter.

Application of the concept expressed by the new term morphotypic-evolutionary will not involve a change in the time-significance of such an event, which was formerly termed simply morphotypic. However, when a cryptogenetic event (formerly termed morphotypic) can as a result of later work be recognized as part of an evolutionary lineage with little overlap between ancestral and descendant morphotypes, and is thus replaced by an evolutionary limit, its time-significance (and position in a sequential list of events such as Table 6, Riedel and Sanfilippo, 1971) will in most cases be changed.

\section{RADIOLARIANS AT EACH SITE}

Tables 1 through 8 show the distribution of radiolarian taxa (morphotypes) at Sites $86,94,95$, and 96. Information in the column headed "Preservation and Abundance" was provided by H.P. Foreman. Abundance of total radiolarians in a sample is indicated by $R$ (rare), $F$ (few), $C$ (common), or $A$ (abundant), and preservation is indicated by $P$ (poor), $M$ (moderate), or $G$ (good).

In the columns showing occurrences of species, the same abundance terms (with the addition of " + " for very rare) are used to indicate the proportion that a given species constitutes of the total radiolarian assemblage, in a strewn-slide of normal density in which the radiolarians are not diluted by other sedimentary components. The notation "+" (very rare) is used only when less than three 


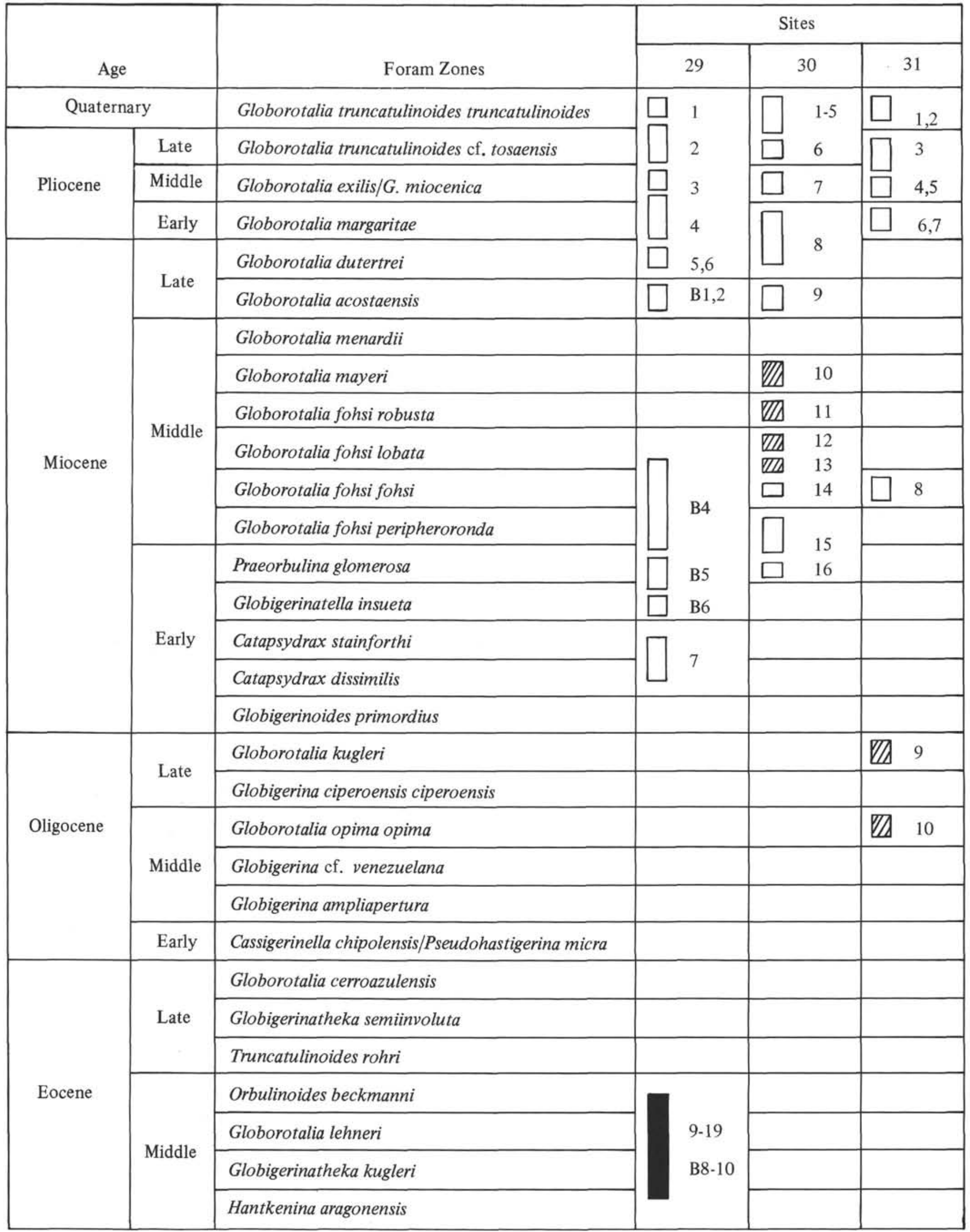

Figure 3. Sediments cored on Leg 4 in the Caribbean. Cores are represented by numbered rectangles. Empty rectangles represent calcareous cores lacking siliceous microfossils, hachuring indicates siliceous microfossils occurring in calcareous sediments, and black rectangles represent siliceous sediments lacking calcareous microfossils. 


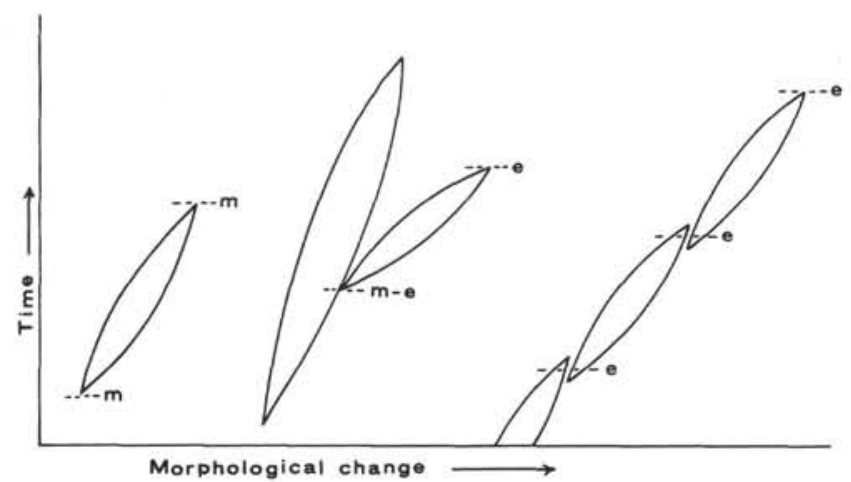

Figure 4. Illustrating the three types of limits between taxa: $\mathrm{m}$, morphotypic; m-e, morphotypic-evolutionary; and e, evolutionary. The width of each lanceolate figure at a particular level represents the number of specimens having that morphology at that point in geologic time.

specimens of the species are found in one strewn-slide (which normally contains an assemblage of about 20,000 to 30,000 individuals, under a $23 \times 40 \mathrm{~mm}$ coverglass). The term abundant is practically never used, since it is reserved for occurrences of an unusually high proportion of a species in an assemblage. And the other three terms are used as an approximate scale between these two extremes. A dash is used to indicate absence of a species from a sample in which it was searched for. Occurrences believed to result from the reworking of older forms into younger sediments, or from downward caving resulting in introduction of younger forms into older assemblages, are marked with an exclamation mark (!). An $x$ is used to indicate that the slide was inadequate (usually as a result of dissolution or excessive sieving) to provide information on the species sought.

\section{TIME-RANGES OF TAXA}

The information on occurrences of Cenozoic radiolarian species at Sites $86,94,95$, and 96 is synthesized in the form of a chronologically arranged list of radiolarian events (upper and lower limits of the ranges of taxa, and evolutionary transitions), and a range-chart.

The list of events (Table 9) is in almost the same form as that presented in our report on the radiolarians from Leg 7, but with some refinements. In the column with the names of taxa, $T$ indicates the top of the range of a taxon, $B$ its bottom, and an arrow an evolutionary transition. The abbreviations $e, m$, and $m-e$ indicate evolutionary, morphotypic, and morphotypic-evolutionary limits, respectively (see text Section 4). In the body of the table are given the pairs of core sections between which an event occurred, followed by the depth in meters below the sediment surface in parentheses-these latter numbers are approximate to the extent that half-meters (used in H.P. Foreman's chapter in this volume) are rounded upward to the next full meter. The degree of reliability (for purposes of correlation) of each event at each site is indicated by the letters P, M, and G (for poor, moderate, and good). A zero in the list of events indicates that the species concerned was not encountered in the material cored at that site.

In contrast to the situation prevailing during the preparation of our report on the Leg 7 radiolarians, we have been able during our investigation of the Leg 10 material to benefit from results from previous legs of the Deep Sea Drilling Project. Thus, in the preparation of the list of radiolarian events, a group of events occurring in a gap between cores can in some cases be arranged in stratigraphic order on the basis of results from earlier legs. This is indicated by columns of brackets on the left-hand side of Table 9. The primary ordering of the list of events is based on the Leg 10 results, and brackets in the column nearest the list of names indicate groups of events that cannot be separated on the basis of materials collected on this leg. A bracket including a single event is represented by a dash. Brackets in columns for Legs 4,7 , and 8 indicate how the events within the Leg 10 groups can be separated on the basis of the results from those earlier legs. Groups of events which cannot be arranged in stratigraphic order after applying this procedure are listed alphabetically by specific name. For the time interval bracketed by the bottom of the range of Botryocyrtis spp. and the top of the range of Theocyrtis annosa, the order of events in the Leg 10 material seems to differ from that observed in the Leg 7 cores, and this conflict is indicated by two sets of brackets in the Leg 7 column.

We have included earliest and latest occurrences of theoperids, artostrobiids, and amphipyndacids (from information provided by H.P. Foreman) in this table for several reasons. First, it seems convenient to have a comprehensive list of this type, including all Leg 10 radiolarians. Second, comparison of Leg 10 results with those of previous legs has permitted the stratigraphic subdivision of some large groups of events that occurred in gaps between Leg 10 cores. And thirdly, we have evaluated the reliability of each theoperid and artostrobiid event on the basis of Foreman's species tabulations, and have applied as uniform as possible a standard to this aspect of the listing of events, thus ensuring some degree of internal consistency. The facts that our evaluation of the reliability of some of the events differs from hers, and that the order of the events in the two lists differs to some extent, demonstrate the considerable subjectivity of the judgments involved in these procedures - despite the fact that we have maintained close contact during the progress of this research. These inconsistencies could have been reduced if time had been available to record observations more objectively (by counting and measuring), but the inclusion in each chapter of tabulations of the relative abundances of each species in each sample does at least permit comparative evaluations of this nature.

The following comments are necessary to clarify certain aspects of the list of events (theoperids, artostrobiids, and amphipyndacids are omitted from the paragraphs below):

1) The following events (listed alphabetically by specific or subspecific name, or by generic name if not identified to species) occur above the level of Core 94-9, the youngest occurrence of radiolarians in the material collected on Leg 10. This list comprises tops of ranges of species present in Core 94-9, and bottoms of ranges of 
TABLE 1

Radiolarians from Site 86 (Upper Section)
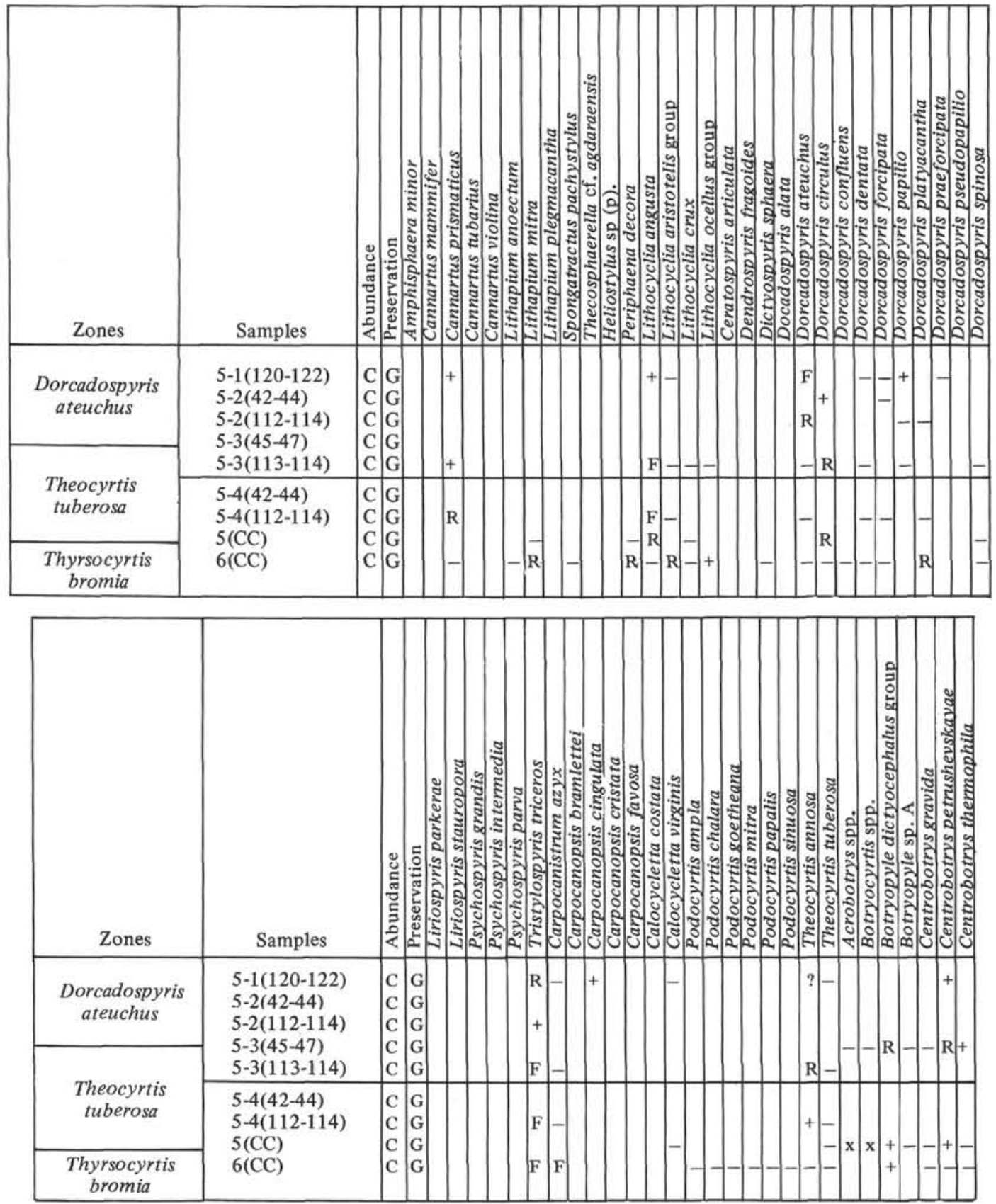

some species known from other evidence to occur in assemblages slightly younger than those of Core 94-9.

T Acrobotrys spp.

B Dorcadospyris alata

T Botryocyrtis spp.

$\mathrm{T}$ Carpocanopsis bramlettei

T Carpocanopsis cingulata

T Calocycletta costata

T Carpocanopsis cristata

T Dorcadospyris dentata

$\mathrm{T}$ Botryopyle dictyocephalus group

T Dorcadospyris forcipata

Psychospyris intermedia $\rightarrow P$. grandis
Cannartus mammiferus $\rightarrow$ C. laticonus

$\mathrm{T}$ Amphisphaera minor

Liriospyris stauropora $\rightarrow$ L. parkerae

T Centrobotrys thermophila

$\mathrm{T}$ Calocycletta virginis

2) Forms which occur in Core 86-8 (the oldest Cenozoic radiolarian sediments collected on Leg 10), and which may extend downward into older strata, are the following:

Spongomelissa adunca

Stylotrochus alveatus

Spongodiscus americanus

Astrosphaerin sp. A 
TABLE 2

Radiolarians from Site 86 (Lower Section)
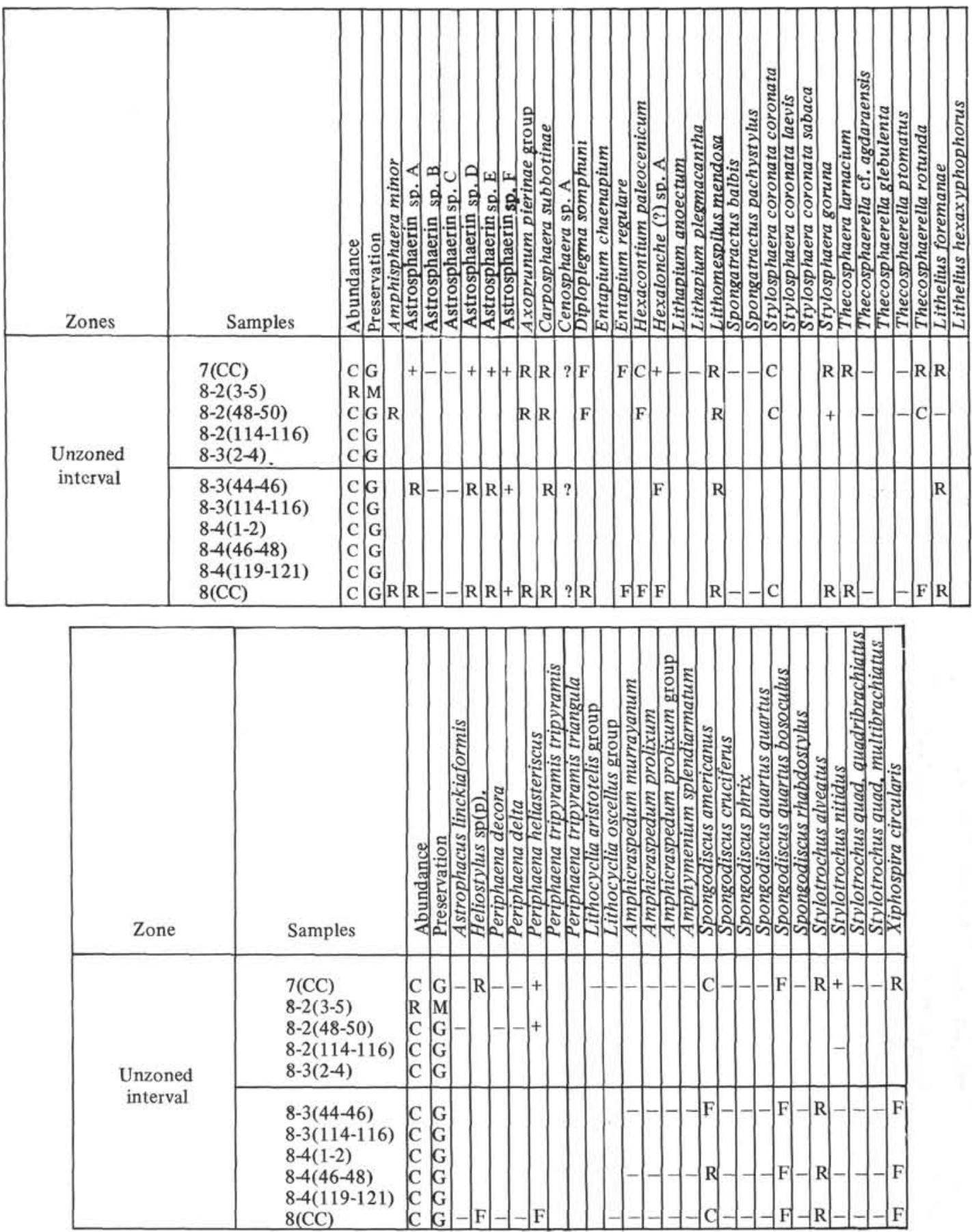

Astrosphaerin sp. D

Astrosphaerin sp. E

Astrosphaerin sp. F

Spongodiscus quartus bosoculus

Xiphospira circularis

Stylosphaera coronata coronata

Rhabdolithis ellida

Lithelius foremanae
Dendrospyris fragoides

Stylosphaera goruna

Periphaena heliasteriscus

Heliostylus sp(p).

Hexalonche sp. A

Thecosphaera larnacium

Lithomespilus mendosa

Amphisphaera minor 
Table 2 - Continued

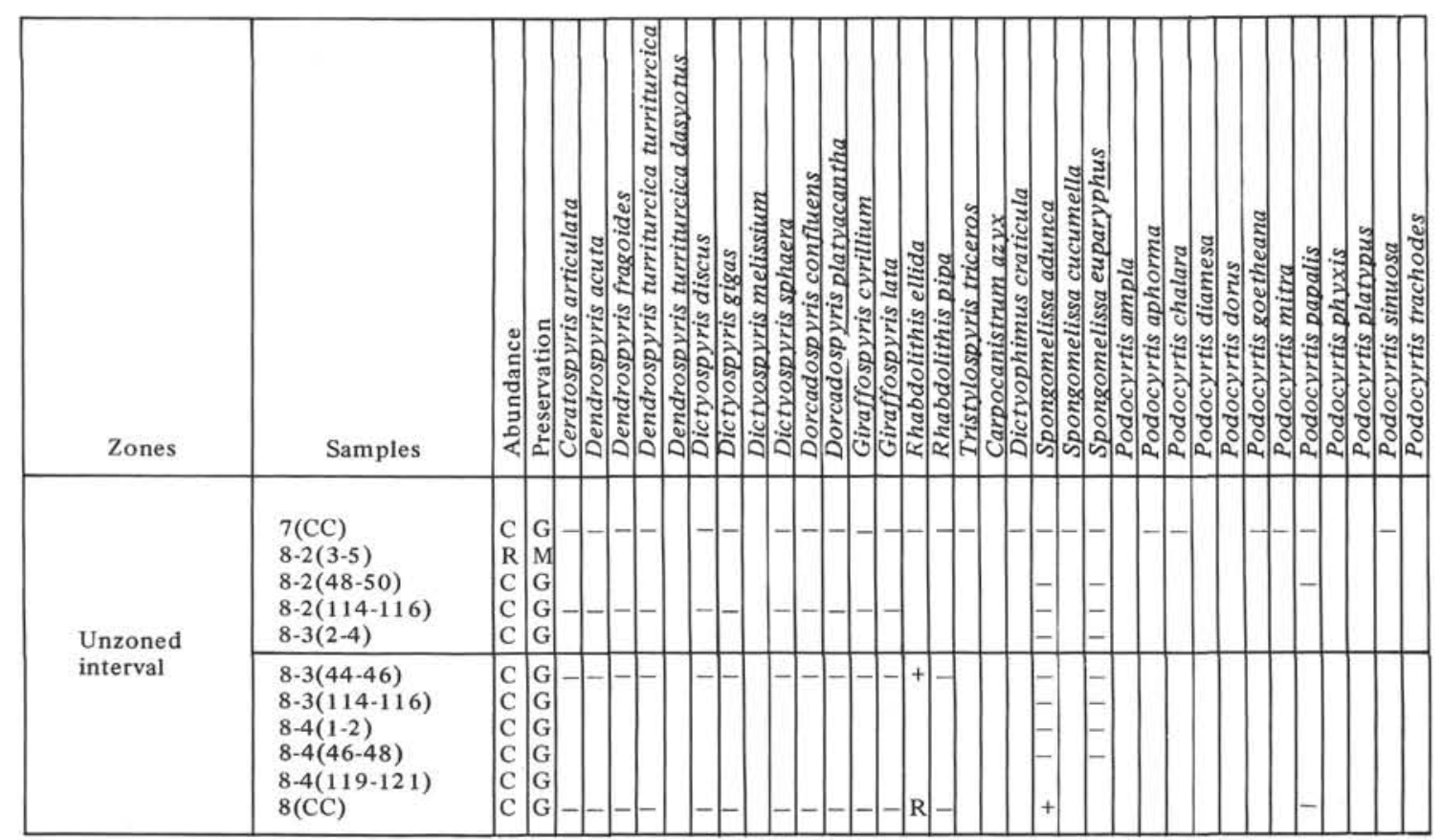

Hexacontium palaeocenicum

Axoprunum pierinae group

Entapium regulare

Thecosphaerella rotunda

Diploplegma somphum

Carposphaera subbotinae

3) Because the materials younger than middle Eocene have been treated in less detail than the older sediments, we have not determined the upper limits of the following forms which occur in Core 94-17 and apparently extend into younger strata.

Xiphospira circularis

Stylosphaera coronata coronata

Periphaena heliasteriscus

Lithelius hexaxyphophorus

Stylosphaera coronata laevis

Astrophacus linckiaformis

Axoprunum pierinae group

Rhabdolithis pipa

Thecosphaerella ptomatus

Entapium regulare

Spongodiscus rhabdostylus

Thecosphaerella rotunda

Amphymenium splendiarmatum

Periphaena tripyramis tripyramis

4) Some forms are not treated in sufficient detail to appear on the list of events, and for some we have determined only the earliest or latest occurrence. The following annotated list explains such cases.

T Dictyophimus craticula. The evolutionary lower limit of this species has been determined, but not its upper limit.

B Botryopyle dictyocephalus group. We have not determined the evolutionary origin of this group.
T Dendrospyris fragoides. Not included in the list of events because its latest occurrences are sparse and intermittent.

T Amphicraspedum murrayanum. As with the previous species, the latest occurrences are sparse and intermittent.

T Carposphaera subbotinae. The latest occurrences are sparse and intermittent.

5) The limits of the range of Carpocanistrum (?) azyx are not included in the events list because it is a last-minute addition to the species treated in this chapter.

As we pointed out in our report on the radiolarians from Leg 7, the list of radiolarian events serves two purposes: (1) it demonstrates the levels of correlation between the cored sequences at the various sites, together with the evidence (including its reliability) on which the correlations are based, and (2) it provides an intermediate step between the tabulation of species occurrences at the various sites, and the construction of a chart summarizing radiolarian ranges in the region.

Two range charts based on the Leg 10 material are presented, one for the Late Paleocene through part of Middle Eocene (Figure 5), and the other (including theoperids and artostrobiids) for part of the Middle Eocene through Early Miocene (Figure 6). Ranges of taxa are plotted against a vertical scale corresponding to depth below the sediment surface at Sites 94, 96, and 86. The placement of upper and lower limits of ranges is determined by their position in the list of radiolarian events, and thus some of them do not correspond precisely with the depth scale for the specific site indicated (if information judged to be more reliable is available from another Leg 10 site). Dashed upper and lower terminations of the lines indicating the ranges show the degree of uncertainty 
TABLE 3A

Radiolarians from Site 94 (Upper Section)

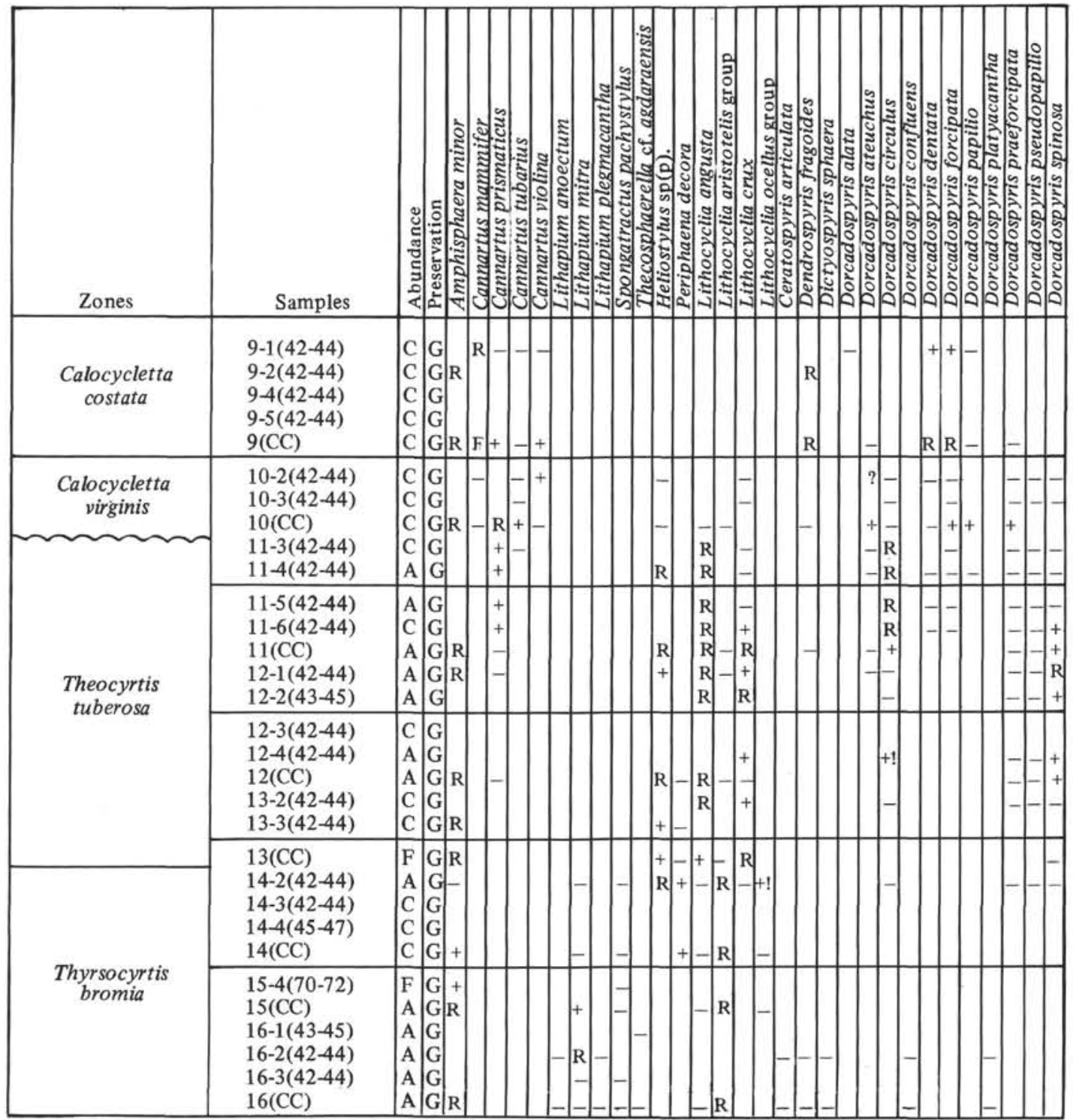

in the placement of the limits, and are due principally to gaps in the coring. Arrows indicate that ranges probably extend upward or downward from the limits shown. The abbreviations $m, e$ and $m e$ indicate whether limits are morphotypic, evolutionary, or morphotypic-evolutionary, respectively. Hachures are used to indicate the degree of uncertainty in placement of boundaries of radiolarian zones and epochal subdivisions. The range charts are a simplification of the information presented in the list of radiolarian events, and the reader is referred to Table 9 for more precise details.

\section{NEW INFORMATION OF PHYLOGENY}

The reports on radiolarians from Legs 4, 7 and 8 of the Deep Sea Drilling Project (Riedel and Sanfilippo, 1970; Riedel and Sanfilippo, 1971; Moore, 1971) have documented the continuing increase in our understanding of the phylogenetic development of some Cenozoic radiolarians. We here list advances made on the basis of the Leg 10 material.

Diploplegma somphum - Thecosphaerella ptomatus. It is suggested that the latter species may have evolved from the former.

Entapium chaenapium - Lithapium anoectum. There is some indication that $E$. chaenapium evolved into $L$. plegmacantha, which in turn gave rise to $L$. anoectum.

Axoprunum pierinae group - Spongatractus pachystylus lineage. Spongatractus balbis appears to be the intermediate member in this lineage.

Stylosphaera coronata coronata $-S$. coronata sabaca. The latter subspecies evidently evolved from the former.

Lithelius foremanae - $L$. hexaxyphophorus. There is an apparently continuous succession from the former species to the latter.

Periphaena heliasteriscus - P. tripyramis tripyramis. It seems likely that the latter species developed from the former. 
TABLE 3B

Radiolarians from Site 94 (Upper Section)

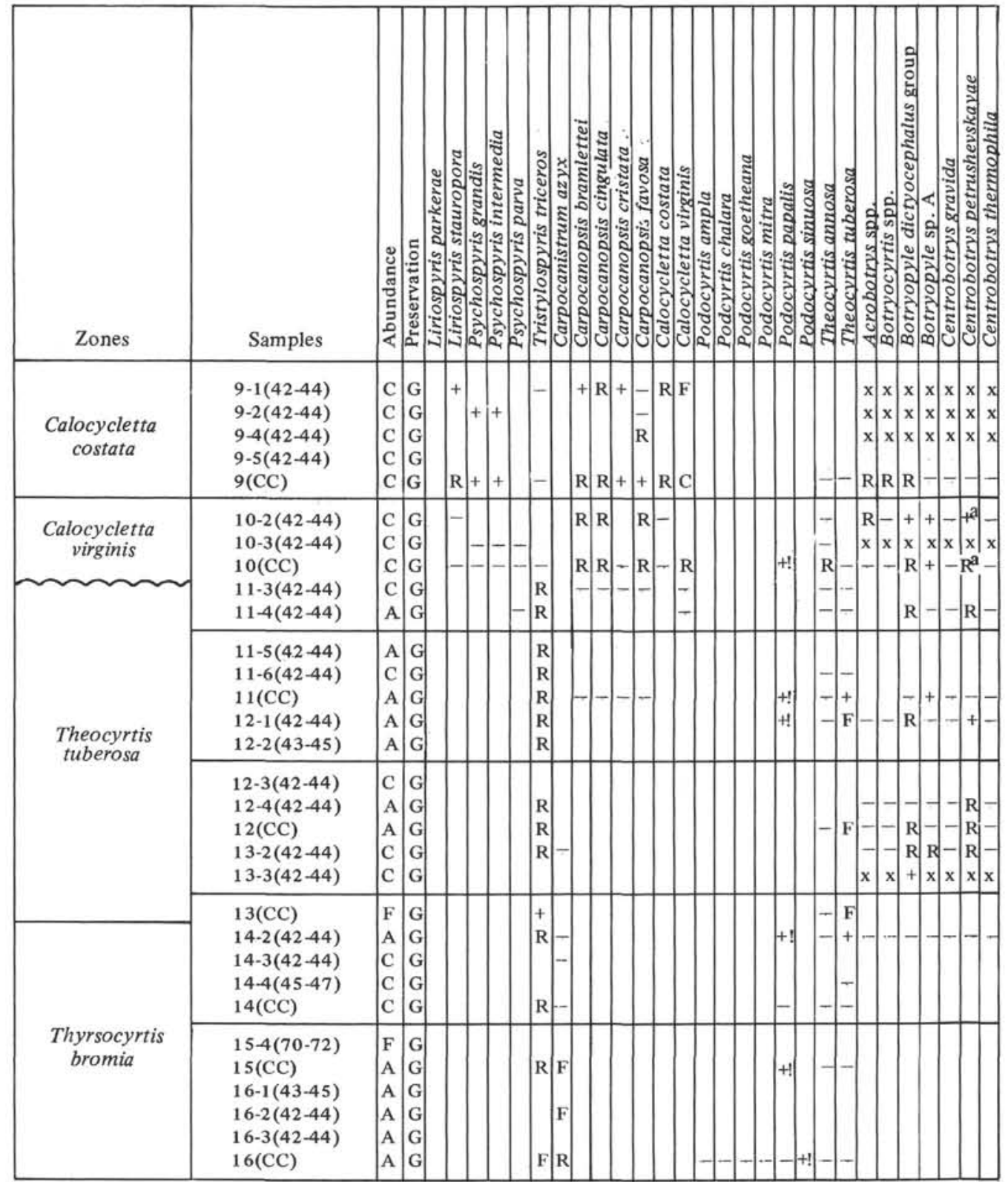

${ }^{\mathrm{a}}$ Centrobotrys with shell wall thinner than usual for $C$. petrushevskayae, and a strong tendency for the thorax to be closed distally.

Stylotrochus quadribrachiatus quadribrachiatus - S. quadribrachiatus multibrachiatus. The latter subspecies appears to have developed from the former.

Dendrospyris turriturcica turriturcica - D. turriturcica dasyotus. The latter subspecies evidently developed from the former.

Rhabdolithis ellida - $R$. pipa. The latter species evidently evolved from the former, and left no known descendants.

Spongomelissa adunca - $S$. euparyphus. Although few specimens are available, it appears that the latter species evolved from the former.

Podocyrtis papalis - P ampla lineage. Podocyrtis phyxis is described as the intermediate form between $P$. diames $a$ and $P$. ampla. Podocyrtis dorus and P. platypus are treated as offshoots from this evolutionary line.

Centrobotrys gravida - C. thermophila lineage. Centrobotrys petrushevskayae is the intermediate form in this series.

\section{SYSTEMATIC SECTION}

Genera are arranged alphabetically within families, and species alphabetically within genera. In assigning species to genera, we have placed greater weight on the probable relationship of a species to the type species of the genus than on the definition of the genus, since it seems inadvisable to take a generic definition seriously until it can be based on evolutionary relationships. Type species of genera are indicated, unless this information has been included in one of our recent papers.

In the synonymies of species that have previously been treated adequately, we here include only the reference to the original description and figure, the reference to the new combination if the generic name now used differs from that to which the species was originally assigned, and a reference to a paper defining the present concept of the species.

Type specimens will be deposited in the U.S. National Museum, Washington, D.C. 
TABLE 4A

Radiolarians from Site 94 (Lower Section)

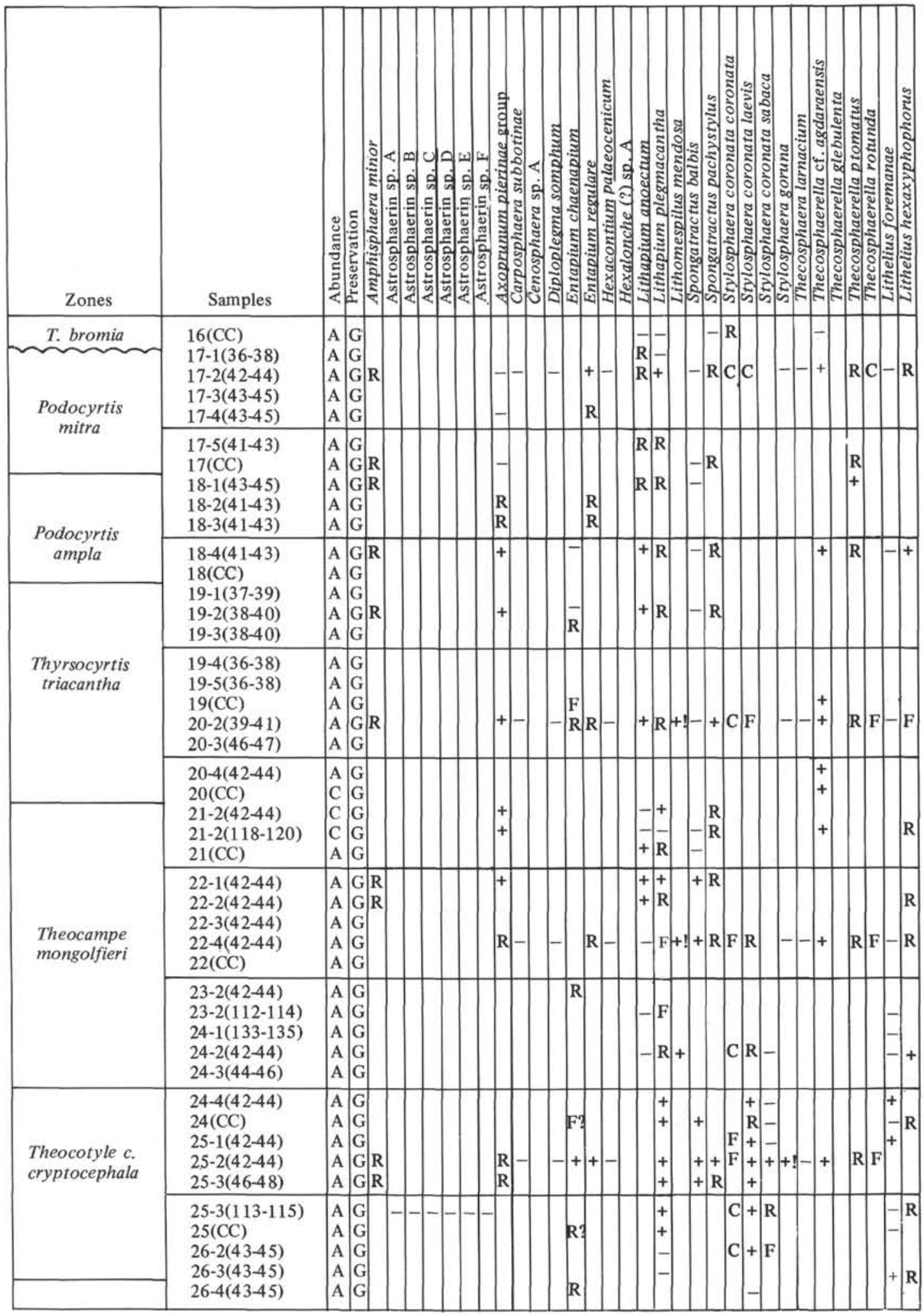

\section{8(1). Family COLLOSPHAERIDAE Müller, 1858}

The oldest members of this family that we have found in the Leg 10 material are in the Theocyrtis tuberosa Zone-a single specimen of Polysolenia in 94-12-1 (Plate 22, Figure 1), and in 94-12(CC) two specimens of a form with narrow intervening bars and short spines arising from the surface of these bars rather than from the pore margins (Plate 22, Figure 2). These occurrences are older than the earliest collosphaerids reported in the Leg 7 material, but are so sparse and intermittent that they do not shed much light on the origin of the family. The reported occurrence of a collosphaerid in the Bohemian Cretaceous (Perner, 1891) remains enigmatic. 
TABLE 4A - Continued

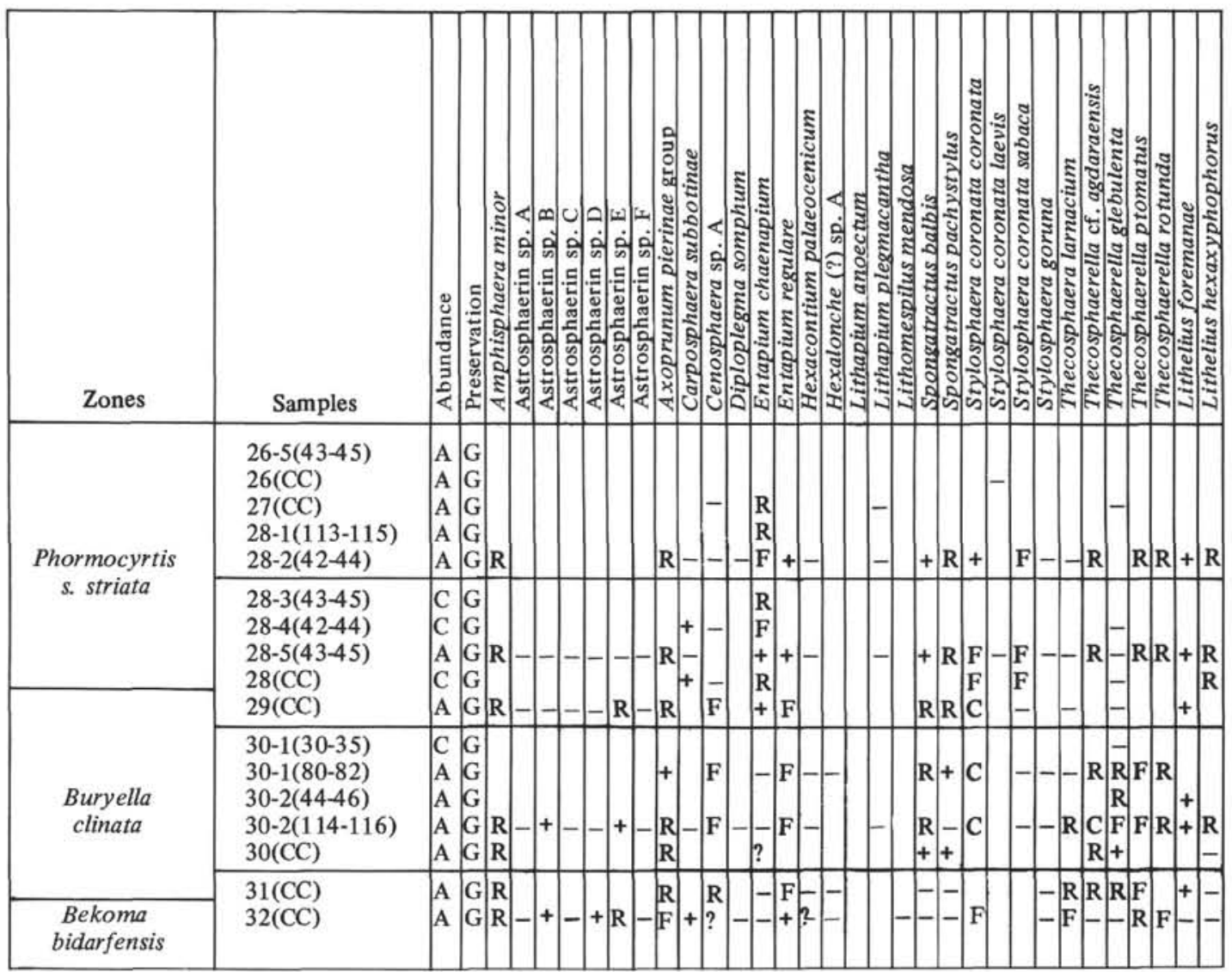

\section{8(2). Family ACTINOMMIDAE Haeckel 1862, Emend. Riedel 1967}

Although a considerable number of members of this family have been treated in the course of this investigation, we have in many cases not been able to ascertain their relationships and therefore many of the generic groupings are determined merely by convention or convenience.

Three specimens of saturnalins with spiny rings (one of them illustrated on Plate 22, Figure 3) were found in samples from Core 86-8.

\section{8(2)A. Genus AMPHISPHAERA Haeckel}

Amphisphaera Haeckel, 1881, p. 452. Type species (indicated by Campbell, 1954, p. 54) Amphisphaera neptunus Haeckel (1887, p. 142).

A genus that may be closely related, though its cortical shell is ellipsoidal, is Stuermeria Deflandre (1964, p. 3) - type species (by monotypy) Stuermeria hollandei Deflandre (1964, p. 3, pl. 1, figs. 12-14).

\section{8(2)Aa. Amphisphaera minor (Clark and Campbell)}

(Plate 1, Figures 1-5; Plate 22, Figure 4)

Stylosphaera minor Clark and Campbell, 1942, p. 27, pl. 5, figs. 1, 2, 2a, 12.

Description: Cortical shell wall of moderate thickness, with small circular pores (approximately $14-20$ on the half-equator) and minutely thorny surface. Delicate double medullary shell joined to cortical shell by two bars collinear with the polar spines, and other bars randomly distributed. Polar spines smoothly conical, usually longer than diameter of cortical shell.

Measurements (based on 30 st ecimens from 94-18-4, 94-28-5, 94-29(CC) and 94-30-1). Diameter (f cortical shell 95-175 $\mu$, of outer medullary shell $30-45 \mu$.

Remarks: This species is distinguish :d from the Axoprunum pierinae group by the spherical cortical shell, smaller pores, and constantly conical spines.
A. minor may be identical with Stylosphaera liostylus Ehrenberg $(1873$, p. $259 ; 1875$, pl. 25 , figs. 2, 3)-specimens that we have found in Eocene assemblages from Barbados have smaller pores than are shown in Ehrenberg's figure. Other generally similar species include Ellipsoxiphus cultum Borisenko (1960b, p. 225, pl. 2, fig. 2), Xiphosphaera irinae Lipman (1960, p. 75, pl. 10, fig. 6; pl. 13, fig. 6), and Xiphostylus minimus Mamedov (1969, p. 94, pl. 1, fig. 1).

\section{8(2)B. "ASTROSPHAERINS"}

Not enough is known of the relationships of forms hitherto known as astrosphaerids to judge whether they should appropriately be grouped as a subfamily of the Actinommidae Haeckel (in the sense of Riedel, 1967). However, the following unnamed forms, fragmentarily represented in the cores, appear to be related to one another, and to the astrosphaerids, and may therefore be referred to as "astrosphaerins" until more is known of their structure and relationships. We have distinguished six forms of radial spines, but know little of the shape, structure and number of concentric shells.

\section{8(2)Ba. Astrosphaerin sp. A}

\section{(Plate 5, Figures 1,2; Plate 22, Figure 5)}

The external portion of the main radial spines is heavy, subcylindrical to slightly swollen, terminating distally in three short, divergent thorns (rather like a clove, the flower bud of Syzygium aromaticum). The lattice-shell is formed of large, irregular meshes separated by heavy cylindrical bars, and the radial spines (always broken short) continue inside it as three-bladed bars. Some fragments of the coarse lattice-shell also bear shorter, simple conical spines.

In Core 96-3, which is above the range of this species, occur spines (Plate 22, Figure 6) rather similar to astrosphaerin sp. A but terminating proximally in a small-pored lattice-shell, rather than giving rise to a coarse shell and continuing as a bladed bar. 
TABLE 4B

Radiolarians from Site 94 (Lower Section)

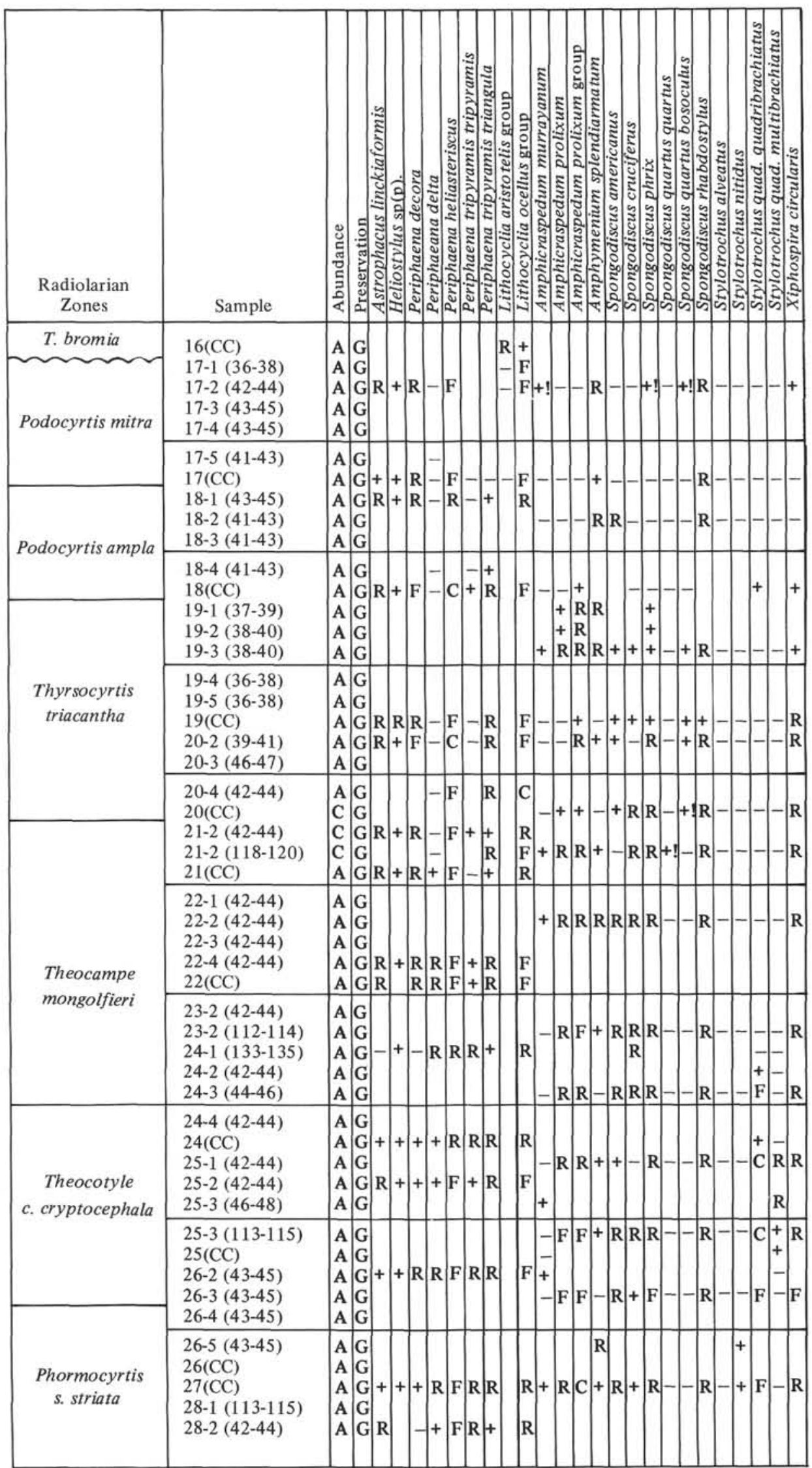


TABLE 4B - Continued

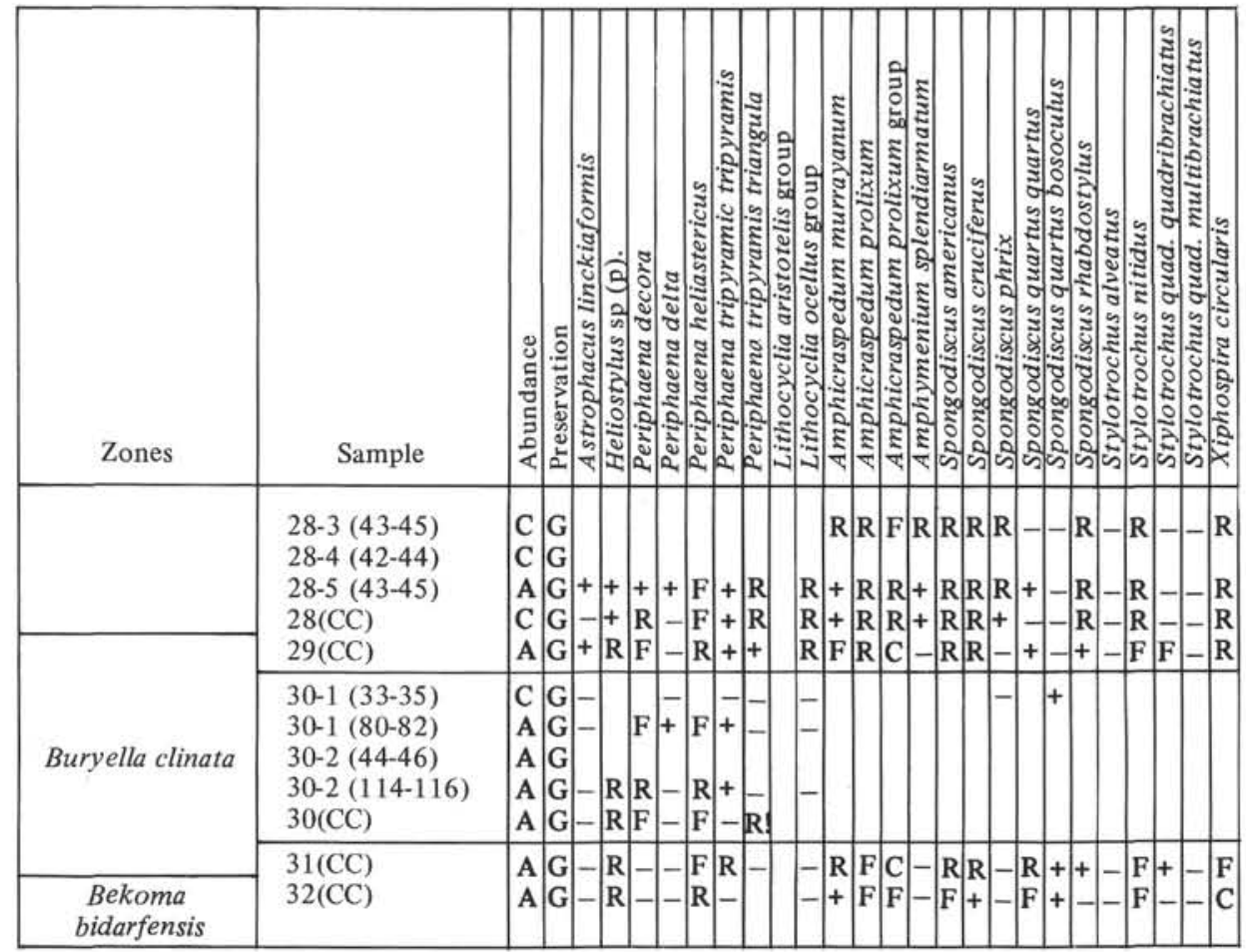

8(2)Bb. Astrosphaerin sp. B

(Plate 5, Figures 3,4; Plate 22, Figure 7)

Similar to astrosphaerin sp. A, and evidently very closely related, but with the distal portion of the main radial spines minutely and irregularly thorny, rather than terminally trifurcate, and with these spines gradually tapering rather than swollen.

$8(2) B c$. Astrosphaerin sp. C

(Plate 5, Figures 5,6; Plate 22, Figure 8)

The external part of the radial spine is subcylindrical, gradually tapering, with minute, irregularly disposed thorns distally (similar to those of astrosphaerin sp. B). Proximally, the radial spine is threebladed, and from it arise two whorls of three long, tapering spinules each (generally not arising at exactly the same level), and one or two small-pored lattice-shells.

8(2)Bd. Astrosphaerin sp. D

(Plate 6, Figures 1, 2; Plate 22, Figure 9)

A long, three-bladed spine, terminating distally in a conical thorn surrounded by a whorl of three long, downwardly-curved, tapering spinules lying approximately in a plane at right angles to the axis of the spine. These spinules in this and the following two species commonly terminate in a spathilla (Plate 22, Figures 10,11 ) such as those described by Haeckel (1887) in Octodendron spathillatum, by Mast (1910) in Heterospongus varians, by Hollande and Enjumet (1960) in Octodendron hamuliferum, and by many authors in phaeodarians. The blades of the spine are sometimes thorny, and sometimes spirally twisted.

In assemblages containing this and the following species are fragments of lattice-shells, sometimes filled with delicate, irregular, loosely anastomosing filaments (Plate 22, Figure 12), which may represent the central structure of these species.

8(2)Be. Astrosphaerin sp. E

(Plate 6, Figures 3-6; Plate 23, Figure 1)

Similar to astrosphaerin sp. D, but the conical thorn beyond the whorl of spinules is either absent or represented by a small knob or very short thorn.
8(2)Bf. Astrosphaerin sp. F

(Plate 6, Figures 7, 8; Plate 23, Figure 2)

The three distal spinules on the bladed spine differ from those of the preceding two species in being flattened and curved (all in the same sense), so that the structure resembles a three-bladed propeller. The long, three-bladed spine is probably similar to that of the two preceding species, but this species is difficult to recognize when that spine is long and the whorl consequently viewed from the side.

\section{8(2)C. Genus AXOPRUNUM Haeckel}

Axoprunum Haeckel, 1887, p. 298. Type species (by monotypy) Axoprunum stauraxonium Haeckel (1887, p. 298, pl. 48, fig. 4).

\section{8(2)Ca. Axoprunum pierinae (Clark and Campbell) group}

(Plate 1, Figures 6-12; Plate 23, Figure 3)

Includes Lithatractus pierinae Clark and Campbell, 1942, p. 34, pl. 5, fig. 25 and Xiphatractus mirificus Mamedov, 1969, p. 100, pl. 1, figs. 3, $3 \mathrm{a}$.

Description: Cortical shell slightly to markedly ellipsoidal, of variable thickness, with subcircular pores of variable size (approximately $10-16$ on the half-equator). Double medullary shell (the outer one lenticular or spherical) joined to cortical shell by strong bars in the equatorial plane or zone, and in some specimens also by two bars collinear with the polar spines. Polar spines very variable in size and formin some specimens bladed, in others conical.

Measurements (based on 25 specimens from 94-18-4; 94-28-5; 94-29 (CC); 94-30-1; and 94-32 (CC)). Major diameter of cortical shell $120-195 \mu$, its minor diameter $95-185 \mu$. Maximum diameter of outer medullary shell $30-50 \mu$. Length of polar spines $30-250 \mu$.

Remarks: This group is used to embrace all ellipsoidal forms with two polar spines occurring in the early Eocene and Late Paleocene assemblages, which are not treated separately. More than one species may be included, but we have not been able to separate them satisfactorily.

\section{8(2)D. Genus CANNARTUS Haeckel}

Cannartus Haeckel, 1881, p. 462; emend. Riedel, 1971, p. 652. 
TABLE 4C

Radiolarians from Site 94 (Lower Section)

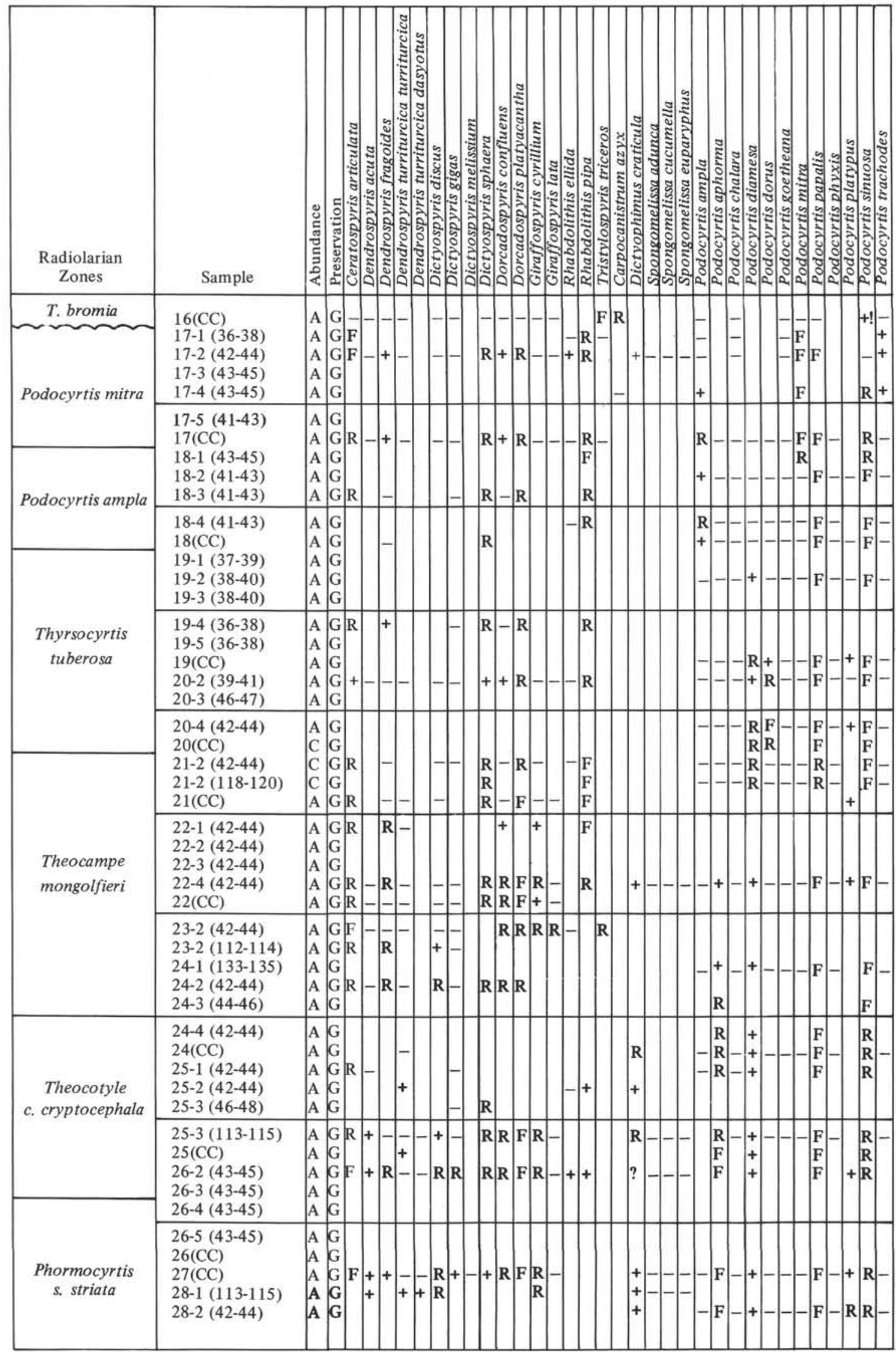


TABLE 4C - Continued

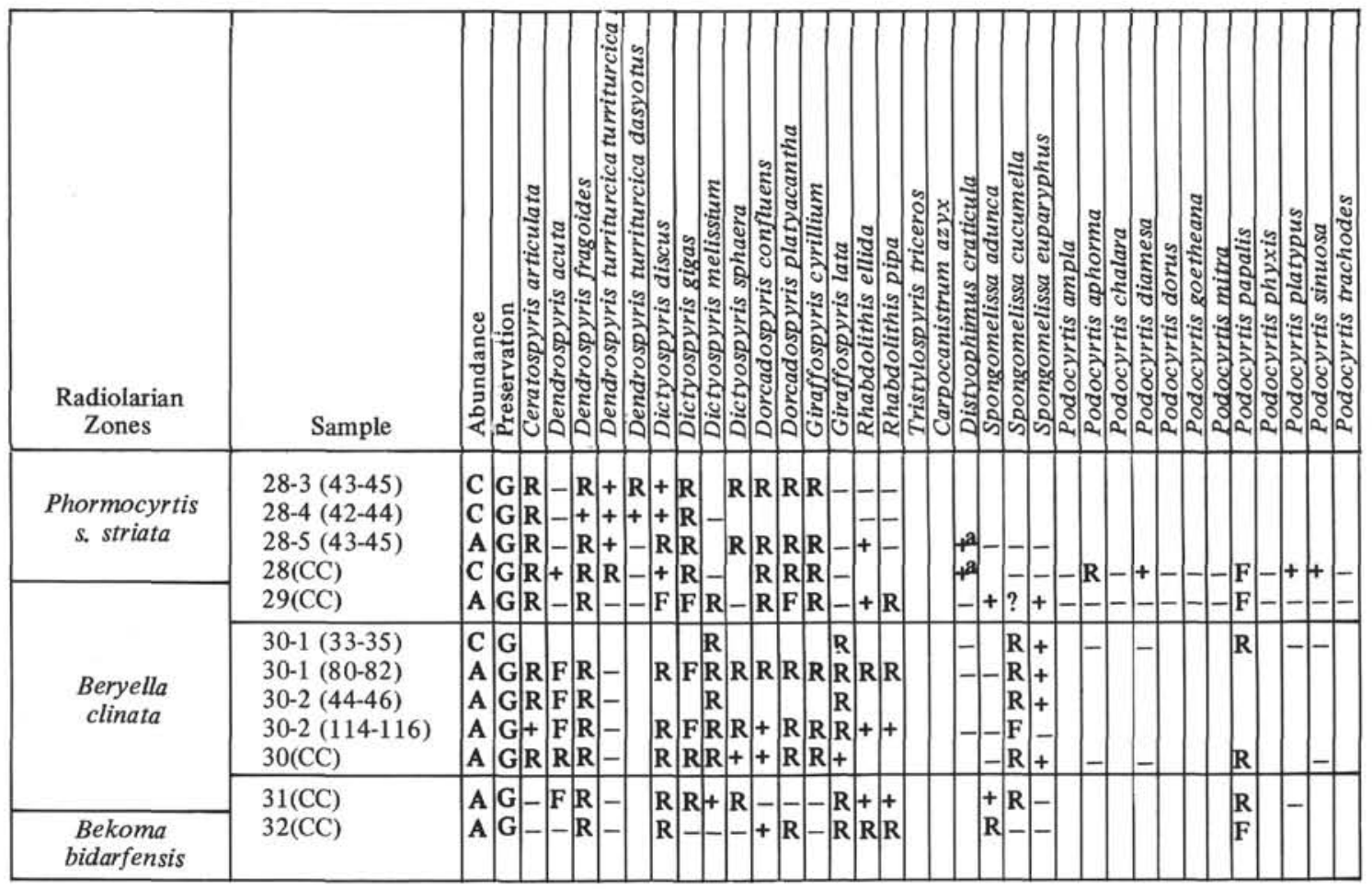

${ }^{\mathrm{a}}$ In these assemblages, typical Dictyophimus craticula is outnumbered by the apparently ancestral form described in the discussion of the Family Plagoniidae.

\section{8(2)Da. Cannartus mammiferus (Haeckel)}

Cannartidium mammiferum Haeckel, 1887, p. 375, pl. 39, fig. 16. Cannartus mammiferus (Haeckel), Riedel, 1959, p. 291, pl. 1, fig. 4.

\section{8(2)Db. Cannartus prismaticus (Haeckel)}

Pipettella prismatica Haeckel, 1887, p. 305, pl. 39, fig. 6; Riedel, 1959, p. 287 , pl. 1, fig. 1.

Cannartus prismaticus (Haeckel), Riedel and Sanfilippo, 1970, p. 520, pl. 15 , fig. 1 ; 1971 , p. 1588 , pl. 2C, figs. 11-13, pl. 4, fig. 5 .

\section{8(2)Dc. Cannartus tubarius (Haeckel)}

Pipettaria tubaria Haeckel, 1887, p. 339, pl. 39, fig. 15; Riedel, 1959, p. 289, pl. 1, fig. 2.

Cannartus tubarius (Haeckel), Riedel and Sanfilippo, 1970, p. 520, pl. 15, fig. 2.

\section{8(2)Dd. Cannartus violina Haeckel}

Cannartus violina Haeckel, 1887, p. 358, pl. 39, fig. 10; Riedel, 1959, p. 290, pl. 1, fig. 3.

\section{8(2)E. Genus CARPOSPHAERA Haeckel}

Carposphaera Haeckel, 1881, p. 451. Frizzell and Middour (1951, p. 10) attempted to fix Carposphaera melitomma Haeckel, 1887, as the type species, but that is not possible because a number of species were described in this genus by Rüst in 1885 .

\section{$8(2) \mathrm{Ea}$. Carposphaera subbotinae (Borisenko)}

(Plate 4, Figure 3; Plate 23, Figures 4,5)

Cenosphaera subbotinae Borisenko, 1958, p. 85, pl. 5, figs. 5-7.

Description: Cortical shell spherical, thin-walled, with thorny surface and circular to subcircular pores regular to irregular in size and arrangement. Medullary shell large, generally similar to cortical shell but with pores about 30 per cent smaller in diameter, attached to the cortical shell by numerous (perhaps 30-40) radial bars which do not extend beyond the shell surface.
Measurements (based on 15 specimens from 86-7, CC; 86-8-3; 86-8-4; and 86-8, CC). Diameter of cortical shell $180-240 \mu$, of medullary shell $105-130 \mu$. Distance between centers of pores of cortical shell $15-22.5 \mu$.

Remarks: This species is distinguished by its large medullary shell. There is some similarity to Haliomma entactinia Ehrenberg (1873, p. $235 ; 1875$, pl. 26, fig. 4), but we have not been able to determine whether the two species are identical.

\section{8(2)F. Genus CENOSPHAERA Ehrenberg}

Cenosphaera Ehrenberg, 1854a, p. 237. Type species (by monotypy)

Cenosphaera plutonis Ehrenberg (1854a, p. 241; 1854b, pl. 35B, fig. 20).

It seems likely that Monosphaera Shrubsole (1889, p. 123 - type species, by monotypy, Monosphaera toliapica Shrubsole, 1889, p. 123, fig. 11 ) is a synonym of Cenosphaera.

8(2)Fa. Cenosphaera sp. A (Plate 4, Figure 4; Plate 23, Figure 6)

Description: Shell single, thick-walled, small, spherical, with minutely thorny surface and subcircular to circular pores rather regular in size and arrangement (distance between pore centers 8-15 $\mu$ ).

Measurements (based on 20 specimens from 94-28-2, 94-29, CC and 94-30-2). Diameter of shell 70-95 .

Remarks: The principal reason for describing this unnamed species is the fact that small, simple spheres of this size occur rather frequently over a restricted range in the sequence examined. A rather similar form from the Californian Eocene has been described as Cenosphaera megachile by Clark and Campbell (1945, p. 5, pl. 1, fig. 1). Other, larger single spherical shells occur together with this form and in older and younger assemblages, but may represent incompletely developed or poorly preserved individuals of species having a medullary shell. Because of the uncertain relationships of these simple shells, we have been unable to identify them specifically. 
TABLE 5A

Radiolarians from Site 95 (Upper Section)

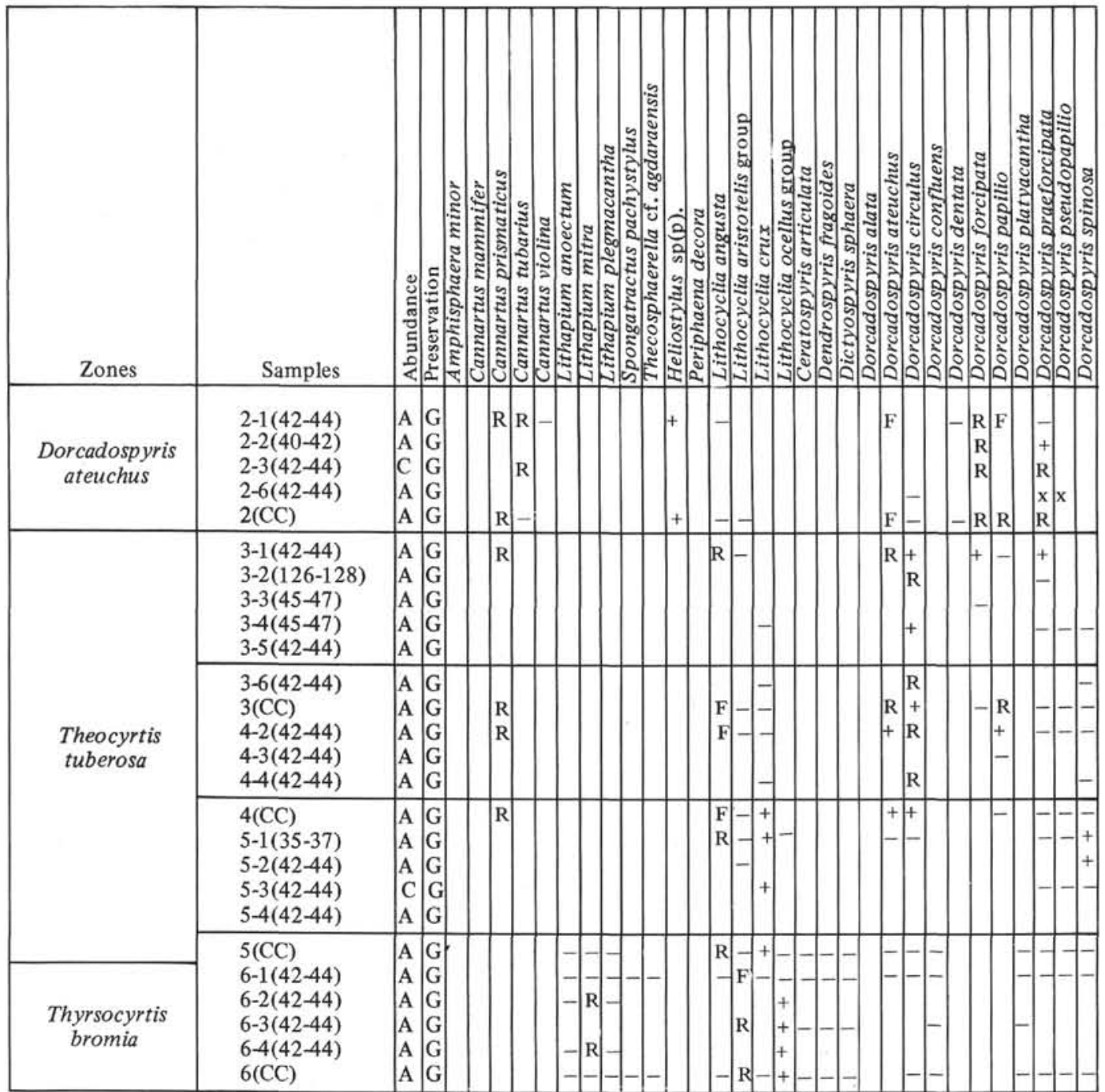

Similar, but larger, species described in the literature on Paleogene radiolarians include Cenosphaera mitgarzi Lipman (1950, p. 54, pl. 1, fig. 2) and C. micra Borisenko (1960a, p. 200, pl. 1, figs. 1, 2).

\section{8(2)G. Genus DIPLOPLEGMA Hinde}

Diploplegma Hinde, 1890 , p. 48 . Type species (by monotypy) Diploplegma cinctum Hinde (1890, p. 48, pl. 3, fig. 10).

It seems unlikely that the species described below is closely related to the Paleozoic type species, even though both have spongy cortical and medullary shells.

\section{8(2)Ga. Diploplegma somphum Sanfilippo and \\ Riedel, new species}

(Plate 4, Figure 5; Plate 23, Figures 7, 8)

Description: Cortical shell spherical, with a thick spongy wall of rather coarse meshes, thorny surface, and a narrow pylome generally surrounded by differentiated thorns. Medullary shell spongy, directly attached to the cortical shell wall, in a position bearing no constant relationship to the location of the pylome.

Measurements (based on 30 specimens from 86-7, CC and 86-8-3). Diameter of cortical shell $185-255 \mu$, of medullary shell (as seen darkly through the cortical shell) approximately $20-55 \mu$.

Remarks: It seems possible that $D$. somphum gave rise to Thecosphaerella ptomatus, since the upper limit of its range essentially coincides with the lower limit of the range of the latter, and these are the only two species present with the medullary shell directly attached to the cortical shell.

The specific name is derived from the Greek adjective somphos (porous, spongy).

8(2)H. Genus ENTAPIUM Sanfilippo and Riedel, new genus

Type species Entapium regulare Sanfilippo and Riedel, new species.

Definition: This genus differs from all others with a spherical cortical shell in possessing a single medullary shell which is pyriform, or at least has pores of different size at two poles. Bladed external spines are usually present on the cortical shell.

The name is derived from the Greek entos (within) and apion (pear), and is neuter.

\section{8(2)Ha. Entapium chaenapium Sanfilippo and \\ Riedel, new species}

(Plate 3, Figure 3; Plate 23, Figures 9-12)

Description: Spherical cortical shell with minutely thorny wall of moderate thickness, perforated by subcircular pores rather variable in size (approximately $11-14$ on the half-equator), and bearing approximately 4 bladed spines. Medullary shell pyriform, delicate, with relatively large pores, connected to the cortical shell by about $5-7$ bladed bars, some of which (including one from the narrow end of the medullary shell) are collinear with the external spines. Practically all specimens 
TABLE 5B

Radiolarians from Site 95 (Upper Section)

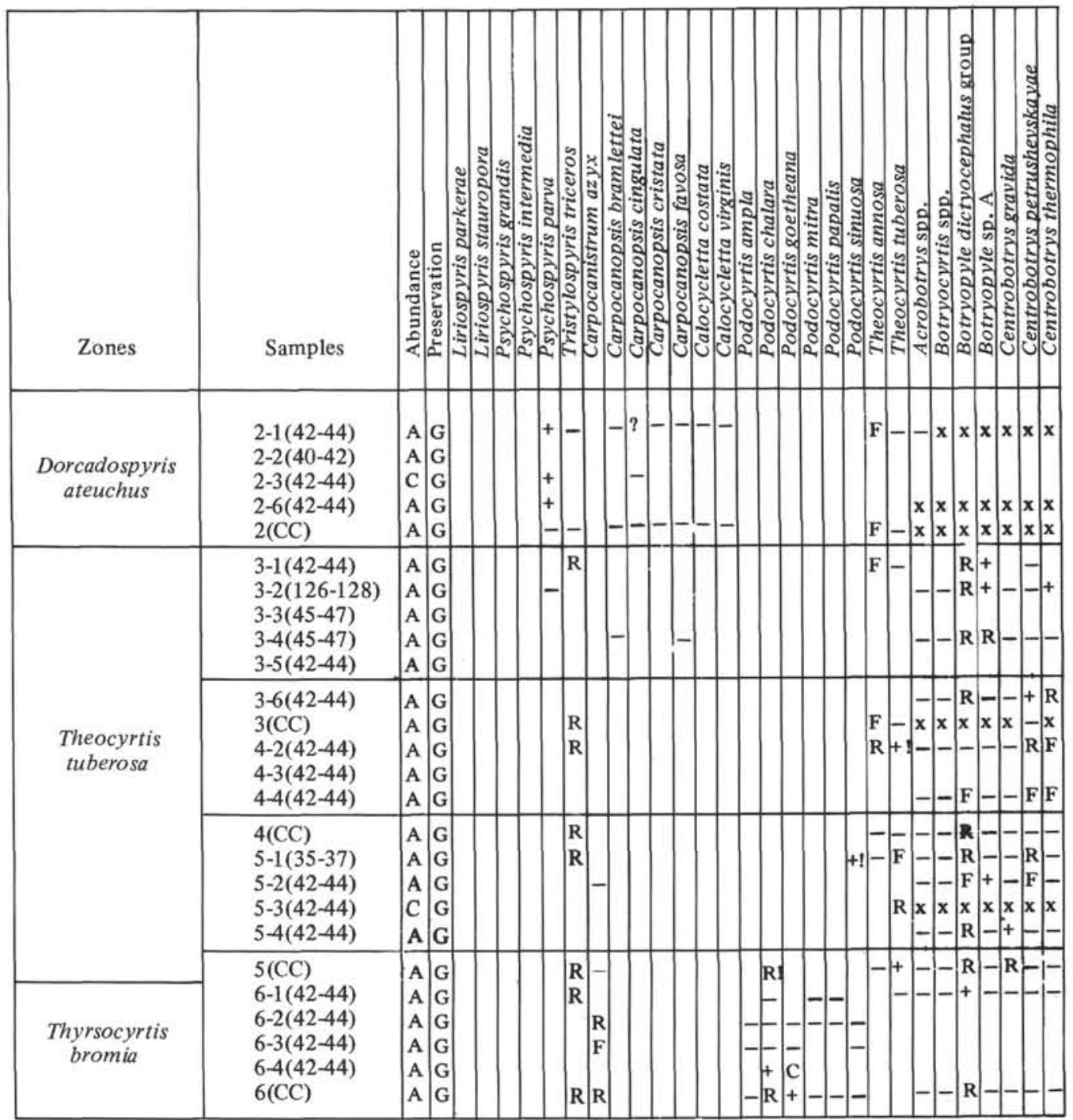

from the later part of the range of this species, and some from earlier assemblages, have an opening in the medullary shell at the end opposite its conical part. In the vicinity of this opening, bars connecting the medullary with the cortical shell are not bladed but thin, as if atrophying.

Measurements (based on 20 specimens from 94-22-4 and 94-28-2). Diameter of cortical shell 105-150 $\mu$. Width of medullary shell $37-50 \mu$.

Remarks: Cooccurring with this species, and in slightly older and younger assemblages, are at least two other generally similar forms with pyriform medullary shells. One of these (Entapium regulare) has a larger number of smaller pores on the cortical shell (approximately 22-26 on the half-equator), and in another the pores of the cortical shell are rosette-shaped. Thus the characters distinguishing these forms are not very prominent, and our principal reason for treating this species is the possibility that it may be ancestral to Lithapium plegmacantha (see discussion under that heading).

The specific name is derived from the Greek chaino (open) and apion (pear), and is used as a noun in apposition.

\section{$8(2) \mathrm{Hb}$. Entapium regulare Sanfilippo and \\ Riedel, new species}

(Plate 1, Figures 10-19; Plate 24, Figures 1-3)

Description: Cortical shell spherical, of very variable diameter, moderately thick-walled, with circular pores (approximately $7.5-12.5 \mu$ between centers, and $22-26$ pores on the half-equator) and minutely thorny surface. Medullary shell single, delicate, pyriform, attached to the cortical shell by at least six strong, bladed bars, some of which extend from the surface as free spines.

Measurements (based on 30 specimens from 86-8 CC; 94-29, CC; and 96-3-6). Diameter of cortical shell $130-245 \mu$. Width of medullary shell $30-45 \mu$.

Remarks: This species is distinguished from others with a pyriform medullary shell by the pores of the cortical shell being small, rather regular in size and arrangement, and not rosette-shaped.

\section{8(2)I. Genus HEXACONTIUM Haeckel}

Hexacontium Haeckel, 1881, p. 452. Type species (indicated by Campbell, 1954, p. 60) Hexacontium phaenaxonium Haeckel (1887, p. 192).

\section{8(2)Ia. Hexacontium palaeocenicum Sanfilippo and Riedel, new species (Plate 4, Figure 2; Plate 24, Figure 4)}

Description: Spherical cortical shell thick-walled, with thorny surface and hexagonally framed, rosette-shaped pores rather regular in size and arrangement (distance between centers approximately 11-17.5 $\mu$ ). Six external spines mutually perpendicular, short, heavy, pronouncedly bladed, especially near the bases where the blades are continuous with 
TABLE 6A

Radiolarians from Site 95 (lower section)

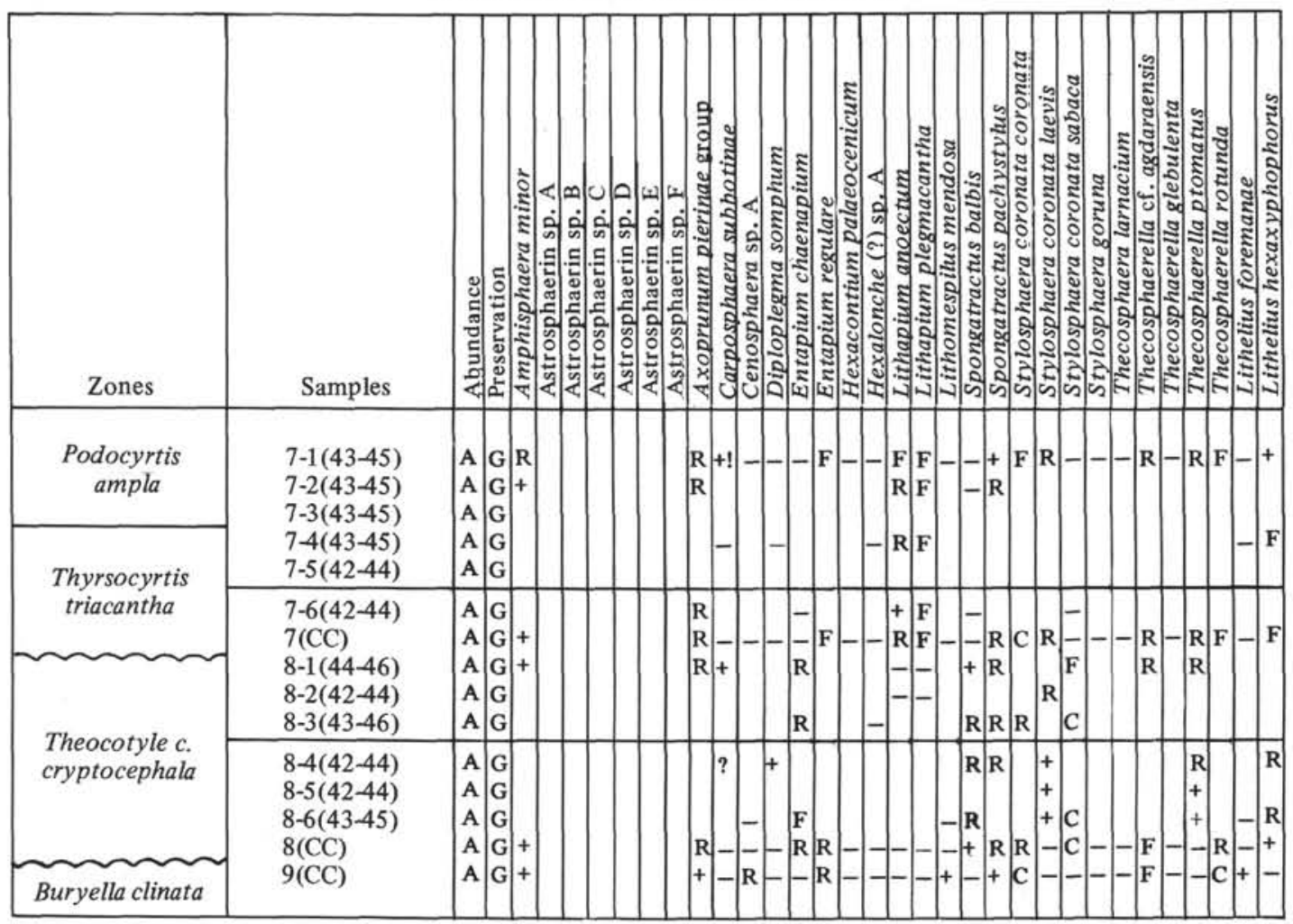

TABLE 6B

Radiolarians from Site 95 (Lower Section)

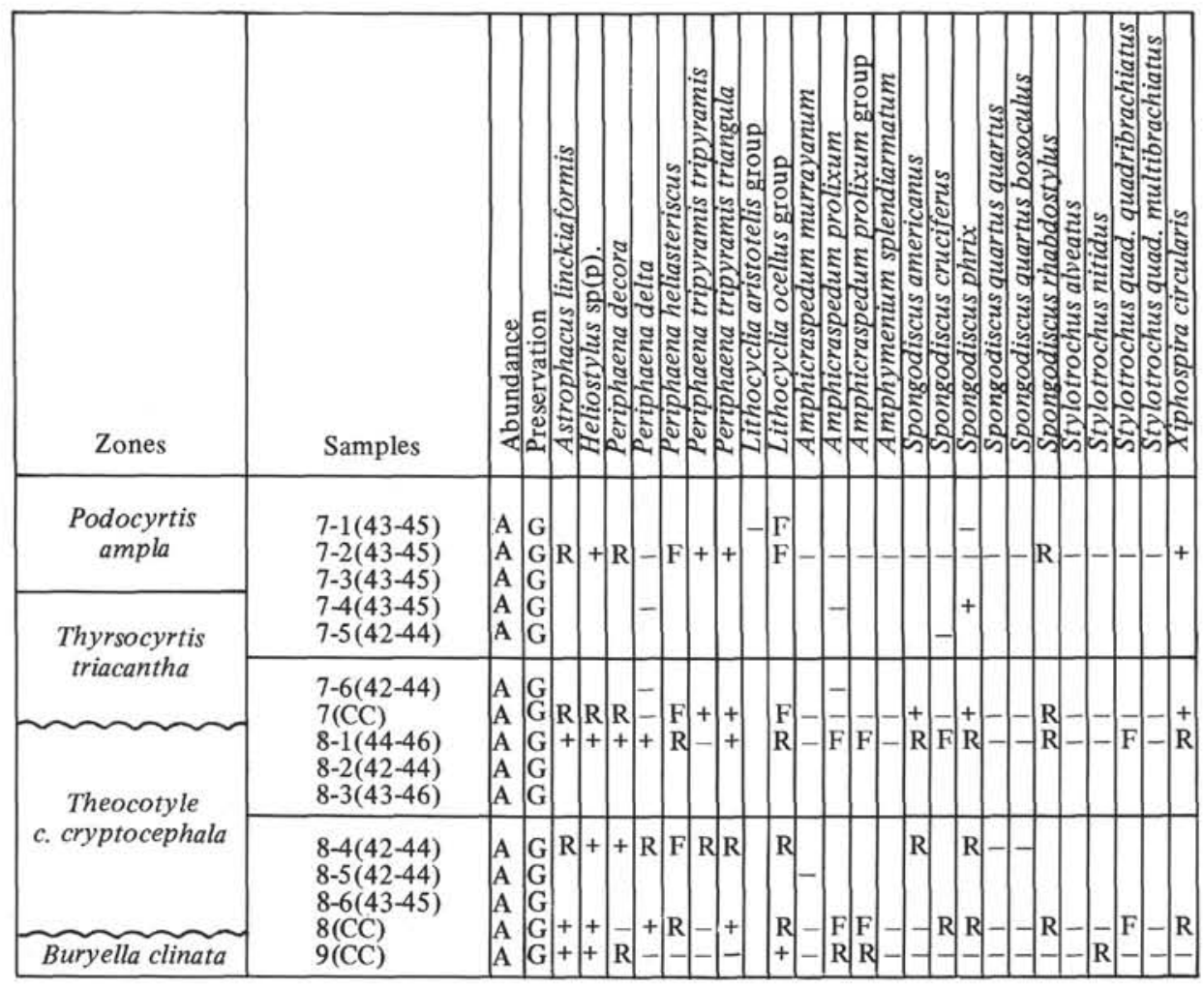


TABLE 6C

Radiolarians from Site 95 (Lower Section)

\begin{tabular}{|c|c|c|c|c|c|c|c|c|c|c|c|c|c|c|c|c|c|c|c|c|c|c|c|}
\hline Zones & Samples & 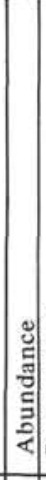 & | & & 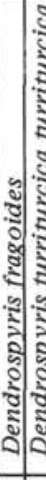 & & & & : & 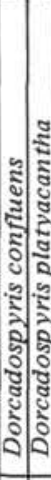 & 絇 & 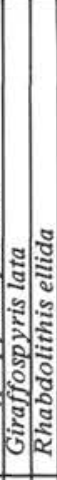 & 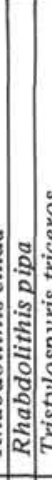 & 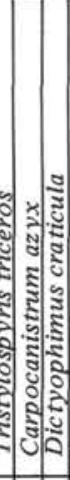 & 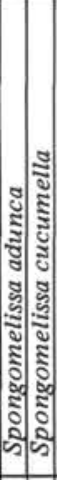 & 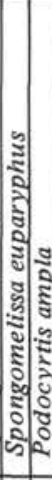 & 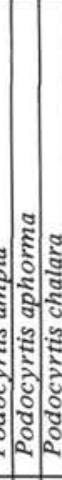 & 5 & & 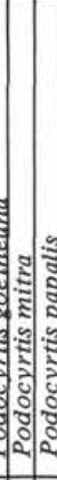 & $2=$ & 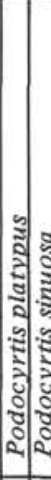 & : \\
\hline $\begin{array}{l}\text { Podocyrtis } \\
\text { ampla }\end{array}$ & $\begin{array}{l}7-1(43-45) \\
7-2(43-45) \\
7-3(43-45) \\
7-4(43-45) \\
7-5(42-44) \\
\end{array}$ & $\begin{array}{l}\mathrm{A} \\
\mathrm{A} \\
\mathrm{A} \\
\mathrm{A} \\
\mathrm{A}\end{array}$ & $\begin{array}{l}G \\
G \\
G \\
G \\
G\end{array}$ & & $\mathrm{R}-$ & & $-1+$ & & $\begin{array}{l}\mathrm{R} \\
\mathrm{R} \\
\mathrm{R}\end{array}$ & $+R$ & - & - & $\mathrm{R}$ & & & $\begin{array}{l}\mathrm{R} \\
+ \\
- \\
-\end{array}$ & & + & $\begin{array}{l}- \\
- \\
+\end{array}$ & $\begin{array}{l}+ \\
+R \\
-\end{array}$ & - & $\begin{array}{l}-F \\
F \\
F \\
F\end{array}$ & F \\
\hline triacantha & $\begin{array}{l}7-6(42-44) \\
7(\mathrm{CC}) \\
8-1(44-46) \\
8-2(42-44) \\
8-3(43-46) \\
\end{array}$ & $\begin{array}{l}\mathrm{A} \\
\mathrm{A} \\
\mathrm{A} \\
\mathrm{A} \\
\mathrm{A}\end{array}$ & \begin{tabular}{l|l}
$G$ & $R$ \\
$G$ & + \\
$G$ & $R$ \\
$G$ & $R$ \\
$G$ & \\
\end{tabular} & - & $\begin{array}{l}- \\
+ \\
+ \\
+ \\
+\end{array}$ & & \begin{tabular}{l|l}
- & + \\
- & - \\
+ & -
\end{tabular} & & $\begin{array}{l}\mathrm{R} \\
\mathrm{R} \\
\mathrm{R} \\
\mathrm{R}\end{array}$ & \begin{tabular}{|l|l}
+ & $\mathrm{R}$ \\
$\mathrm{R}$ & $\mathrm{R}$ \\
$\mathrm{R}$ & $\mathrm{R}$ \\
$\mathrm{R}$ & $\mathrm{R}$
\end{tabular} & \begin{tabular}{|l|l|}
$\mathrm{R}$ & - \\
$\mathrm{R}$ & $\mathrm{R}$ \\
$\mathrm{R}$ & $\mathrm{R}$ \\
\end{tabular} & & $\begin{array}{l}\mathrm{R} \\
+ \\
+ \\
+\end{array}$ & & & & & + & + & $\begin{array}{l}\mathrm{F} \\
\mathrm{F}\end{array}$ & & $\begin{array}{l}-F \\
+F\end{array}$ & \\
\hline 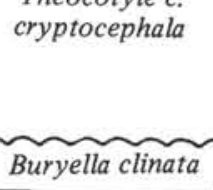 & $\begin{array}{l}8-4(42-44) \\
8-5(42-44) \\
8-6(43-45) \\
8(C C) \\
9(C C)\end{array}$ & \begin{tabular}{|l|}
$\mathrm{A}$ \\
$\mathrm{A}$ \\
$\mathrm{A}$ \\
$\mathrm{A}$ \\
$\mathrm{A}$
\end{tabular} & \begin{tabular}{l|l}
$G$ & $R$ \\
$G$ & \\
$G$ & \\
$G$ & $R$ \\
$G$ & +
\end{tabular} & + & $\mathrm{R}-$ & & $\mathrm{R}$ & & $\mathrm{R}$ & $\mathrm{R} / \mathrm{R}$ & $\begin{array}{l}\mathrm{R} \\
+\end{array}$ & - & $\begin{array}{l}+ \\
+\end{array}$ & & & & $\mathrm{F}-$ & $R$ & & $-\mathrm{F}$ & $\begin{array}{l}F \\
R\end{array}$ & $+R$ & $\mathbf{R}$ \\
\hline
\end{tabular}

TABLE 7A

Radiolarians from Site 96 (Upper Section)

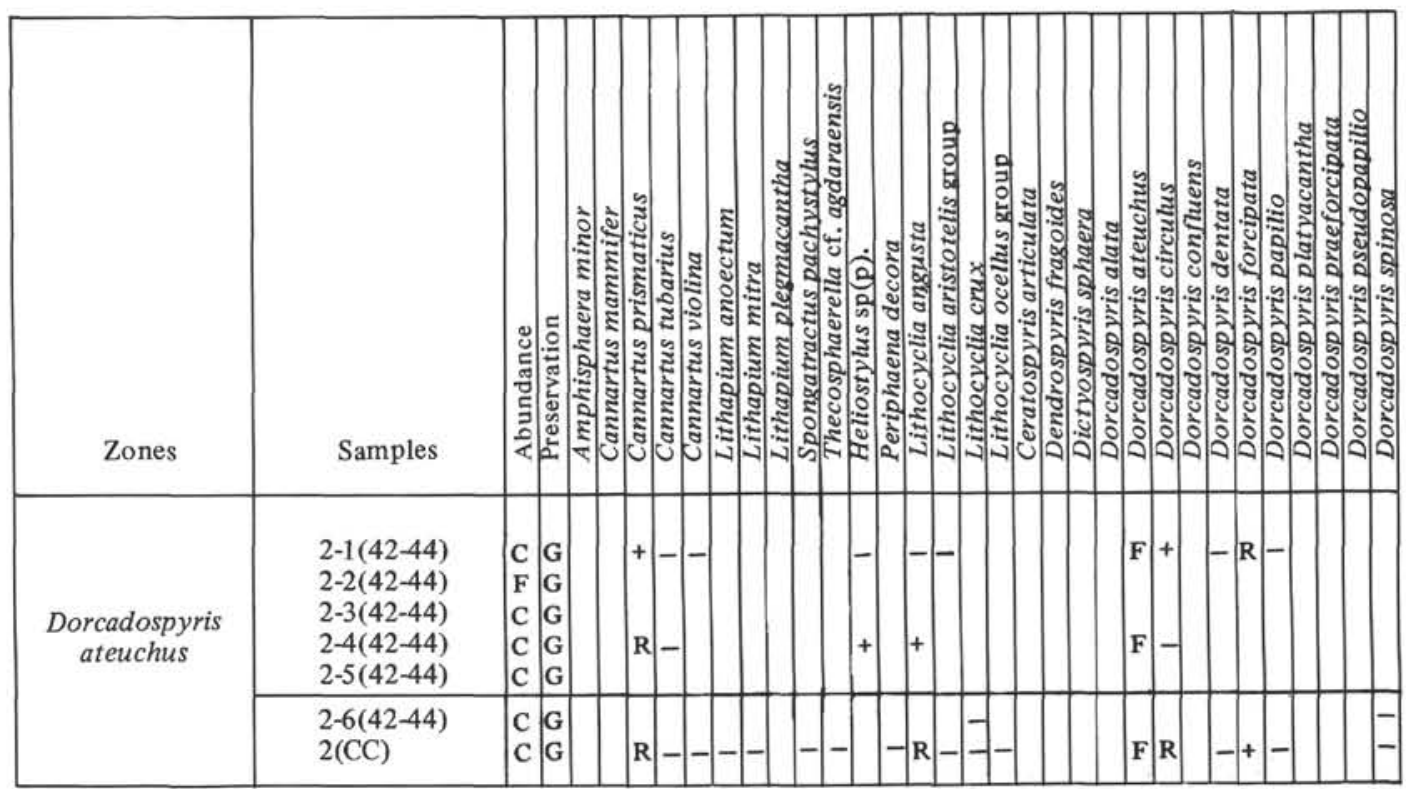


TABLE 7B

Radiolarians from Site 96 (Upper Section)

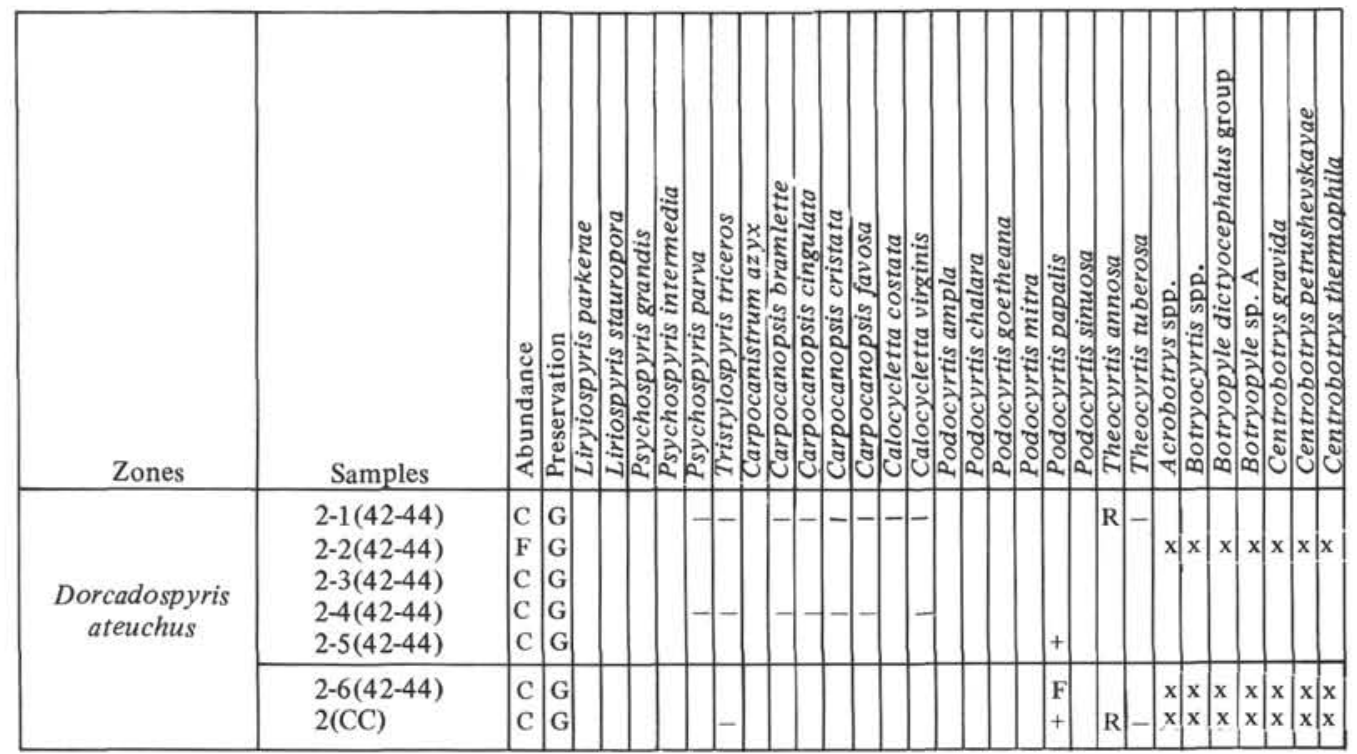

TABLE 8A

Radiolarians from Site 96 (Lower Section)

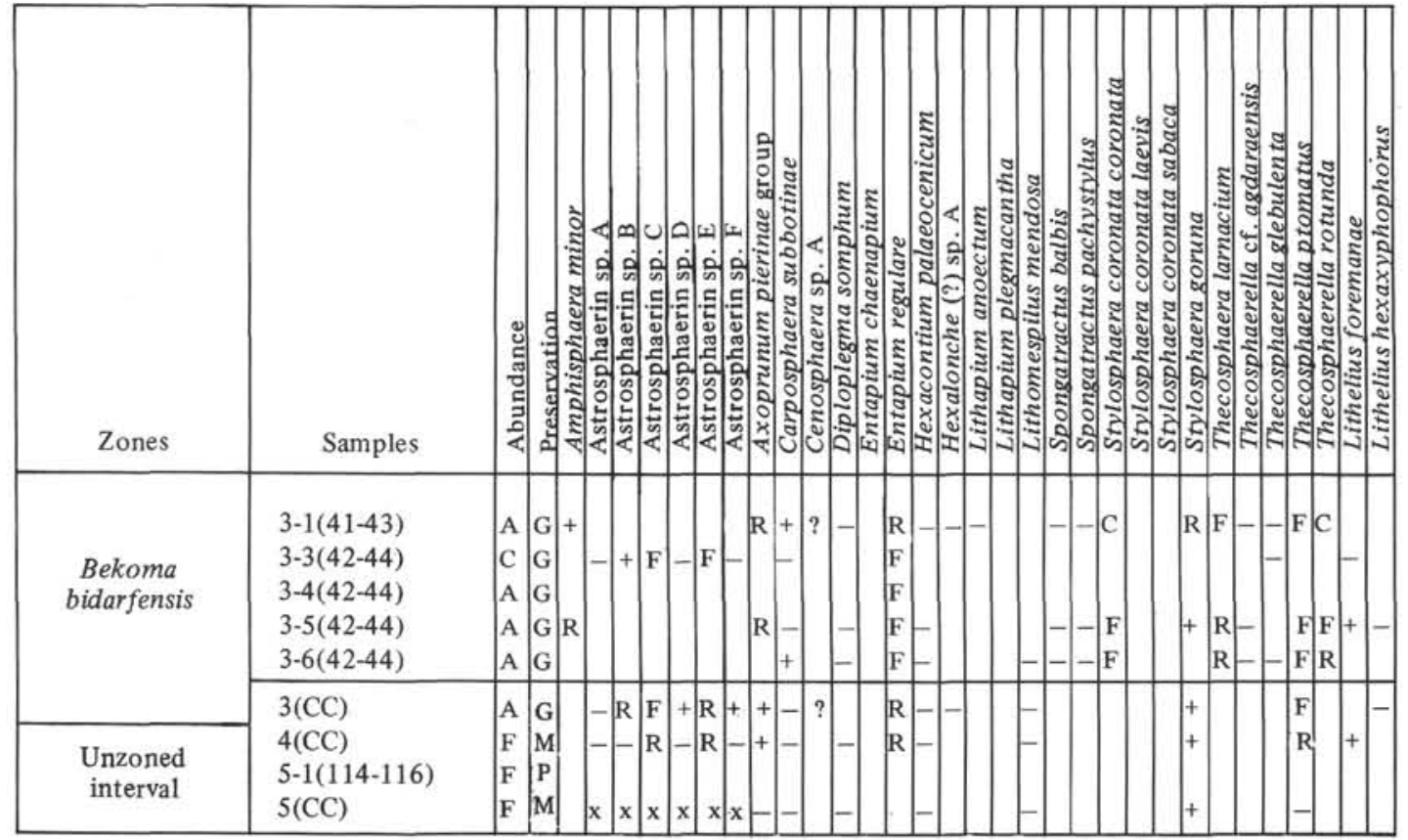


TABLE 8B

Radiolarians from Site 96 (Lower Section)

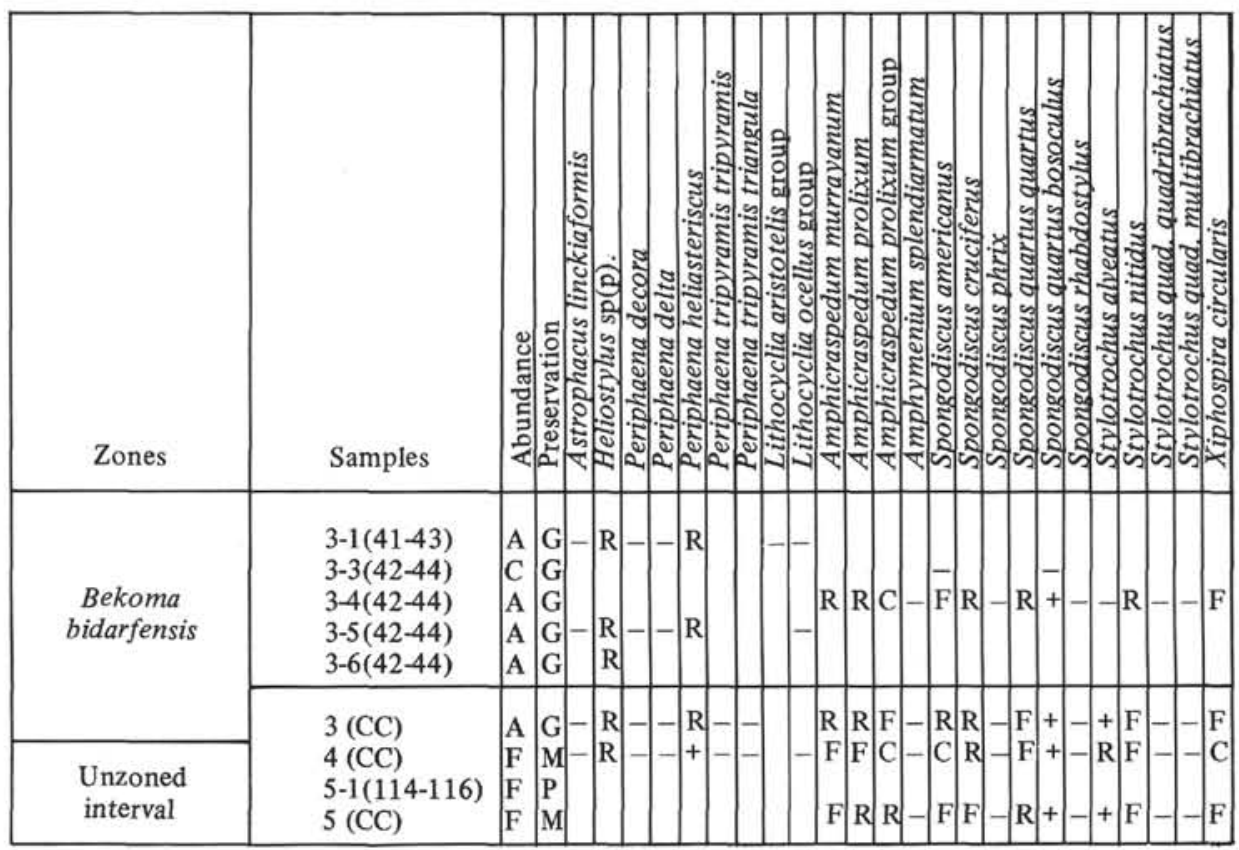

TABLE 8C

Radiolarians from Site 96 (Lower Section)

\begin{tabular}{|c|c|c|c|c|c|c|c|c|c|c|c|c|c|c|c|c|c|c|c|c|c|c|}
\hline Zones & Samples & 造 & & . & $\begin{array}{c}0 \\
0 \\
0 \\
0 \\
0\end{array}$ & 告 & ธี & 暜 & 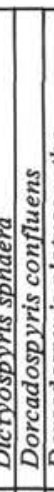 & 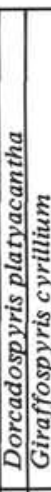 & 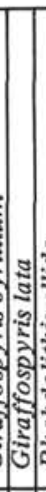 & 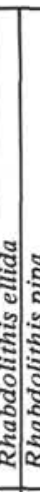 & 웣 & & สํำ & & 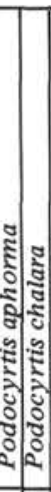 & 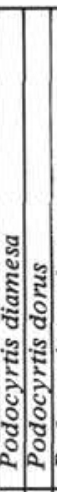 & 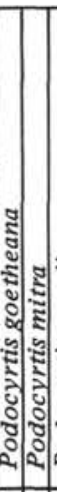 & 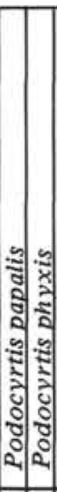 & $\begin{array}{l}3 \\
3 \\
3 \\
3 \\
0 \\
0 \\
0 \\
0 \\
2\end{array}$ & 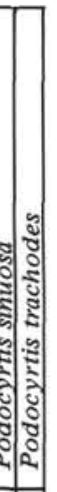 \\
\hline $\begin{array}{c}\text { Bekoma } \\
\text { bidarfensis }\end{array}$ & $\begin{array}{l}3-1(41-43) \\
3-3(42-44) \\
3-4(42-44) \\
3-5(42-44) \\
3-6(42-44) \\
\end{array}$ & 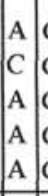 & $\begin{array}{l}G \\
G \\
G \\
G \\
G\end{array}$ & - & $\begin{array}{l}\mathrm{R} \\
\mathrm{F}\end{array}$ & & $\begin{array}{l}\mathrm{R} \\
\mathrm{R}\end{array}$ & & $\begin{array}{l}\mathrm{R} \\
\mathrm{R} \\
\end{array}$ & \begin{tabular}{|l}
$\mathrm{R}$ \\
$\mathrm{R}$
\end{tabular} & $\begin{array}{l}\mathrm{F} \\
\mathrm{F}\end{array}$ & $\begin{array}{l}\mathrm{R} \\
\mathrm{R} \\
\mathbf{H}\end{array}$ & & 1 & $\begin{array}{r}\mathrm{R} \\
+ \\
\end{array}$ & & & & & $\begin{array}{l}\mathrm{F} \\
\mathrm{F} \\
\mathrm{F}\end{array}$ & & \\
\hline $\begin{array}{l}\text { Unzoned } \\
\text { interval }\end{array}$ & $\begin{array}{l}3(C C) \\
4(C C) \\
5-1(114-116) \\
5(C C)\end{array}$ & $\begin{array}{l}\mathrm{A} \\
\mathrm{F} \\
\mathrm{F} \\
\mathrm{F}\end{array}$ & \begin{tabular}{l|l}
$\mathrm{G}$ & - \\
$\mathrm{M}$ & \\
$\mathrm{P}$ & \\
$\mathrm{M}$ &
\end{tabular} & -1 & $\begin{array}{l}\mathrm{F} \\
\mathrm{R}\end{array}$ & & $\begin{array}{l}\mathrm{R} \\
\mathrm{R}\end{array}$ & & $-\begin{array}{r}R \\
+\end{array}$ & + & $\mathrm{F}$ & \begin{tabular}{l|l}
$\mathrm{R}$ & + \\
$\mathrm{R}$ & +
\end{tabular} & & & & & & & & $1-$ & & \\
\hline
\end{tabular}


TABLE 9

Radiolarian events at Sites $86,94,95$, and $96^{\mathrm{a}}$

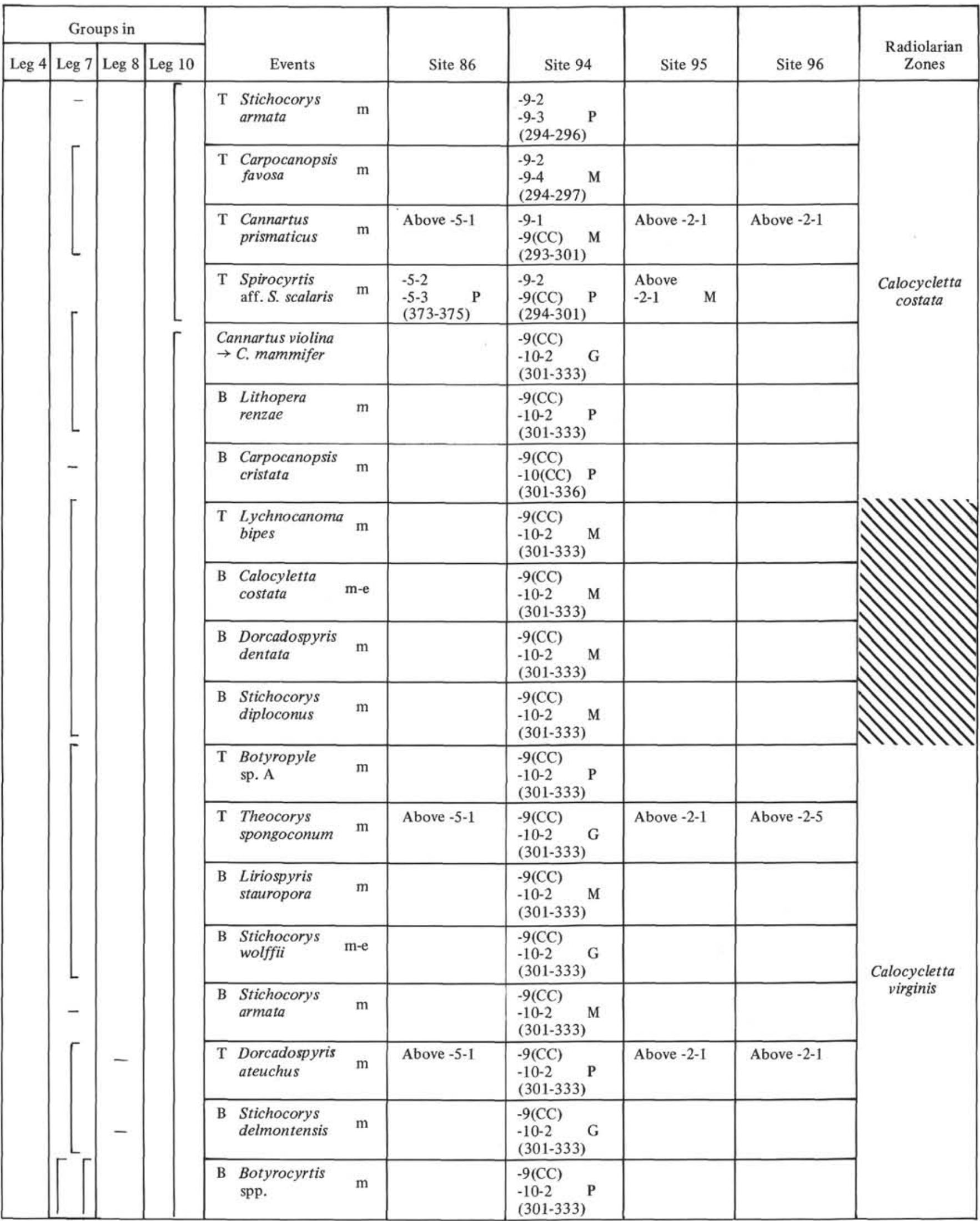

${ }^{\mathrm{a}}$ For explanation, see text Section 6. 
TABLE 9 - Continued

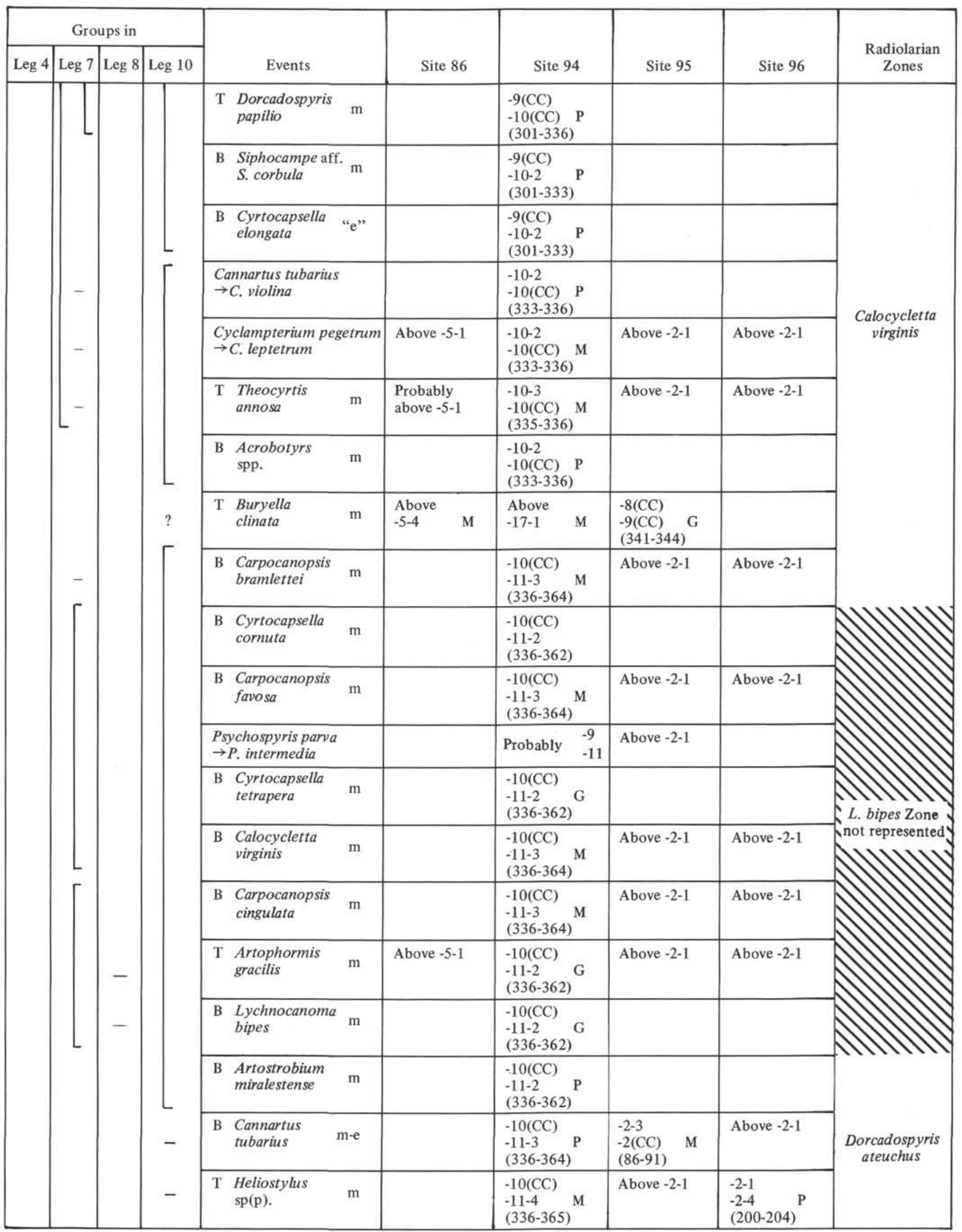


TABLE 9 - Continued

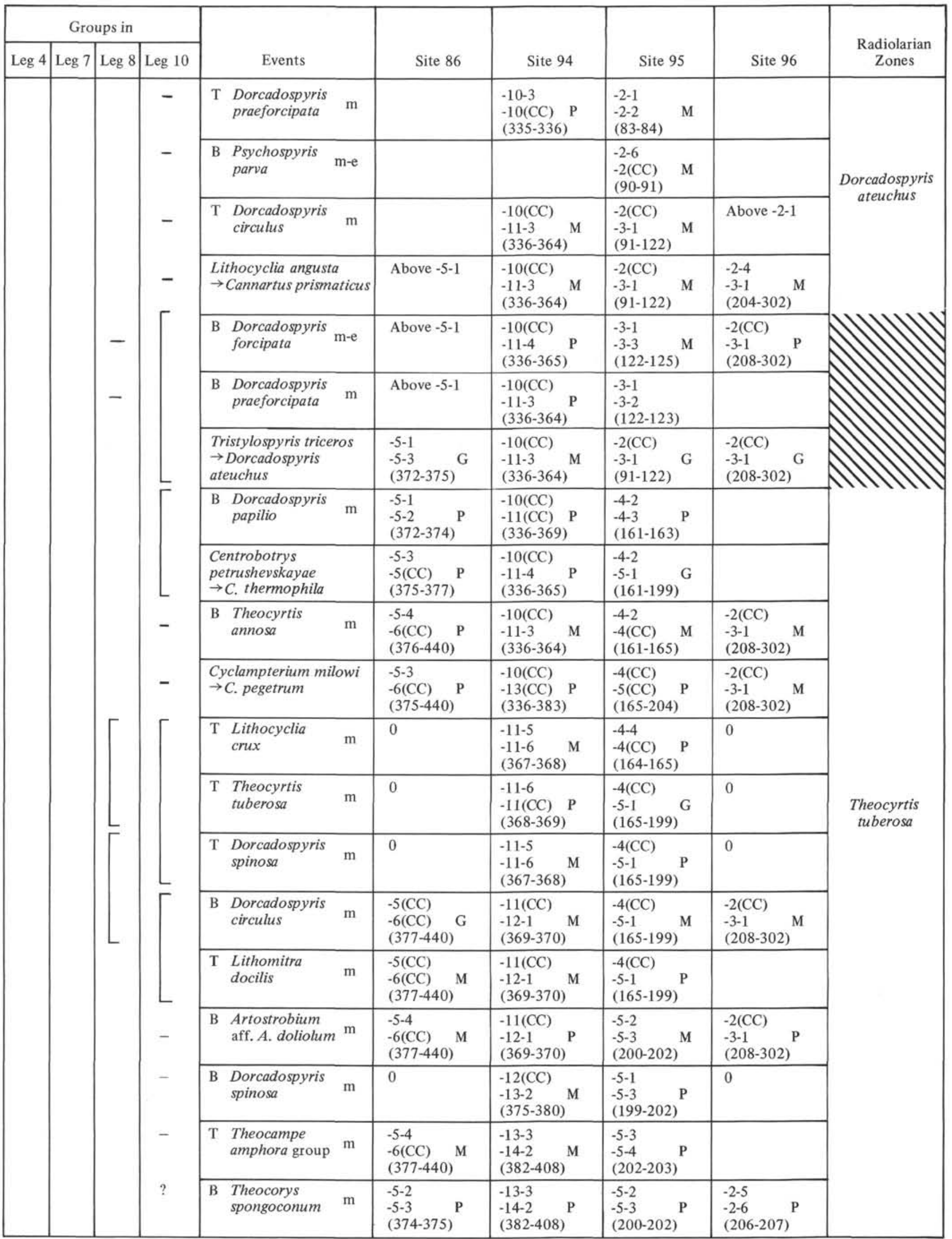


TABLE 9 - Continued

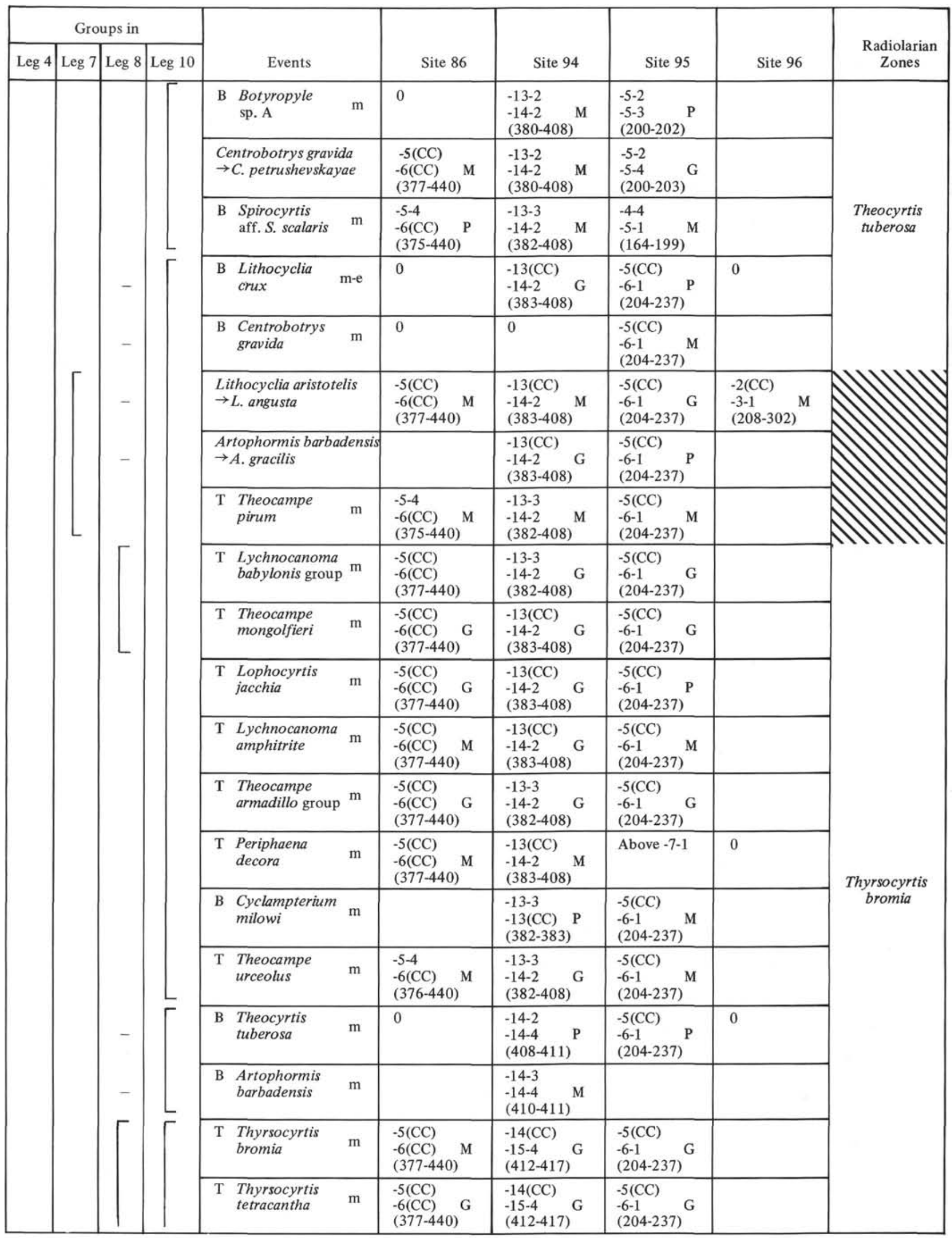


TABLE 9 - Continued

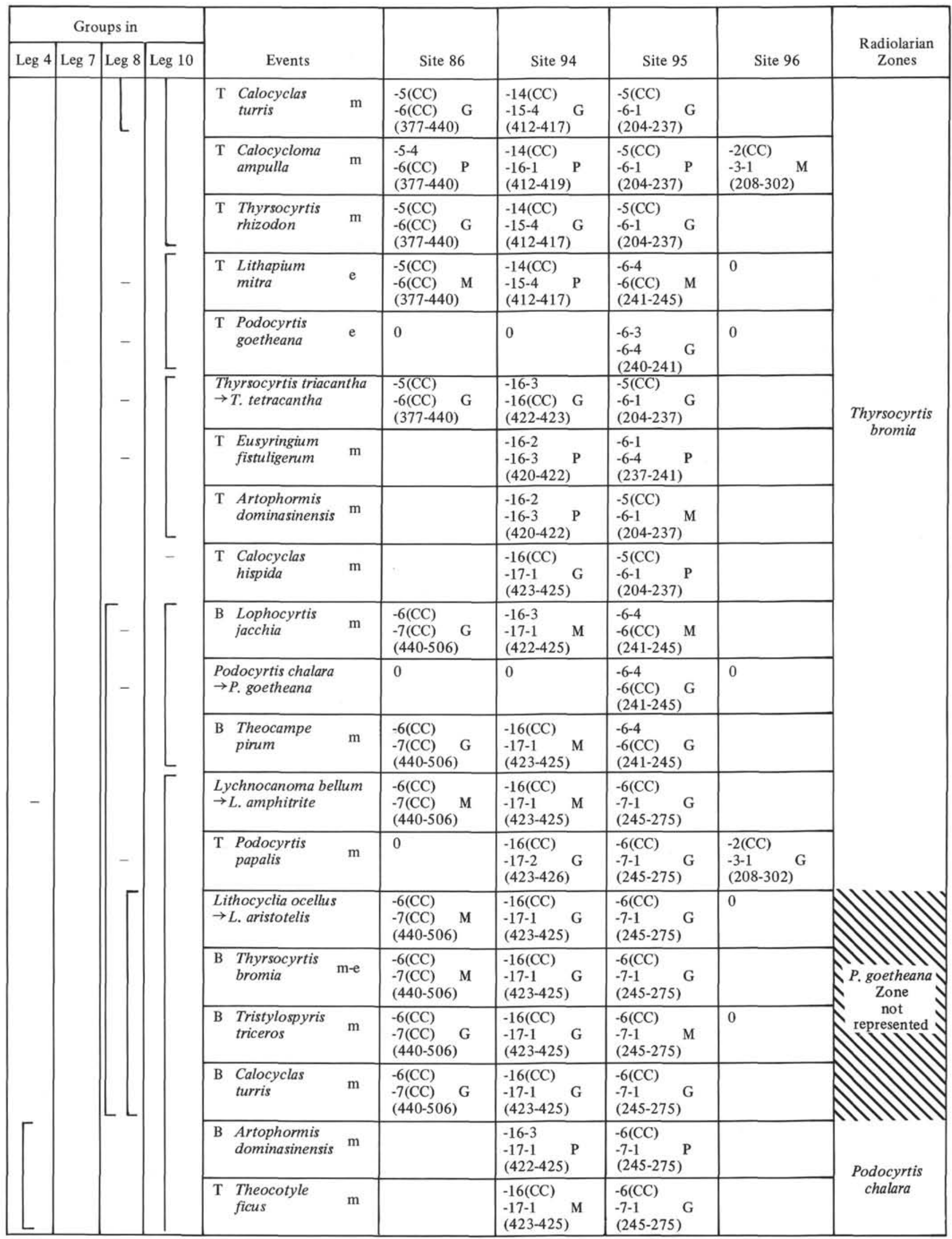


TABLE 9 - Continued

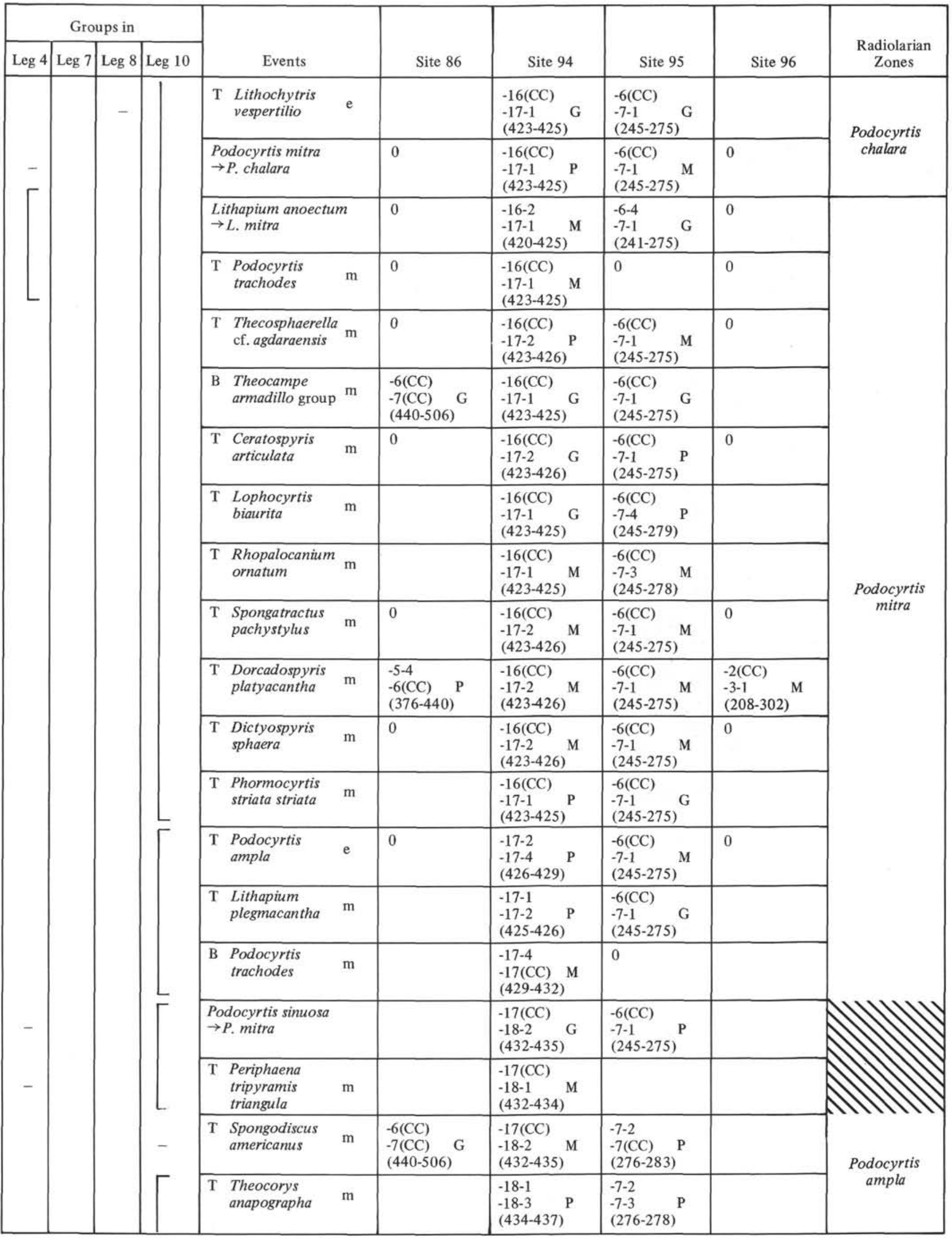


TABLE 9 - Continued

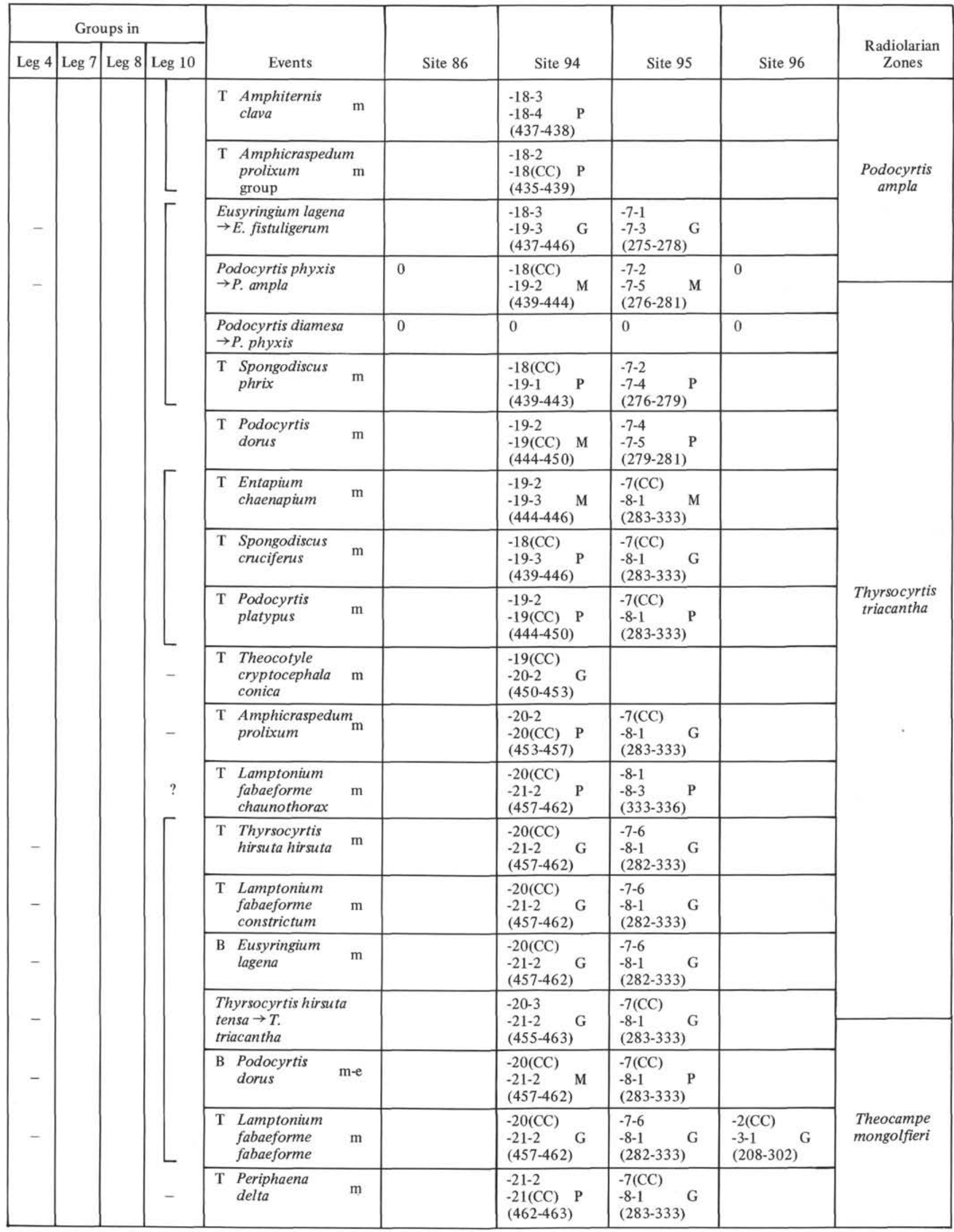


TABLE 9 - Continued

\begin{tabular}{|c|c|c|c|c|c|c|c|c|c|}
\hline \multicolumn{4}{|c|}{ Groups in } & \multirow[b]{2}{*}{ Events } & \multirow[b]{2}{*}{ Site 86} & \multirow[b]{2}{*}{ Site 94} & \multirow[b]{2}{*}{ Site 95} & \multirow[b]{2}{*}{ Site 96} & \multirow{2}{*}{$\begin{array}{c}\text { Radiolarian } \\
\text { Zones }\end{array}$} \\
\hline Leg 4 & Leg 7 & Leg 8 & Leg 10 & & & & & & \\
\hline \multirow{20}{*}{ - } & & & \multirow{6}{*}{$\begin{array}{l}? \\
{\left[\begin{array}{c}{[} \\
\text { ᄃ }\end{array}\right.} \\
{[}\end{array}$} & $\begin{array}{l}\text { T Dorcadospyris } \\
\text { confluens }\end{array}$ & 0 & $\begin{array}{l}-21(C C) \\
-22-1 \quad P \\
(463-470)\end{array}$ & $\begin{array}{l}-7-1 \\
-7-4 \quad P \\
(275-279)\end{array}$ & & \multirow{20}{*}{$\begin{array}{l}\text { Theocampe } \\
\text { mongolfieri }\end{array}$} \\
\hline & & & & $\begin{array}{l}\text { Theocotyle } \\
\text { cryptocephala } \\
\rightarrow \text { T. c. conica }\end{array}$ & & $\begin{array}{l}-21-2 \\
-22-3 \quad G \\
(462-473)\end{array}$ & $\begin{array}{l}-7-6 \\
-8-1 \quad M \\
(282-333)\end{array}$ & & \\
\hline & & & & $\begin{array}{l}\mathrm{T} \text { Giraffospyris } \\
\text { cyrillium }\end{array} \mathrm{m}$ & & $\begin{array}{l}-21(\mathrm{CC}) \\
-22-1 \quad P \\
(463-470)\end{array}$ & $\begin{array}{l}-7(\mathrm{CC}) \\
-8-1 \quad M \\
(283-333)\end{array}$ & & \\
\hline & & & & $\begin{array}{l}\mathrm{T} \text { Thyrsocyrtis } \\
\text { hirsuta robusta }\end{array}$ & & $\begin{array}{l}-22-2 \\
-22-3 \quad P \\
(471-473)\end{array}$ & 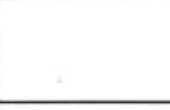 & & \\
\hline & & & & B $\begin{array}{l}\text { Lithapium } \\
\text { anoectum }\end{array}$ m-e & & $\begin{array}{l}-22-2 \\
-22-4 \quad P \\
(471-474)\end{array}$ & $\begin{array}{l}-7(C C) \\
-8-1 \quad M \\
(283-333)\end{array}$ & & \\
\hline & & & & $\begin{array}{l}\mathrm{T} \text { Theocorys } \\
\text { anaclasta }\end{array}$ & & $\begin{array}{l}-22-3 \\
-22-4 \quad M \\
(473-474)\end{array}$ & $\begin{array}{l}-7-6 \\
-8-1 \\
(282-333)\end{array}$ & & \\
\hline & & & & $\begin{array}{l}\mathrm{T} \text { Dictyospyris } \\
\text { discus }\end{array}$ & & $\begin{array}{ll}\text { Within } & \\
-23-2 & P \\
(480) & \\
\end{array}$ & $\begin{array}{l}-7(\mathrm{CC}) \\
-8-1 \quad P \\
(283-333)\end{array}$ & $\begin{array}{l}-2(\mathrm{CC}) \\
-3-1 \quad M \\
(208-302)\end{array}$ & \\
\hline & & & & $\begin{array}{l}\text { Lithochytris archaea } \\
\rightarrow L \text {. vespertilio }\end{array}$ & & $\begin{array}{l}-23-2 \\
-23(\mathrm{CC}) \quad M \\
(480-481)\end{array}$ & $\begin{array}{l}-8-3 \\
-9(\mathrm{CC}) \quad G \\
(336-344)\end{array}$ & & \\
\hline & & & $\Gamma$ & $\begin{array}{l}\text { B Theocampe } \\
\text { mongolfieri }\end{array}$ & $\begin{array}{l}-6(\mathrm{CC}) \\
-7(\mathrm{CC}) \quad G \\
(440-506)\end{array}$ & $\begin{array}{l}-24-3 \\
-24-4 \quad G \\
(491-492)\end{array}$ & $\begin{array}{l}-7-6 \\
-8-1 \quad G \\
(282-333)\end{array}$ & & \\
\hline & & & L & $\begin{array}{l}\mathrm{T} \text { Stylotrochus } \\
\text { quadribrachiatus m } \\
\text { quadribrachiatus }\end{array}$ & & $\begin{array}{l}-24-1 \\
-24-2 \quad M \\
(488-489)\end{array}$ & $\begin{array}{l}-7(\mathrm{CC}) \\
-8-1 \quad G \\
(283-333)\end{array}$ & & \\
\hline & & & $\Gamma$ & $\begin{array}{l}\mathrm{T} \text { Stylotrochus } \\
\text { quadribrachiatus m } \\
\text { multibrachiatus }\end{array}$ & & $\begin{array}{l}-24(\mathrm{CC}) \\
-25-1 \quad M \\
(493-497)\end{array}$ & & & \\
\hline & & & ᄂ & $\begin{array}{l}\text { Podocyrtis aphorma } \\
\rightarrow P \text {. sinuosa }\end{array}$ & 0 & $\begin{array}{l}-24-3 \\
-25-3 \quad G \\
(491-500)\end{array}$ & $\begin{array}{l}-7(\mathrm{CC}) \\
-8-1 \quad G \\
(283-333)\end{array}$ & 0 & \\
\hline & & & - & $\begin{array}{l}\text { T Dendrospyris } \\
\text { turriturcica } \\
\text { turriturcica }\end{array}$ & 0 & $\begin{array}{l}-24(\mathrm{CC}) \\
-25-2 \quad P \\
(493-498)\end{array}$ & $\begin{array}{l}-8-4 \\
-8(C C) \quad P \\
(337-341)\end{array}$ & 0 & \\
\hline & & & - & $\begin{array}{l}\text { T } \begin{array}{l}\text { Stylosphaera } \\
\text { coronata } \\
\text { sabaca }\end{array} \\
\end{array}$ & & $\begin{array}{l}-25-1 \\
-25-2 \quad M \\
(497-498)\end{array}$ & $\begin{array}{l}-7(\mathrm{CC}) \\
-8-1 \quad G \\
(283-333)\end{array}$ & & \\
\hline & & & 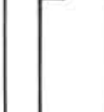 & $\begin{array}{ll}\text { B Thyrsocyrtis } \\
\text { hirsuta robusta }\end{array}$ & & $\begin{array}{l}-25(\mathrm{CC}) \\
-26-2 \quad P \\
(501-502)\end{array}$ & & & \\
\hline & & & & $\begin{array}{l}\text { B Stylotrochus } \\
\text { quadribrachiatus m-e } \\
\text { multibrachiatus } \\
\end{array}$ & & $\begin{array}{l}-25(\mathrm{CC}) \\
-26-2 \quad P \\
(501-502)\end{array}$ & & & \\
\hline & & & ᄂ & $\begin{array}{l}\text { B Lithapium } \\
\text { plegmacantha m-e }\end{array}$ & & $\begin{array}{l}-25(\mathrm{CC}) \\
-26-2 \quad P \\
(501-502)\end{array}$ & $\begin{array}{l}-7(\mathrm{CC}) \\
-8-1 \quad G \\
(283-333)\end{array}$ & & \\
\hline & & & - & $\begin{array}{l}\mathrm{T} \text { Dictyospyris } \\
\text { gigas }\end{array}$ & 0 & $\begin{array}{l}-25-3 \\
-26-2 \quad P \\
(500-502)\end{array}$ & $\begin{array}{l}-8-1 \\
-8-4 \quad P \\
(333-337)\end{array}$ & 0 & \\
\hline & & & $?$ & $\begin{array}{l}\text { B Periphaena } \\
\text { tripyramis } \\
\text { tripyramis }\end{array}$ & & $\begin{array}{l}-29(\mathrm{CC}) \\
-30-1 \quad P \\
(551-572)\end{array}$ & $\begin{array}{l}-8-4 \\
-8(C C) \\
(337-341)\end{array}$ & & \\
\hline & & & - & $\begin{array}{l}\text { B Stylosphaera } \\
\text { coronata } \\
\text { laevis }\end{array}$ & & $\begin{array}{l}-26-2 \\
-26-4 \quad M \\
(502-505)\end{array}$ & $\begin{array}{l}-8-6 \\
-8(C C) \\
(340-341) \\
\end{array}$ & & \\
\hline
\end{tabular}


TABLE 9 - Continued

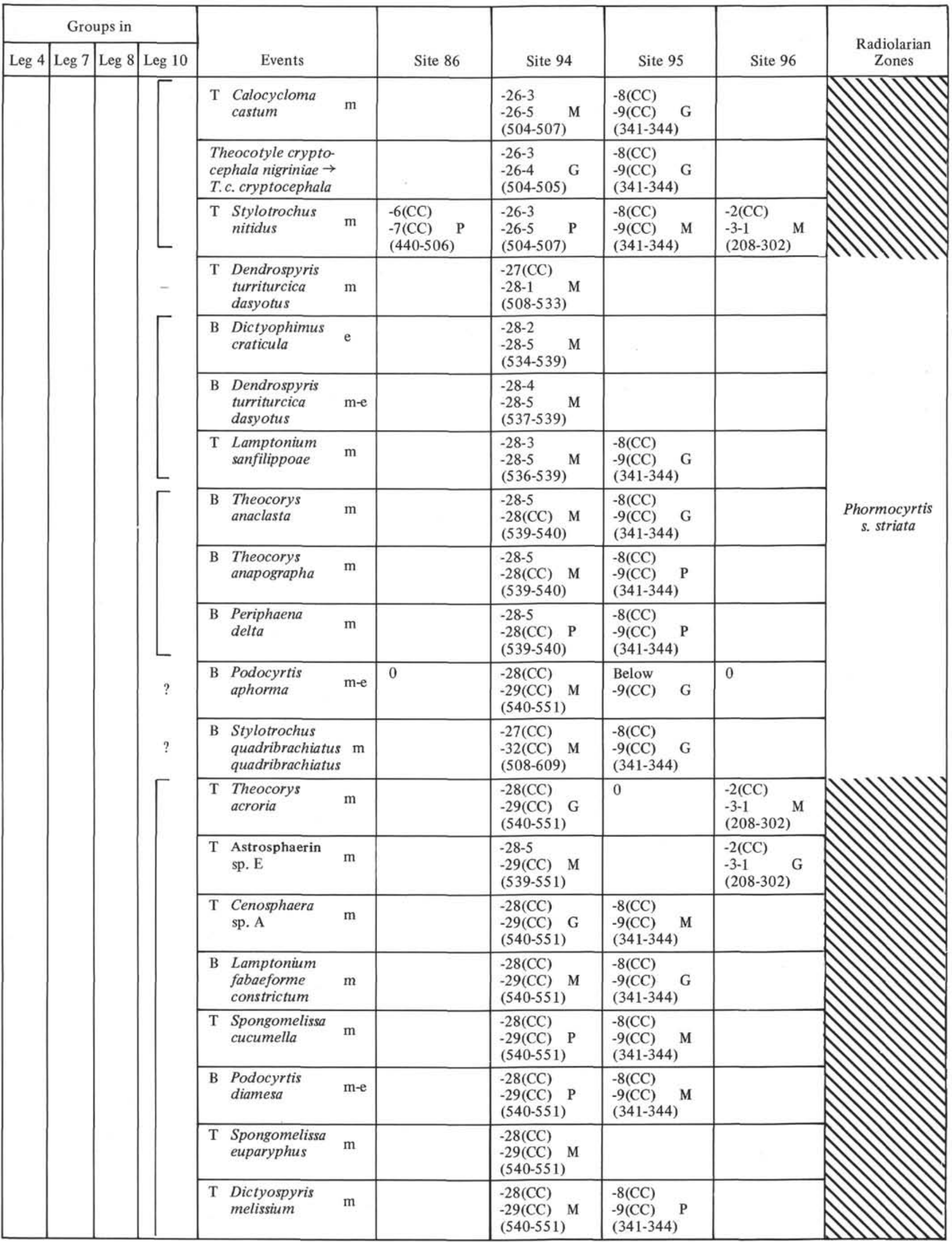


TABLE 9 - Continued

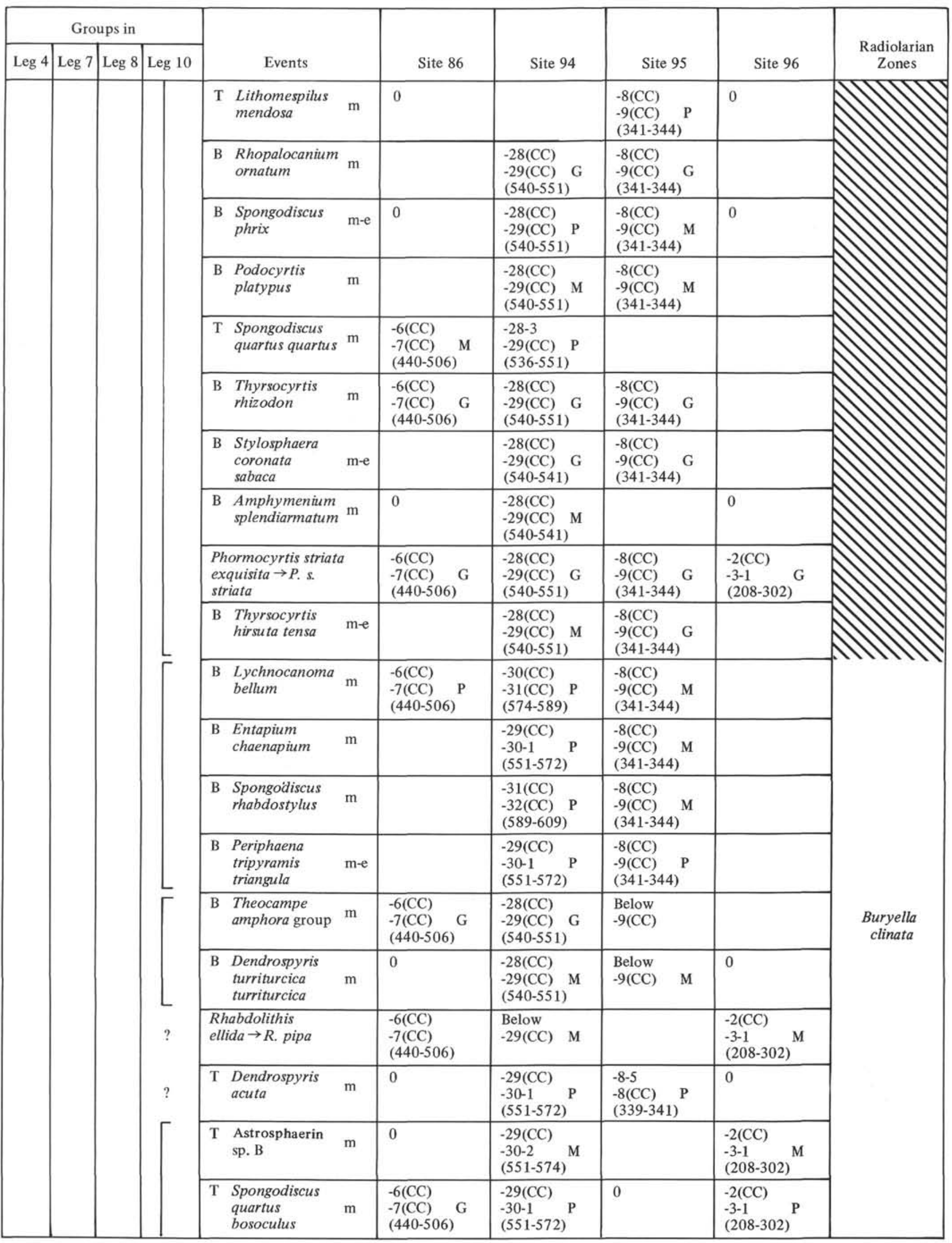


CENOZOIC RADIOLARIA

TABLE 9 - Continued

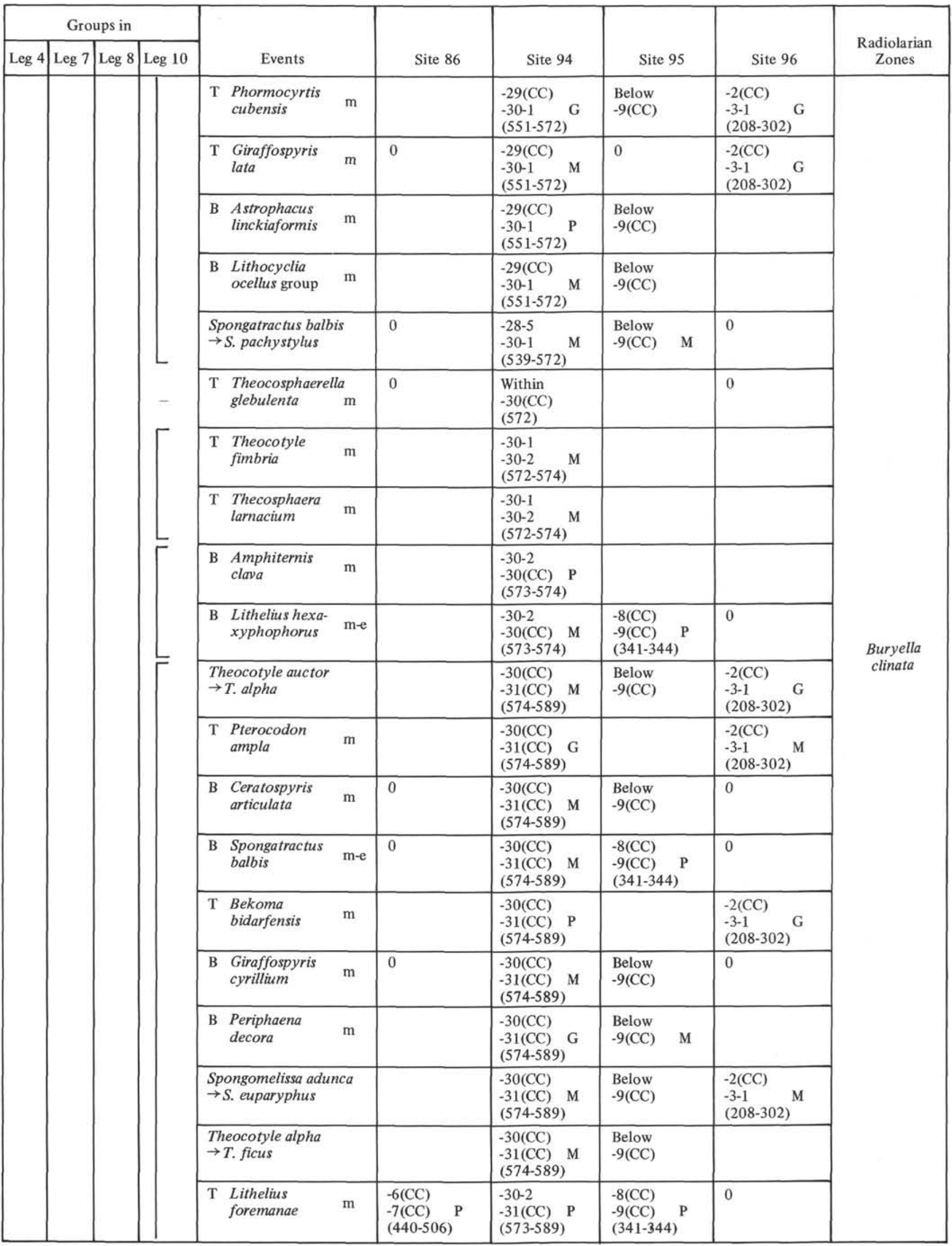


TABLE 9 - Continued

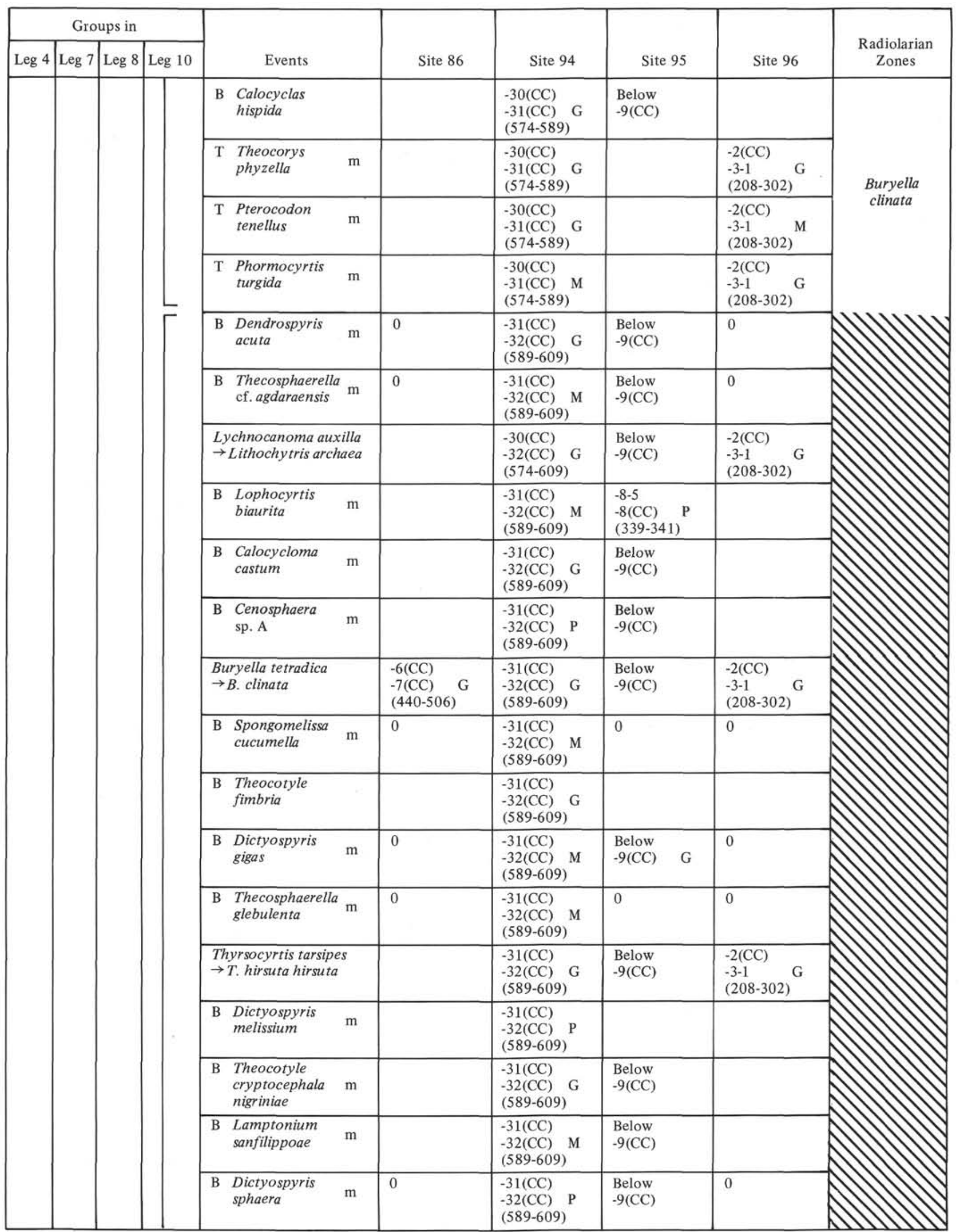


TABLE 9 - Continued

\begin{tabular}{|c|c|c|c|c|c|c|c|c|c|c|c|}
\hline \multicolumn{4}{|c|}{ Groups in } & \multirow{2}{*}{\multicolumn{3}{|c|}{ Events }} & \multirow[b]{2}{*}{ Site 86} & \multirow[b]{2}{*}{ Site 94} & \multirow[b]{2}{*}{ Site 95} & \multirow[b]{2}{*}{ Site 96} & \multirow{2}{*}{$\begin{array}{l}\text { Radiolarian } \\
\text { Zones }\end{array}$} \\
\hline Leg 4 & Leg 7 & Leg 8 & Leg 10 & & & & & & & & \\
\hline & & & L & B & $\begin{array}{l}\text { Theocampe } \\
\text { urceolus }\end{array}$ & $\mathrm{m}$ & $\begin{array}{l}-6(C C) \\
-7(C C) \quad G \\
(440-506)\end{array}$ & $\begin{array}{l}-31(C C) \\
-32(C C) \quad G \\
(589-609)\end{array}$ & $\begin{array}{l}\text { Below } \\
-9(\mathrm{CC})\end{array}$ & & \\
\hline & & & & $T$ & $\begin{array}{l}\text { Astrosphaerin } \\
\text { sp. C }\end{array}$ & $\mathrm{m}$ & & $\begin{array}{l}\text { Below } \\
-32(\mathrm{CC})\end{array}$ & & $\begin{array}{l}-2(C C) \\
-3-1 \quad G \\
(208-302)\end{array}$ & \\
\hline & & & & B & $\begin{array}{l}\text { Lamptonium } \\
\text { fabaeforme } \\
\text { chaunothorax }\end{array}$ & $\mathrm{m}$ & & $\begin{array}{l}\text { Below } \\
-32(\mathrm{CC})\end{array}$ & $\begin{array}{l}\text { Below } \\
-9(\mathrm{CC})\end{array}$ & & \\
\hline & & & & $\mathrm{T}$ & $\begin{array}{l}\text { Stylosphaera } \\
\text { goruna }\end{array}$ & $\mathrm{m}$ & $\begin{array}{l}-6(C C) \\
-7(C C) \quad M \\
(440-506)\end{array}$ & $\begin{array}{l}\text { Below } \\
-32(\mathrm{CC})\end{array}$ & $\begin{array}{l}\text { Below } \\
-9(C C)\end{array}$ & $\begin{array}{l}-2(\mathrm{CC}) \\
-3-1 \quad M \\
(208-302)\end{array}$ & \\
\hline & & & & & $\begin{array}{l}\text { Astrosphaerin } \\
\text { sp. D }\end{array}$ & $\mathrm{m}$ & $\begin{array}{l}-6(\mathrm{CC}) \\
-7(\mathrm{CC}) \quad P \\
(440-506)\end{array}$ & $\begin{array}{l}-30-2 \\
-32(\mathrm{CC}) \quad P \\
(574-609)\end{array}$ & & $\begin{array}{l}-3-3 \\
-3(\mathrm{CC}) \quad P \\
(305-310)\end{array}$ & $\begin{array}{c}\text { Bekoma } \\
\text { bidarfensis }\end{array}$ \\
\hline & & & L & & $\begin{array}{l}\text { Lychnocanoma } \\
\text { aff. L. bellum }\end{array}$ & m & & $\begin{array}{l}-31(\mathrm{CC}) \\
-32(\mathrm{CC}) \quad \mathrm{M} \\
(589-609)\end{array}$ & & $\begin{array}{l}-3-1 \\
-3-3 \quad M \\
(302-305)\end{array}$ & \\
\hline & & & $\Gamma$ & & $\begin{array}{l}\text { Stylotrochus } \\
\text { alveatus }\end{array}$ & $\mathrm{m}$ & $\begin{array}{l}-6(\mathrm{CC}) \\
-7(\mathrm{CC}) \quad M \\
(440-506)\end{array}$ & $\begin{array}{l}\text { Below } \\
-32(\mathrm{CC})\end{array}$ & $\begin{array}{l}\text { Below } \\
-9(\mathrm{CC})\end{array}$ & $\begin{array}{l}-3-5 \\
-3-6 \quad M \\
(308-309)\end{array}$ & \\
\hline & & & L & & $\begin{array}{l}\text { Astrosphaerin } \\
\text { sp. F }\end{array}$ & $\mathrm{m}$ & $\begin{array}{l}-6(C C) \quad P \\
-7(C C) \quad P \\
(440-506)\end{array}$ & $\begin{array}{l}\text { Below } \\
-32(\mathrm{CC})\end{array}$ & & $\begin{array}{l}-3-3 \\
-3(\mathrm{CC}) \quad P \\
(305-310)\end{array}$ & \\
\hline & & & & & $\begin{array}{l}\text { Astrosphaerin } \\
\text { sp. B }\end{array}$ & & 0 & $\begin{array}{l}\text { Below } \\
-32(\mathrm{CC})\end{array}$ & & $\begin{array}{l}-3(C C) \\
-4(C C) \quad M \\
(310-321)\end{array}$ & \\
\hline & & & & & $\begin{array}{l}\text { Theocotyle } \\
\text { auctor }\end{array}$ & & & $\begin{array}{l}\text { Below } \\
-32(\mathrm{CC})\end{array}$ & & $\begin{array}{l}-3(\mathrm{CC}) \\
-4(\mathrm{CC}) \quad \mathrm{M} \\
(310-321)\end{array}$ & \\
\hline & & & & & $\begin{array}{l}\text { Lychnocanoma } \\
\text { aff. } L \text {. bellum }\end{array}$ & $\mathrm{m}$ & & $\begin{array}{l}\text { Below } \\
-32(\mathrm{CC})\end{array}$ & & $\begin{array}{l}-3(\mathrm{CC}) \\
-4(\mathrm{CC}) \quad M \\
(310-321)\end{array}$ & \\
\hline & & & & & $\begin{array}{l}\text { Bekoma } \\
\text { bidarfensis }\end{array}$ & $\mathrm{m}$ & & $\begin{array}{l}\text { Below } \\
-32(\mathrm{CC})\end{array}$ & & $\begin{array}{l}-3(C C) \\
-4(C C) \quad M \\
(310-321)\end{array}$ & \\
\hline & & & & & $\begin{array}{l}\text { imptonium pennatu } \\
\text { L. fabaeforme } \\
\text { baeforme }\end{array}$ & & $\begin{array}{l}-6(C C) \\
-7(C C) \quad G \\
(440-506)\end{array}$ & $\begin{array}{l}\text { Below } \\
-32(\mathrm{CC})\end{array}$ & & $\begin{array}{l}-3-5 \\
-4(\mathrm{CC}) \quad \mathrm{G} \\
(308-321)\end{array}$ & \\
\hline & & & $L$ & & $\begin{array}{l}\text { Pterocodon } \\
\text { tenellus }\end{array}$ & $\mathrm{m}$ & & $\begin{array}{l}\text { Below } \\
-32(\mathrm{CC})\end{array}$ & & $\begin{array}{l}-3(\mathrm{CC}) \\
-4(\mathrm{CC}) \quad \mathrm{M} \\
(310-321)\end{array}$ & \\
\hline & & & $\Gamma$ & & $\begin{array}{l}\text { Theocorys } \\
\text { acroria }\end{array}$ & $\mathrm{m}$ & & $\begin{array}{l}\text { Below } \\
-32(\mathrm{CC})\end{array}$ & & $\begin{array}{l}-4(C C) \\
-5(C C) \quad P \\
(321-331)\end{array}$ & \\
\hline & & & & & $\begin{array}{l}\text { Amphiternis sp. } \\
\text { cf. Stichomitra } \\
\text { alamedaensis }\end{array}$ & $\mathrm{m}$ & $\begin{array}{l}-6(\mathrm{CC}) \\
-7(\mathrm{CC}) \quad M \\
(440-506)\end{array}$ & & & $\begin{array}{l}-4(\mathrm{CC}) \\
-5(\mathrm{CC}) \quad P \\
(321-331)\end{array}$ & \\
\hline & & & & & $\begin{array}{l}\text { Pterocodon } \\
\text { ampla }\end{array}$ & $\mathrm{m}$ & & $\begin{array}{l}\text { Below } \\
-32(C C)\end{array}$ & & $\begin{array}{l}-4(C C) \\
-5(C C) \quad P \\
(321-331)\end{array}$ & Unzoned \\
\hline & & & & & $\begin{array}{l}\text { Astrosphaerin } \\
\text { sp. A }\end{array}$ & $\mathrm{m}$ & $\begin{array}{l}-6(C C) \\
-7(C C) \\
(440-506)\end{array}$ & $\begin{array}{l}\text { Below } \\
-32(\mathrm{CC})\end{array}$ & & $\begin{array}{l}\text { Below } \\
-4(C C)\end{array}$ & \\
\hline & & & & & $\begin{array}{l}\text { Astrosphaerin } \\
\text { sp. C }\end{array}$ & $\mathrm{m}$ & 0 & $\begin{array}{l}\text { Below } \\
-32(\mathrm{CC})\end{array}$ & & $\begin{array}{l}\text { Below } \\
-4(C C)\end{array}$ & \\
\hline & & & & & $\begin{array}{l}\text { Lychnocanoma } \mathrm{n} \\
\text { auxilla }\end{array}$ & & & $\begin{array}{l}\text { Below } \\
-32(\mathrm{CC})\end{array}$ & & $\begin{array}{l}-4(C C) \\
-5(C C) \quad P \\
(321-331)\end{array}$ & \\
\hline
\end{tabular}


TABLE 9 - Continued

\begin{tabular}{|c|c|c|c|c|c|c|c|c|c|c|c|}
\hline \multicolumn{4}{|c|}{ Groups in } & \multirow{2}{*}{\multicolumn{3}{|c|}{ Events }} & \multirow[b]{2}{*}{ Site 86} & \multirow[b]{2}{*}{ Site 94} & \multirow[b]{2}{*}{ Site 95} & \multirow[b]{2}{*}{ Site 96} & \multirow{2}{*}{$\begin{array}{c}\text { Radiolarian } \\
\text { Zones }\end{array}$} \\
\hline Leg 4 & Leg 7 & Leg 8 & Leg 10 & & & & & & & & \\
\hline & & & & B & $\begin{array}{l}\text { Lychnocanoma } \\
\text { babylonis } \\
\text { group }\end{array}$ & $\mathrm{m}$ & $\begin{array}{l}-6(\mathrm{CC}) \\
-7(\mathrm{CC}) \quad \mathrm{G} \\
(440-506)\end{array}$ & $\begin{array}{l}\text { Below } \\
-32(\mathrm{CC}) \quad \mathrm{M}\end{array}$ & $\begin{array}{l}\text { Below } \\
-9(\mathrm{CC})\end{array}$ & $\begin{array}{l}-4(C C) \\
-5(C C) \quad M \\
(321-331)\end{array}$ & \multirow{21}{*}{ Unzoned } \\
\hline & & & & B & $\begin{array}{l}\text { Giraffospyris } \\
\text { lata }\end{array}$ & $\mathrm{m}$ & 0 & $\begin{array}{l}\text { Below } \\
-32(\mathrm{CC}) \quad \mathrm{M} \\
\end{array}$ & $\begin{array}{l}\text { Below } \\
-9(C C) \\
\end{array}$ & $\begin{array}{l}\text { Below } \\
-4(\mathrm{CC}) \\
\end{array}$ & \\
\hline & & & & B & $\begin{array}{l}\text { Podocyrtis } \\
\text { papalis }\end{array}$ & $\mathrm{m}$ & & & $\begin{array}{l}\text { Below } \\
-9(C C)\end{array}$ & $\begin{array}{l}-4(C C) \\
-5(C C) \quad G \\
(321-331)\end{array}$ & \\
\hline & & & & $\mathrm{T}$ & $\begin{array}{l}\text { Buryella } \\
\text { pentadica }\end{array}$ & $\mathrm{m}$ & $\begin{array}{l}-6(\mathrm{CC}) \\
-7(\mathrm{CC}) \quad \mathrm{G} \\
(440-506)\end{array}$ & & & $\begin{array}{l}-4(C C) \\
-5(C C) \quad P \\
(321-331)\end{array}$ & \\
\hline & & & & B & $\begin{array}{l}\text { Theocorys } \\
\text { phyzella }\end{array}$ & $\mathrm{m}$ & & $\begin{array}{l}\text { Below } \\
-32(\mathrm{CC})\end{array}$ & & $\begin{array}{l}-4(C C) \\
-5(C C) \quad M \\
(321-331)\end{array}$ & \\
\hline & & & & B & $\begin{array}{l}\text { Dorcadospyris } \\
\text { platyacantha }\end{array}$ & $\mathrm{m}$ & $\begin{array}{l}-6(C C) \\
-7(C C) \quad M \\
(440-506)\end{array}$ & $\begin{array}{l}\text { Below } \\
-32(\mathrm{CC})\end{array}$ & $\begin{array}{l}\text { Below } \\
-9(C C)\end{array}$ & $\begin{array}{l}\text { Below } \\
-4(C C)\end{array}$ & \\
\hline & & & & B & $\begin{array}{l}\text { Thecosphaerella } \\
\text { ptomatus }\end{array}$ & $\mathrm{m}$ & 0 & $\begin{array}{l}\text { Below } \\
-32(C C)\end{array}$ & $\begin{array}{l}-8-6 \\
-8(C C) \quad P \\
(340-341)\end{array}$ & $\begin{array}{l}-4(C C) \\
-5(C C) \quad M \\
(321-331)\end{array}$ & \\
\hline & & & & B & $\begin{array}{l}\text { Thyrsocyrtis } \\
\text { tarsipes }\end{array}$ & $\mathrm{m}$ & & $\begin{array}{l}\text { Below } \\
-32(\mathrm{CC})\end{array}$ & & $\begin{array}{l}-4(C C) \\
-5(C C) \quad P \\
(321-331)\end{array}$ & \\
\hline & & & & B & $\begin{array}{l}\text { Phormocyrtis } \\
\text { turgida }\end{array}$ & $\mathrm{m}$ & & $\begin{array}{l}\text { Below } \\
-32(\mathrm{CC})\end{array}$ & & $\begin{array}{l}-4(C C) \\
-5(C C) \quad P \\
(321-331)\end{array}$ & \\
\hline & & & & & $\begin{array}{l}\text { Calocycloma } \\
\text { ampulla }\end{array}$ & $\mathrm{m}$ & & $\begin{array}{l}\text { Below } \\
-32(\mathrm{CC}) \\
\end{array}$ & $\begin{array}{l}\text { Below } \\
-9(C C) \\
\end{array}$ & $\begin{array}{l}\text { Below } \\
-5(\mathrm{CC}) \\
\end{array}$ & \\
\hline & & & & & $\begin{array}{l}\text { Lychnocanoma } \\
\text { anacolum }\end{array}$ & $\mathrm{m}$ & $\begin{array}{l}-6(\mathrm{CC}) \\
-7(\mathrm{CC}) \quad G \\
(440-506)\end{array}$ & & & & \\
\hline & & & & & $\begin{array}{l}\text { Dictyoceras } \\
\text { caia }\end{array}$ & $\mathrm{m}$ & $\begin{array}{l}-6(\mathrm{CC}) \\
-7(\mathrm{CC}) \quad \mathrm{G} \\
(440-506)\end{array}$ & & & & \\
\hline & & & & $\mathrm{T}$ & $\begin{array}{l}\text { Bekoma } \\
\text { campechensis }\end{array}$ & $\mathrm{m}$ & $\begin{array}{l}-6(C C) \\
-7(C C) \quad G \\
(440-506)\end{array}$ & & & & \\
\hline & & & & & $\begin{array}{l}\text { Clathrocycloma } \\
\text { capitaneum }\end{array}$ & $\mathrm{m}$ & $\begin{array}{l}-6(C C) \\
-7(C C) \quad G \\
(440-506)\end{array}$ & & & & \\
\hline & & & & & $\begin{array}{l}\text { Lamptonium } \\
\text { colymbus }\end{array}$ & $\mathrm{m}$ & $\begin{array}{l}-6(\mathrm{CC}) \\
-7(\mathrm{CC}) \quad \mathrm{G} \\
(440-506)\end{array}$ & & & & \\
\hline & & & & & $\begin{array}{l}\text { Orbula } \\
\text { comitata }\end{array}$ & $\mathrm{m}$ & $\begin{array}{l}-6(C C) \\
-7(C C) \quad G \\
(440-506)\end{array}$ & & & & \\
\hline & & & & & $\begin{array}{l}\text { Dorcadospyris } \\
\text { confluens }\end{array}$ & $\mathrm{m}$ & 0 & $\begin{array}{l}\text { Below } \\
-32(\mathrm{CC})\end{array}$ & $\begin{array}{l}-8(C C) \\
-9(C C) \quad M \\
(341-344)\end{array}$ & $\begin{array}{l}\text { Below } \\
-4(\mathrm{CC}) \quad \mathrm{M}\end{array}$ & \\
\hline & & & & & $\begin{array}{l}\text { Spongodiscus } \\
\text { cruciferus }\end{array}$ & $\mathrm{m}$ & $\begin{array}{l}-6(C C) \\
-7(C C) \quad G \\
(440-506)\end{array}$ & $\begin{array}{l}\text { Below } \\
-32(\mathrm{CC}) \quad \mathrm{M}\end{array}$ & $\begin{array}{l}-8(C C) \\
-9(C C) \quad M \\
(341-344)\end{array}$ & $\begin{array}{l}\text { Below } \\
-4(\mathrm{CC}) \quad \text { G }\end{array}$ & \\
\hline & & & & & $\begin{array}{l}\text { Phormocyrtis } \\
\text { cubensis }\end{array}$ & $\mathrm{m}$ & & $\begin{array}{l}\text { Below } \\
-32(\mathrm{CC})\end{array}$ & & $\begin{array}{l}\text { Below } \\
-5(\mathrm{CC}) \\
\end{array}$ & \\
\hline & & & & & $\begin{array}{l}\text { Bekoma } \\
\text { demissa }\end{array}$ & $\mathrm{m}$ & $\begin{array}{l}-6(C C) \\
-7(C C) \quad G \\
(440-506)\end{array}$ & & & & \\
\hline & & & & & $\begin{array}{l}\text { Orbula } \\
\text { discipulus }\end{array}$ & $\mathrm{m}$ & $\begin{array}{l}-6(C C) \\
-7(C C) \quad G \\
(440-506)\end{array}$ & & & & \\
\hline
\end{tabular}


TABLE 9 - Continued

\begin{tabular}{|c|c|c|c|c|c|c|c|c|c|c|}
\hline \multicolumn{4}{|c|}{ Groups in } & \multirow{2}{*}{\multicolumn{2}{|c|}{ Events }} & \multirow[b]{2}{*}{ Site 86} & \multirow[b]{2}{*}{ Site 94} & \multirow[b]{2}{*}{ Site 95} & \multirow[b]{2}{*}{ Site 96} & \multirow{2}{*}{$\begin{array}{l}\text { Radiolarian } \\
\text { Zones }\end{array}$} \\
\hline Leg 4 & $\operatorname{Leg} 7$ & Leg 8 & Leg 10 & & & & & & & \\
\hline & & & & B & $\begin{array}{l}\text { Dictyospyris } \\
\text { discus }\end{array}$ & 0 & $\begin{array}{l}\text { Below } \\
-32(\mathrm{CC}) \quad \mathrm{M}\end{array}$ & $\begin{array}{l}-8(C C) \\
-9(C C) \quad M \\
(341-344)\end{array}$ & $\begin{array}{l}\text { Below } \\
-4(C C) \quad M\end{array}$ & \\
\hline & & & & $T$ & $\begin{array}{l}\text { Bekoma } \\
\text { divaricata }\end{array}$ & $\begin{array}{l}-6(C C) \\
-7(C C) \quad G \\
(440-506)\end{array}$ & & & & \\
\hline & & & & & $\begin{array}{l}\text { Orbula } \\
\text { ducalis }\end{array}$ & $\begin{array}{l}-6(C C) \\
-7(C C) \quad G \\
(440-506)\end{array}$ & & & & \\
\hline & & & & & $\begin{array}{l}\text { Hexalonche } \\
\text { sp. A }\end{array}$ & $\begin{array}{l}-6(C C) \\
-7(C C) \quad P \\
(440-506)\end{array}$ & 0 & $\begin{array}{l}\text { Below } \\
-9(\mathrm{CC})\end{array}$ & $\begin{array}{l}\text { Below } \\
-4(C C)\end{array}$ & \\
\hline & & & & & $\begin{array}{l}\text { Lamptonium } \\
\text { incohatum }\end{array}$ & $\begin{array}{l}-6(C C) \\
-7(C C) \quad G \\
(440-506)\end{array}$ & & & & \\
\hline & & & & & $\begin{array}{l}\text { Amphicraspedum } \\
\text { murrayanum } \mathrm{m}\end{array}$ & $\begin{array}{l}-6(C C) \\
-7(C C) \quad G \\
(440-506)\end{array}$ & $\begin{array}{l}\text { Below } \\
-32(\mathrm{CC}) \quad \mathrm{M}\end{array}$ & 0 & $\begin{array}{l}\text { Below } \\
-4(C C) \quad G\end{array}$ & \\
\hline & & & & & $\begin{array}{l}\text { Hexacontium } \\
\text { palaeocenicum }\end{array}$ & $\begin{array}{l}-6(C C) \\
-7(C C) \quad G \\
(440-506)\end{array}$ & $\begin{array}{l}\text { Below } \\
-32(\mathrm{CC})\end{array}$ & $\begin{array}{l}\text { Below } \\
-9(C C)\end{array}$ & $\begin{array}{l}\text { Below } \\
-5(C C)\end{array}$ & Unzoned \\
\hline & & & & & $\begin{array}{l}\text { Clathrocycloma } \mathrm{m} \\
\text { parcum }\end{array}$ & $\begin{array}{l}-6(C C) \\
-7(C C) \quad G \\
(440-506)\end{array}$ & & & & \\
\hline & & & & & $\begin{array}{l}\text { Amphicraspedum } \\
\text { prolixum }\end{array}$ & $\begin{array}{l}-6(C C) \\
-7(C C) \quad M \\
(440-506)\end{array}$ & $\begin{array}{l}\text { Below } \\
-32(\mathrm{CC}) \quad \mathrm{G}\end{array}$ & $\begin{array}{l}\text { Below } \\
-9(C C)\end{array}$ & $\begin{array}{l}\text { Below } \\
-4(C C)\end{array}$ & \\
\hline & & & & & $\begin{array}{l}\text { Amphicraspedum } \\
\text { prolixum } \\
\text { group }\end{array}$ & $\begin{array}{l}-6(\mathrm{CC}) \\
-7(\mathrm{CC}) \quad \mathrm{M} \\
(440-506)\end{array}$ & $\begin{array}{l}\text { Below } \\
-32(\mathrm{CC}) \quad \mathrm{G}\end{array}$ & $\begin{array}{l}\text { Below } \\
-9(C C) \quad M\end{array}$ & $\begin{array}{l}\text { Below } \\
-4(C C)\end{array}$ & \\
\hline & & & & B & $\begin{array}{l}\text { Spongodiscus } \\
\text { quartus quartus }\end{array}$ & $\begin{array}{l}-6(\mathrm{CC}) \\
-7(\mathrm{CC}) \quad M \\
(440-506)\end{array}$ & $\begin{array}{l}\text { Below } \\
-32(\mathrm{CC}) \quad \mathrm{G}\end{array}$ & 0 & $\begin{array}{ll}\text { Below } & \\
-5(\mathrm{CC}) \quad \mathrm{P}\end{array}$ & \\
\hline & & & & & $\begin{array}{l}\text { Diploplegma } \\
\text { somphum }\end{array}$ & $\begin{array}{l}-6(\mathrm{CC}) \\
-7(\mathrm{CC}) \quad \mathrm{G} \\
(440-506)\end{array}$ & $\begin{array}{l}\text { Below } \\
-32(C C)\end{array}$ & $\begin{array}{l}\text { Below } \\
-9(C C)\end{array}$ & $\begin{array}{l}\text { Below } \\
-5(C C)\end{array}$ & \\
\hline & & & - & & $\begin{array}{l}\text { Stylotrochus } \\
\text { nitidus }\end{array}$ & $\begin{array}{l}-7(\mathrm{CC}) \\
-8-2 \quad P \\
(506-511)\end{array}$ & $\begin{array}{l}\text { Below } \\
-32(\mathrm{CC})\end{array}$ & $\begin{array}{l}\text { Below } \\
-9(\mathrm{CC})\end{array}$ & $\begin{array}{l}\text { Below } \\
-4(C C)\end{array}$ & \\
\hline
\end{tabular}

the bars between pores. Medullary shell double, the outer one subspherical, joined to the cortical shell by six strong bars collinear with the external spines.

Measurements (based on 25 specimens from 86-7, CC and 86-8, CC). Diameter of cortical shell $150-190 \mu$, of outer medullary shell 45-55 $\mu$.

Remarks: This species is characterized by the short, heavy, bladed spines, and the hexagonally framed rosette-shaped pores. H. palaeocenicum is placed in the genus Hexacontium as a matter of temporary convenience only (pending elucidation of actinommid lineages), and is evidently closely related to Thecosphaerella cf. agdaraensis, $T$. glebulenta and $T$. rotunda. The possibility of this relationship is supported by the fact that both Hexacontium palaeocenicum and Thecosphaerella rotunda are in some assemblages accompanied by forms differing only in that the cortical shell is double, the two shells joined by very closely spaced bars, and the outer one having much smaller pores (usually three overlying each pore of the inner cortical shell).

\section{8(2)J. Genus HEXALONCHE Haeckel}

Hexalonche Haeckel, 1881, p. 451. Type species (indicated by Campbell, 1954 , p. 60) Hexalonche phaenaxonia Haeckel (1887, p. 180).
8(2)Ja. Hexalonche (?) sp. A

(Plate 4, Figure 1; Plate 24, Figure 5)

Description: Cortical shell moderately thick-walled, with minutely thorny surface and bearing approximately 6 thin cylindrical spines with bladed bases, their length approaching the diameter of the cortical shell when not broken. Pores subcircular to circular, irregular in size and arrangement (distance between centers approximately 7.5-15 $\mu$ ). Rare specimens have remnants of internal bars collinear with the external spines, and thus completely developed and perfectly preserved specimens would presumably possess a delicate medullary shell.

Measurements (based on 25 specimens from 86-8-3 and 86-8, CC). Diameter of cortical shell $90-130 \mu$.

Remarks: This species is distinguished by its thin cylindrical spines, and the delicacy of the rarely-preserved internal structures. It is not named because we do not know the structure of the medullary shell, and it somewhat resembles a large form with smaller, more regular pores, mentioned in the discussion of Amphisphaera minor.

\section{8(2)K. Genus LITHAPIUM Haeckel}

Lithapium Haeckel, 1887, p. 303; Riedel and Sanfilippo, 1970, p. 520. 
A. SANFILIPPO, W. R. RIEDEL

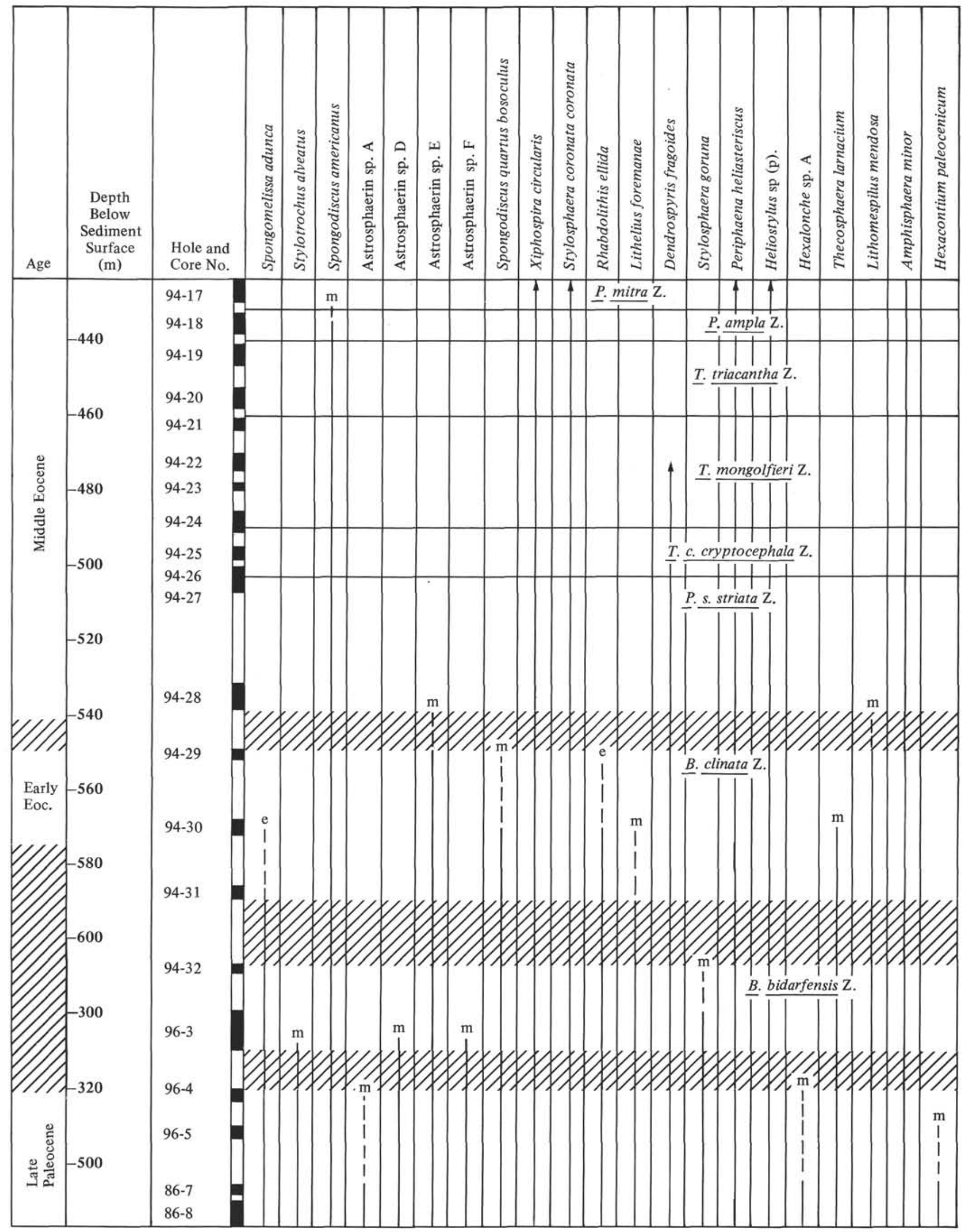

Figure 5. Radiolarian ranges for late Paleocene through part of middle Eocene. 


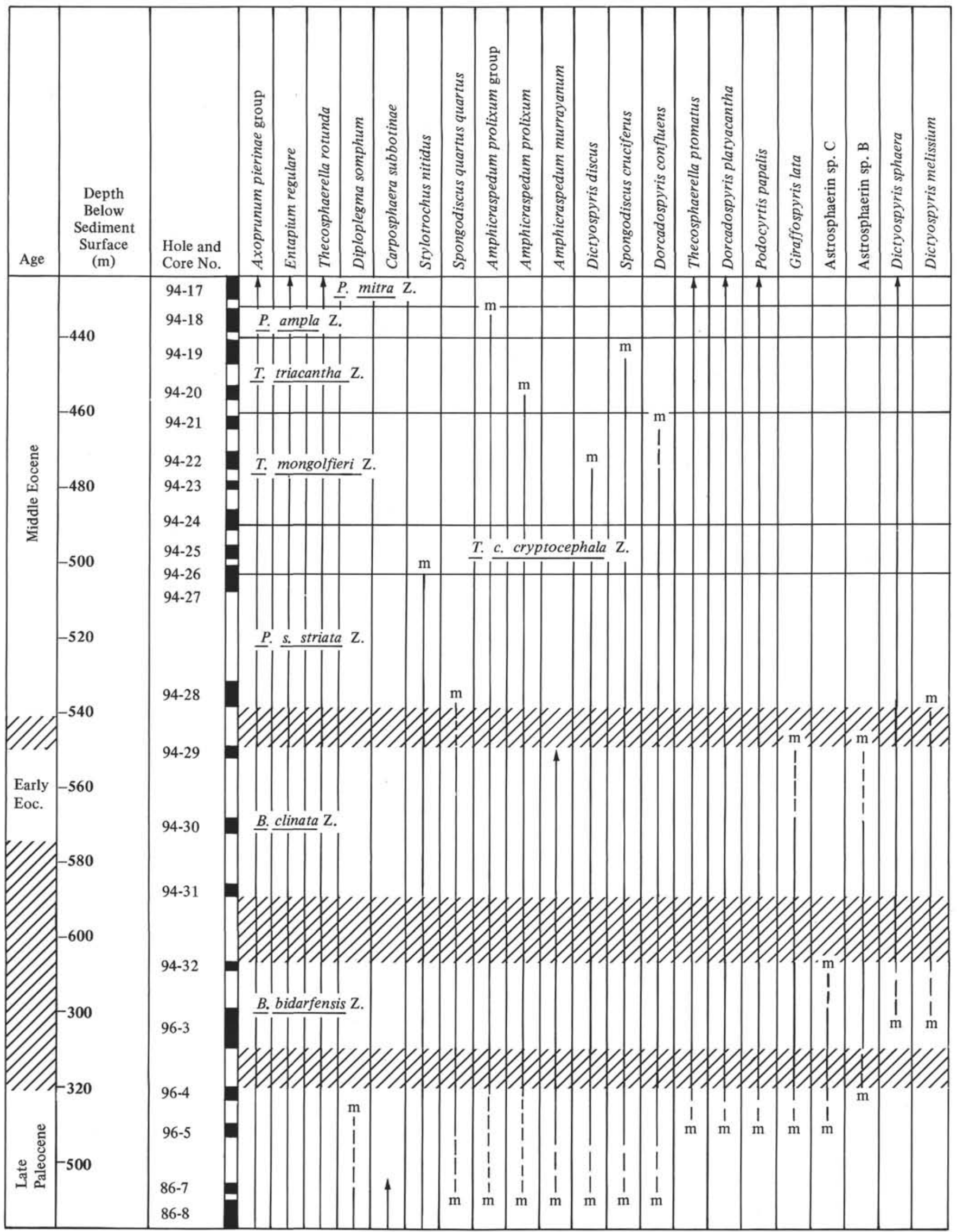

Figure 5. (Continued). 
A. SANFILIPPO, W. R. RIEDEL

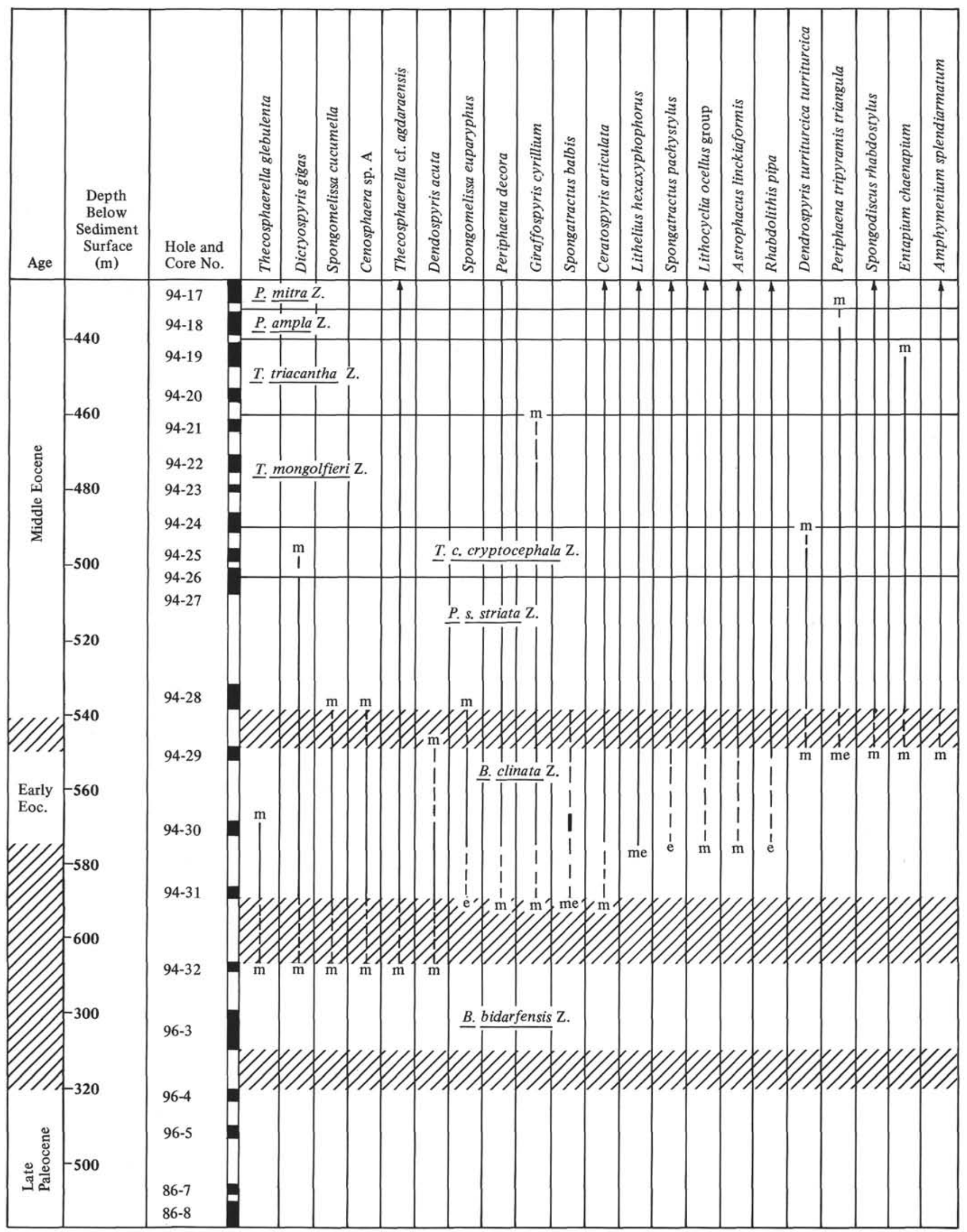

Figure 5. (Continued). 


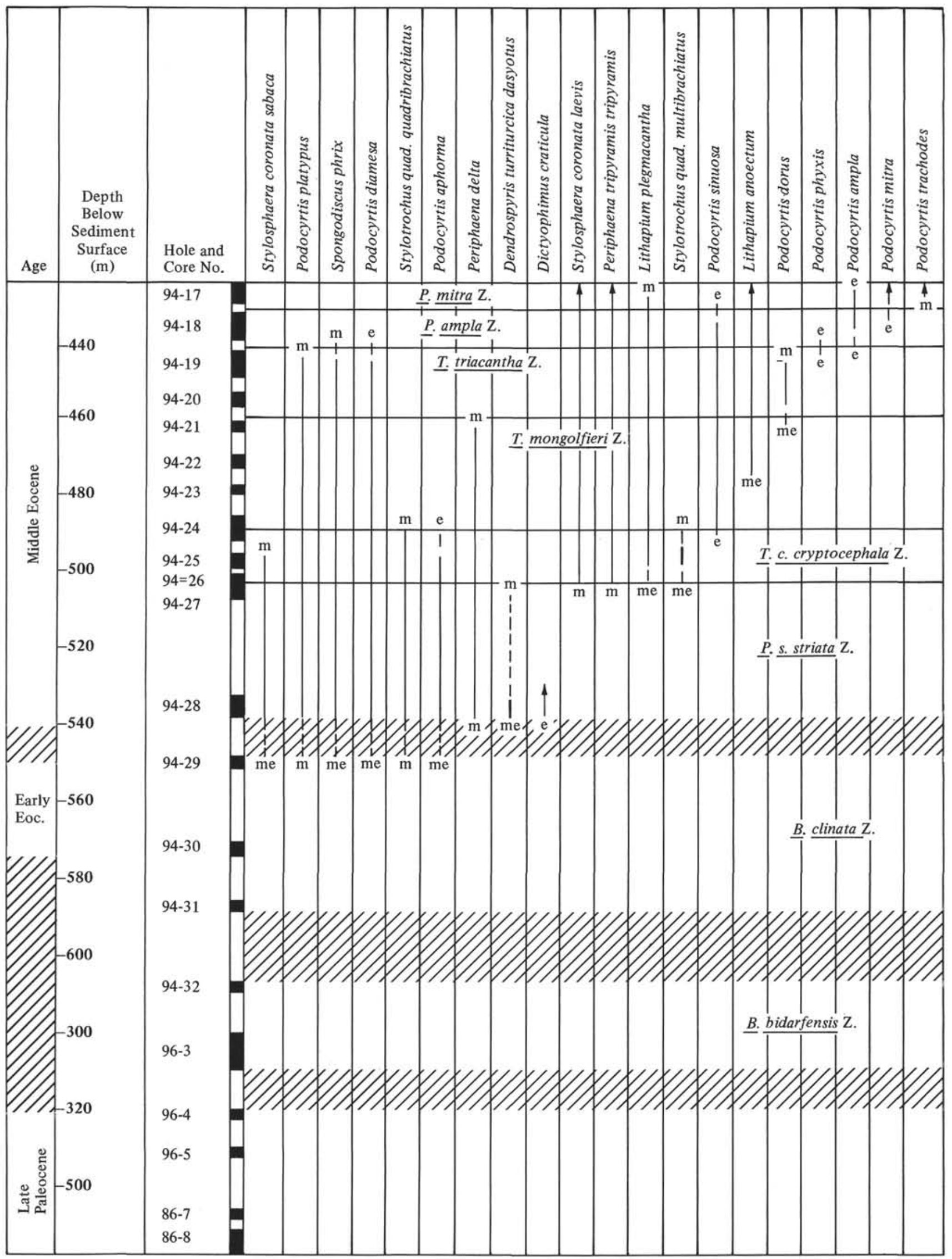

Figure 5. (Concluded). 


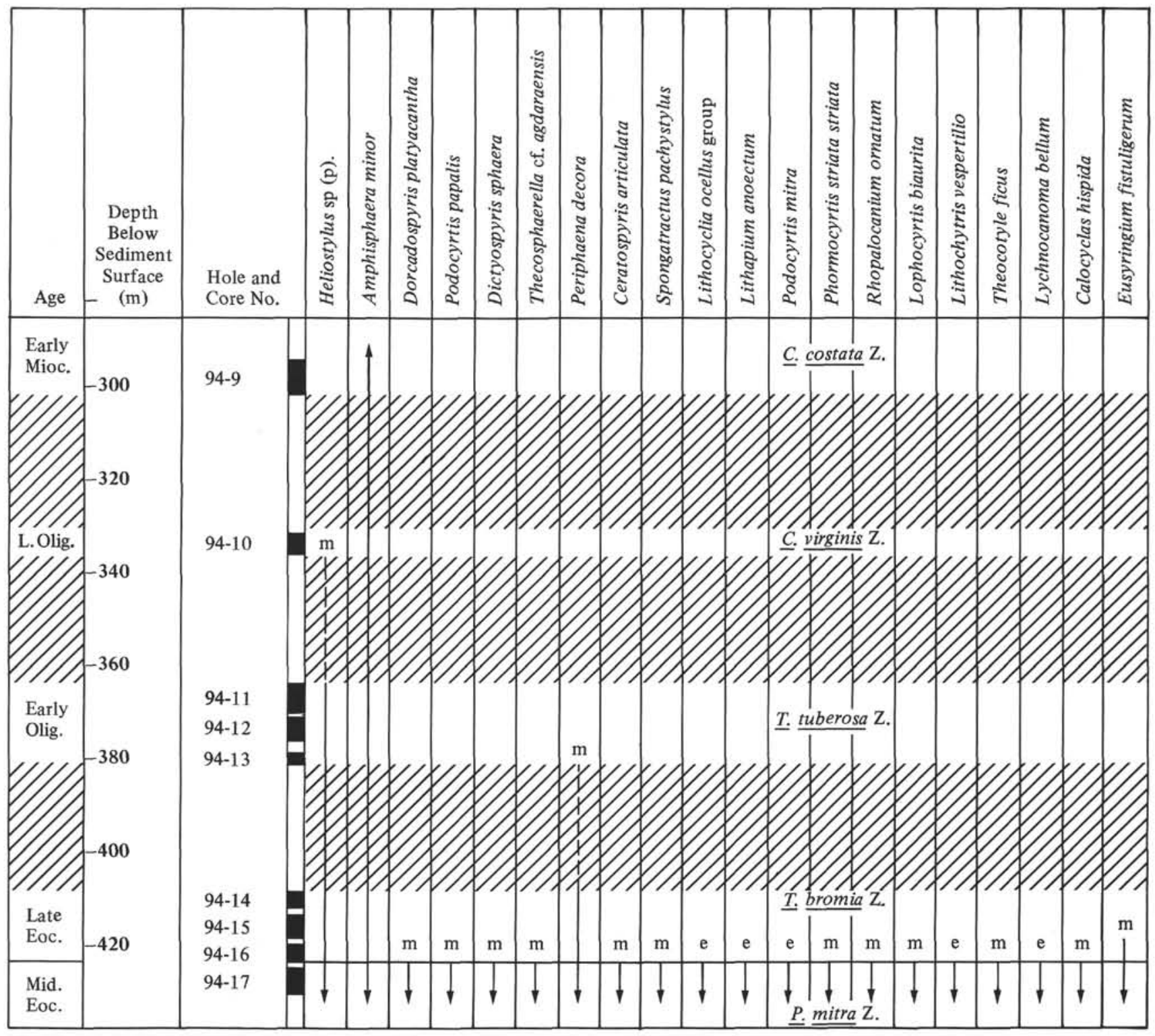

Figure 6. Radiolarian ranges for part of middle Eocene through early Miocene.

\section{8(2)Ka. Lithapium anoectum Riedel and Sanfilippo \\ (Plate 24, Figures 6,7)}

Lithapium (?) anoectum Riedel and Sanfilippo, 1970, p. 520, pl. 4, figs. 4,5 .

Remarks: The stratigraphic range of this species relative to that of L. plegmacantha seems to indicate that it evolved from the latter, though the ranges of the morphotypes overlap considerably.

\section{$8(2) \mathrm{Kb}$. Lithapium mitra (Ehrenberg)}

Cornutella mitra Ehrenberg, 1873, p. 221; 1875, pl. 2, fig. 8. Lithapium (?) mitra (Ehrenberg) (?), Riedel and Sanfilippo, 1970 p. 520 , pl. 4 , figs. 6,7 .

\section{8(2)Kc. Lithapium plegmacantha Riedel and Sanfilippo \\ (Plate 3, Figures 1,2; Plate 24, Figures 8,9)}

Lithapium (?) plegmacantha Riedel and Sanfilippo, 1970, p. 520, pl. 4, figs. $2,3$.
Remarks: It is now possible to add two observations to the original description of this species. The original description indicated that the bladed external spines are randomly distributed. This is to some extent true, but we have never found any arising from a large area of the shell opposite the conical protuberance. Secondly, the cortical shell structure in many specimens from the earlier part of the range of this species is not everywhere a simple lattice, but is made up of smaller pores superimposed upon larger ones, in a zone intermediate between the conical projection and the opposite pole (Plate 24, Figure 8).

Unlikely though it may seem at first, there are some indications that Lithapium plegmacantha may have evolved from Entapium chaenapium (see Plate 23, Figures 9-12) (which has a rather coarse-pored, spherical cortical shell joined to a delicate, pyriform medullary shell by bladed bars which continue externally as spines), by the medullary shell moving in the direction of its narrow end so as to protrude from the cortical shell and become fused with its meshwork. The indications favoring this hypothesis are the following:

1) Shortly before the earliest appearance of $L$. plegmacantha, most specimens of $E$. chaenapium have the medullary shell open at its broad end, and in this region the bars connecting it with the cortical shell 


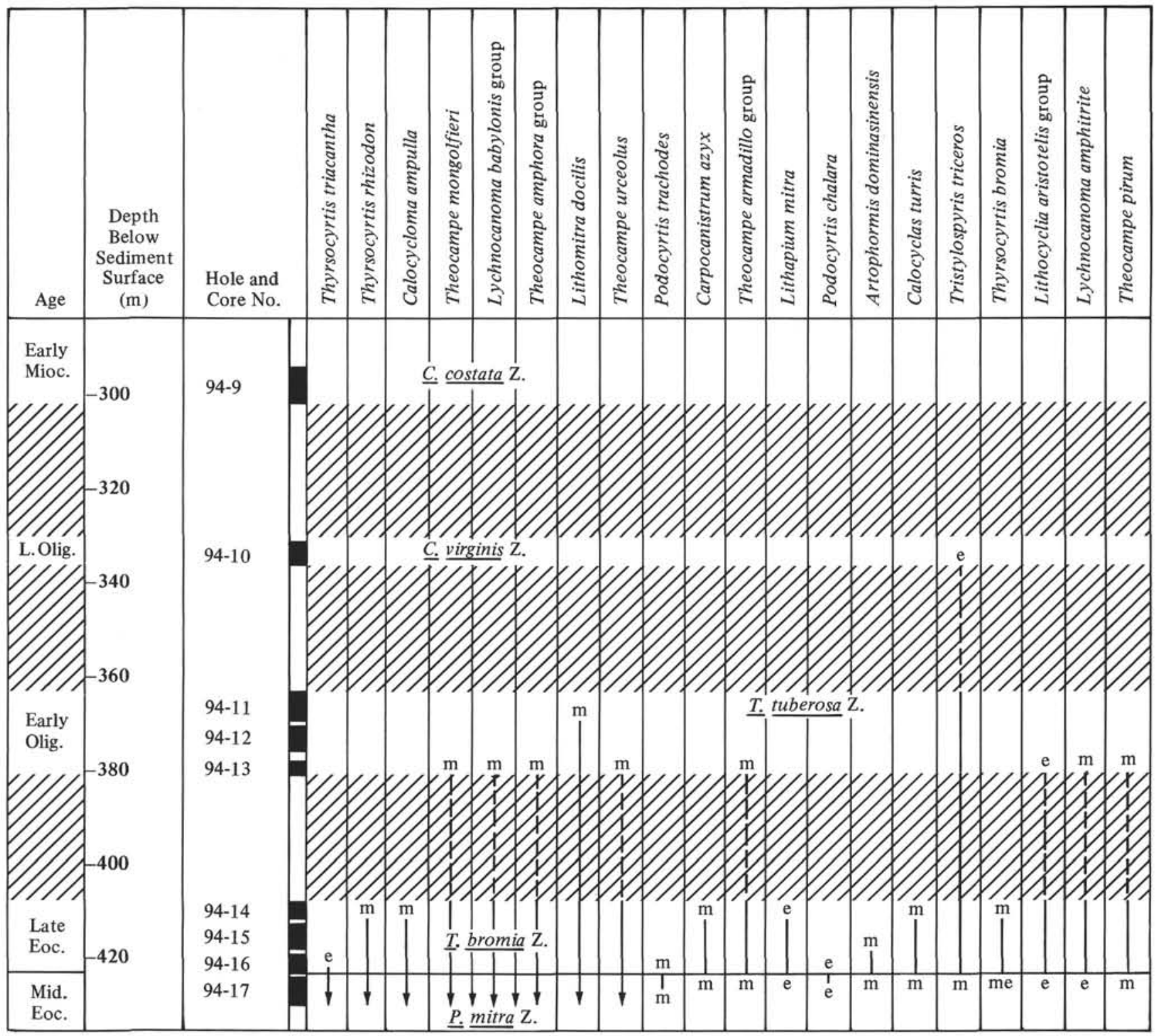

Figure 6. (Continued).

are atrophied, while the bars closer to the narrow end remain strong and bladed.

2) When external spines (additional to the "apical" spine) are present in $L$. plegmacantha, they tend to occur not in the area opposite the conical protuberance, but about a third of the distance "upward" (toward the "apical" end), i.e., in a zone corresponding to the "lowest" of the strong bars connecting the medullary and cortical shells in E. chaenapium as described in (1), above.

3) The subdivided pores of the earliest specimens of L. plegmacantha occur in a zone just "below" the conical protuberance, i.e., in the region where two sets of pores might tend to form if the hypothesis of outward migration of the medullary shell is valid.

This process of outward migration of an inner shell may be paralleled in Oropagis dolium Friend and Riedel (1967), though in that species it is not yet possible to demonstrate that the process occurred as a progression through time.

It must be admitted that one of the principal motivations for the development of this hypothesis is the fact that no other likely ancestor for L. plegmacantha was found in the assemblages immediately below its earliest occurrence. However, this species may have evolved by a completely different route, in another part of the world ocean, and it may eventually prove not to be necessary to invoke a mechanism so dramatic as outward migration of a medullary shell.

\section{8(2)L. Genus LITHOMESPILUS Haeckel}

Lithomespilus Haeckel, 1881, p. 450. Type species (indicated by Campbell, 1954, p. 69) Lithomespilus phloginus Haeckel (1887, p. 302, pl. 14, fig. 16).

Druppocarpus Haeckel (1887, p. 311), with the type species Druppocarpus ananassa Haeckel (1887, p. 311) designated by Campbell (1954, p. 70), may be a synonym, but its cortical and medullary shells are probably connected by straight bars, and there is no indication that the spines are grouped at the poles.

\section{8(2)La. Lithomespilus mendosa (Krasheninnikov) \\ (Plate 4, Figures 6, 7; Plate 24, Figures 10, 11)}

Ellipsidium (?) mendosum Krasheninnikov, 1960, p. 281, pl. 1, fig. 14. Ellipsidium cultum Borisenko, 1960b, p. 224, pl. 3, fig. 4.

Description: Cortical shell inflated-ellipsoidal, almost spherical, with shell wall of very variable thickness. Most specimens, with thinner walls, have usually well-separated, subcircular pores irregular in size and arrangement, and less common specimens with thick walls have pores which are simple inward, subdivided near the outer surface of the shell. 


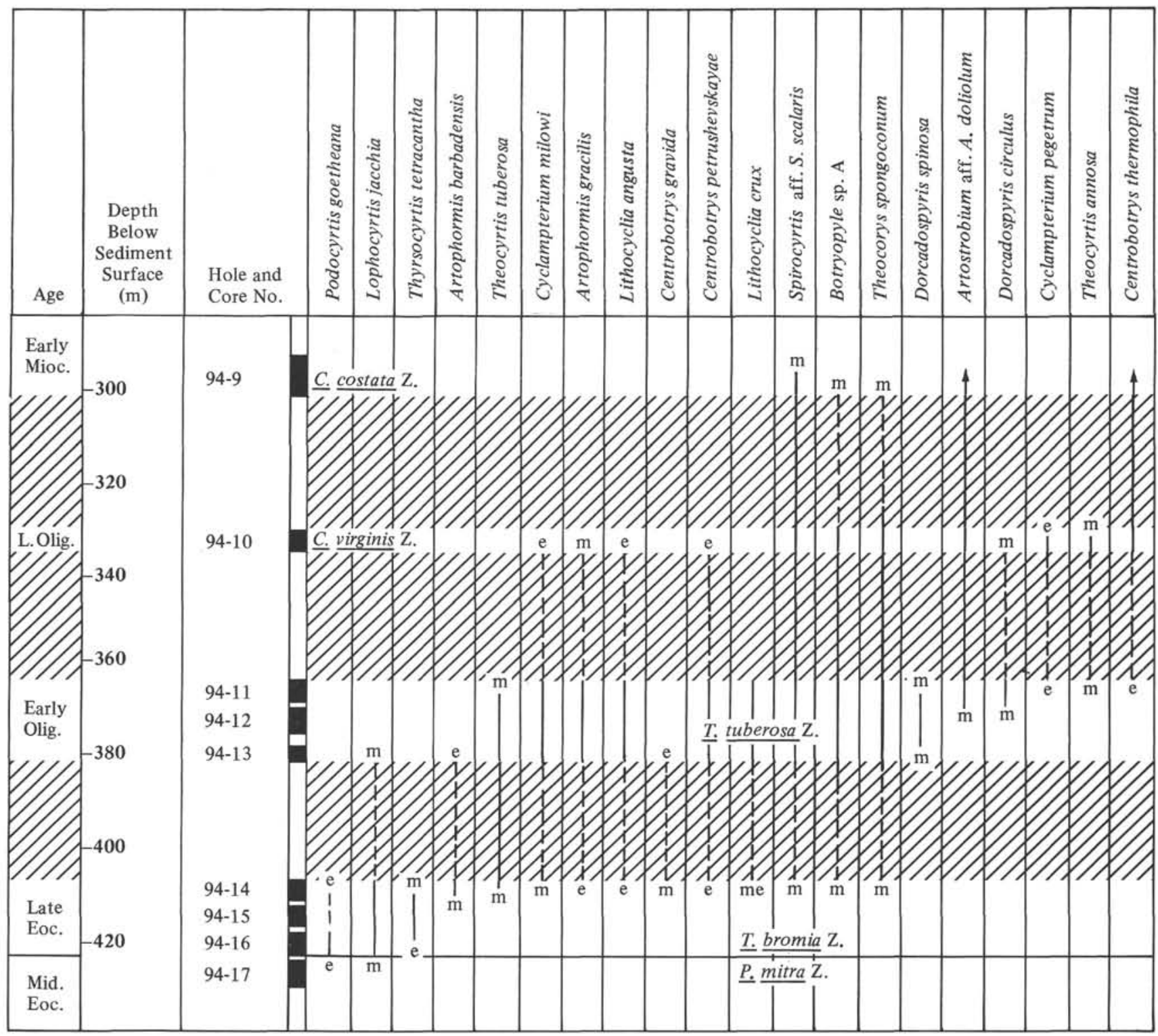

Figure 6. (Continued).

Shell surface generally thorny, with a group of long, conical thorns at each pole. Many specimens have no internal structures, but some show a large medullary structure which in one broken specimen is seen to consist of an irregularly shaped, very delicate, large-meshed shell joined to the cortical shell by numerous bars which branch and anastomose.

Measurements (based on 30 specimens from 86-7, CC and 86-8-3). Maximum diameter of cortical shell $120-200 \mu$.

Remarks: This species is distinguished principally by the group of larger thorns at each pole, and when it becomes better known the internal structure may prove to be diagnostic. The names in synonymy are both of 1960, and we have chosen Krasheninnikov's because his description emphasizes the bipolar grouping of thorns.

\section{8(2)M. Genus SPONGATRACTUS Haeckel}

Spongatractus Haeckel, 1887 , p. 350 . Type species (indicated by Campbell, 1954, p. 74) Spongosphaera pachystyla Ehrenberg (1873, p. 256; 1875 , pl. 26, fig. 3).

Spongoxiphus Haeckel, 1887, p. 353. Type species (designated by Campbell, 1954, p. 74) Spongoxiphus prunococcus Haeckel (1887, p. 354, pl. 17 , figs. 12,13 )

\section{8(2)Ma. Spongatractus balbis Sanfilippo and Riedel, new species}

(Plate 2, Figures 1-3; Plate 25, Figures 1,2)

Description: Cortical shell ellipsoidal, thick-walled, with subcircular pores (approximately $8-13$ on the half-equator), joined to the double medullary shell by bars lying approximately in the equatorial plane, and usually two bars collinear with the polar spines. On the surface of the cortical shell are one to three layers of meshwork formed by connection of the distal ends of small superficial thorns. Two-bladed polar spines are somewhat variable in form and size, but are commonly robust, about half as long as the cortical shell, with a change in contour from parallel-sided proximally to tapered distally.

Measurements (based on 25 specimens from 94-28-5; 94-29, CC; and 94-30-1). Major diameter of cortical shell (excluding the external layers) $105-150 \mu$, its minor diameter $65-145 \mu$. Maximum diameter of outer medullary shell $30-50 \mu$.

Remarks: This species is distinguished from the Axoprunum pierinae group by the external meshwork on the cortical shell. S. pachystylus, with 


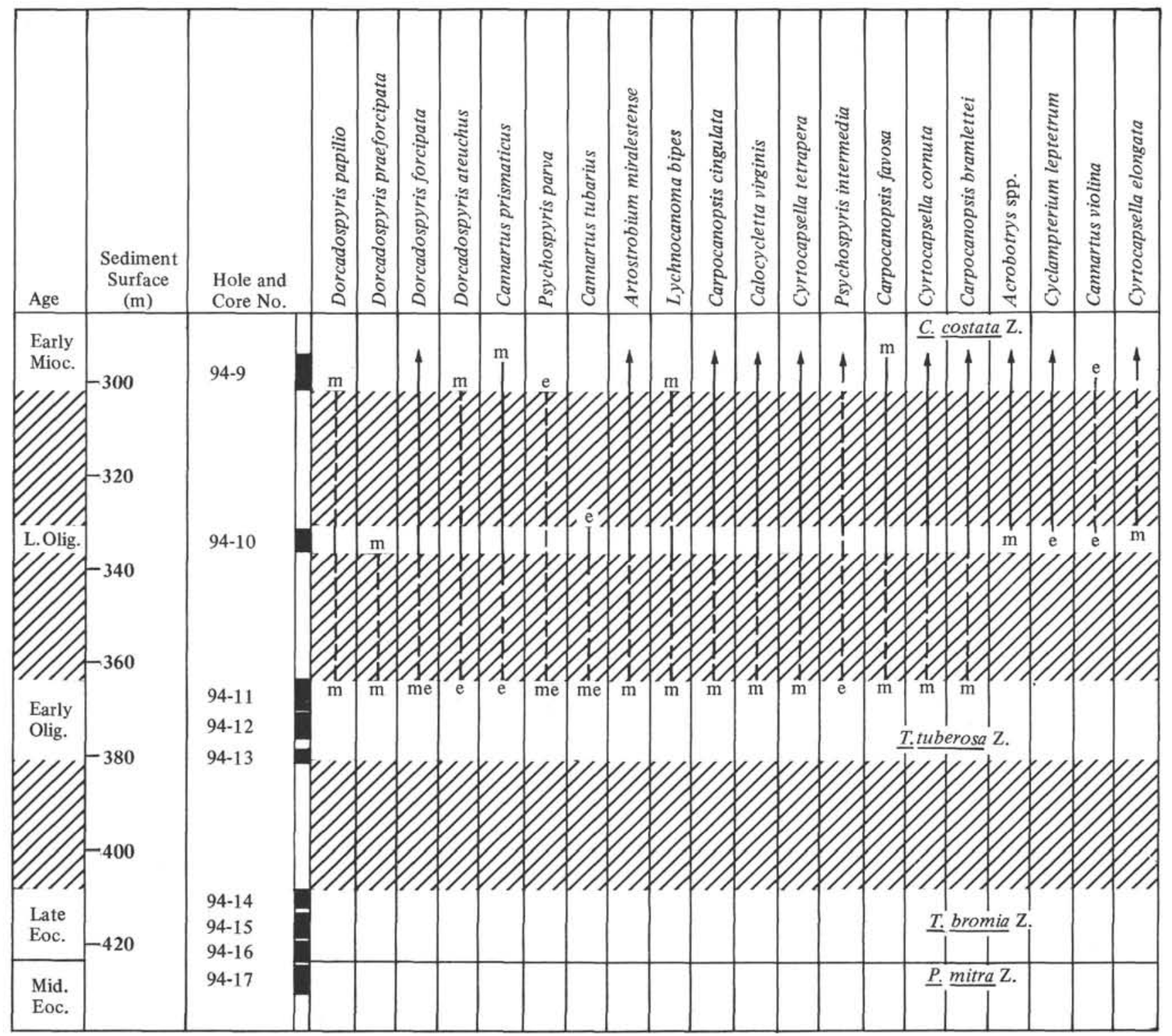

Figure 6. (Continued).

a greater development of external spongy meshwork, evidently evolved from the $A$. pierinae group via this species.

The specific name is the Greek balbis (starting-point), used as a noun in apposition.

\section{8(2)Mb. Spongatractus Pachystylus (Ehrenberg) (Plate 2, Figures 4-6; Plate 25, Figure 3)}

Spongosphaera pachystyla Ehrenberg, 1873, p. 256; 1875, pl. 26, fig. 3. Spongoxiphus prunococcus Haeckel, 1887, p. 354, pl. 17, figs. 12, 13.

Spongoprunum markleyense Clark and Campbell, 1942, p. 37, pl. 4, fig. 1 .

Spongoprunum markleyense ovum Clark and Campbell, 1942, p. 37, pl. 4 , fig. 5 .

Spongoprunum densum Clark and Campbell, 1942, p. 37, pl. 4, fig. 3.

Remarks: This species evidently arose from Spongatractus balbis, from which it is distinguished by greater development of the spongy outer layer. Its spines are constantly robust, and show a characteristic change in contour from parallel-sided proximally to tapered distally.
Reexamination of topotypic assemblages reveals that the forms described by Clark and Campbell are not solid spongy shells, but are in fact similar in structure to Ehrenberg's species.

\section{8(2)N. Genus STYLOSPHAERA Ehrenberg}

Stylosphaera Ehrenberg, 1847a, chart to p. 385. Type species (by monotypy) Stylosphaera hispida Ehrenberg (1854a, p. 246; 1854b, pl. 36, fig. 26, C right).

Genera with rather similar type species, and which may be synonyms, include -

Druppatractus Haeckel, 1887, p. 324. Type species (designated by Frizzell and Middour, 1951, p. 20) Druppatractus hippocampus Haeckel (1887, p. 324 , pl. 16 , figs. 10,11$)$.

Druppatractylis Haeckel, 1887 , p. 325 . Type species (designated by Campbell, 1954, p. 71) Druppatractus ostracion Haeckel (1887, p. 326 , pl. 16 , figs. 8,9$)$.

Ellipsoxiphetta Haeckel, 1887, p. 296. Type species (designated by Campbell, 1954, p. 69) Ellipsoxiphus flosculus Haeckel (1887, p. 296). 


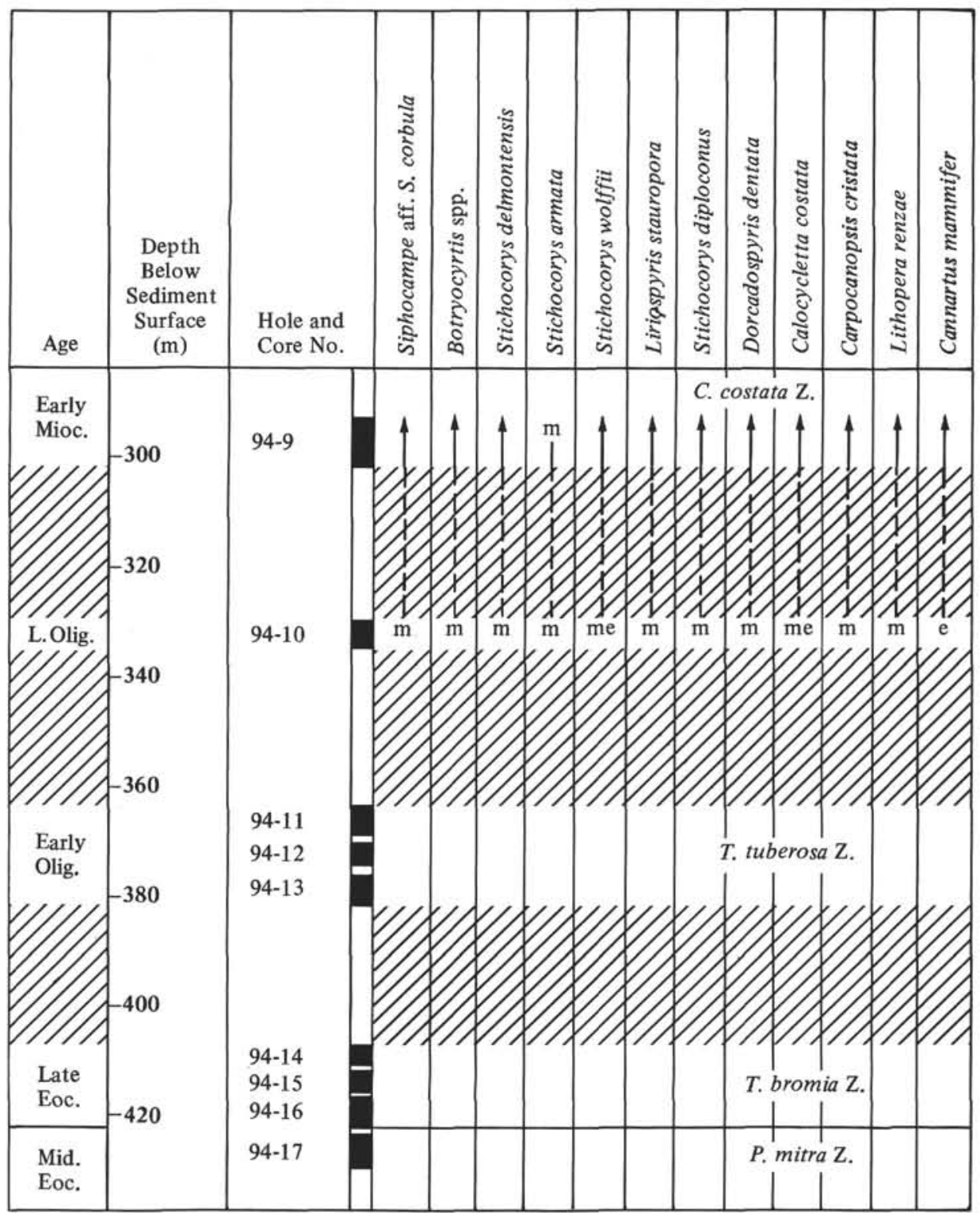

Figure 6. (Concluded).

The type species of Stylosphaerantha Haeckel (1887, p. 133), Stylosphaera calliope Haeckel (1887, p. 134, pl. 16, fig. 6 - designated by Campbell, 1954, p. 53), is somewhat similar, though with a spherical cortical shell. The Miocene type species (by monotypy) of Cromydruppocarpus Campbell and Clark (1944, p. 20), Cromydruppocarpus esterae Campbell and Clark (1944, p. 20, pl. 2, figs. 26-28), may have had a different evolutionary origin.

\section{8(2)Na. Stylosphaera coronata coronata Ehrenberg (Plate 1, Figures 13-17; Plate 25, Figure 4)}

Stylosphaera coronata Ehrenberg, 1873, p. 258; 1875, pl. 25, fig. 4. Druppatractus trichopterus Clark and Campbell, 1942, p. 34, pl. 5, fig. 4.

?Lithatractus hederae Clark and Campbell, 1942, p. 33, pl. 5, fig. 3.

?Druppatractus polycentrus Clark and Campbell, 1942, p. 35, pl. 5, fig. 19.

?Druppatractus parasagittatus Middour, in Frizzell and Middour, 1951, p. 21, pl. 2, figs. 11, 12.

Description: Cortical shell ellipsoidal, thick-walled, with pores subcircular, generally rosette-shaped (distance between centers approximately $11-17.5 \mu$ ). At each pole of the cortical shell is a heavy, bladed spine-one of them evenly tapered, approximately as long as the cortical shell, and the other shorter, with its outline commonly subparallel proximally and abruptly tapered distally. Medullary shell delicate, pyriform, with its axis usually coincident with that of the cortical shell, joined to the cortical shell by about eight or more bars, of which the two collinear with the external spines are the strongest.

Measurements (based on 30 specimens from 94-17-2, 94-22-4, 94-26-2, and 96-3-5). Major diameter of cortical shell $75-115 \mu$, its minor diameter 75-110 $\mu$. Width of medullary shell $27.5-37.5 \mu$.

Remarks: Occasional specimens with two spines at one pole are excluded from this species (see remarks on Stylosphaera goruna).

Somewhat similar forms in the literature include that identified as Druppatractus ostracion Haeckel by Brandt (1935, p. 52, pl. 9, figs. 5, 6), and that identified as Druppatractus santaeannae (Campbell and Clark) by Kozlova and Gorbovets (1966, p. 63, pl. 9, figs. 7-9).

\section{8(2)Nb. Stylosphaera coronata laevis Ehrenberg} (Plate 1, Figure 19; Plate 25, Figures 5,6)

Stylosphaera laevis Ehrenberg, 1873, p. 259; 1875, pl. 25, fig. 6 .

Description: Shell resembling Stylosphaera coronata coronata, but with cortical shell thinner-walled and with smoother surface, and spines longer, evenly tapering. 
Measurements (based on 30 specimens from 94-17-2 and 94-22-4). Major diameter of cortical shell $75-100 \mu$, its minor diameter $65-80 \mu$. Length of the longer spine $70-125 \mu$.

Remarks: This subspecies evidently developed from $S$. coronata coronata, with which it cooccurs. Its limits can be only morphotypically defined.

\section{$8(2)$ Nc. Stylosphaera coronata sabaca Sanfilippo and Riedel, new subspecies}

(Plate 1, Figure 18; Plate 25, Figures 7,8)

Description: Shell resembling that of $S$. coronata coronata, but with cortical shell superficially thorny and more nearly spherical, and its wall "double" as a result of expansion of the pores between the inner and outer surfaces.

Measurements (based on 20 specimens from 94-26-2 and 94-28-2). Major diameter of cortical shell $110-135 \mu$, its minor diameter $105-130 \mu$.

Remarks: The origin of the "double" cortical shell in this form is not in the usual manner, by joining of the branched ends of short spines as in the forms with "tertiary shells" described by Mast (1910), but by the bars separating the pores becoming thinner between the inner and outer surfaces of the thick shell wall. There is a superficial similarity to Cromyatractus tetracelyphus Haeckel (1887, p. 335, pl. 15, figs. 1, la).

The subspecific name is derived from the Greek sabakos (feeble, rotten), an allusion to the apparent breakdown of the wall of the cortical shell.

\section{8(2)Nd. Stylosphaera goruna Sanfilippo and Riedel, new species}

(Plate 1, Figures 20-22; Plate 25, Figures 9,10)

Description: Cortical shell ellipsoidal, of variable wall thickness, with pores subcircular or occasionally rosette-shaped, of irregular size and arrangement (distance between centers approximately 9-17.5 $\mu$ ). From the surface of the cortical shell arise several strong, blades spines commonly a long one at or near each pole (its length approaching that of the cortical shell) and 1-3 shorter ones scattered over each halfellipsoid. Medullary shell single, delicate, pyriform, with its axis not aligned with the longer spines (and therefore commonly appearing to be circular in outline). Cortical and medullary shells joined by six or more radial bars, some of which are collinear with some of the external spines. In the older assemblages examined, many specimens have no medullary shells nor internal bars.

Measurements (based on 20 specimens from 86-7, CC; 86-8, CC; and 96-3-1). Major diameter of cortical shell $65-105 \mu$, its minor diameter $60-95 \mu$. Width of medullary shell $25-35 \mu$.

Remarks: This species is distinguished principally by possessing two or more strong spines on each half-ellipsoid. Excluded from the present definition are rare specimens resembling Stylosphaera coronata but with two spines at one pole and one at the other (Plate 25, Figure 11), and a small, single-shelled ellipsoidal form having sparse, irregularly distributed pores and a group of thorns at each pole (Plate 25, Figure 12).

The specific name is an arbitrary combination of letters, used as a noun in apposition.

\section{8(2)O. Genus THECOSPHAERA Haeckel}

Thecosphaera Haeckel, 1881, p. 452. Type species (indicated by Campbell, 1954, p. 50) Thecosphaera triplodictyon Haeckel (1887, p. 79). Campbell (1951, p. 528) proposed a new genus Thecotapus to include the single species that Rüst (1885) assigned to Thecosphaera. The legality of that procedure is questionable, but until the true relationships of the type species of Thecosphaera are better known it seems advisable to continue to use that generic name in the conventional sense.

\section{8(2)Oa. Thecosphaera larnacium Sanfilippo and Riedel, new species}

(Plate 3, Figures 4-6; Plate 25, Figures 13,14)

Description: Double spherical medullary shell connected to cortical shell by six rather robust, bladed bars situated approximately at right angles. Cortical shell tending to be cubic, as a result of flattened faces being developed on the sphere at the points of its junction with the six internal bars. Cortical shell wall usually rather thick, with surface roughened by minute thorns arising from the intervening bars; its pores (especially in thicker-walled specimens) tending to be rosette-shaped. Some specimens have short thorns on the cortical shell in line with the internal bars, and some have stronger, bladed spines arising from the rounded corners of the "cubic" cortical shell.

Measurements (based on 30 specimens from $86-8, \mathrm{CC}$; $94-32 \mathrm{CC}$; and 96-3-1). Diameter (diagonal) of cortical shell 120-220 $\mu$, of outer medullary shell $35-55 \mu$.

Remarks: This species is distinguished from others of the genus by the tendency to a cubic shape, presence of six regularly arranged internal bars, and absence of strong external spines collinear with the internal bars. The pores on the cortical shell are much smaller than in Carposphaera buxiformis Clark and Campbell (1942, p. 21, pl. 5, fig. 20).

The species name (larnakion, a small box) is used as a noun in apposition.

\section{8(2)P. Genus THECOSPHAERELLA Haeckel}

Thecosphaerella Haeckel, 1887, p. 80. Type species (designated by Campbell, 1954 , p. 50 ) Haliomma inerme Haeckel (1860a, p. 815; Actinomma inerme, Haeckel, 1862, p. 440, pl. 24, fig. 5).

\section{8(2)Pa. Thecosphaerella sp. cf. T. Agdaraensis (Mamedov) (Plate 2, Figures 7-9; Plate 25, Figure 15)}

cf. Sphaerostylus agdaraensis Mamedov, 1969, p. 96, pl. 2, figs. 1, 2.

Description: Double medullary shell joined to cortical shell by approximately 6-9 rather robust, bladed bars. Cortical shell thick-walled, tending to be flattened at the points of junction with the internal bars. Pores of cortical shell usually rosette-shaped, and its surface roughened by small thorns. One to three robust, bladed spines on cortical shell are not collinear with internal bars.

Measurements (based on 30 specimens from 94-28-5 and 94-30-2). Maximum diameter of cortical shell $135-205 \mu$, of outer medullary shell $40-70 \mu$.

Remarks: This species is distinguished from all others of the genus treated here by the possession of strong external spines. When only two spines are present, these are commonly disposed opposite one another, and the specimen then resembles an Axoprunum; however, in this species there are no internal bars collinear with the two spines. In the original illustration of Sphaerostylus agdaraensis, external spines are shown as being collinear with internal bars.

\section{$8(2) \mathrm{Pb}$. Thecosphaerella glebulenta Sanfilippo and Riedel, new species \\ (Plate 3, Figures 12, 13; Plate 26, Figure 1)}

Description: Double medullary shell connected to cortical shell by approximately 7-10 bars. At their points of junction with the cortical shell, the latter is as if drawn inward in relation to the other parts of the shell, which thus has an irregular, lumpy appearance. Cortical shell wall moderately thick, with pores tending to be rosette-shaped and surface greatly roughened by small thorns which are joined by lamellar extensions of the intervening bars. No external spines.

Measurements (based on 25 specimens from 94-30-1, 94-30-2 and 94-31, CC). Maximum diameter of cortical shell $140-195 \mu$, of outer medullary shell $50-70 \mu$.

Remarks: This species is distinguished from $T$. cf. agdaraensis by the lack of external spines, and from all other members of the genus by its more irregular form.

The specific name is derived from the Latin adjective glebulentus, lumpy.

\section{8(2)Pc. Thecosphaerella ptomatus Sanfilippo and Riedel, new species \\ (Plate 3, Figures 14-18; Plate 26, Figure 2)}

Description: Cortical shell spherical, generally rather thin-walled, with pores subcircular (very rarely rosette-shaped in late specimens) and variable in size, and with surface thorny and commonly having a few larger thorns with broad bases. Medullary shell thin-walled, double (the inner one commonly attached directly to the outer), the outer one directly attached to the cortical shell and consequently appearing to be flattened on that side. There are few or no bars connecting the outer medullary shell with the cortical shell, but the surface of the former often bears numerous, very delicate spines radiating from its free surface.

Measurements (based on 30 specimens from 94-22-4, 94-30-2, and 96-3-5). Diameter of cortical shell $115-185 \mu$, of outer medullary shell $35-60 \mu$. Distance between centers of pores of cortical shell $9-15 \mu$. 
Remarks: This species is distinguished from Diploplegma somphum by the cortical and medullary shells not being spongy, and from other species by the medullary shell being directly attached to the cortical shell. Actinomma undosa Kozlova (Kozlova and Gorbovets, 1966, p. 59, pl. 9, figs. 1-4) is somewhat similar, but the medullary shells are not described as being eccentrically positioned in that species.

The specific name (ptomatos, that which has fallen) is used as a noun in apposition.

\section{8(2) Pd. Thecosphaerella rotunda (Borisenko)}

(Plate 3, Figures 7-11; Plate 26, Figure 3)

Thecosphaera rotunda Borisenko, 1960b, p. 222, pl. 1, fig. 3; pl. 3, figs. $2,3$.

Description: Double medullary shell joined to cortical shell by approximately 6-9 bars irregularly disposed. Cortical shell (especially in late specimens) very thick, the sphere slightly irregular due to its being flattened at the points of junction with the internal bars. Pores of the cortical shell tend to be rosette-shaped, and its surface is roughened by small thorns.

Measurements (based on 30 specimens from 94-17-2, 94-28-5, and 94-30-2). Maximum diameter of cortical shell (excluding thorns) 145$205 \mu$, of outer medullary shell $45-70 \mu$.

Remarks: This species is distinguished from Thecosphaerella cf. agdaraensis by the absence of strong external spines, from Thecosphaera larnacium by the irregular disposition of the internal bars connecting medullary and cortical shells, and from Thecosphaerella glebulenta by the cortical shell being more spherical. Thecosphaerella rotunda may be identical with, or closely related to, Thecosphaera californica Clark and Campbell (1942, p. 22, pl. 4, fig. 7), but the pores of the cortical shell of that species are not described as tending to be rosette-shaped, and the outer surface is apparently not thorny.

\section{8(3). Family LITHELIIDAE Haeckel 1862}

\section{8(3)A. Genus LITHELIUS Haeckel}

Lithelius Haeckel, 1860 b, p. 843 . Type species (by monotypy) Lithelius spiralis Haeckel (1860b, p. 843 ; 1862, pl. 27, figs. 6, 7).

\section{8(3)Aa. Lithelius foremanae Sanfilippo and Riedel, new species}

(Plate 7, Figures 1-6; Plate 26, Figures 4, 5)

Description: Cortical shell spherical, robust, with pores subcircular, very irregular in size and arrangement, and with numerous thorns and/or cylindrical spines scattered over the surface. Internally is a spiral lattice of approximately 2-3 whorls increasing in breadth outwardly and connected with one another and with the cortical shell by numerous radial bars. The termination of this spiral structure joins with the cortical shell, though in some orientations the two appear to be separated by the width of the last whorl.

Measurements (based on 12 specimens from 86-8-3; 86-8, CC; 94-30-2; and 96-3, CC). Diameter of cortical shell 105-130 $\mu$.

Remarks: This species is characterized by the cortical shell being well differentiated from the internal spiral, even though the two are joined.

It is named for Helen P. Foreman of Oberlin College, in recognition of her valuable contributions in the field of radiolarian studies.

\section{8(3)Ab. Lithelius hexaxyphophorus (Clark and Campbell)} (Plate 7, Figures 7-9; Plate 26, Figures 6, 7)

Stylosphaera hexaxyphophora Clark and Campbell, 1942, p. 28, figs. 4, $5,7,11,12$.

Description: Cortical shell spherical, robust, with pores generally uniform on each specimen, but from specimen to specimen varying in size and from subcircular to rosette-shaped. Surface bears numerous small thorns, and few (approximately 6-30) long cylindrical spines with bladed bases, collinear with some of the internal bars. "Medullary" structure a delicate latticed spiral of approximately three whorls, occupying about a quarter to a half of the cortical shell diameter, joined to the cortical shell by numerous, thin radial bars.

Measurements (based on 30 specimens from 86-8, CC; 94-20-2; 94-24-2; and 94-30-2). Diameter of cortical shell 130-200 $\mu$. Distance

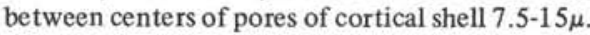

Remarks: This species apparently evolved from Lithelius foremanae, from which it is distinguished principally by the marked separation between internal spiral and cortical shell, and secondarily by generally larger size and heavier external spines. In large-pored specimens which we have examined from Clark and Campbell's locality A1793, the medullary structure is spiral.

In some assemblages, this species is accompanied by a superficially similar form (Plate 7, Figure 10; Plate 26, Figure 8) which has the medullary structure not spiral, but of two concentric spherical shells joined to the cortical shell by numerous thin bars.

\section{8(4). Family PHACODISCIDAE Haeckel 1881}

\section{8(4)A. Genus ASTROPHACUS Haeckel}

Astrophacus Haeckel, 1881, p. 457. Type species (indicated by Campbell, 1954 , p. 82) Astrophacus asteriscus Haeckel (1887, p. 453).

We apply this generic name to forms in which the cortical shell has rather large pores, and a surface which is roughened by ridges or thorns on the intervening bars, as opposed to the generally smaller pores and completely smooth surface of the cortical shell of the forms assigned to Periphaena. Although Haeckel describes the type species of Astrophacus as having a smooth cortical shell, our examination of specimens from Challenger Station 265 revealed the presence of indistinct ridges along the bars between pores, and minute, scattered thorns on its surface.

\section{8(4)Aa. Astrophacus linckiaformis (Clark and Campbell)} (Plate 7, Figures 11, 12; Plate 26, Figure 9)

Heliodiscus linckiaformis Clark and Campbell, 1942, p. 40, pl. 3, fig. 13.

Remarks: This species is characterized by rather large pores which generally have inwardly directed points indicating coalescence of 2-4 smaller pores. The surface of the cortical shell is often roughened by thorns arising at the junction of three intervening bars. Marginal spines (rarely connected by a narrow girdle) generally number from 7 to 13 . Diameter of cortical shell $155-230 \mu$, of medullary shell $45-75 \mu$. Number of pores on a radius 5-11.

\section{8(4)B. Genus HELIOSTYLUS Haeckel}

[?] Astrostylus Haeckel, 1887, p. 431. Type species (designated by Campbell, 1954, p. 81) Phacostylus caudatus Haeckel, 1887, p. 431, pl. 32, fig. 6 .

Heliostylus Haeckel, 1881, p. 457. Type species (designated by Campbell, 1954, p. 81) Sethostylus dentatus Haeckel, 1887, p. 429, pl. 34, fig. 1.

Phacostylus Haeckel, 1881, p. 457. Type species (indicated by Campbell, 1954, p. 80) Phacostylus amphistylus Haeckel, 1887, p. 430, pl. 31, fig. 12.

Stylodiscus Haeckel, 1887, p. 412. Type species (designated by Campbell, 1954, p. 78) Stylodiscus endostylus Haeckel, 1887, p. 413, pl. 31, fig. 11.

We apply this generic name to all phacodiscids in which two opposite bars connect the cortical and outer medullary shells. These two bars are often continued as strong marginal spines. The connection between the cortical and other medullary shells is not effected by these bars alone, but also by shorter bars to the central area of the discoidal cortical shell.

It is not yet possible satisfactorily to define species within this genus, and we therefore record all representatives as Heliostylus sp (p). (Plate 8, Figures 1-7; Plate 26, Figures 10-12; Plate 27, Figure 1).

\section{8(4)C. Genus PERIPHAENA Ehrenberg}

Astrophacomma Haeckel, 1887 , p. 454 . Type species (designated by Campbell, 1954, p. 82) Haliomma humboldti var. Bury (1862, pl. 8, fig. 3 at right; Astrophacus cingillum Haeckel, 1887, p. 454).

Heliodiscomma Haeckel, 1887, p. 448. Type species (designated by Campbell, 1954, p. 82) Heliodiscus cingillum Haeckel, (1887, p. 448 , pl. 33, fig. 7).

[?] Heliostaurus Haeckel, 1881, p. 457. Type species (designated by Campbell, 1954, p. 81) Sethostaurus cruciatus Haeckel (1887, p. 434, pl. 31, fig. 5).

Paracenodiscus Krasheninnikov, 1960, p. 284. Type species (by original designation) Paracenodiscus familiaris Krasheninnikov (1960, p. 284, pl. 2 , figs. $4 \mathrm{a}, 4 \mathrm{~b})$.

Periphaena Ehrenberg, 1873, p. 246. Type species (by monotypy) Periphaena decora Ehrenberg (1873, p. 246; 1875, pl. 28, fig. 6). 
Perizona Haeckel, 1881, p. 457. Type species (indicated by Campbell, 1954, p. 78) Perizona scutella Haeckel (1887, p. 427, pl. 32, fig. 7). Phacotriactis Sutton, 1896, p. 61. Type species (by monotypy) Phacotriactis triangula Sutton (1896, p. 61, fig. 3).

[?] Sethostylus Haeckel, 1881, p. 457. Type species (indicated by Campbell, 1954, p. 81) Sethostylus distyliscus Haeckel (1887, p. 428, pl. 31, fig. 9).

Staurodiscus Krasheninnikov, 1960, p. 289. Type species (by monotypy) Staurodiscus primus Krasheninnikov (1960, p. 289, pl. 2, figs. 11a, 11b).

Triactis Haeckel, 1881 , p. 457 , and Triactiscus Haeckel, 1887, p. 432. See discussion of type species by Riedel and Sanfilippo (1970, p. 521). Loeblich and Tappan (1961, p. 224) indicate that Triactis Haeckel is a homonym of Triactis Klunzinger, 1877.

We have grouped under this generic name all forms in which the cortical shell has a smooth surface and numerous small pores. Shells may be circular, triangular or elliptical in outline, and the margin may be provided with a variable number of spines (or none), or a girdle, or spines joined by a girdle.

Several phyletic lines may be present within this genus, but these do not seem to be reflected by the Haeckelian genera, and the forms included here are apparently more closely related to each other than to those which are placed in the genus Astrophacus.

8(4)Ca. Periphaena decora, Ehrenberg

(Plate 8, Figures 8-10; Plate 27, Figures 2-5)

Periphaena decora Ehrenberg, 1873, p. 246; 1875, pl. 28, fig. 6; Riedel 1957 b, p. 258 , pl. 62 , fig. 1 .

Haliomma humboldtii Ehrenberg, 1847b, p. 55; 1854b, pl. 36, fig. 27; 1875 , pl. 27 , fig. 3 .

Heliodiscus humboldti (Ehrenberg), Haeckel, 1887, p. 449; Riedel, 1957 b, p. 258 , pl. 62 , fig. 2.

Heliodiscus cingillum Haeckel, 1887, p. 448, pl. 33, fig. 7.

Periphaena cincta Haeckel, 1887 , p. 426 , pl. 33 , fig. 4 .

Perizona scutella Haeckel, 1887, p. 427, pl. 32, fig. 7.

Remarks: Under this name are included forms with a girdle of varying width, with or without projecting spines. Although we have not been able to find Periphaena cincta or Perizona scutella in material from Challenger Station 268, the occurrence of Periphaena decora there would be consistent with the fact that that sample contains some reworked Eocene forms (including Theocampe mongolfieri). No material from Challenger Station 274 is available to us for examination.

\section{$8(4) \mathrm{Cb}$. Periphaena delta Sanfilippo and Riedel, new species \\ (Plate 8, Figures 11,12; Plate 27, Figures 6,7)}

Description: Lenticular cortical shell with short, broad marginal spines. Cortical shell with thick wall, smooth surface, and numerous, small, cylindrical pores, with broad, delta-shaped, radially striated spines (usually six in number) arising as extensions of the margin. Medullary shell double.

Measurements (based on 20 specimens from Cores 94-22, 94-23, and 94-26). Diame ter of cortical shell (excluding spines) $130-205 \mu$, of outer medullary shell $40-55 \mu$. Number of pores on a radius of cortical shell $9-12 \mu$.

Remarks: This species is distinguished from all others of the genus by the short, broad, radially striated marginal spines. The radial striations are connected with the intervening bars of the pores at the margin of the cortical shell, as is common in members of this genus.

The specific name is an allusion to the shape of the marginal spines.

\section{8(4)Cc. Periphaena heliasteriscus (Clark and Campbell)} (Plate 9, Figures 1-6; Plate 27, Figures 8,9)

Heliodiscus heliasteriscus Clark and Campbell, 1942, p. 39, pl. 3, figs. $10,11$.

Heliodiscus cf. heliasteriscus Clark and Campbell, 1945, p. 22, pl. 5, fig. 5.

Heliodiscus pentasteriscus Clark and Campbell, 1942, p. 39, pl. 3, fig. 8 .

Remarks: This species is characterized by having many cylindrical pores perforating the smooth-surfaced cortical shell. Some individuals have pores a little larger than normal, but in these specimens the shell surface is never thorny or nodose, nor the pores rosette-shaped, as in Astrophacus linckiaformis. The diameter of the cortical shell is variable
$(140-230 u)$, as is the number and degree of development of the marginal spines (sometimes absent). Diameter of outer medullary shell $40-55 \mu$. Number of pores on a radius $9-14 \mu$.

\section{8(4)Cd. Periphaena tripyramis tripyramis (Haeckel) \\ (Plate 9, Figures 7-9)}

Triactis tripyramis Haeckel, 1887, p. 432, pl. 33, fig. 6 .

Triactis tripyramis tripyramis Haeckel, Riedel and Sanfilippo, 1970, p. 521 , pl. 4 , fig. 8 .

Remarks: As has been indicated previously (Riedel and Sanfilippo, 1970 , p. 521 ), this form is evidently very closely related to Haliomma triactis Ehrenberg. There is a strong possibility that Periphaena tripyramis tripyramis evolved from Periphaena heliasteriscus by a three-spined form of the latter becoming stabilized.

\section{8(4)Ce. Periphaena tripyramis triangula (Sutton)}

(Plate 9, Figures 10,11)

Phacotriactis triangula Sutton, 1896, p. 61.

Triactis tripyramis triangula (Sutton). Riedel and Sanfilippo, 1970, p. 521 , pl. 4 , figs. 9,10 .

\section{8(5). Family COCCODISCIDAE Haeckel 1862}

\section{8(5)A. Genus LITHOCYCLIA Ehrenberg}

Lithocyclia Ehrenberg 1847a, chart to p. 385; emend. Riedel and Sanfilippo, 1970, p. 522.

\section{8(5)Aa. Lithocyclia angusta (Riedel)}

Trigonactura augusta Riedel, 1959, p. 292, pl. 1, fig. 6.

Lithocyclia angustum (Riedel), Riedel and Sanfilippo, 1970, p. 522 , pl. 13, figs. 1,2 .

\section{8(5)AB. Lithocyclia aristotelis (Ehrenberg) group}

Astromma aristotelis Ehrenberg, 1847b, p. 55, fig. 10.

Lithocyclia aristotelis (Ehrenberg) group, Riedel and Sanfilippo, 1970, p. 522.

Remarks: There is now little doubt that Lithocyclia augusta evolved from the $L$. aristotelis group, which developed from the $L$. ocellus group.

8(5)Ac. Lithocyclia crux Moore

Lithocyclia crux Moore, 1971.

\section{8(5)Ad. Lithocyclia ocellus Ehrenberg group \\ (Plate 10, Figures 1,2)}

Lithocyclia ocellus Ehrenberg, 1854b, pl. 36, fig. 30; 1873, p. 240.

Lithocyclia ocellus Ehrenberg group, Riedel and Sanfilippo, 1970, p. 522 , pl. 5 , figs. 1,2 .

Remarks: Specimens in assemblages from near the lower limit of the range of this species-group tend more frequently to have spongy meshwork covering the cortical shell, than do later forms. These early forms do not show concentric zonation of the spongy flange, and commonly have 3-6 bladed spines originating at the periphery of the cortical shell.

This species-group represents the oldest member of the coccodiscids, and its evolutionary origin is therefore of importance. We have not been able to elucidate this satisfactorily, because the evolutionary change involved evidently occurred during the time represented by the gap in coring between Cores 94-29 and 94-30. However, it appears likely that the earliest member of the Lithocyclia ocellus group was very closely related to Periphaena tripyramis tripyramis, which has similar cortical and medullary shells, and bladed spines. Another, though less likely, possibility is that the L. ocellus group evolved from Spongatractus pachystylus by a change in form of the cortical shell from ellipsoidal to lenticular (with concomitant displacement of the axis of rotational symmetry through $90^{\circ}$ ), and increase in the number of spines.

\section{8(6). Family SPONGODISCIDAE Haeckel 1862, emend. Riedel 1967}

In this chapter we treat only a small proportion of the forms included in the Spongodiscidae in the sense of Riedel. We have attempted, though with little success, to group the species naturally into genera. It seems that the structure of the shell, especially in its central part (Kozlova, 1967a, 1967b) provides a more reliable basis for generic 
definition than does outward form, and therefore species with spongy arms have been placed in the same genus as discoidal forms having a similar internal structure. A measure of our lack of success in making natural groupings is the fact that we had to group under the name Spongodiscus a large number of forms, not all of which are closely related.

\section{8(6)A. Genus AMPHICRASPEDUM Haeckel}

Amphicraspedum Haeckel, 1881, p. 460 . Type species (indicated by Campbell, 1954, p. 86) Amphicraspedum maclaganium Haeckel (1887, p. 523 , pl. 45 , fig. 11$)$.

There is little likelihood that the forms listed below are closely related to the type species of this genus. They are included under this generic name merely as a matter of temporary convenience, until their relationships are better understood, because of Haeckel's assignment here of Amphicraspedum murrayanum.

\section{8(6)Aa. Amphicraspedum murrayanum Haeckel}

(Plate 10, Figures 3-6; Plate 28, Figure 1)

Amphicraspedum murrayanum Haeckel, 1887, p. 523, pl. 44, fig. 10.

Remarks: This species has an elliptical central body and two opposite arms. The central body has rings which are closely spaced internally and more widely spaced peripherally, traversed by numerous delicate radial spines. The arms originate within the central body, and are of dense spongy meshwork with distinct radial structure. Many of the radial elements protrude as thin spines from the ends of the arms, and each arm also bears a pair of divergent, terminal-lateral, longer, heavier spines. In some specimens, a narrow solid rim is formed along the sides of the arns from the bases of these strong spines.

Accompanying the earliest representatives of this species is an apparently related form with more pronounced radial structure and lacking the strong terminal-lateral spines (Plate 28, Figure 2). It seems possible that this form may be ancestral to A. murrayanum, and that the specimens of that species occurring in $96-4$ (CC) may represent contamination from higher in the hole.

The facts that this species was first described from a plankton sample, and that in our material it appears to have a restricted Paleogene range, cannot at present be reconciled.

\section{8(6)Ab. Amphicraspedum prolixum Sanfilippo and Riedel, new species \\ (Plate 10, Figures 7-11; Plate 28, Figures 3,4)}

Description: Elongated cylindrical skeleton, thickened at the ends, with or without a median swelling. Central structure in some specimens quite indistinct, consisting of only one or two rings, in others more distinct, with several closely spaced concentric rings. Two opposite arms greatly variable in length, consisting of a central core with pronounced longitudinal structure, surrounded by a more irregularly spongy sheath which also covers the central structure and distally merges into the expanded terminations of the arms. Spongy terminations of the arms either knoblike, conical, or flatly expanded, and in many specimens bearing few to many spines or thorns which can sometimes be seen to be continuations of the longitudinal structural elements of the arms.

Measurements (based on 20 specimens from Cores 94-23, 94-26, 94-31, 94-32 and 96-3). Length from center to end of spongy arm $235-830 \mu$. Because specimens with very long arms are more susceptible to breakage than are those with short arms, this range of measurements is not as meaningful as it is with most other species. Specimens with very long arms will not so often be sufficiently well preserved to show a complete arm, as will specimens with shorter arms.

Remarks: This species is distinguished from other members of the A. prolixum group by the longer arms and more pronounced longitudinal structure, and from Amphymenium splendiarmatum Clark and Campbell $(1942$, p. 46, pl. 1, figs. 12, 14) in that the latter has transversely chambered arms, not expanded terminally, and a less extensive spongy sheath. In rare specimens of $A$. prolixum, the expanded terminations of the arms are flanked by two spines similar to those of $A$. murrayanum.

The specific name is derived from the Latin prolixus (stretched out).

\section{8(6)Ac. Amphicraspedum prolixum Sanfilippo and Riedel group \\ (Plate 11, Figures 1-5; Plate 28, Figure 5)}

Description: Elongate spongy skeleton consisting of two arms with some indication of longitudinal structure (not necessarily prominent), and expanded terminations. Central structure greatly variable, from a very slight swelling associated with one or two concentric rings to an expanded disc with many closely spaced rings.

Measurements (excluding specimens of A. prolixum itself, and based on 30 specimens from 94-23-2; 94-26-2; 94-32, CC; and 96-3-6). Length from center to end of spongy arm $100-435 \mu$. Dimensions of $A$. prolixum are given in the description of that species.

Remarks: This group is defined so as to embrace A. prolixum and all other two-armed spongodiscids present in the Early Eocene assemblages with the exception of A.murrayanum, Amphymenium splendiarmatum, and some apparent relatives of Spongodiscus cruciferus with only two arms developed rather than four.

\section{8(6)B. Genus AMPHYMENIUM Haeckel}

Amphymenium Haeckel, 1881, p. 460. Type species (indicated by Campbell, 1954, p. 86) Amphymenium zygartus Haeckel (1887, p. 520, pl. 44, fig. 7)

\section{8(6)Ba. Amphymenium splendiarmatum Clark and Campbell \\ (Plate 11, Figures 6-8; Plate 28, Figures 6-8)}

Amphymenium splendiarmatum Clark and Campbell, 1942, p. 46, pl. 1, figs. 12,14 .

\section{8(6)C. Genus SPONGODISCUS Ehrenberg}

Spongodiscus Ehrenberg, 1854a, p. 237. Type species (designated by Frizzell and Middour, 1951, p. 26) Spongodiscus resurgens Ehrenberg (1854a, p. $246 ; 1854$ b, pl. 35 B, fig. 16 ).

Because the relationships of this and related genera are not understood, we use this generic name in a very broad sense, to include forms with closely spaced concentric rings or no rings in the spongy disc, and with or without radial spines. The rhombic Spongodiscus cruciferus is included here because of its apparently close relationship to a late Paleocene Spongodiscus sp. with very numerous radial spines, though Spongaster klingi Riedel and Sanfilippo (1971) (probably a junior synonym of Spongasteriscus berminghami Campbell and Clark, 1944) is placed in a different genus because it forms part of a well understood Neogene lineage. Amphicraspedum murrayanum evidently arose from a Spongodiscus sp. in the late Paleocene, and because of its distinctive form is left in the genus to which Haeckel assigned it.

\section{8(6)Ca. Spongodiscus americanus Kozlova}

(Plate 11, Figures 9-13; Plate 27, Figure 11; Plate 28, Figure 9)

Spongodiscus americanus Kozlova, in Kozlova and Gorbovets, 1966, p. 88 , pl. 14, figs. $1,2$.

Remarks: This form may be identical with Spongodiscus communis Clark and Campbell (1942, p. 47, pl. 2, figs. 1, 11, 13, 14; pl. 3, figs. 1, 4), but we have avoided using that name because their illustrated specimens may include more than one species. There is considerable similarity also with Spongodiscus biconcavus Haeckel (1887, p. 577; Popofsky, 1912 , p. 143 , pl. 6, fig. 2), but the early Eocene specimens are somewhat larger (up to $370 \mu$ ), sometimes have numerous radial spines on the margin, and have closely spaced dark rings in the thicker central portion.

We have not included in this species a superficially similar form (occurring commonly in 94-27, CC, for example) in which the peripheral meshwork is coarser and the center has a structure similar to that of Spongodiscus pulcher and S. phrix, and which is evidently closely related to those species.

8(6)Cb. Spongodiscus cruciferus Clark and Campbell

(Plate 11, Figures 14-17; Plate 28, Figures 10, 11)

Spongasteriscus cruciferus Clark and Campbell, 1942, p. 50, pl. 1, figs. $1-6,8,10,11,16-18$.

Remarks: Our forms correspond well with Clark and Campbell's description and illustrations, but it seems inappropriate to speak of a "central disc" because there is no such distinct structure, the closely spaced concentric dark rings extending a considerable distance outward along the narrow and broad "arms". Radial spines commonly protrude from the sides and ends of the narrow arms.

This species very closely resembles Spongaster klingi Riedel and Sanfilippo (1971) in general form, and evidently developed from the Late Paleocene Spongodiscus sp. with very numerous radial spines (Plate 11; Figures 18, 19; Plate 29, Figure 1), in the same manner as $S$. klingi 
developed from its discoidal ancestor (probably Spongodiscus biconcavus).

\section{$8(6)$ Cc. Spongodiscus phrix Sanfilippo and Riedel, new species}

Description: Thin discoidal shell with distinctive eyelike center and numerous marginal spines. The central part of the shell appears to consist of a pylonid structure, surrounded by a few dark rings (spiral in some specimens) which become less distinct outward where the structure is irregularly and coarsely spongy. Margin of the disc with a large and variable number of cylindrical radiating spines. Radial spines also protrude obliquely from the shell surfaces, and there are thicker (darker in transmitted light) radii of the disc associated particularly with those spines that protrude from the surface just inward from the periphery. Shell margin somewhat irregular, extending further outward along the stronger radial spines. Prominent marginal pylome commonly present.

Measurements (based on 30 specimens from 94-22-4, 94-25-2, and 94-28-5). Diameter, excluding spines, 225-510 $\mu$.

Remarks: This species is preceded and accompanied by an apparently ancestral form which differs in somewhat smaller diameter (195-250u) and in lacking the thickened radii, and which may be identified as Spongodiscus pulcher Clark and Campbell (1945, p. 26, pl. 4, fig. 5).

The specific name is the Greek phrix (ripple), used as a noun in apposition.

\section{8(6)Cd. Spongodiscus pulcher Clark and Campbell}

(Plate 12, Figures 3-5; Plate 29., Figures 3,4)

Spongodiscus pulcher Clark and Campbell, 1945, p. 26, pl. 4, fig. 5.

Remarks: Although we have not tabulated this species, it is common in many of the Early Eocene samples, where it occurs together with Spongodiscus phrix. In most specimens of $S$. pulcher the disc is of approximately uniform density throughout, but in some the central and peripheral portions are denser than the median zone, giving a superficial resemblance to $S$. biconcavus (which however lacks the distinctive central eyelike structure and has finer spongy meshes).

\section{8(6)Ce. Spongodiscus quartus quartus (Borisenko)}

(Plate 12, Figures 6, 7; Plate 29, Figures 5, 6)

Staurodictya quartus Borisenko, 1958, p. 96, pl. 2, fig. 5 .

Description: Uniformly thin, discoidal shell (in some specimens tending to be angular in outline), with numerous concentric rings and radial bars. Numerous (generally seven to fourteen), evenly spaced concentric rings, and radial rods which extend from the margin to the inner rings, mark off square or rectangular chambers. The first few rings surrounding the central chamber are elliptical. Lattice plate forming each surface of the disc has one to two pores across the breadth of each ring. Radial spines are often present on the margin, and in some specimens, in which these are relatively strong and four to eight in number, they cause the shell outline to be angular.

Measurements (based on 25 specimens from Cores 94-30 and 96-3). Diameter (excluding spines) $160-275 \mu$.

Remarks: This species is distinguished by the very regular square to rectangular internal structure resulting from the evenly spaced rings and radial rods. In contrast to the subspecies $S$. quartus bosoculus, the disc in the nominate subspecies is only one chamber thick throughout.

\section{$8(6) C f$. Spongodiscus quartus bosoculus Sanfilippo and Riedel, new subspecies \\ (Plate 12, Figures 8-10; Plate 29, Figure 7)}

Description: Similar in fundamental structure to the nominate subspecies, but differing in having a larger number (generally 14 to 16 ) of concentric rings, lacking the prominent radial spines which could cause angularity, and in the disc being several chambers thick toward the margin and in the central area. The median area between the thickened margin and central area is thin and delicate, and therefore broken away in many specimens; in some specimens in which it is not broken, delicate rods cross the depression from the central area to the thickened peripheral area.

Measurements (based on 30 specimens from Cores 86-7, 86-8, 94-30, and 96-3). Diameter of disc 165-220 .

The specific name is a combination of the Latin bos (bull) and oculus (eye), and is used as a noun in apposition.
8(6)Cg. Spongodiscus rhabdostylus (Ehrenberg)

(Plate 13, Figures 1-3; Plate 30, Figures 1, 2)

Spongosphaera rhabdostyla Ehrenberg, 1873, p. 256; 1875, pl. 26, figs. 1, 2.

Stylotrochus rhabdostylus (Ehrenberg), Haeckel, 1887, p. 584.

Remarks: The lenticular disc, which is very thick in its middle part, does not show concentric rings. The earliest specimens tend to have four strong, conical radial spines crossed at right angles (rarely two spines), but later assemblages include also specimens with three strong spines. We exclude from this species specimens with more than four strong spines.

\section{8(6)D. Genus STYLOTROCHUS Haeckel}

Stylotrochus Haeckel, 1862, p. 463. Type species uncertain, since that indicated by Campbell, 1954, p. 94, and Strelkov and Lipman, 1959, p. 450 (Stylospongia huxleyi Haeckel, 1862, p. 473, pl. 28, fig. 7) is ineligible because it was not one of the originally included species. Placement of the following species in Stylotrochus is simply a convenience to separate them from the group of species with more closely spaced rings or a simply spongy discoidal skeleton, which we treat under Spongodiscus.

\section{8(6)Da. Stylotrochus alveatus Sanfilippo and Riedel, new species \\ (Plate 13, Figures 4,5; Plate 30, Figures 3,4)}

Description: Strongly biconvex, robust shell with coarsely structured margin. The shell consists essentially of a thin, chambered disc surrounded on all sides by spongy meshwork which is closely connected to the disc peripherally and separated or only loosely connected near the center-thus forming an almost hollow cavity on either side of the disc. Disc concentrically chambered, with dark rings spaced about $10-17 \mathrm{u}$ apart, commonly interrupted by four radial rods; approximately two pores across the breadth of a ring. The surrounding spongy meshwork is rather coarse, especially near the margin, which commonly bears many short, strong spines and in some specimens a few longer cylindrical spines (these latter are often four in number, and collinear with the radial rods of the inner disc).

Measurements (based on 20 specimens from Core 86-8). Diameter, excluding spines, $225-355 \mu$.

Remarks: This species is distinguished from others of the genus by the coarse structure of the margin, and the cavities commonly present on either side of the central disc. In many specimens the loosely supported spongy meshwork is broken away from the faces of the disc, and in others the entire central part is missing. The chambered disc of this species closely resembles $S$. charlestonensis.

The specific name is the Latin alveatus (hollowed out).

\section{$8(6) \mathrm{Db}$. Stylotrochus charlestonensis (Clark and Campbell)? \\ (Plate 13, Figures 6-8; Plate 30, Figures 5,6)}

Porodiscus charlestonensis Clark and Campbell, 1945, p. 23, pl. 3, figs. 11-16.

Remarks: This name is applied, with some hesitation, to a form which occurs throughout our Early to Middle Eocene sequence, and which appears to represent the stock which gave rise to Stylotrochus nitidus and $S$. quadribrachiatus. The principal difficulty in applying this name is that Clark and Campbell describe the rings of the disc as being $10 \mu$ wide, whereas in our specimens the rings average about $14 \mu$ wide. Also, our specimens have only about 2 pores on the breadth of a ring, which agrees with Clark and Campbell's illustrations but not with their written description.

\section{8(6)Dc. Stylotrochus nitidus Sanfilippo and Riedel, new species \\ (Plate 13, Figures 9-14; Plate 30, Figures 7-10)}

Description: Lenticular skeleton, the central part of which shows 4-7 dark, elliptical to circular rings spaced approximately $13-15 \mu$ apart, surrounded by a spongy zone without rings. The thicker, central portion of the lenticular skeleton is covered by spongy meshwork with relatively large pores. Cylindrical spines, commonly about half as long as the shell radius, occur at the shell margin and on its surfaces. Margin between these spines either smooth and entire, or minutely thorny (with entire margin between thorns). Many specimens have a distinct, narrow, marginal pylome. 
Measurements (based on 30 specimens from $94-25-2,94-30-2$, and 96-3-5). Shell diameter (excluding spines) $140-230 \mu$.

Remarks: This species differs from the evidently closely related form that we have recorded as $S$. charlestonensis ? in lacking rings in the peripheral part of the skeleton, and from Stylotrochus geddesii Haeckel (1887, p. 585, pl. 41, fig. 11) in having cylindrical rather than bladed spines.

In the oldest specimens in our material (from $86-7, \mathrm{CC}$ ), the shell has the typical marginal structure but the internal concentric rings are indistinct or lacking.

The specific name is the Latin adjective meaning "neat, elegant".

\section{8(6)Dd. Stylotrochus quadribrachiatus quadribrachiatus Sanfilippo and Riedel, new species \\ (Plate 14, Figures 1, 2; Plate 31, Figure 1)}

Description: Shell consisting of a thin central disc with either four arms approximately at right angles or two opposite arms with lobes of spongy material between them. The central disc contains 3-5 dark, elliptical to circular rings spaced approximately $8-10 \mu$ apart. The arms and lobes generally show internal radial structure continuous with thin cylindrical spines scattered along the surface and especially at the ends of the arms, and in some specimens show vague transverse dark bands as well.

Measurements (based on 30 specimens from Cores 94-25, 94-26, and 94-27). Maximum length (excluding spines) 135-265 $\mu$.

Remarks: Specimens of this form with two arms and two lobes differ from Spongodiscus cruciferus and Amphicraspedum murrayanum in having the rings of the central disc more widely separated. Specimens with four arms do not closely resemble any described species.

\section{8(6)De. Stylotrochus quadribrachiatus multibrachiatus Sanfilippo and Riedel, new subspecies \\ (Plate 14, Figures 3, 4; Plate 31, Figures 2, 3)}

Description: Similar in structure to the nominate subspecies, but with the arms commonly more than four in number (up to 7) and always less regularly formed. Spines are restricted to the margin, and they tend to be quite prominent.

Measurements (based on 25 specimens from Core 94-25). Maximum diameter (excluding spines) 185-255 $\mu$.

Remarks: This form evidently evolved directly from $S$. quadribrachiatus quadribrachiatus.

\section{8(6)E. Genus XIPHOSPIRA Haeckel}

Xiphospira Haeckel, 1887, p. 504. Type species (designated by Campbell, 1954, p. 92) Xiphodictya staurospira Haeckel (1887, p. 504, pl. 42, fig. 12).

We use this generic name for forms in which the concentric, spiral or irregular rings are fewer and more widely spaced than in Spongodiscus, and without any implication regarding the presence or number of radial spines.

\section{8(6)Ea. Xiphospira circularis (Clark and Campbell)}

(Plate 14, Figures 5-12: Plate 31, Figures 4-7)

Porodiscus circularis Clark and Campbell, 1942, p. 42, pl. 2, figs. 2, $6,10$.

Xiphodictya amphixiphos Clark and Campbell, 1942, p. 43, pl. 2, fig. 4 .

Remarks: The concept of this species employed here embraces forms with three to five widely spaced, concentric, spiral or irregular rings (of which the inner ones tend to be elliptical), and with or without radial spines. There are commonly two or three lattice pores in the breadth of a ring. Throughout the late Paleocene to middle Eocene sequence examined, specimens with concentric or spiral rings far outnumber those with irregular rings.

\section{8(7). Family ACANTHODESMIIDAE Haeckel 1862, emend. Riedel 1967}

Goll (1971) has recently attempted to stabilize Trissocyclidae as the name of this family by designating, as lectotype of the type species of Acanthodesmia Müller, an illustration that he believes not to show a sagittal ring. It seems to us, however, that the illustration chosen
(Müller, 1858, pl. 1, fig. 6) is very likely of the same species as at least some of Müller's other figures, and probably has a sagittal ring. We therefore continue to use Acanthodesmiidae as the name of this family, and admit forms (e.g. Rhabdolithis pipa) in which the sagittal ring has apparently degenerated so as to become incomplete. In less formal usage, it is probable that the term "spyroids" or "spyrids" will continue to be used to refer to members of this family (or suborder, as in Petrushevskaya, 1971) until the broad relationships of its members are better understood.

\section{8(7)A. Genus CERATOSPYRIS Ehrenberg}

Ceratospyris Ehrenberg 1847a, chart to p. 385.

Type species (by subsequent monotypy in Ehrenberg, 1847b, p. 43) Haliomma ? radicatum Ehrenberg $(1844$, p. 83$)$.

8(7)Aa. Ceratospyris articulata Ehrenberg

(Plate 15, Figures 1-3; Plate 31, Figures 8,9)

Ceratospyris articulata Ehrenberg, 1873, p. 218; 1875, pl. 20, fig. 4 .

Remarks: This distinctive species is easily recognized by its three or five long robust feet, thicker near their middle part or in the proximal half, circular in section. The apical bar extends freely through the cephalic cavity, and the apical and posterior parts of the sagittal ring are joined to the shell wall. Three feet are associated with the dorsal and primary lateral bars, and when five are present two originate between the dorsal and primary laterals. The shell wall is thick and tubercular, and there is a robust apical horn. Some specimens show fragments of a thin-walled, porous thorax between the feet, and the thorns commonly present on the thickened part of the feet are probably remnants of this structure.

Excluded from this species is a form with shorter, stubby feet, thick and sparsely pored cephalic wall, and stubby apical horns (Plate 15, Figure 4; Plate 31, Figure 10). Height of cephalis $35-50 \mu$; length of feet 55-145 $\mu$ (based on 30 specimens from Cores 94-22, 94-25, 94-28, and 94-30).

\section{8(7)B. Genus DENDROSPYRIS Haeckel}

Dendrospyris Haeckel, 1881, p. 441; emend. Goll, 1968, p. 1417. Type species (indicated by Campbell, 1954, p. 112) Ceratospyris stylophora Ehrenberg (1873, p. 220; 1875, pl. 20, fig. 10).

8(7)Ba. Dendrospyris acuta Goll

(Plate 15, Figure 5; Plate 31, Figure 11)

Dendrospyris acuta Goll, 1968, p. 1419, pl. 173, figs. 7-9, 12.

Remarks: Specimens in our material generally conform with the original description and illustration of this species, with the exception that they rarely have elongate pores at the base of the lattice-shell.

In some samples, this species is accompanied by a less common, apparently closely related form (Plate 15, Figures 6,7; Plate 31, Figure 12) that is larger, more circular in outline, not pointed distally, but with the same separation of the lattice shell from the upper part of the sagittal ring.

\section{8(7)Bb. Dendrospyris fragoides Sanfilippo and Riedel, new species \\ (Plate 15, Figures 8-13; Plate 31, Figures 13,14)}

Description: Shell sparsely pored, dome-shaped, without sagittal constriction, with a series of lamellar teeth distally.

Sagittal ring D-shaped, separated from the lattice shell except for a shorter or greater distance above the vertical spine. Apical bar straight, joined to the lattice-shell by one or two pairs of bars. Apical part of sagittal ring connected with lattice shell by shorter or longer bars, or rarely joined to it directly. Primary and secondary lateral bars, and dorsal bar, well developed. Some specimens have a poorly developed apical spine, and others have a tuft of short thorns apically, but usually the shell surface is completely smooth. Vertical pore distinct.

Lattice shell thick, with sparse, small, circular pores tending to be tubular. Peristome a poreless band, from which arise approximately 15 flat, parallel lamellar teeth.

Measurements (based on 30 specimens from Cores 94-22, 94-25, 94-30, 94-32, and 96-3). Height of shell (including teeth) $70-105 \mu$, of sagittal ring 35-50 $\mu$. Maximum breadth $65-80 \mu$.

Remarks: This species resembles Dendrospyris acuta and D. turriturcica in having the apical part of the sagittal ring separated from the 
lattice shell, but differs from them in possessing a wide peristome with lamellar teeth. The feet are shorter than those of Petalospyris flabellum Ehrenberg (1873, p. $247 ; 1875$, pl. 22, fig. 7 ), though the shape of the cephalis is somewhat similar.

The specific name is derived from the superficial resemblance of the outline to that of a strawberry.

\section{$8(7) B c$. Dendrospyris turriturcica turriturcica Sanfilippo and Riedel, new species}

(Plate 16, Figure 1; Plate 31, Figure 15; Plate 32, Figure 1)

Description: Shell, when viewed anteriorly or posteriorly, showing an elliptical to subangular cephalis without median constriction, and a narrower, open, distally tapering thorax. In side view, the shell is markedly compressed.

The sagittal ring extends somewhat more than half the distance from the collar pores to the apex, and from its top arises an apical spine which is incorporated into the shell wall and then extends as a short thorn from the apical surface. Surface of lattice shell puckered at the level of the top of the sagittal ring. Primary and secondary lateral bars well developed.

Lattice shell robust, with pores of unequal size, subcircular on the cephalis and tending to be longitudinally elongated on the thorax. Vertical pore distinct. Termination of thorax uneven, with irregular lamellar teeth not markedly differentiated from the bars separating adjacent pores.

Measurements (based on 15 specimens from Cores 94-28 and 94-30). Height of shell $80-145 \mu$, of sagittal ring $25-40 \mu$. Maximum breadth $75-120 \mu$

Remarks: This species differs from Dendrospyris acuta in the thorax being open rather than closed, in the pores being more irregular, and in possessing an apical spine. Above its range of occurrence is a somewhat similar form (Plate 16, Figure 2; Plate 32, Figure 2) in which the cephalis is not markedly wider than the thorax-this form is not included in the concept of this species.

\section{8(7)Bd. Dendrospyris turriturcica dasyotus Sanfilippo and Riedel, new subspecies \\ (Plate 16, Figure 3; Plate 32, Figure 3)}

Description: Similar to the nominate subspecies, except that the upper lateral part of each of the two cephalic lobes is somewhat drawn out and perforated by a wide opening surrounded by irregular teeth.

This form evidently developed directly from $D$. turriturcica turriturcica, and cooccurs with it in the upper part of the range of the latter.

The subspecific name is used as a noun in apposition (dasys, tufted; otos, ear).

\section{8(7)C. Genus DICTYOSPYRIS Ehrenberg}

Dictyospyris Ehrenberg, 1847a, chart to p. 385.

It is impossible at this time to define the limits of this genus satisfactorily, because we do not understand the evolutionary lineage sufficiently well. Use of this generic name must therefore depend on an evaluation of the relationship of other species with its type species. Dictyospyris ceratospyris Ehrenberg (1860, p. 823), the type species indicated by Campbell (1954, p. 114), is a nomen nudum, and therefore another type species must be chosen from among the species first described in this genus (by Ehrenberg, 1854). We here designate as the type species Dictyospyris triloba Ehrenberg (1854b, pl. 36, fig. 24; 1873, p. 224 ), which has morphological similarities with the three species treated below, and which occurs in at least Core 94-16 (Section 2, Thyrsocyrtis bromia Zone).

\section{8(7)Ca. Dictyospyris discus Sanfilippo and Riedel, new species \\ (Plate 16, Figures 4-8; Plate 32, Figures 4-7)}

Description: Lattice shell strongly compressed in the apical-basal direction or obliquely in relation to the apical-dorsal bar, and circular to reniform in outline.

Sagittal ring distinct, D-shaped, in reniform specimens joined directly to the shell at apex, base, and posteriorly; the staight anterior bar of the sagittal ring extends freely across the shell cavity, and the indentation of the shell outline corresponds to the posterior part of the ring. In circular specimens, the sagittal ring is of about the same dimensions as in reniform ones, and therefore the posterior part of the sagittal ring (as well as the anterior part) extends freely across the shell cavity. In a small area at the base of the shell (which may be near the center of a flat face of the disc, or near its margin) are three or four collar pores-a pair of cardinal pores and one or two jugular pores posterior to them. The orientation of the sagittal ring in relation to the geometry of the disc varies; in some specimens the apical-dorsal bar is parallel to the axis of the disc and near that axis, while in others it can be at least $45^{\circ}$ from this position so that its apical end is near the center of one face of the disc and its dorsal end near the margin of the opposite face.

Apart from the collar pores in some specimens, and a slightly enlarged vertical pore toward which the vertical spine is directed, the pores of the shell are small and circular. The shell wall is thick and smooth, and the pores therefore tubular. The apical spine is only very rarely expressed externally. Some specimens have thorns irregularly distributed around the margin of the discoidal shell, some have no such thorns, and occasional late reniform specimens have one cylindro-conical spine on the convexly curved margin and two on the indented margin giving a false impression of an apical horn and feet but having no connection with the sagittal ring (Plate 32, Figure 7).

Measurements (based on 30 specimens from 94-32, CC and 96-3, CC). Maximum diameter of lattice shell 85-125 $\mu$, its height (thickness of the disc, measured on only 11 specimens) $40-75 \mu$.

Remarks: This species differs from D. gigas in being more strongly compressed, and in its collar pores being less distinct. It differs from $D$. sphaera in being compressed and in lacking the profusion of branches from the sagittal ring to the inner surface of the lattice shell. In early assemblages, some specimens are elliptical to reniform in outline, and others circular, while in later assemblages (in Core 94-29 and younger) all are elliptical to reniform.

The specific name is the Latin discus, and is used as a noun in apposition.

In the upper part of its range, $D$. discus is accompanied by another species (Plate 32, Figures 8,9; evidently closely related and perhaps even an evolutionary offshoot) in which the collar pores are at the margin of the disc, and the apical-dorsal bar is parallel to the plane of the disc and extended beyond it as a free apical spine. Three strong, usually lanceolate, feet are present-two primary laterals and a dorsal. The vertical pore is situated near the jugular pore(s). The sagittal ring is joined to the discoidal lattice shell posteriorly, is free within the cavity apically, and is connected to the lattice shell by a few bars near the departure of the apical spine from the ring. The proposed close relationship between this form and $D$. discus may seem unlikely in view of the different relationship between the sagittal ring and the geometry of the disc, but it is supported by the fact that in $D$. discus the apical-dorsal bar of the sagittal ring is often oriented obliquely to the axis of the discoidal shell, and there is no other obvious ancestor of this unnamed species. It is important to distinguish this form from superficially similar specimens of $D$. discus having three cylindro-conical marginal spines which bear no fixed relationship to the sagittal ring and its apophyses.

\section{$8(7) \mathrm{Cb}$. Dictyospyris gigas Ehrenberg}

(Plate 16, Figures 9,10; Plate 32, Figures 10,11)

Dictyospyris gigas Ehrenberg, 1873, p. 224; 1875, pl. 19, fig. 6; Bütschli, 1881 , pl. 32 , figs. $14 \mathrm{a}, 14 \mathrm{~b}$.

Remarks: This species was described and illustrated inadequately by Ehrenberg, and more thoroughly by Bütschli. The lattice shell tends to be lobate as a consequence of furrows associated with the posterior part of the sagittal ring and extensions of the secondary lateral bars. The maximum shell diameter is $80-120 \mu$ (based on 30 specimens from Cores 94-28, 94-29, and 94-30), and in seven specimens it was possible to measure the shell height as $50-65 \mu$. In younger assemblages occurs a rather similar form (Plate 32, Figure 12), but without furrows associated with the secondary lateral bars. These forms are therefore less lobate, and we have excluded them from our tabulation of occurrences of $D$. gigas. though they might possibly be included in Bütschli's concept of the species.

\section{8(7)Cc. Dictyospyris melissium Sanfilippo and Riedel, new species}

(Plate 17, Figures 1,2; Plate 32, Figure 13)

Description: Shell discoidal, very variable in size and irregularity of outline, complexly subdivided by internal structures. Externally the shell is formed of a lattice plate with numerous small, circular to subcircular pores. Near the center of one surface of the disc is a larger pore, toward 
which is directed an internal thorn. Interior of shell traversed by numerous, delicate and robust, transverse and oblique (sometimes anastomosing) rods, except for a small central area evident in some specimens as a two-or three-lobed cavity. This cavity and the internal thorn directed toward the larger pore indicate that this form is an acanthodesmiid, but the complexity of the internal structures prevents our being able to determine which bars are parts of the sagittal ring or collar structures.

Measurements (based on 20 specimens from 94-29, CC; $94-30-1$; and 94-30-2). Diameter of disc 125-250 $\mu$. Maximum width of internal cavity $35-60 \mu$.

Remarks: Because it has not been possible to determine the nature of the sagittal ring, nor the phylogenetic development of this species, its assignment to Dictyospyris is very tentative. There is some resemblance to Psychospyris, in the honeycomblike internal structure of the peripheral part of the disc, but $D$. melissium has a much smaller internal cavity than the members of that genus, and its stratigraphic range is clearly prior to the origin of the Psychospyris lineage.

The specific name (melission, honeycomb) is used as a noun in apposition.

8(7)Cd. Dictyospyris sphaera Bütschli

(Plate 17, Figures 3-5; Plate 32, Figures 14-18)

Dictyospyris sphaera Bütschli, 1881, pp. 510-511, pl. 32, figs. 15a, 15 b.

Remarks: The internal structure of shells of this species is difficult to discern because of the profuse branching of the bars connecting the sagittal ring with the lattice shell. The description and figure by Bütschli show all that can be seen without a very thorough investigation, with the following exception. At the base of the shell of well-preserved specimens is a type of small, circular "mouth" surrounding a thin plate joined by three bars to its margin (Plate 32, Figure 17). The collar pores are situated some distance inside this plate, and there is therefore a small cavity that could be regarded as a thorax. The surface of the thick shell wall in some specimens bears numerous spines, and the shell diameter is $85-115 \mu$ (based on 20 specimens from Cores 94-18 and 94-30). In Core 94-24 and younger assemblages, some specimens have pores uniform overall, and it is no longer possible to distinguish specialized pores in the region below the collar pores (Plate 32, Figure 18).

Above the range of this species occurs a superficially similar form with a larger sagittal ring, and lacking the branched bars connecting the sagittal ring with the lattice shell (Plate 32, Figures 19, 20). Cooccurring with the earliest specimens of $D$. sphaera (in Core 94-31, CC) is an apparently related form which is not spherical but compressed in the apical-basal direction.

\section{8(7)D. Genus DORCADOSPYRIS Haeckel}

Dorcadospyris Haeckel, 1881, p. 441.

This generic name is here used to include not only forms in which two feet are especially strongly developed, but also some species assigned to Dorcadospyris by Goll (1969) for other reasons. The result is an uncomfortable association of forms which may not be closely related, but it is not yet possible to make a more satisfactory grouping.

\section{8(7)Da. Dorcadospyris alata (Riedel)}

Brachiospyris alata Riedel, 1959, p. 293, pl. 1, figs. 11, 12.

Dorcadospyris alata (Riedel), Riedel and Sanfilippo, 1970, p. 523, pl. 14, fig. 5 .

\section{8(7)Db. Dorcadospyris ateuchus (Ehrenberg)}

Ceratospyris ateuchus Ehrenberg, 1873, p. 218; 1875, pl. 21, fig. 4. Dorcadospyris ateuchus (Ehrenberg), Riedel and Sanfilippo, 1970, p. 523, pl. 15 , fig. 4 .

\section{8(7)Dc. Dorcadospyris circulus (Haeckel)}

Gamospyris circulus Haeckel, 1887, p. 1042, pl. 83, fig. 19. Dorcadospyris circulus (Haeckel), Moore, 1971.

\section{8(7)Dd. Dorcadospyris confluens (Ehrenberg)}

(Plate 17, Figures 6-10; Plate 33, Figure 1)

Petalospyris confluens Ehrenberg, 1873, p. 246; 1875, pl. 22, fig. 5.

Dorcadospyris confluens (Ehrenberg), Goll, 1969, p. 337, pl. 58, figs. 9-12 (in part, excluding figure).

Remarks: Use of this name is here restricted to specimens with a distinctly porous thorax, and a generally short apical spine. In other respects the species closely resembles $D$. platyacantha, except that the cephalis tends to be wider.

\section{8(7)De. Dorcadospyris dentata Haeckel}

Dorcadospyris dentata Haeckel, 1887, p. 1040, pl. 85, fig. 6; Riedel, 1957 a, p. 79 , pl. 1, fig. 4.

\section{8(7)Df. Dorcadospyris forcipata (Haeckel)}

Dipospyris forcipata Haeckel, 1887, p. 1037, pl. 85, fig. 1. Dorcadospyris forcipata (Haeckel), Riedel and Sanfilippo, 1970, p. 523, pl. 15 , fig. 7.

\section{8(7)Dg. Dorcadospyris papilio (Riedel)}

Hexaspyris papilio Riedel, 1959, p. 294, pl. 2, figs. 1, 2.

Dorcadospyris papilio (Riedel), Riedel and Sanfilippo, 1970, p. 523, pl. 15, fig. 5 .

\section{8(7)Dh. Dorcadospyris platyacantha (Ehrenberg)}

(Plate 17, Figures 11-15; Plate 33, Figure 2)

Petalospyris platyacantha Ehrenberg, 1873, p. 247; 1875, pl. 22, fig. 8. Petalospyris platyacantha Ehrenberg (?), Riedel, 1957b, p. 259, pl. 63, fig. 3.

Dorcadospyris confluens (Ehrenberg), Goll, 1969, p. 337, pl. 58, figs. 9-12 (in part, including figure).

Remarks: This name is here used for forms in which the thorax is very short and poreless, and thus we exclude (and treat as Dorcadospyris confluens) forms with a porous thorax. Goll included both in his concept of $D$. confluens, and the specimen that he figured is one that we treat as D. platyacantha. Among the specimens in our material, many are more elongated laterally than the one figured by Goll, the pores occupy a greater proportion of the shell area, and the horn is longer and more robust.

8(7)Di. Dorcadospyris praeforcipata Moore

Dorcadospyris praeforcipata Moore, 1971.

\section{8(7)Dj. Dorcadospyris pseudopapilio Moore}

Dorcadospyris pseudopapilio Moore, 1971.

8(7)Dk. Dorcadospyris spinosa Moore

Dorcadospyris spinosa Moore, 1971.

\section{8(7)E. Genus GIRAFFOSPYRIS Haeckel}

Giraffospyris Haeckel, 1881, p. 442; emend. Goll, 1969, p. 329. Type species (indicated by Campbell, 1954, p. 114) Ceratospyris heptaceros Ehrenberg (1873, p. 219; 1875, pl. 20, fig. 2).

\section{8(7)Ea. Giraffospyris cyrillium Sanfilippo and Riedel, new species}

(Plate 18, Figures 1-3; Plate 33, Figure 3)

Description: Shell generally rounded, inverted-conical basally. No sagittal constriction, and slight or no constriction between cephalis and thorax.

Sagittal ring D-shaped, connected directly with the lattice shell posteriorly and apically, and separated from it anteriorly. Primary and secondary lateral bars well developed. Apical spine usually protrudes from shell surface as a short thorn.

Lattice shell moderately robust, with subcircular pores, and commonly with few scattered thorns on the surface. Open base of inverted-conical thorax has no differentiated peristome except a less porous area terminated usually by an irregular number of short triangular teeth.

Measurements (based on 20 specimens from 94-28-1; 94-28-5; 94-29, CC; and 94-30-2). Height of shell 75-140 $\mu$, of sagittal ring $30-45 \mu$. Maximum breadth $65-105 \mu$.

Remarks: This species is distinguished from Giraffospyris lata by the rounded rather than pointed lobes of the cephalis, and more robust shell wall.

The specific name is derived from the Greek kyrillion (a jug with a narrow neck), and is used as a noun in apposition. 
$8(7)$ Eb. Giraffospyris lata Goll

(Plate 18, Figures 3-7; Plate 33, Figure 4)

Giraffospyris lata Goll, 1969, p. 334, pl. 58, figs. 22, 24-26.

Remarks: Our specimens conform well with those described and illustrated by Goll. Although the range of the species is short, there is a tendency for the shell to become more triangular in later specimens.

\section{8(7)F. Genus LIRIOSPYRIS Haeckel}

Liriospyris Haeckel, 1881, p. 443; emend. Goll, 1968, p. 1423. Type species (indicated by Campbell, 1954, p. 114) Liriospyris hexapoda Haeckel (1887, p. 1049, pl. 86, fig. 7).

\section{8(7)Fa. Liriospyris parkerae Riedel and Sanfilippo}

Liriospyris parkerae Riedel and Sanfilippo, 1971, p. 1590, pl. 2C, fig. 15; pl. 5, fig. 4.

\section{$8(7) \mathrm{Fb}$. Liriospyris stauropora (Haeckel)}

Trissocyclus stauroporus Haeckel, 1887, p. 987, pl. 83, fig. 5. Liriospyris stauropora (Haeckel), Goll, 1968, p. 1431, pl. 175, figs. 1-3, 7 ; text-fig. 9.

8(7)G. Genus PSYCHOSPYRIS Riedel and Sanfilippo Psychospyris Riedel and Sanfilippo, 1971, p. 1591.

\section{8(7)Ga. Psychospyris grandis Riedel and Sanfilippo}

Psychospyris grandis Riedel and Sanfilippo, 1971, p. 1591, pl. 6, figs. 3-5.

\section{8(7)Gb. Psychospyris intermedia Riedel and Sanfilippo}

Psychospyris intermedia Riedel and Sanfilippo, 1971, p. 1591, pl. 5, fig. 11 ; pl. 6, figs. 1,2 .

\section{8(7)Gc. Psychospyris parva Riedel and Sanfilippo}

Psychospyris parva Riedel and Sanfilippo, 1971, p. 1591, pl. 5, figs. 8-10. $8(7) H$. Genus RHABDOLITHIS Ehrenberg

Rhabdolithis Ehrenberg, 1847b, p. 50-51. Type species (by subsequent designation, here) Rhabdolithis pipa Ehrenberg (1854b, pl. 36, fig. 59).

The discovery of Rhabdolithis ellida elucidates the relationships of the hitherto enigmatic $R$. pipa.

\section{8(7)Ha. Rhabdolithis ellida Sanfilippo and Riedel, new species}

(Plate 18, Figures 8-11; Plate 33, Figures 5-8)

Description: Spinelike skeleton, thickened and sigmoidally curved near one end, and bearing arborescent branches toward the other end. Skeletons usually broken, but rare examples show a short, delicate, median bar from which arise a tiny, thornlike axial spine, a longer, acicular vertical spine, arborescent lateral spines (more commonly primary laterals than secondary laterals), sometimes a dorsal spine, and a strong apical spine that constitutes the most robust part of the skeleton. Apical spine delicate proximally (where the arborescent spines arise), thicker distally, reaching maximal thickness at the sigmoid curve, and cleft terminally to form two short thorns. The sigmoidally curved part of the apical spine is directed "backward" (approximately parallel to the median bar, and in such a position that if extended it might form the upper part of an original sagittal ring).

Measurements (based on 10 specimens from Core 96-3, in which the median bar is preserved). Length from cleft tip of apical spine to median bar $305-440 \mu$.

Remarks: Although the sagittal ring is incomplete, this species seems more appropriately placed in the Acanthodesmiidae than in the Plagoniidae, because the spines arising from the median bar are highly differentiated in a manner similar to those of many acanthodesmiids. Rhabdolithis ellida ranges downward to the earliest Paleocene assemblages presently available, and we therefore have no opportunity to determine its phylogenetic development.
This species is distinguished from $R$. pipa by the lesser degree of thickening and smoother surface of the sigmoid portion of the apical spine, and probably by the more profuse branching of the lateral and accessory spines.

The species is named for the ship of Frithiof, a hero in Icelandic sagas, because of the resemblance of the thickened end of the spine to the prow of a Viking vessel.

$8(7) \mathrm{Hb}$. Rhabdolithis pipa Ehrenberg

(Plate 18, Figures 12-16; Plate 33, Figures 9, 10)

Rhabdolithis pipa Ehrenberg, 1854b, pl. 36, fig. 59; 1875, p. 159, pl. 1, fig. 27.

Remarks: We have not observed any specimens with the median bar preserved, but there is no doubt that this species evolved directly from Rhabdolithis ellida, in which that structure is present. In $R$. pipa the thickened distal part of the apical spine is ellipsoidal to spherical, and its surface roughened with pits, tubercles or ridges. Ehrenberg's description omits mention of accessory spines arising from the proximal half of the apical spine; remnants of such spines are present in many specimens, and they appear not to be so profusely branched as in $R$. ellida. No descendants of $R$. pipa are known, and thus this species may terminate its evolutionary lineage.

\section{8(7)I. Genus TRISTYLOSPYRIS Haeckel}

Tristylospyris Haeckel, 1881, p. 441. Type species (indicated by Campbell (1954, p. 112) Tristylospyris palmipes Haeckel (1887, p. 1033, pl. 84, fig. 14).

\section{8(7)Ia. Tristylospy ris triceros (Ehrenberg)}

Ceratospyris triceros Ehrenberg, 1873, p. 220; 1875, pl. 21, fig. 5. Tristylospyris triceros (Ehrenberg), Haeckel, 1887, p. 1033.

\section{8(8). Family PLAGONIIDAE Haeckel 1881, Emend. Riedel 1967}

Below we treat all of the reasonably common, large members of this family occurring in the early Eocene and late Paleocene samples, but not the small, delicate, two-segmented forms which seem to occur throughout the Cenozoic.

While examing this family, we have also kept notes on the theoperid Dictyophimus craticula Ehrenberg (Plate 19, Figure 1; Plate 33, Figure 11). This species characteristically has the proximal pores on the thorax regularly arranged (with two pores between adjacent feet in the first row, and three pores in the second row), the thorax widely expanded at least proximally, the feet departing from the thorax at the end of the second row of thoracic pores, and the thorax beyond this second row not connected to the feet. In the earliest occurrences (94-28-5 and 94-28, $\mathrm{CC})$, this characteristic form is outnumbered by the apparent ancestor, in which the proximal thoracic pores tend to be not so regularly arranged, the proximal thorax is not so widely expanded, and the thorax tends to be joined to the feet beyond its second row of pores (Plate 19, Figure 2; Plate 33, Figure 12). In at least some of these early specimens, the collar pores are situated lower than in later forms, so that the cephalis is relatively larger.

\section{8(8)A. Genus SPONGOMELISSA Haeckel}

Spongomelissa Haeckel, 1887, p. 1209. Type species (by monotypy) Lithomelissa spongiosa Bütschli (1881, p. 519, pl. 33, figs. 25 a-c).

The following three species are only tentatively included under this generic name, because though they show some similarity to the type species of this genus it is not yet possible to determine whether or not they are closely related to it.

\section{8(8)Aa. Spongomelissa adunca Sanfilippo and Riedel, new species}

(Plate 19, Figures 3,4; Plate 34, Figures 1-6)

Description: Shell flattened-campanulate, with large cephalis, moderately expressed collar stricture, and three downwardly curved feet larger than the robust, bladed apical spine. Cephalis subhemispherical, with either two or three lobes. Furrows connecting the apical spine with the primary laterals are pronounced in all specimens, and some specimens also have a furrow connecting the apical and dorsal spines. From the short median bar arise the apical bar which extends freely in the cephalic cavity and possesses a pair of $a$ branches (in the sense of Petrushevskaya, 1968), the dorsal and primary lateral bars connected with 
strong thoracic ribs terminating in the feet, the vertical spine directed obliquely upward, and a branched axial spine which in some specimens is accompanied by similar structures extending downward from the primary lateral bars. A broad collar velum is connected with the dorsal bar. Most specimens have a latticed tube surrounding the short, protruding vertical spine. This tube is unusual in its large diameter, and in that it is not a prolongation of a single pore, but arises from the surface of the cephalis and thorax, and includes several pores of the shell wall. Wall of cephalis and thorax rough, with subcircular pores, considerably larger in thorax than in cephalis. Peristome of thorax surrounded by a thickened, inturned rim. Feet bladed, in most specimens latticed in the proximal half.

Measurements (based on 30 specimens from 86-8, CC; Core 96-3; and Core 96-4). Width of cephalis $80-135 \mu$, of thorax $125-200 \mu$.

Remarks: Distinguished from Spongomelissa euparyphus as indicated in the description of that species.

The specific name is derived from the Latin adjective aduncus, bent inward.

\section{8(8)Ab. Spongomelissa cucumella Sanfilippo and Riedel, new species \\ (Plate 19, Figures 6,7; Plate 34, Figures 7-10)}

Description: Shell compact, thick-walled, with slightly expressed collar stricture, constricted peristome, and apical spine and three thoracic wings stubby, of approximately the same size and shape. Cephalis large, subhemispherical, in some specimens indistinctly divided into three lobes by furrows corresponding with the $a p$ and probably $m c$ arches of Petrushevskaya (1968). Internal spicular structure comprises a short median bar, apical bar extending freely in the cephalic cavity, vertical bar directed obliquely upward, primary lateral bars, dorsal bar, and short axial spine. The apical and primary lateral bars give off branches just before reaching the shell wall, and the dorsal spine has, in addition, a small amount of lattice work constituting a rudimentary collar velum. Apical spine and three thoracic wings (continuations of dorsal and primary lateral bars) short, thick and bladed. Thorax contracts distally, and terminates in a thick constricted peristome, in many specimens closed by a thin lattice plate. Wall of cephalis and thorax thick, with rounded pores of variable size, similar on the two segments.

Measurements (based on 25 specimens from Core 94-30). Width of cephalis $60-90 \mu$, of thorax $95-125 \mu$.

Remarks: This species is distinguished by its robust horn and wings, thorax constricted distally, and peristome closed by a lattice plate.

The phylogenetic development of this form is not known, but its structure indicates a close relationship to the Spongomelissa adunca-S. euparyphus lineage. Nor does it appear to have left any descendants in cores younger than 94-30, but Core 94-29 contains a somewhat similar though smaller and more delicate form, with no differentiated termination of the thorax (Plate 19, Figure 8; Plate 34, Figure 11). tion.

The specific name (Latin, meaning "kettle") is a noun in apposi-

\section{8(8)Ac. Spongomelissa euparyphus Sanfilippo and \\ Riedel, new species}

(Plate 20, Figure 1; Plate 34, Figures 12, 13)

Description: Similar to Spongomelissa adunca in structure, but differing in the following characters. The general form of the shell is somewhat more flattened, and the feet slightly smaller. There is a more pronounced difference in size between the cephalic and thoracic pores, and the thoracic pores, especially the proximal ones (and also, in some specimens, the cephalic pores), are subdivided into 2-5 smaller pores by delicate bars. Indistinct thoracic ribs collinear with the three feet are present in some specimens. The distal thoracic margin is very characteristic-it is as if the inturned margin of $S$. adunca had become even more compressed, and the outermost edge extended as a flat flange.

Measurements (based on 5 specimens from 94-29, CC and Core 94-30). Width of cephalis $85-110 \mu$, of thorax $185-230 \mu$.

Remarks: There is little doubt that this species is directly descended from Spongomelissa adunca.

The specific name is derived from the Greek adjective euparyphos, with a fine border.

\section{8(8)B. Genus VELICUCULLUS Riedel and Campbell}

Velicucullus Riedel and Campbell, 1952, p. 669. Type species (by monotypy) Soreuma magnificum Clark and Campbell (1942, p. 51, pl. 4, fig. 15).

Under the name Velicucullus spp. (Plate 20, Figures 2-6; Plate 34, Figure 14) we include all forms with a large cephalis, flatly expanded thorax, and no or many feet. The distal margin of the thorax is usually denser in structure than the remainder of the thoracic wall because of the presence of a spongy velum, and the cephalic structure is in general similar to that described for Spongomelissa adunca, though more delicate. In the early forms, at least, there is a well developed collar velum.

\section{8(9). Family CARPOCANNIDAE Haeckel 1881, emend.} Riedel 1967

We have attempted to elucidate the origin of this family, but discontinuities in the available sequence of assemblages has prevented a completely satisfactory solution. Forms (Plate 35, Figures 1,2 ) belonging to Carpocanistrum in the sense of our Leg 7 report (Riedel and Sanfilippo, 1971) extend downward in considerable numbers through Core 95-5 (Theocyrtis tuberosa Zone), and very rarely into Core 94-15 (Thrysocyrtis bromia Zone). The origin of members of this genus is obscure, but one possibility is that they arose from descendants of the pterocoryid Cryptoprora ornate (Plate 35, Figures 3,4) which extend up to Core 94-14 (Thyrocyrtis bromia Zone) but no higher. Associated with $C$. ornata are specimens with a very similar structure but possessing a bladed apical horn (and commonly an opening at the apex of the cephalis), and at least sometimes a pronounced lateral cephalic tubule (Plate 35, Figures 7,8 ). A less likely possibility is that they developed from a theoperid with an ovate thorax, constricted peristome, and commonly three short wings arising from the distal half of the thoracic wall (Plate 35, Figure 6), which range up to Core 94-16 (Thy. roscyrtis bromia Zone).

The distinctive species described below as Carpocanistrum (?) azyx is only questionably assigned generically, because it also may have originated from a member of the Cryptoprora ornata group, but separately and earlier than the forms grouped as Carpocanistrum spp. C. (?) azyx has been found only from Cores 95-6 through 94-15 (Thyrsocyrtis bromia Zone).

\section{8(9)A. Genus CARPOCANISTRUM Haeckel}

Carpocanistrum Haeckel, 1887, p. 1170.

\author{
8(9)Aa. Carpocanistrum (?) azyx Sanfilippo and Riedel, \\ new species \\ (Plate 35, Figure 9)
}

Description: Cephalis within upper part of thoracic wall, and its structure consequently obscure-it is not a small sphere, but a larger structure constructed (at least distally) of widely separated, narrow bars forming a loose "basket". Thorax regularly ellipsoidal, with smooth surface, a somewhat constricted peristome, and thick wall perforated by small, closely spaced, circular pores longitudinally aligned. Peristome narrow, probably with an inwardly directed shelf, terminating in small thorns connected by ridges with the bars between distalmost thoracic pores, and perhaps the remnant of a previously existing abdomen.

Measurements (based on 30 specimens from Cores 94-15, 94-16, and 95-6). Total length 105-140u, maximum breadth $85-120 \mathrm{u}$.

Remarks: This species is distinguished from the forms assigned to Carpocanistrum spp. by its generally larger size, and thick thoracic wall penetrated by numerous, regularly spaced pores.

There is considerable similarity to Carpocanopsis cingulata, but we have refrained from assigning it to that genus because no similar forms connect the latest occurrence of Carpocanistrum (?) azyx with the earliest Carpocanopsis.

The specific name is the Greek azyx (solitary).

8(9)B. Genus CARPOCANOPSIS Riedel and Sanfilippo

Carpocanopsis Riedel and Sanfilippo, 1971, p. 1596.

\section{8(9)Ba. Carpocanopsis bramlettei Riedel and Sanfilippo}

Carpocanopsis bramlettei Riedel and Sanfilippo, 1971, p. 1597, pl. 2G, figs. $8-14$; pl. 8 , fig. 7 . 
8(9)Bb. Carpocanopsis cingulata Riedel and Sanfilippo

Carpocanopsis cingulatum Riedel and Sanfilippo, 1971, p. 1597, pl. 2G, figs. 17-21; pl. 8, fig. 8 .

\section{8(9)Bc. Carpocanopsis cristata (Carnevale)?}

? Sethocorys cristata Carnevale, 1908, p. 31, pl. 4, fig. 18.

Carpocanopsis cristatum (Carnevale)?, Riedel and Sanfilippo, 1971, p. 1597, pl. 1G, fig. 16; pl. 2G, figs. 1-7.

8(9)Bd. Carpocanopsis favosa (Haeckel)

Cycladophora favosa Haeckel, 1887, p. 1380, pl. 62, figs. 5, 6. Carpocanopsis favosum (Haeckel), Riedel and Sanfilippo, 1971, p. 1597, pl. 2G, figs. 15, 16; pl. 8, figs. 9-11.

\section{8(10). Family PTEROCORYIDAE Haeckel 1881, emend. Riedel 1967}

8(10)A. Genus CALOCYCLETTA Haeckel

Calocycletta Haeckel, 1887, p. 1381.

\section{8(10)Aa. Calocycletta costata (Riedel)}

Calocyclas costata Riedel, 1959, p. 296, pl. 2, fig. 9.

Calocycletta costata (Riedel), Riedel and Sanfilippo, 1970, p. 535, pl. 14, fig. 12.

\section{8(10)Ab. Calocycletta virginis Haeckel}

Calocyclas (Calocycletta) virginis Haeckel, 1887, p. 1381, pl. 74, fig. 4. Calocycletta virginis Haeckel, Riedel and Sanfilippo, 1970, p. 535, pl. 14, fig. 10.

\section{8(10)B. Genus PODOCYRTIS Ehrenberg}

Podocyrtis Ehrenberg, 1847a, chart to p. 385.

Subgenus PODOCYRTIS Ehrenberg

Podocyrtis Ehrenberg, Riedel and Sanfilippo, 1970, p. 533.

8(10)Ba. Podocyrtis (podocyrtis) ampla Ehrenberg

Podocyrtis (?) ampla Ehrenberg, 1873, p. 248; 1875, pl. 16, fig. 7.

Podocyrtis (Podocyrtis) ampla Ehrenberg, Riedel and Sanfilippo, 1970 , p. 533 , pl. 12 , figs. 7,8 .

\section{8(10)Bb. Podocyrtis (podocyrtis) diamesa Riedel and Sanfilippo}

(Plate 20, Figures 9,10; Plate 35, Figures 10,11)

Podocyrtis (Podocyrtis) diamesa Riedel and Sanfilippo, 1970, p. 533 (pars), pl. 12, fig. 4 (non figs. 5 and 6).

Remarks: The specific name is now restricted to forms in which the pores of the thorax and abdomen are small, and the mouth, though somewhat constricted, is wider than that of the holotype of Podocyrtis dorus.

\section{8(10)Bc. Podocyrtis (podocyrtis) dorus Sanfilippo and Riedel, new species \\ (Plate 35, Figures 12-14)}

Podocyrtis (Podocyrtis) diamesa Riedel and Sanfilippo, 1970, p. 533 (pars), pl. 12, fig. 5.

Description: Thorax pronouncedly inflated-conical, and lumbar stricture distinct. Pores aligned strictly longitudinally on both thorax and abdomen, those of the abdomen somewhat larger than those of the thorax, separated by longitudinal ridges. Abdomen tapers distally to a mouth at least as narrow as that in the specimen illustrated by Riedel and Sanfilippo (1970, pl. 12, fig. 5). Abdomen in some specimens short, as if compressed, narrowing abruptly rather than tapering distally. The poreless peristome bears a variable number of short triangular teeth, rather than three spathulate feet.

Remarks: This form differs from Podocyrtis diamesa and $P$. phyxis in having the mouth more strongly constricted, and from the latter in having smaller pores.

The specific name is derived from the Greek doros (leather bag), and is used as a noun in apposition.

\section{8(10)Bd. Podocyrtis (podocyrtis) papalis Ehrenberg}

(Plate 20, Figures 11-14; Plate 36, Figures 2,3)

Podocyrtis papalis Ehrenberg, 1847b, fig. 2; 1854b, pl. 36, fig. 23; 1873, p. 251; Riedel and Sanfilippo, 1970, p. 533, pl. 11, fig. 1.

Remarks: This species is the earliest well-understood pterocorythid, and it was therefore hoped that the lower part of the Leg 10 radiolarian sequence would provide clues to the evolutionary origin of its three-lobed cephalis. However, this feature evidently arose during the period between the time of deposition of Core 86-7 and that of Core 96-4, which was not satisfactorily cored. Core 96-5 contains a form somewhat resembling Podocyrtis papalis but lacking feet, and with the cephalis showing indistinct furrows but no bulged lobes (Plate 36, Figure 1).

In the oldest assemblage containing Podocyrtis papalis (from 96-4, $\mathrm{CC})$, radiolarians in two states of preservation are present-some skeletons are very well preserved (and may be from cavings from higher in the hole), and others are so poorly preserved that the cephalic structure of this species cannot be determined. In well preserved specimens from 96-4, CC, and in those from Core 96-3, two lateral cephalic lobes are separated from the unpaired lobe by furrows that extend from near the point of junction of the primary lateral bars with the lattice shell to a point just below that at which the apical spine leaves the cephalic surface, and the entire cephalis is approximately uniformly perforated by pores (Plate 36, Figure 2). The apical bar extends freely within the cephalic cavity. In somewhat younger samples (e.g. Core 94-30), some specimens retain this structure but others have a cephalis in which the lateral furrows join the apical bar (incorporated in the cephalic wall) at a lower point, and the median cephalic lobe is poreless or sparsely pored (Plate 36, Figure 3). In these latter forms, the apical spine tends to have a broad base, with blades originating as the intervening bars between the sparse pores.

\section{8(10)Be. Podocyrtis (podocyrtis) phyxis Sanfilippo and Riedel, new species}

Podocyrtis (Podocyrtis) diamesa Riedel and Sanfilippo, 1970, p. 533 (pars), pl. 12, fig. 6 .

Description: Similar in general form to $P$. diamesa, but rather stocky, with a relatively larger, somewhat more inflated abdomen, and larger pores on both abdomen and thorax. No longitudinal ribs between pores.

Remarks: We here designate the specimen figured by Riedel and Sanfilippo (1970, pl. 12, fig. 6) as the holotype of this species, which is the intermediate form in the evolutionary lineage from Podocyrtis diamesa to $P$. ampla.

The specific name is the Greek phyxis (flight), and is used as a noun in apposition.

\section{8(10)Bf. Podocyrtis (podocyrtis) platypus Sanfilippo and Riedel, new species}

(Plate 21, Figures 1-3; Plate 36, Figures 4,5)

Description: Cephalis elongate-hemispherical, with small pores, bearing a bladed horn somewhat longer than the cephalis. Collar stricture indistinctly marked by change in contour. Thorax inflated-conical, with pores circular or slightly elongate (with inwardly projecting thorns), in longitudinal rows separated by ridges. Generally a slight external lumbar stricture. Abdomen approximately cylindrical, slightly inflated, with pores and intervening ridges in some specimens similar to those of distal part of thorax, in others pores larger and less regularly arranged. Feet long, spathulate, usually heavily ridged, abruptly transversely terminated (or rarely cleft), with abdominal pores in most specimens extending onto the upper part of the feet. No distinct poreless peristome at the abdominal margin between the feet.

Measurements (based on 20 specimens from Cores 94-22, 94-27, and 94-28). Length (excluding horn) $285-370 \mu$, maximum breadth $125-160 \mu$.

Remarks: This species is characterized principally by its distinctively ridged, squared-off feet. It differs from Podocyrtis papalis in having the outline not smoothly fusiform, but tending to show a lumbar stricture, and from $P$. diamesa in the form of the feet and abdominal termination.

The specific name is chosen to indicate that the feet of this form show a general resemblance to the bill of a platypus (Ornithorhynchus anatinus), and is treated as a noun. 


\section{Subgenus LAMPTERIUM Haeckel}

Lampterium Haeckel, 1881, p. 434.

Podocyrtis (Lampterium) Haeckel, Riedel and Sanfilippo, 1970, p. 534.

$8(10) B g$. Podocyrtis (lampterium) amphorma Riedel and Sanfilippo

(Plate 20, Figures 7,8)

Podocyrtis (Lampterium) aphorma Riedel and Sanfilippo, 1970, p. 534, pl. 11, fig. 2.

\section{8(10)Bh. Podocyrtis (lampterium) chalara Riedel} and Sanfilippo

Podocyrtis (Lampterium) chalara Riedel and Sanfilippo, 1970, p. 535, pl. 12 , figs. 2,3 .

8(10)Bi. Podocyrtis (lampterium) goetheana (Haeckel)

Cycladophora goetheana Haeckel, 1887, p. 1376, pl. 65, fig. 5.

Podocyrtis (Lampterium) goetheana (Haeckel), Riedel and Sanfilippo, 1970 , p. 535

8(10)Bj. Podocyrtis (lampterium) mitra Ehrenberg

Podocyrtis mitra Ehrenberg, 1854b, pl. 36, fig. B20.

Podocyrtis (Lampterium) mitra Ehrenberg, Riedel and Sanfilippo, 1970, p. 534 , pl. 11 , figs. 5,6 .

8(10)Bk. Podocyrtis (lampterium) sinuosa Ehrenberg? (Plate 21, Figures 4,5)

[?] Podocyrtis sinuosa Ehrenberg, 1873, p. 253; 1875, pl. 15, fig. 5. Podocyrtis (Lampterium) sinuosa Ehrenberg (?), Riedel and Sanfilippo, 1970, pl. 11, figs. 3,4

8(10)Bl. Podocyrtis (lampterium) trachodes Riedel and Sanfilippo

Podocyrtis (Lampterium) trachodes Riedel and Sanfilippo, 1970, p. 535, pl. 11, fig. 7 ; pl. 12, fig. 1.

\section{$8(10)$ C. Genus THEOCYRTIS Haeckel}

Theocyrtis Haeckel, 1887, p. 1405.

\section{$8(10) \mathrm{Ca}$. Theocyrtis annosa (Riedel)}

Phormocyrtis annosa Riedel, 1959, p. 295, pl. 2, fig. 7.

Theocyrtis annosa (Riedel), Riedel and Sanfilippo, 1970, p. 535, pl. 15, fig. 9 .

\section{$8(10) \mathrm{Cb}$. Theocyrtis tuberosa Riedel}

Theocyrtis tuberosa Riedel, 1959, p. 298, pl. 2, figs. 10, 11.

\section{8(11). Family CANNOBOTRYIDAE Haeckel 1881, emend.} Riedel 1967

The early Eocene samples contain rare cannobotryids, which probably all belong to one species, and which are at least superficially similar to early members of the Botryopyle dictyocephalus group except in that they lack a postcephalic chamber. The antecephalic chamber (in the sense of Petrushevskaya, 1965) is connected to the cephalic chamber by two pairs of large pores separated by the apical bar and its anterior appendages ( $a$ of Petrushevskaya, 1968), and in some specimens also by two or three smaller pores above these large ones. The apical bar extends freely within the upper part of the antecephalic chamber. There is a slight external furrow associated with the ap arch (of Petrushevskaya, 1968), in the wall of the lower anterior part of the cephalic chamber.

These early cannobotryids (Plate 21, Figures 6-13; Plate 36, Figures 6-8) do not have a dorsal branch from the apical bar traversing the antecephalic chamber as in Eribotrys Foreman (1968), but Core 96-3 contains small skeletons resembling the cephalis and upper part of the thorax of pterocorythids, in which such a dorsal branch is present (Plate 36, Figures 8-11). The possible relation of these latter to the late Cretaceous Eribotrys remains to be determined, as also does the reason for the absence of cannobotryids in Cores 96-4, 86-7, and 86-8. The paired lobes of the pterocorythid-like forms may be homologous with the lower part of the antecephalic chamber in the early cannobotryids.

\section{8(11)A. Genus ACROBOTRYS Haeckel}

Acrobotrys Haeckel, 1881, p. 440.

\section{8(11)Aa. Acrobotrys spp.}

Acrobotrys spp., Riedel and Sanfilippo, 1971, p. 1601, pl. 1J, figs. 12-16; pl. 2J, figs. 13-15; pl. 3F, fig. 8 .

\section{8(11)B. Genus BOTRYOCYRTIS Ehrenberg}

Botryocyrtis Ehrenberg, 1860, p. 829. Type species (designated by Campbell, 1954, p. 144) Botryocyrtis caputserpentis Ehrenberg (1872a, p. 301; 1873, pl. 10, fig. 21).

\section{8(11)Ba. Botryocyrtis spp.}

Botryocyrtis spp., Riedel and Sanfilippo, 1971, p. 1602, pl. 1J, figs. 1-11; pl. 2 J, figs. $10-12$; pl. $3 \mathrm{~F}$, fig. 7 .

\section{8(11)C. Genus BOTR YOPYLE Haeckel}

Botryopyle Haeckel, 1881, p. 440. Type species (indicated by Campbell, 1954, p. 144) Botryopyle sethocorys Haeckel (1887, p. 1112, pl. 96, fig. 7).

\section{8(11)Ca. Botryopyle sp. A}

Botryopyle sp. A, Riedel and Sanfilippo, 1971, p. 1602, pl. 2J, figs. 20, 21; pl. 3F, fig. 13.

$8(11) \mathrm{Cb}$. Botryopyle dictyocephalus Haeckel group

Botryopyle dictyocephalus Haeckel, 1887, p. 1113, pl. 96, fig. 6. Botryopyle dictyocephalus Haeckel group, Riedel and Sanfilippo, 1971, p. 1602 , pl. 1J, figs. 21-26; pl. 2J, figs. 16-18; pl. 3F, figs. 9-12.

\section{8(11)D. Genus CENTROBOTRYS Petrushevskaya}

Centrobotrys Petrushevskaya, 1965, p. 113. Type species (by monotypy) Centrobotrys thermophila Petrushevskaya.

\section{8(11)Da. Centrobotrys gravida Moore}

Centrobotrys gravida Moore, 1971.

\section{$8(11) \mathrm{Db}$. Centrobotrys petrushevskayae Sanfilippo and Riedel, new species \\ (Plate 36, Figures 12, 13)}

Centrobotrys (?) sp. A, Riedel and Sanfilippo, 1971, p. 1602, pl. 3F, figs. $15,16$.

Description: Prominent eucephalic lobe surrounded by a large, irregularly pored chamber that is not subdivided into ante- and postcephalic parts. Cephalic outline generally smoothly rounded, but in late forms its apex tends to be pointed though to a lesser degree than in $C$. thermophila. Thorax subcylindrical, its wall irregularly porous, tending to be closed distally in some late specimens.

Measurements (based on 20 specimens from 95-4-4 and 95-5-2) Total length of shell $85-120 \mu$. Maximum breadth of cephalis $45-65 \mu$.

Remarks: This species differs from Centrobotrys thermophila in having a more porous shell and rounded apex, and from $C$. gravida in not having the thorax closed and inflated, and in somewhat thinner shell wall. $C$. petrushevskayae appears to represent an evolutionary link between $C$. gravida and $C$. thermophila.

The species is named for M.G. Petrushevskaya, in recognition of her contributions to the understanding of the fundamental structure of Cannobotryidae and other radiolarian families.

\section{8(11)Dc. Centrobotrys thermophila Petrushevskaya}

Centrobotrys thermophila Petrushevskaya, 1965, p. 115, text-fig. 20.

\section{ACKNOWLEDGMENTS}

Financial support for this study was provided by NSF Grants Nos. GA-11489 and GA-31284X. Many of the slides were prepared by H.P. Foreman while she was aboard Glomar Challenger during Leg 10, and others were prepared by David Clegg at Scripps Institution. The onerous tasks of typing and proofreading were competently performed by M.A. Hanger and M.A. Robertson. 


\section{REFERENCES ${ }^{1}$}

Bailey, J.W., 1856. Notice of microscopic forms found in the soundings of the Sea of Kamtschatka - with a plate. Am. J. Sci., ser. 2. 22, 1.

Borisenko, N.N., 1958. Radiolyarii paleotsena zapadnoi Kubani. Tr. Vses. Neft. Nauchn.-Issled. Inst., Krasnodarskii Filial, no. 17 (Voprosy Geologii, Bureniya i Ekspluatatsii Skvazhin). 81 .

1960a. Novye radiolyarii iz paleotsenovykh otlozhenii Kubani. Tr. Vses. Neft. Nauchn.-Issled. Inst., Krasnodarskii Filial, no. 4 (Geologicheskii Sbornik). 199.

, 1960b. Radiolyarii nizhnego i srednego eotsena zapadnoi Kubani. Tr. Vses. Neft. Nauchn.-Issled. Inst., Krasnodarskii Filial, no. 4 (Geologicheskii Sbornik). 219.

Brandt, R., 1935. In Wetzel, O. Die Mikropaleontologie des Heiligenhafener Kieseltones (Ober-Eozan). Niedersachs. Geol. Ver., Hannover, Jber. 27, 41.

Bury, P. S., 1862. Figures of remarkable forms of Polycystins, or allied organisms, in the Barbados chalk deposit. $11 \mathrm{p}$.

Butschli, O., 1881. Beitrage zur Kenntnis der Radiolarienskelette, insbesondere der der Cyrtida. Z. Wiss. Zool. 36, 485 , pl. 31-33.

Campbell, A.S., 1954. Radiolaria. In Treatise on Invertebrate Paleontology. R.C. Moore (Ed.). (Univ. Kansas Press and Geol. Soc. Am.). Pt. D, Protista 3, 11.

Campbell, A.S. and Clark, B.L., 1944. Miocene radiolarian faunas from Southern California. Geol. Soc. Am., Spec. Paper 51.76 p. 7 pl.

Carnevale, P., 1908. Radiòlarie e silicoflagellati di Bergonzano (Reggio Emilia). R. Ist. Veneto Sci. Lett. Arti, Mem. 28(3),1.

Clark, B.L. and Campbell, A.S., 1942. Eocene radiolarian faunas from the Mt. Diablo area, California. Geol. Soc. Am., Spec. Paper 39. 112 p.

1945. Radiolaria from the Kreyenhagen Formation near Los Banos, California. Geol. Soc. Am., Mem. 10. 66p.

Deflandre, Georges, 1964. Sur le sens du développement, centrifuge ou centripete, des éléments de la coque des Radiolaires Sphaerellaires. C. R. Acad. Sc. Paris. 259, 2117.

Ehrenberg, C. G., 1844. Uber 2 neue Lager von Gebirgsmassen aus Infusorien als Meeres-Absatz in Nord-Amerika und eine Vergleichung derselben mit den organischen Kreide-Gebilden in Europa und Afrika. Kgl. Preuss. Akad. Wiss. Berlin, Ber., Jahre 1844. 57-97.

1847a. Uber eine halibiolithische, von Herrn R. Schomburgk entdeckte, vorherrschend aus mikroskopischen Polycystinen gebildete, Gebirgsmasse von Barbados. Kgl. Preuss. Akad. Wiss. Berlin, Ber., Jahre 1846. 382.

, 1847b. Über die mikroskopischen kieselschaligen Polycystinen als mächtige Gebirgsmasse von Barbados und über das Verhältniss der aus mehr als 300 Neuen Arten bestehenden ganz eigenthümlichen Formengruppe jener Felsmasse zu den jetzt lebenden Thieren und zur Kreidebildung. Eine neue Anregung zur Erforschung des Erdlebens. Kgl. Preuss. Akad. Wiss. Berlin, Ber., Jahre 1847. 40.

\footnotetext{
${ }^{1}$ Note added in proof. Some items of information (complete pagination, plate numbers, etc.) have been deleted from these references by the editorial staff of the Deep Sea Drilling Project. Complete citations of some of the references, including the deleted items, may be found in the radiolarian chapters of Volumes VII and XIV of this series of Initial Reports, and all are contained in the preprint of this chapter distributed to many radiolarian researchers in January, 1972.
}

1854a. Die systematische Characteristik der neuen mikroskopischen Organismen des tiefen Atlantischen Oceans. Kgl. Preuss. Akad. Wiss. Berlin, Ber., Jahre 1854. 236.

1854b. Mikrogeologie. Leipzig (Voss). 374 p. Atlas. 31 p. Fortsetzung (1856). 88 p.

1860. Über den Tiefgrund des stillen Oceans zwischen Californien und den Sandwich-Inseln aus bis $15600^{\prime}$ Tiefe nach Lieut. Brooke, Kgl. Preuss. Akad. Wiss. Berlin, Montasber., Jahre 1860. 819.

1872a. Mikrogeologischen Studien als Zusammenfassung der Beobachtungen des kleinsten Lebens der Meeres Tiefgründe aller Zonen und dessen geologischen Einfluss. Kgl. Preuss. Akad. Wiss. Berlin, Monatsber., Jahre 1872. 265.

1872b. Mikrogeologische Studien über das kleinste Leben der Meeres-Tiefgründe aller Zonen und dessen geologischen Einfluss. Kgl. Akad. Wiss. Berlin, Abh., Jahre 1872. 131.

1873. Grössere Felsproben des Polycystinen-Mergels von Barbados mit weiteren Erläuterungen. Kgl. Preuss. Akad. Wiss. Berlin, Ber., Jahre 1873. 213.

1875. Fortsetzung der mikrogeologischen Studien als Gesammt-Uebersicht der mikroskopischen Paläontologie gleichartig analysirter Gebirgsarten der Erde, mit specieller Rücksicht auf den Polycystinen-Mergel von Barbados. Kgl. Akad. Wiss. Berlin, Abh., Jahre 1875. 1.

Foreman, H.P., 1968. Upper Maestrichtian Radiolaria of California. Spec. Pap. Palaeontol. (Palaeontol. Assoc., London), no. 3.82 p., 8 pl.

Friend, J.K. and Riedel, W.R., 1967. Cenozoic orosphaerid radiolarians from tropical Pacific sediments. Micropaleontology. 13, 217.

Frizzell, D.L. and Middour, E.S., 1951. Paleocene Radiolaria from southeastern Missouri. Univ. Missouri, Sch. Mines Met., Bull., tech. ser., no. 77. 1.

Goll, R.M., 1968. Classification and phylogeny of Cenozoic Trissocyclidae (Radiolaria) in the Pacific and Caribbean Basins. Part I. J. Paleontol. 42 (6), 1409.

1969. Classification and phylogeny of Cenozoic Trissocyclidae (Radiolaria) in the Pacific and Caribbean Basins. Part II. J. Paleontol. 43 (2), 322.

1971. Nomenclatural controversy concerning an emended family of Radiolaria. J. Paleontol. 45 (4), 734.

Haeckel, Ernst, 1860a. Über neue, lebende Radiolarien des Mittelmeeres. Kgl. Preuss. Akad. Wiss. Berlin, Monatsber., Jahre 1860. 794.

1860b. Abbildungen und Diagnosen neuer Gattungen und Arten von lebenden Radiolarien des Mittelmeeres. Kgl. Preuss. Akad. Wiss. Berlin, Monatsber., Jahre 1860. 835.

1862. Die Radiolarien. (Rhizopoda Radiaria). Berlin (Reimer). 572 p.; Atlas.

1881. Entwurf eines Radiolarien-Systems auf Grund von Studien der Challenger-Radiolarien. Jena. Z. Med. Naturwiss. 15 (new ser., 8) (3), 418.

1887. Report on the Radiolaria collected by H.M.S. Challenger during the years 1873-76. Rep. Voyage Challenger, Zool. vol. 18. 1803 p.

Harting, P., 1863. Bijdrage tot de kennis der mikroskopische faune en flora van de Banda-Zee. Kon. Akad. Wetensch. Amsterdam, Verh. 10, 1.

Hinde, G.J., 1890. Notes on Radiolaria from the Lower Palaeozoic rocks (Llandeilo-Caradoc) of the South of Scotland. Ann. Mag. Natur. Hist., ser. 6.6 (31), 40.

Hollande, André and Enjumet, Monique, 1960. Cytologie, évolution et systematique des Sphaeroïdés (Radiolaires). Arch. Mus. Natn. Hist. Nat., Paris, ser. 7. 7, 1. 
Kozlova, G.E., 1967a. Tipy stroeniya skeletov radiolyarii iz semeistva Porodiscidae. Zool. Zh. 46 (8), 1163. 1967b. O filogeneticheskoi svyazi podotryadov Discoidea i Larcoidea (Radiolaria, Spumellaria). Zool. Zh. $46(9), 1311$.

Kozlova, G.E. and Gorbovets, A.N., 1966. Radiolyarii verkhnemelovykh i verkhneeotsenovykh otlozhenii ZapadnoSibirskoi Nizmennosti. Tr. Vses. Neft. Nauch.-Issled. Geologorazved. Inst. (VNIGRI), no. 248. 159 p.

Krasheninnikov, V.A., 1960. Nekotorye Radiolyarii Nizhnego i Srednego Eotsena Zapadnogo Predkavkazya. Min. Geol. i Okhr. Nedr SSSR, Vses. Nauch. Issled. Geol. Neft. Inst., no. 16. 271.

Lipman, R. Kh., 1950. Radiolyarii eotsena Kyzyl-Kumov. Min. Geol. SSSR., Tr. Vses. Nauch.-Issled. Geol. Inst. (VSEGEI), 1950. 51 .

1960. Radiolaria. In Stratigrafiya i fauna paleogenovykh otlozhenii zapadno-sibirskoi nizmennosti. Min. Geol. SSSR, Tr. Vses. Nauch.-Issled. Geol. Inst. (VSEGEI), new ser. 28, 69.

Loeblich, A.R., Jr. and Tappan, Helen, 1961. Remarks on the systematics of the Sarkodina (Protozoa), renamed homonyms and new and validated genera. Biol. Soc. Washington, Proc. 74, 213.

Mamedov, N.A., 1969. Novye predstaviteli eotsenovykh radiolyarii Azerbaidzhana. In Iskopaemye i Sovremennye Radiolyarii : Materialy vtorogo vsesoyuznogo seminara po radiolariyam (izdatelstvo Lvovskogo Universiteta). 94.

Mast, Heinrich, 1910. Die Astrosphaeriden. Wiss. Ergebn. Deut. Tiefsee-Exped. "Valdivia", vol. 19, pt. 4, 123.

Moore, T.C., Jr., 1971. Radiolaria. In Tracey, J.I., Jr., Sutton, G.H. et al., 1971. Initial Reports of the Deep Sea Drilling Project, Volume VIII. Washington (U.S. Government Printing Office). 727.

Müller, Johannes, 1858. Über die Thalassicollen, Polycystinen und Acanthometren des Mittelmeeres. Kgl. Akad. Wiss. Berlin, Abh., Jahre 1858. 1.

Perner, J., 1891. O radiolariích z ceského ùtvaru krídového. Sber. k. böhm. Ges. Wiss., 1891. 255.

Petrushevskaya, M.G., 1965. Osobennosti konstruktsii skeleta radiolyarii Botryoidae (otr. Nassellaria). Tr. Zool. Inst. Leningrad. 35, 79 .

1968. Gomologii v skeletakh radiolyarii Nassellaria.

2. Osnovnye skeletnye dugi slozhnoustroennykh tsefalisov Cyrtoidae i Botryoidae. Zool. Zh. 47 (12), 1766.

1971. On the natural system of polycystine Radiolaria (Class Sarcodina). Proc. Second Planktonic Conference. 2, 981.

Popofsky, A., 1912. Die Sphaerellarien des Warmwassergebietes. Deut. Südpol.-Exped. 1901-1903. 13 (Zool. 5). (2), 73.

Riedel, W.R., 1957a. Radiolaria: a preliminary stratigraphy. Rep. Swed. Deep-Sea Exped. 6 (3), 59.

1957b. Eocene Radiolaria. U.S. Geol. Surv., Prof. Paper 280G. 257.

1959. Oligocene and Lower Miocene Radiolaria in tropical Pacific sediments. Micropaleontology. 5 (3), 285. 1967. Subclass Radiolaria. In The Fossil Record. W.B. Harland et al. (Eds.). London (Geol. Soc. London). 291.

1971. Systematic classification of polycystine Radiolaria. In The Micropalaeontology of Oceans. B.M. Funnell and W.R. Riede! (Eds.). Cambridge (Cambridge Univ. Press). 649

Riedel, W.R. and Campbell, A.S., 1952. A new Eocene radiolarian genus. J. Paleontol. 26 (4), 667

Riedel, W.R. and Sanfilippo, Annika, 1970. Radiolaria, Leg 4, Deep Sea Drilling Project. In Bader, R.G., Gerard, R.D. et al., 1970. Initial Reports of the Deep Sea Drilling Project, Volume IV. Washington (U.S. Government Printing Office). 503.

1971. Cenozoic Radiolaria from the western tropical Pacific, Leg 7. In Winterer, E.L., Riedel, W.R. et al., 1971. Initial Reports of the Deep Sea Drilling Project, Volume VII, Pt. 2. Washington (U.S. Government Printing Office). 1529.

Rüst, David, 1885. Beiträge zur Kenntniss der fossilen Radiolarien aus Gesteinen des Jura. Palaeontographica. 31, ser. 3 (7), 273.

Shrubsole, W.H., 1889. Notes on the Radiolaria of the London Clay. Geol. Soc. London, Quart. Jour. 45, 121.

Strelkov, A.A. and Lipman, R. Kh., 1959. Podklass Radiolaria. Sistematicheskaya Chast. In Osnovy Paleontologii. Yu. A. Orlov (Ed.). Moscow (izdatelstvo Akad. Nauk SSSR). Obshchaya chast, Prosteishie. 426.

Sutton, H.J., 1896. Radiolaria; a new genus from Barbados. Am. Mon. Microsc. J. 17 (194), 61.

\section{PLATES}

Plates 1-21 constitute a synchronopticon, with figures arranged in such a way that a horizontal row contains the forms in an assemblage of one age, and vertical rows show changes in a group through time. The youngest assemblage is at the top of these plates, and the oldest at the bottom. The five samples from which the illustrated specimens were obtained are the following: 94-22-4 (42-44 cm), 94-28-5 (43-45 cm), 94-30-2 (114-116 cm), 96-3-5 (42-44 $\mathrm{cm})$, and $86-8(\mathrm{CC})$. These are the same levels as used by Foreman in the synchronopticon in her chapter in this volume. Because each horizontal row generally illustrates forms from a single sample, it has not been necessary to specify the sample in the explanation of each figure. However, in those cases in which a species does not occur in the samples used for the synchronopticon, or in which it has not been possible to find a suitable specimen in one of the above five samples, a specimen has been chosen from another sample and its source is specified in the figure explanation.

The sample number and slide designations indicate preparations in our collection at Scripps Institution of Oceanography, and designations in the form " $U$ 35/1" indicate England Finder positions of the illustrated specimens on the slides. Slides bearing type specimens will be deposited in the U.S. Museum of Natural History, Washington, D.C.

Evolutionary limits have been applied, where possible, in naming the species in the explanations to the synchronopticon plates. The abundance of each morphotype in an assemblage is indicated by "a" (abundant), "c" (common), "f" (few), "r" (rare), or " +" (very rare) near the top of each figure.

We attempted to use only a few different magnifications in preparing the illustrations, but breakdown of one set of photomicrographic equipment during the course of this work forced us to change to another, resulting in a larger variety of magnifications than is desirable. The reader is therefore cautioned to note the magnifications given, when comparing illustrations. 



\section{PLATE 1}

Figures 1-5 Amphisphaera minor (Clark and Campbell)

1. Cse. $1, \mathrm{X} 29 / 4(95 \times)$

2. Cse. $1, \mathrm{~F} 22 / 0(95 \times)$

3. Cse. $1, \mathrm{D} 30 / 3(95 \times)$

4. Cse. G, D23/3 $(95 \times)$

5. Cse. A, D19/1 $(95 \times)$

Figures 6-12 Axoprunum pierinae (Clark and Campbell) group

6. Cse. 1, L22/0 $(95 \times)$

7. Sl. $1, \mathrm{~L} 5 / 4(95 \times)$

8. Cse. $1, Q 35 / 0(95 \times)$

9. Cse. $1, \mathrm{R} 36 / 0(95 \times)$

10. Cse. G, L16/1 $(95 \times)$

11. Cse. G, M22/2 $(95 \times)$

12. Cse. $1, \mathrm{~T} 39 / 4(95 \times)$

Figures 13-17 Stylosphaera coronata coronata Ehrenberg

13. $\mathrm{Ph} .2$, Y $21 / 1(95 \times)$

14. S1. $1,040 / 0(95 \times)$

15. Cse. $1, \mathrm{R} 36 / 0(95 \times)$

16. Sl. A, X23/0 (95X)

17. Sl. A, W9/3 $(95 \times)$

Figure 18 Stylosphaera coronata sabaca Sanfilippo and Riedel, n. subsp.

Cse. $1, \mathrm{~N} 22 / 0(95 \times)$

Figure 19 Stylosphaera coronata laevis Ehrenberg Ph. 2, Y42/2 $(95 \times)$

Figures 20-22 Stylosphaera goruna Sanfilippo and Riedel, n. sp. 20. Sl. A, T34/0 $(95 \times)$

21. Sl. A, K8/1 (165X)

22. Sl. A, E35/3 $(165 \times)$ 

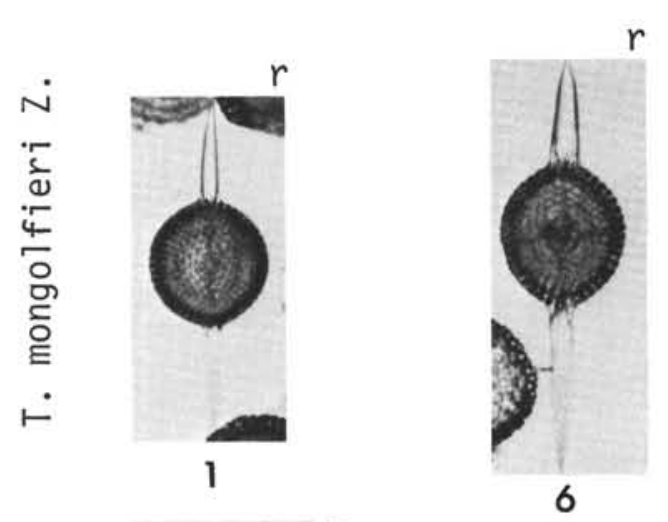

PLATE 1
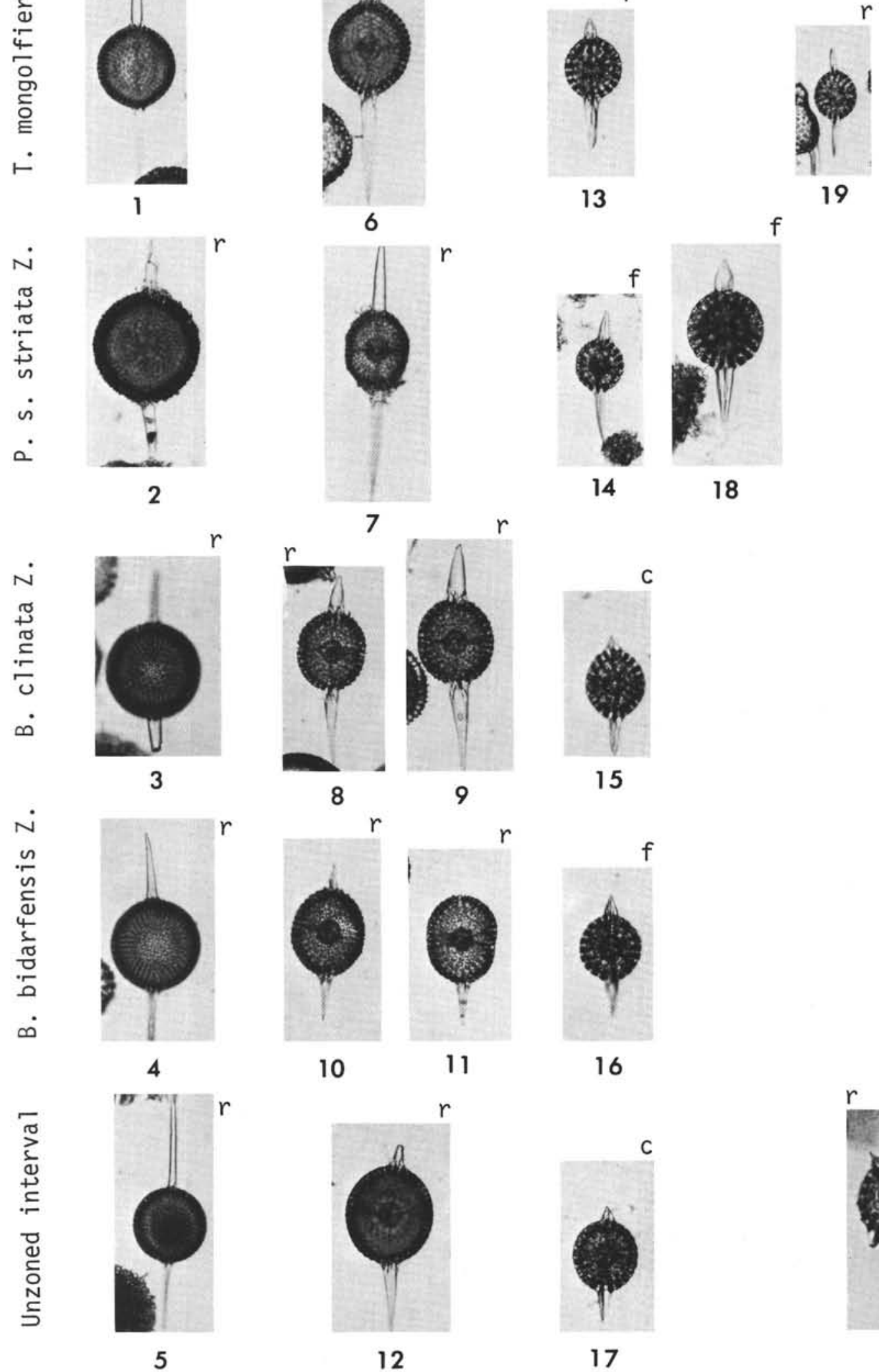
PLATE 2

Figures 1-3 Spongatractus balbis Sanfilippo and Riedel, n. sp.

1. Cse. $1, \mathrm{D} 44 / 3(95 \times)$

2. Cse. 5, K20/4 $(95 \times)$

3. Cse. $1, \mathrm{Q} 48 / 2(95 \times)$

Figures 4-6 Spongatractus pachystylus (Ehrenberg)

4. Cse. $1, X 24 / 4(95 \times)$

5. Cse. $5, \mathrm{~N} 23 / 3(95 \times)$

6. Sl. $1, \mathrm{~J} 12 / 0(95 \times)$

Figures 7-9 Theocosphaerella Sp. cf. T. agdaraensis (Mamedov)

7. Cse. $1, \mathrm{~L} 16 / 3(95 \times)$

8. Sl. $1, \mathrm{~L} 34 / 2(95 \times)$

9. Sl. $1, \mathrm{Y} 46 / 1(95 \times)$

Figures 10-19 Entapium regulare Sanfilippo and Riedel, n. sp.

10. Cse. $1, \mathrm{R} 45 / 1(95 \times)$

11. Cse. $1, \mathrm{~T} 19 / 4(95 \times)$

12. Cse. $1, \mathrm{~T} 39 / 1(95 \times)$

13. Cse. $1, Q 35 / 4(95 \times)$

14. Cse. 1, Q24/3 $(95 \times)$

15. Cse. $1, \mathrm{~T} 43 / 3(95 \times)$

16. Cse. $2, \mathrm{H} 47 / 2(105 \times)$

17. Cse. G, L22/0 (105 $\times)$

18. Cse., M19/0 (95X)

19. Cse. $1, \mathrm{~V} 10 / 4(95 \times)$ 


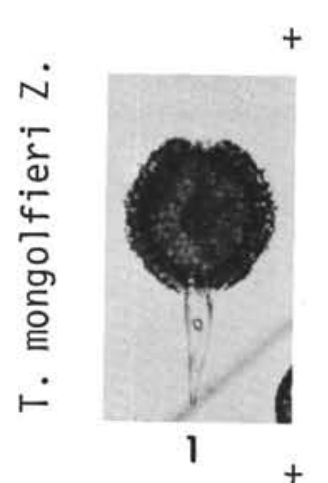

\section{PLATE 2}
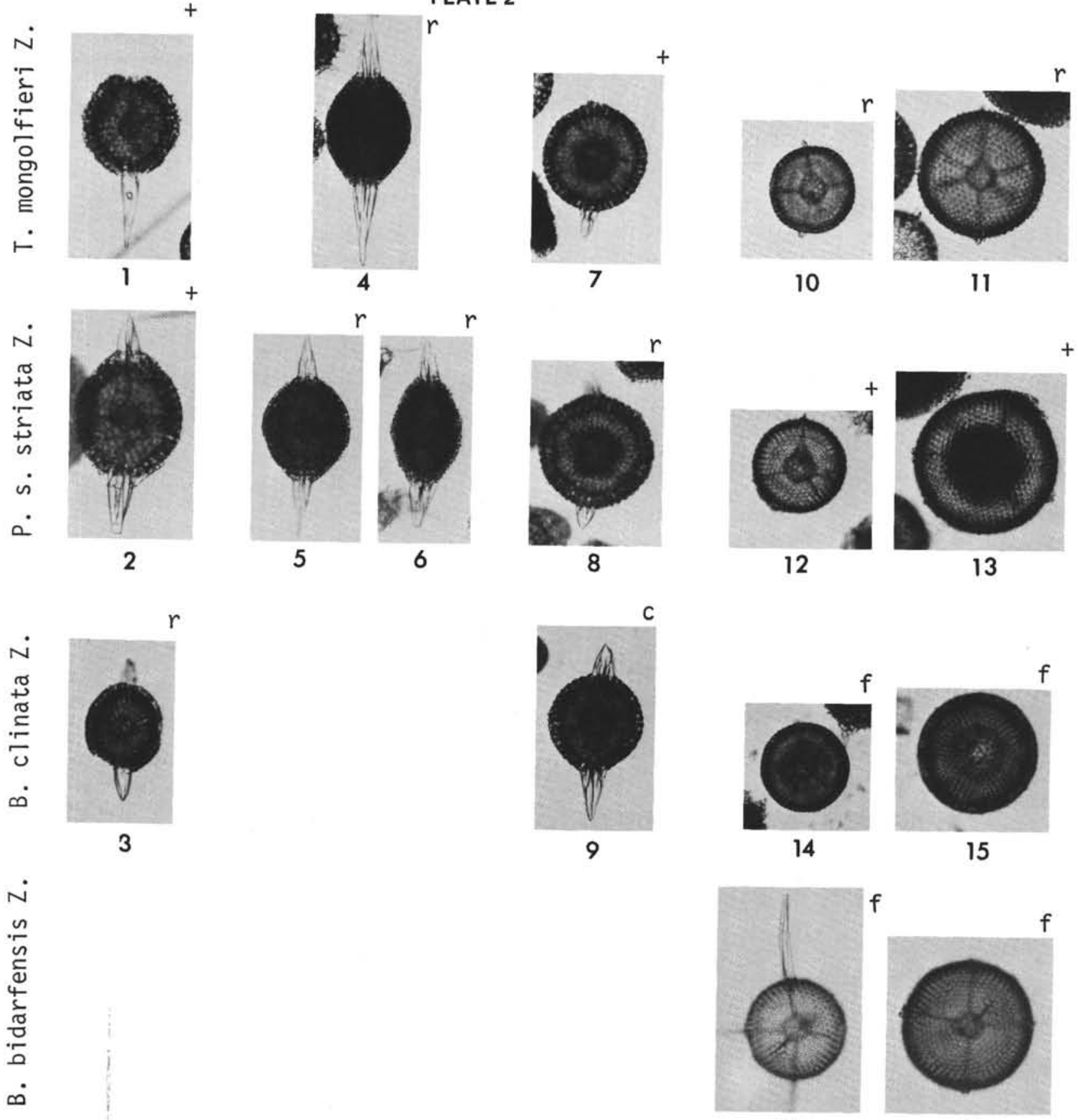

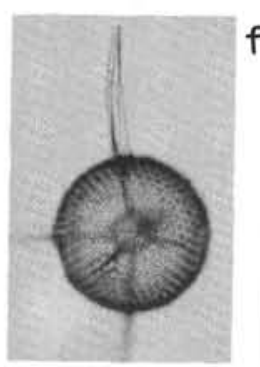

16

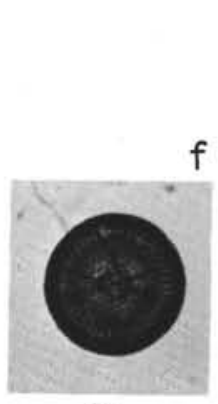

18

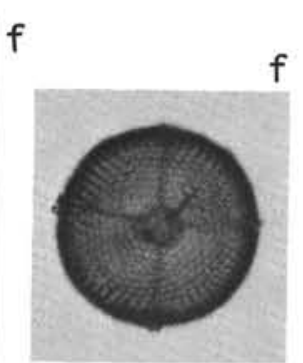

17

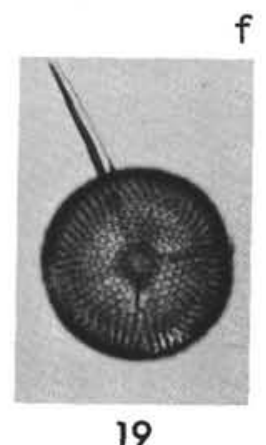




\section{PLATE 3}

Figures 1, 2 Lithapium plegmacantha Riedel and Sanfilippo

1. Cse. 1, U12/2 (95X)

2. S1. $2, \mathrm{U} 30 / 4(95 \mathrm{X})$

Figure 3 Entapium chaenapium Sanfilippo and Riedel, n. sp. Cse. 5, M27/3 (95 $\times)$

Figures 4-6 Thecosphaera larnacium Sanfilippo and Riedel, n. sp.

4. Cse. $1, \mathrm{~B} 18 / 1(95 \times)$

5. Cse. G, L26/1 $(95 \times)$

6. Cse., V34/0 $(95 \times)$

Figures 7-11 Thecosphaerella rotunda (Borisenko)

7. Cse. $1, \mathrm{U} 37 / 4(95 \times)$

8. Sl. $1, \mathrm{~V} 25 / 3(95 \times)$

9. Sl. $1, \mathrm{X} 50 / 3(95 \times)$

10. Cse. E, K46/4 $(95 \times)$

11. Cse. $1, \mathrm{~L} 14 / 1(95 \times)$

Figures 12, 13 Thecosphaerella glebulenta Sanfilippo and Riedel, $\mathrm{n}$. sp.

12. Cse. $1, \mathrm{~W} 14 / 1(95 \times)$

13. Cse. $1, \mathrm{Y} 15 / 4(95 \times)$

Figures 14-18 Thecosphaerella ptomatus Sanfilippo and Riedel, $\mathrm{n}$. sp.

14. Cse. $1, \mathrm{P} 39 / 3(95 \times)$

15. Cse. $1, \mathrm{~L} 14 / 0(95 \times)$

16. Cse. 1, Q19/0 $(95 \times)$

17. Cse. G, W8/3 $(105 \times)$

18. Cse. $1, \mathrm{~W} 28 / 0(95 \times)$ 
PLATE 3
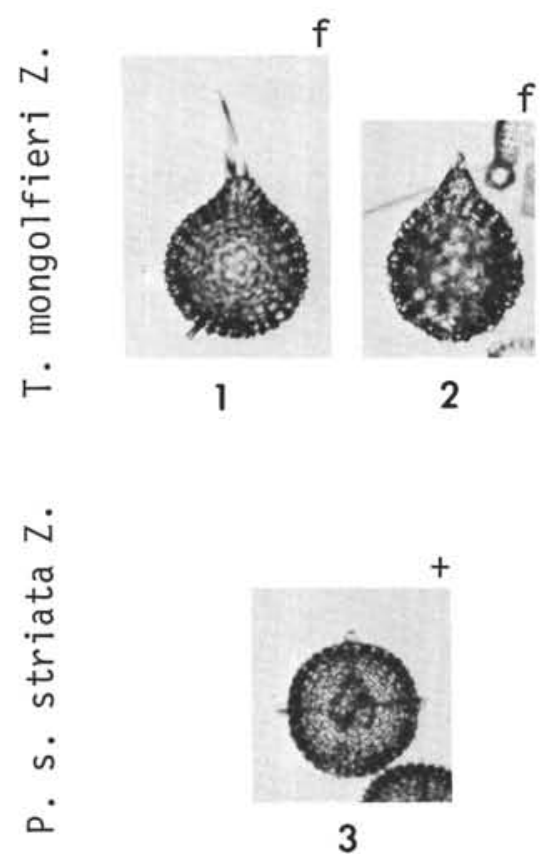

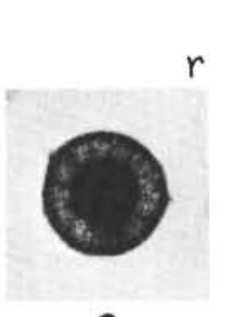

8

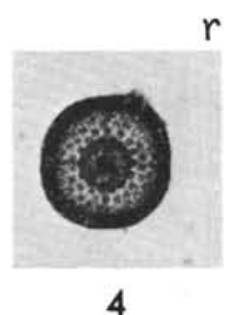

4

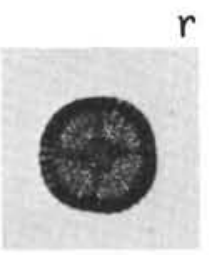

5
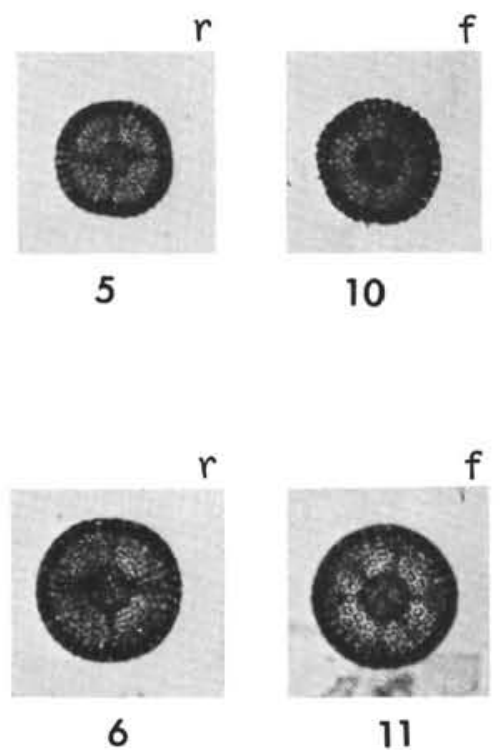
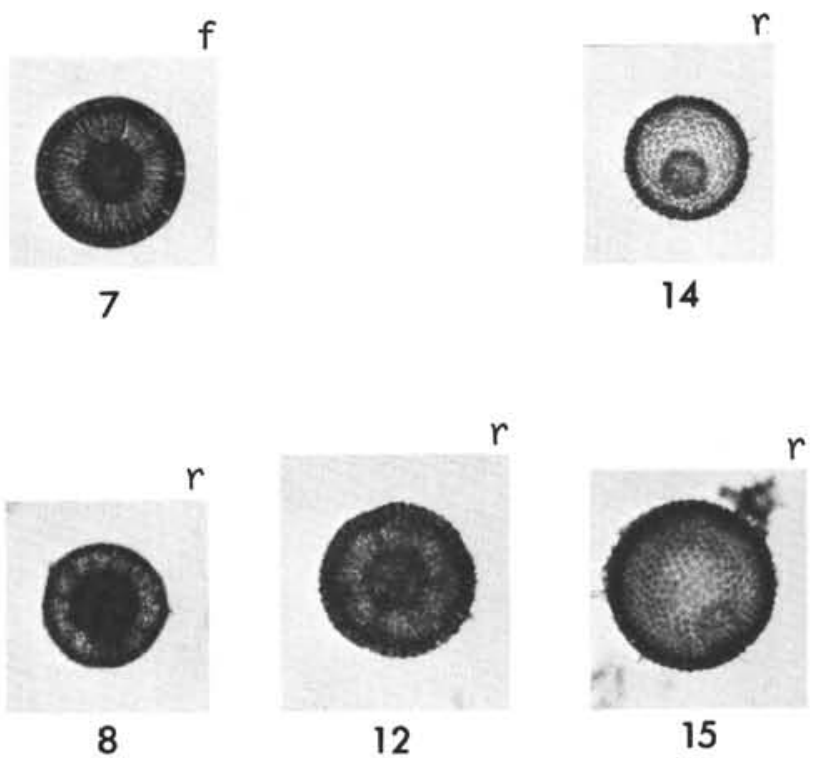

12

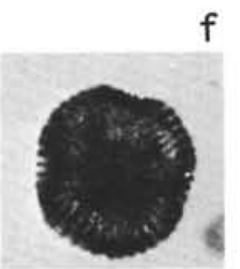

13

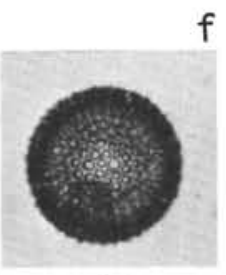

16

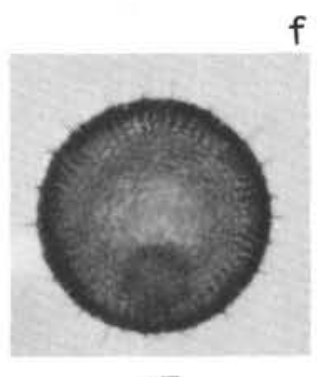

17

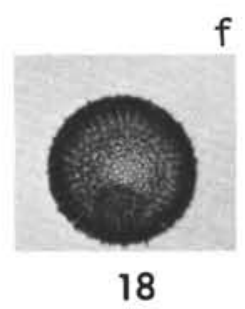




\section{PLATE 4}

Figure $1 \quad$ Hexalonche (?) sp. A

Cse., Q38/2 (95×)

Figure 2 Hexacontium palaeocenicum Sanfilippo and Riedel, n. sp.

Cse. $1, \mathrm{~N} 30 / 0(95 \times)$

Figure 3 Carposphaera subbotinae (Borisenko)

Cse. $1, \mathrm{~N} 30 / 0(95 \times)$

Figure $4 \quad$ Cenosphaera sp. A

Sl. $1, \mathrm{X} 26 / 2(95 \times)$

Figure 5 Diploplegma somphum Sanfilippo and Riedel, n. sp.

Cse., J37/0 (95X)

Figures 6, 7 Lithomespilus mendosa (Krasheninnikov)

6. Cse. 1, E29/2 (95X)

7 Cse. $1, \mathrm{~J} 9 / 4(95 \times)$ 
PLATE 4

N

혼

$\vdash$

Ni

तु

$\frac{\pi}{2}$

is

๑

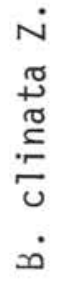

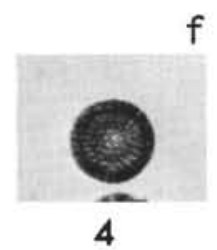

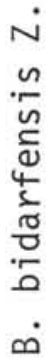

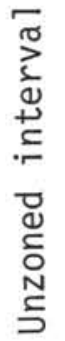
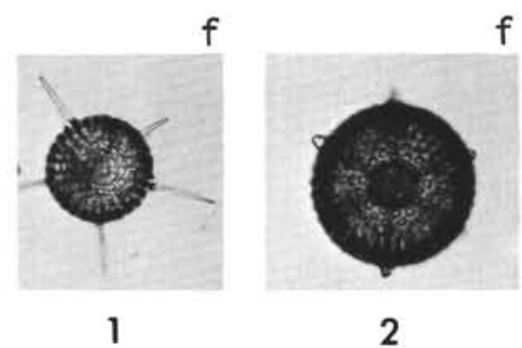

f

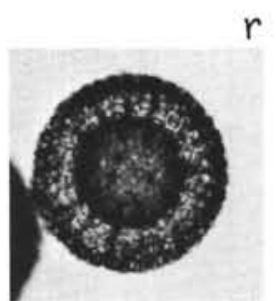

3

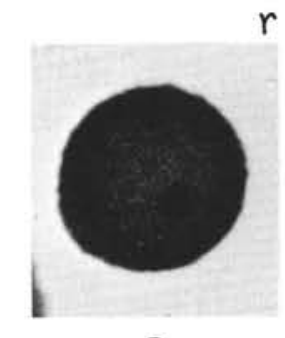

5

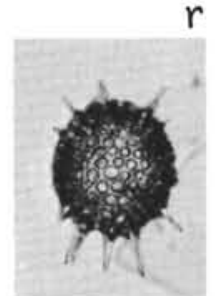

6

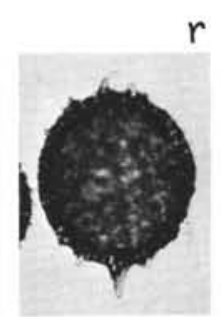

7 
PLATE 5

Figures 1, 2 Astrosphaerin sp. A

1. Cse., V38/0 $(95 \times)$

2. Cse., $X 7 / 2(95 \times)$

Figures 3, $4 \quad$ Astrosphaerin sp. B

3. Cse. $1, \mathrm{Y} 42 / 1(95 \times)$

4. Cse. F, S23/0 $(95 \times)$

Figures 5, 6 Astrosphaerin sp.C

5. Cse. F, Q10/2 $(95 \times)$

6. Cse. F, H31/1 $(95 \times)$ 
Plate 5

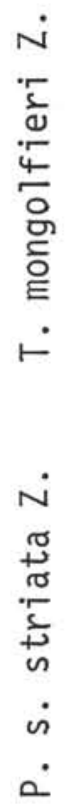

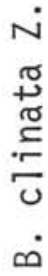
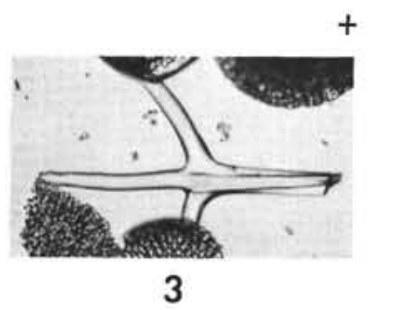

Ni

的

$\frac{1}{0}$
$\frac{1}{4}$
4
$\frac{1}{0}$
$\frac{\pi}{0}$
$\frac{0}{0}$

$r$
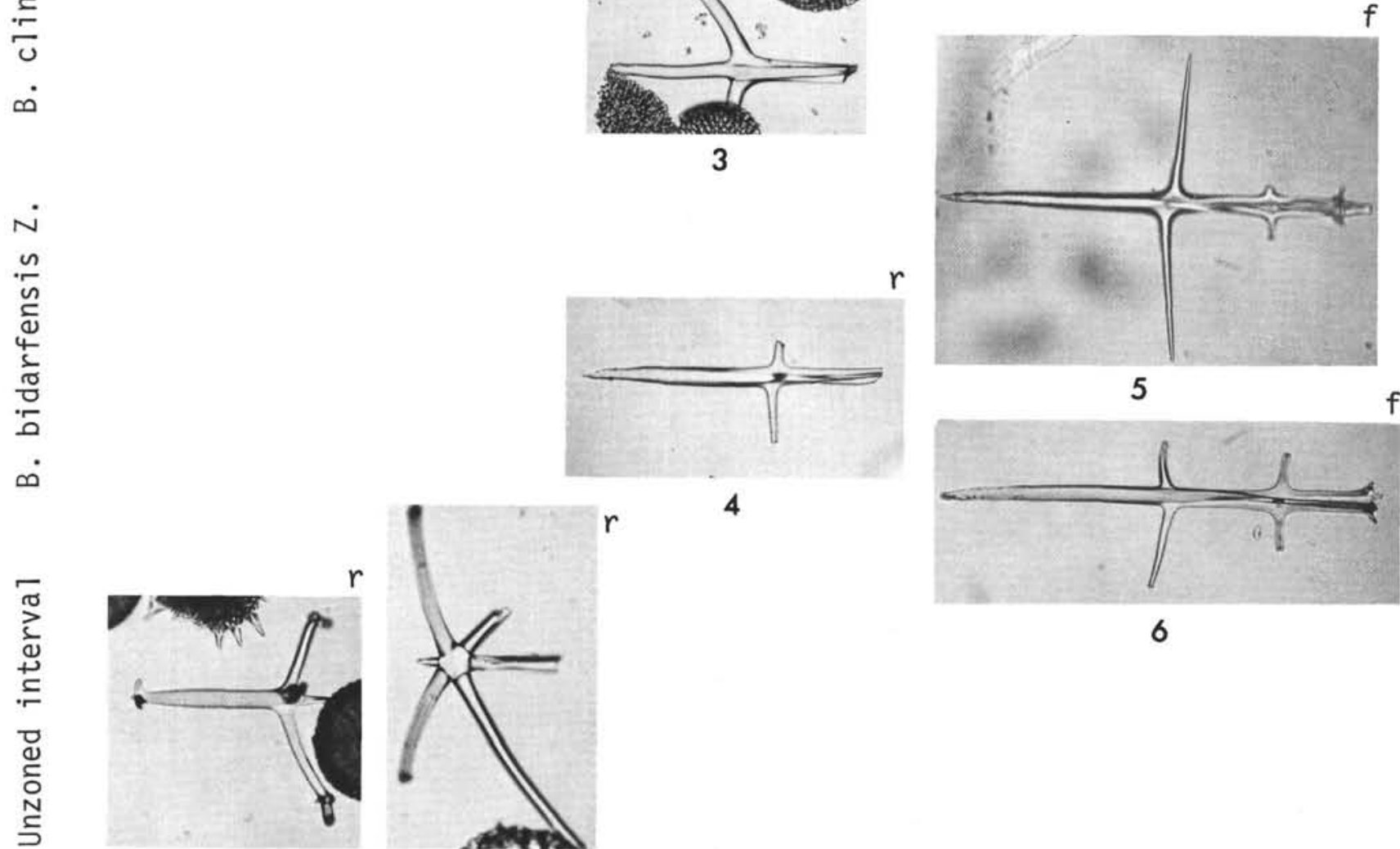

1

4

6 


\section{PLATE 6}

Figures 1, 2 Astrosphaerin sp. D

1. 96-3-6 (42-44 cm). Cse. 1, W17/2 (95X)

2. Cse., U20/4 (95X)

Figures 3-6 Astrosphaerin sp. E

3. Cse. 1, V27/1 $(95 \times)$

4. $96-3-6(42-44 \mathrm{~cm})$. Cse. $1, \mathrm{Y} 32 / 1(95 \times)$

5. Cse., L38/2 $(95 \times)$

6. Cse., B26/1 $(95 \times)$

Figures 7, 8 Astrosphaerin sp. F.

7. Cse. F, R10/0 $(95 \times)$

8. Cse., R6/1 $(95 \times)$ 
PLATE 6

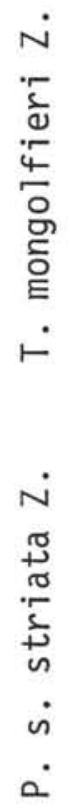

N

ז

든

$\dot{0}$

N
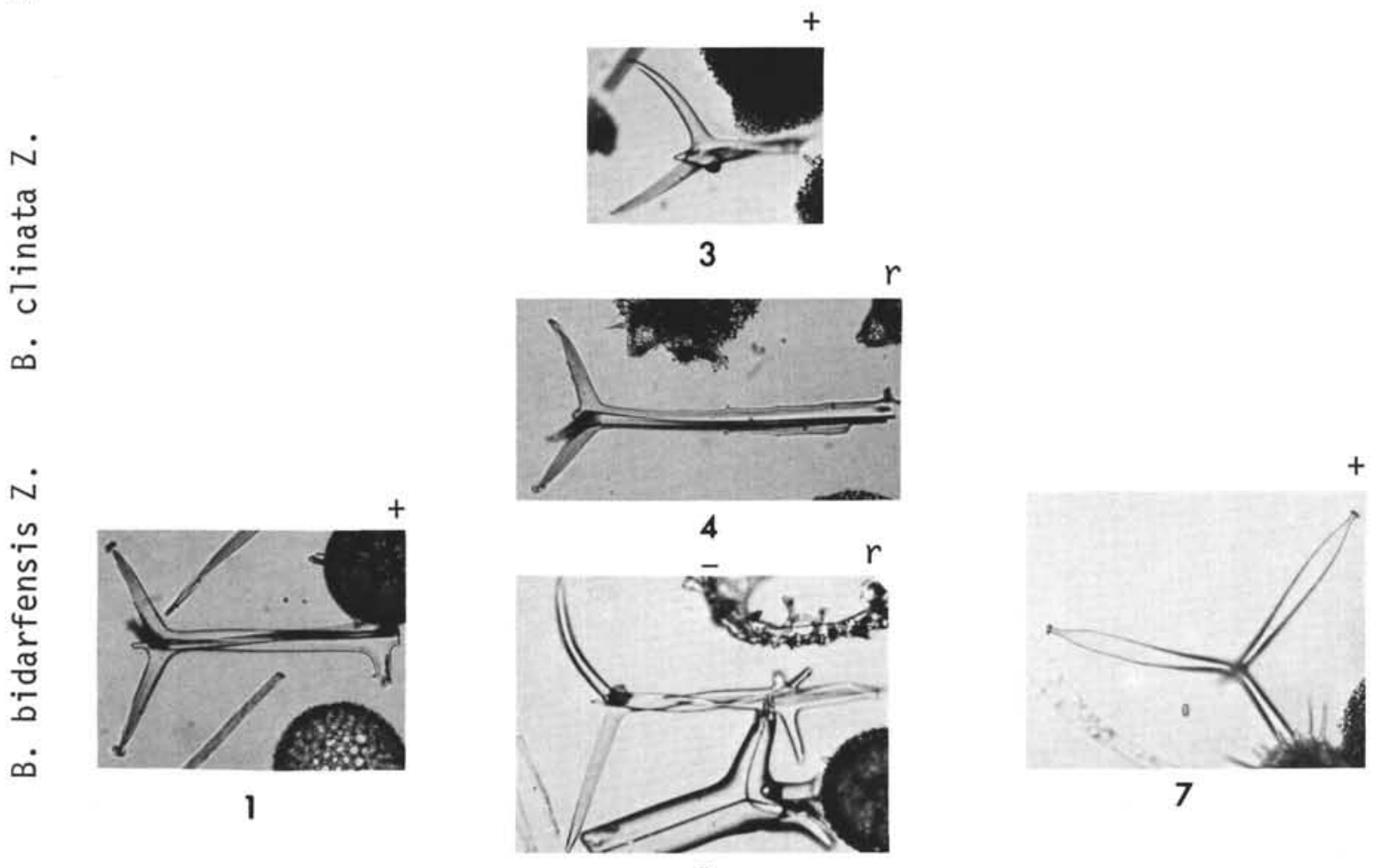

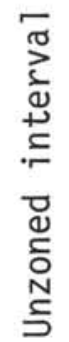

5
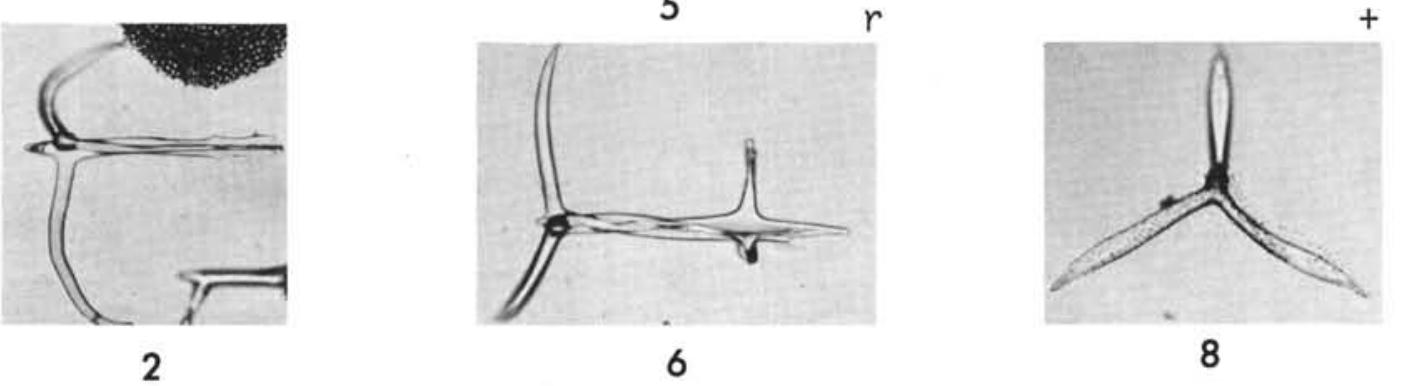
PLATE 7

Figures 1-6 Lithelius foremanae Sanfilippo and Riedel, n. sp.

1. Cse. $1, \mathrm{P} 23 / 0(95 \times)$

2. Sl. $1, \mathrm{U} 22 / 2(95 \times)$

3. Sl. $1, \mathrm{~B} 34 / 2(95 \times)$

4. Sl. $1, X 45 / 3(95 \times)$

5. Sl. A, L $42 / 2(95 \times)$

6. Cse. $1, \mathrm{M} 40 / 3(95 \times)$

Figures 7-9 Lithelius hexaxyphophorus (Clark and Campbell)

7. Cse. $1, \mathrm{~T} 18 / 4(95 \times)$

8. Cse. $5, \mathrm{~T} 37 / 3(95 \times)$

9. Cse. $1, \mathrm{~N} 23 / 3(95 \times)$

Figure 10 Actinommid gen. et. sp. idet.

Cse. $1, \mathrm{~K} 32 / 1(95 \times)$

Figures 11, 12 Astrophacus linckiaformis (Clark and Campbell)

11. Cse. $1, \mathrm{H} 45 / 3(95 \times)$

12. Cse. $1, \mathrm{~N} 15 / 0(95 \times)$ 
PLATE 7

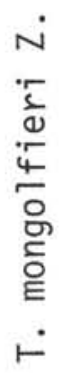
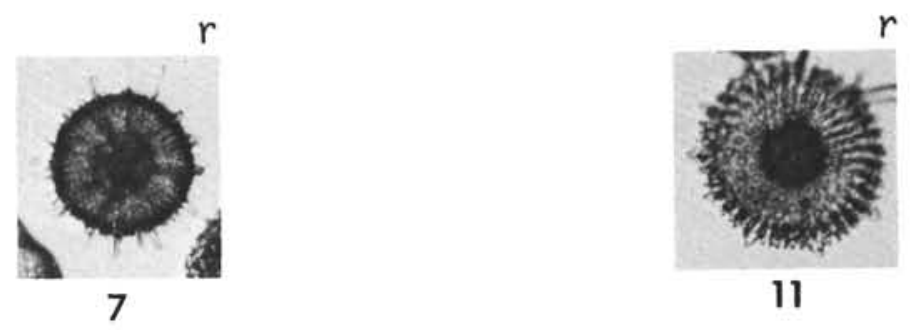

N

孚

is
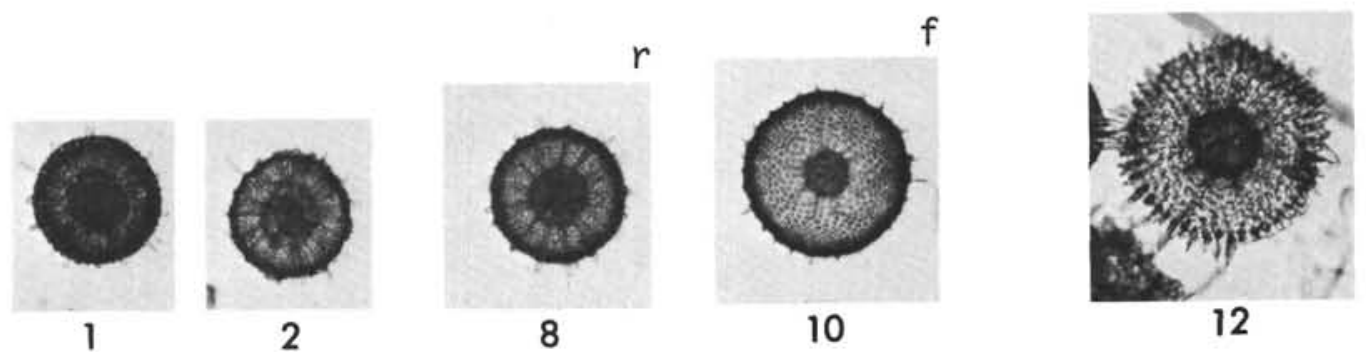

N

苞

ம
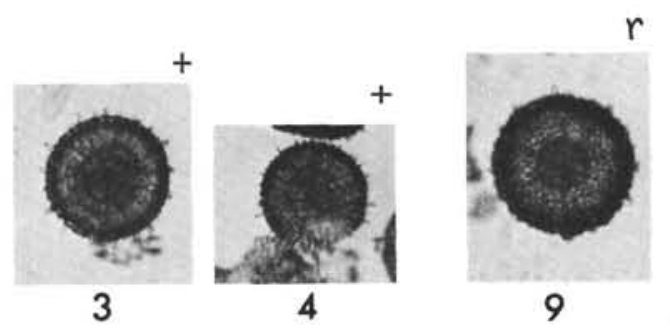

N

\begin{tabular}{l}
$n$ \\
$n$ \\
$\frac{n}{0}$ \\
4 \\
4 \\
$\frac{\pi}{0}$ \\
$\frac{\pi}{0}$ \\
\hline
\end{tabular}

๓

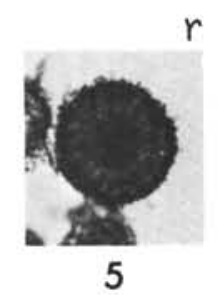

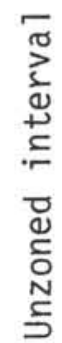

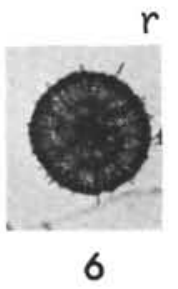


PLATE 8

Figures 1-7 Heliostylus spp.

1. Cse. $1, \mathrm{H} 32 / 2(60 \times)$

2. Cse. $1, \mathrm{~V} 49 / 1(95 \times)$

3. Cse. $1, \mathrm{~K} 11 / 2(95 \times)$

4. Cse. $1, \mathrm{U} 31 / 3(95 \times)$

5. Cse. G, Q12/2 $(95 \times)$

6. Cse. F, J27/3 (95X)

7. Cse. A, K12/0 (60X)

Figures 8-10 Periphaena decora Ehrenberg

8. Cse. $1, \mathrm{~S} 42 / 3(95 \times)$

9. Sl. $1, \mathrm{Y} 41 / 2(95 \times)$

10. Cse. $1, \mathrm{~K} 51 / 2(95 \times)$

Figures 11, 12 Periphaena delta Sanfilippo and Riedel, n. sp.

11. Cse. 1, Q25/2 $(95 \times)$

12. Sl. $1, \mathrm{E} 42 / 3(95 \times)$ 
PLATE 8
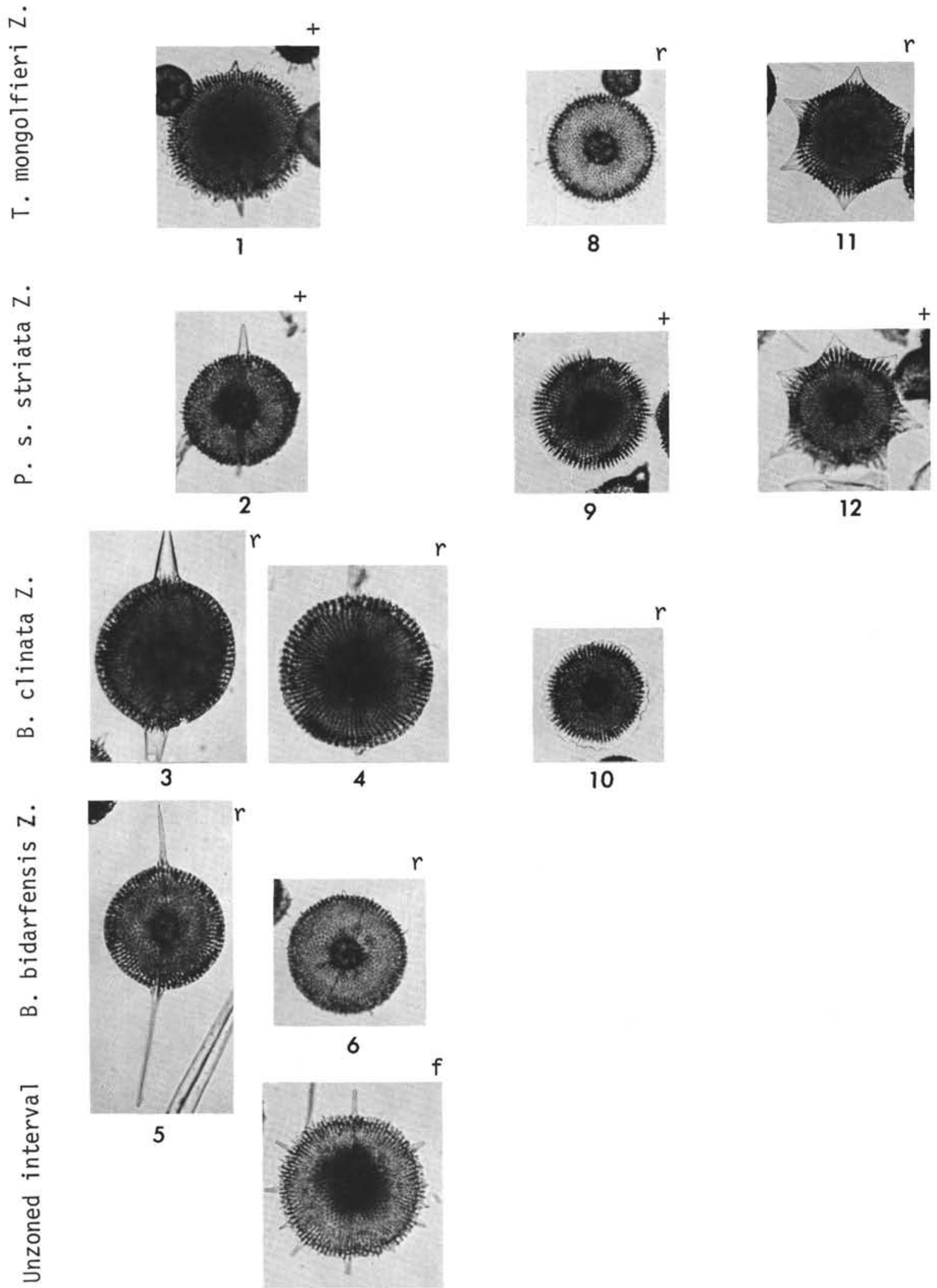


\section{PLATE 9}

Figures 1-6 Periphaena heliasteriscus (Clark and Campbell)

1. Cse. $1, \mathrm{~S} 34 / 4(95 \times)$

2. Sl. $1, X 41 / 0(95 \times)$

3. Cse. $1, \mathrm{~L} 42 / 4(95 \times)$

4. Cse. $1, \mathrm{~W} 49 / 0(95 \times)$

5. Cse. G, J27/4 (105X)

6. Cse. A, D37/3 $(95 \times)$

Figures 7-9 Periphaena tripyramis tripyramis (Haeckel)

7. Cse. $1, \mathrm{~N} 36 / 2(95 \times)$

8. Sl. $1, X 43 / 3(95 \times)$

9. Sl. $1, \mathrm{~N} 20 / 0(95 \mathrm{X})$

Figures 10, 11 Periphaena tripyramis triangula (Sutton)

10. Cse. 1 , U14/0 $(95 \times)$

11. Cse. $1, \mathrm{~J} 28 / 3(105 \times)$ 

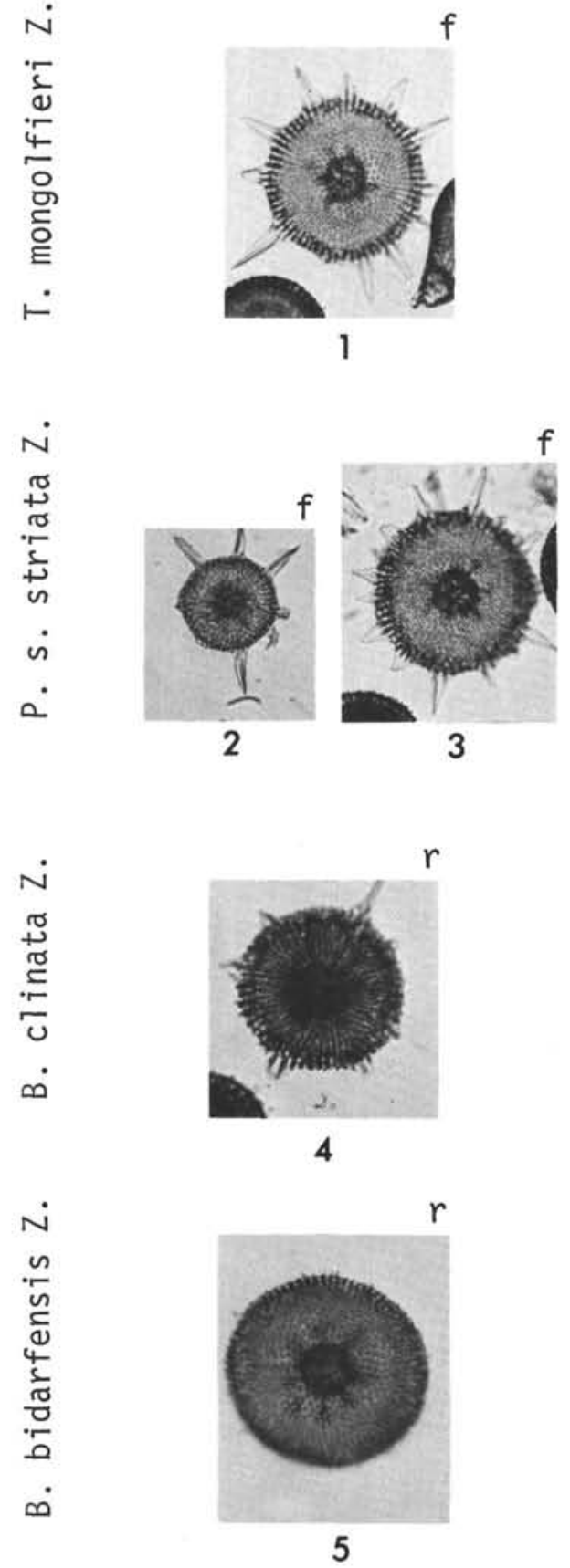

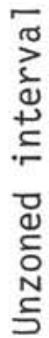

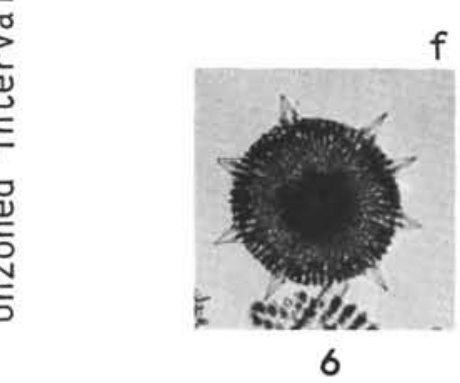

PLATE 9
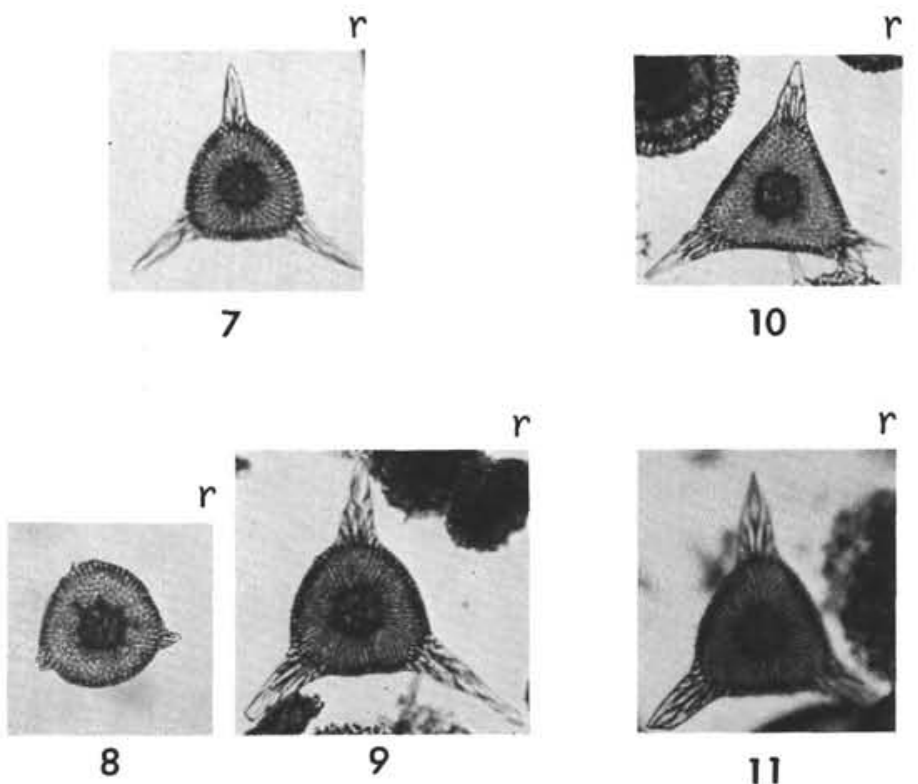

11 


\section{PLATE 10}

Figures 1, 2 Lithocyclia ocellus Ehrenberg group

1. Cse. $1, \mathrm{~F} 36 / 1(95 \times)$

2. Cse. $1, \mathrm{~W} 48 / 3(95 \times)$

Figures 3-6 Amphicraspedum murrayanum Haeckel

3. Cse. $1, \mathrm{~K} 21 / 4(95 \times)$

4. Cse. $2, \mathrm{R} 27 / 0(95 \times)$

5. Cse. G, X13/1 $(95 \times)$

6. Cse. G, U14/4 $(95 \times)$

Figures 7-11 Amphicraspedum prolixum Sanfilippo and Riedel group

7. Cse. $1, \mathrm{Y} 15 / 0(60 \times)$

8. Sl. $1, \mathrm{G} 30 / 4(95 \times)$

9. Cse. $1, \mathrm{E} 40 / 1(95 \times)$

10. Cse. G, N15/2 $(95 \times)$

11. Cse. G, U30/4 (60×) 


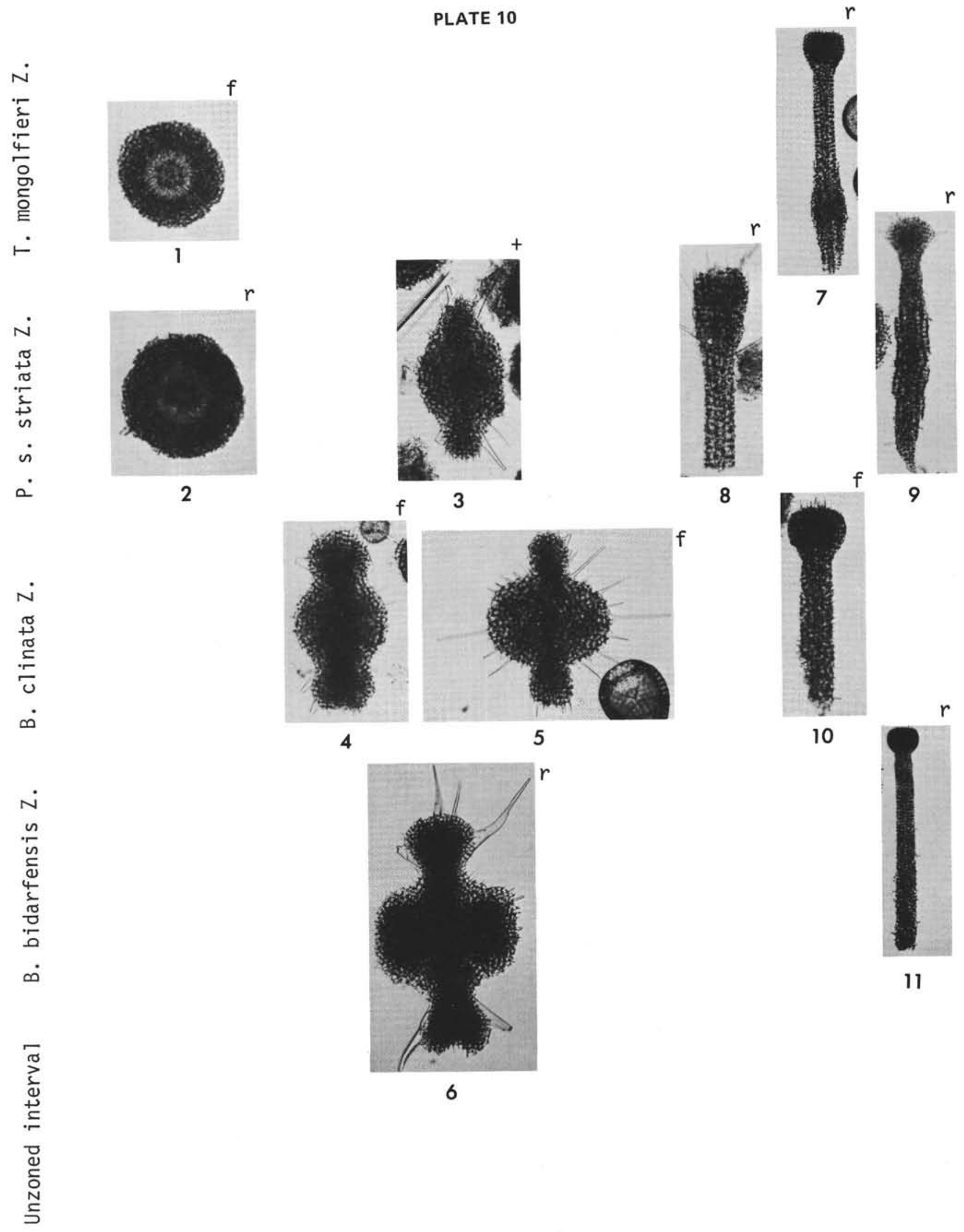


PLATE 11

Figures 1-5 Amphicraspedum prolixum Sanfilippo and Riedel group

1. Cse. $1, \mathrm{X} 14 / 0(95 \times)$

2. $94-22-1(42-44 \mathrm{~cm})$, Cse. A, G50/0 (95 $\times)$

3. $94-28-2(42-44 \mathrm{~cm})$, Cse. $2, \mathrm{U} 32 / 2(95 \times)$

4. $94-30-2(44-46 \mathrm{~cm})$, Cse. G, T16/3 (60X)

5. Cse. G, V33/1 (95X)

Figures 6-8 Amphymenium splendiarmatum Clark and Campbell

6. Sl. $2, \mathrm{M} 32 / 2(165 \times)$

7. Sl. $2, M 41 / 1(165 \times)$

8. Sl. $1, \mathrm{~V} 10 / 0(165 \times)$

Figures 9-13 Spongodiscus americanus Kozlova

9. $94-22-1(42-44 \mathrm{~cm})$, Cse. C, T22/0 (95×)

10. Cse.1, S19/4 $(95 \times)$

11. Cse. 2, N31/4 $(95 \times)$

12. Cse. G, U23/1 $(95 \times)$

13. Cse. $1, \mathrm{R} 26 / 0(95 \times)$

Figures 14-17 Spongodiscus cruciferus Clark and Campbell

14. $94-22-1(42-44 \mathrm{~cm})$, Cse. C, Q27/4 $(95 \times)$

15. Sl. $1, \mathrm{~N} 12 / 0(95 \times)$

16. Cse. $2, \mathrm{~L} 31 / 3(95 \times)$

17. Cse. G, O30/0 $(95 \times)$

Figures 18, 19 Spongodiscus sp.

18. 96-4-CC, Sl. 1A, F30/3 $(105 \times)$

19. Cse. A, T18/3 $(105 \times)$ 

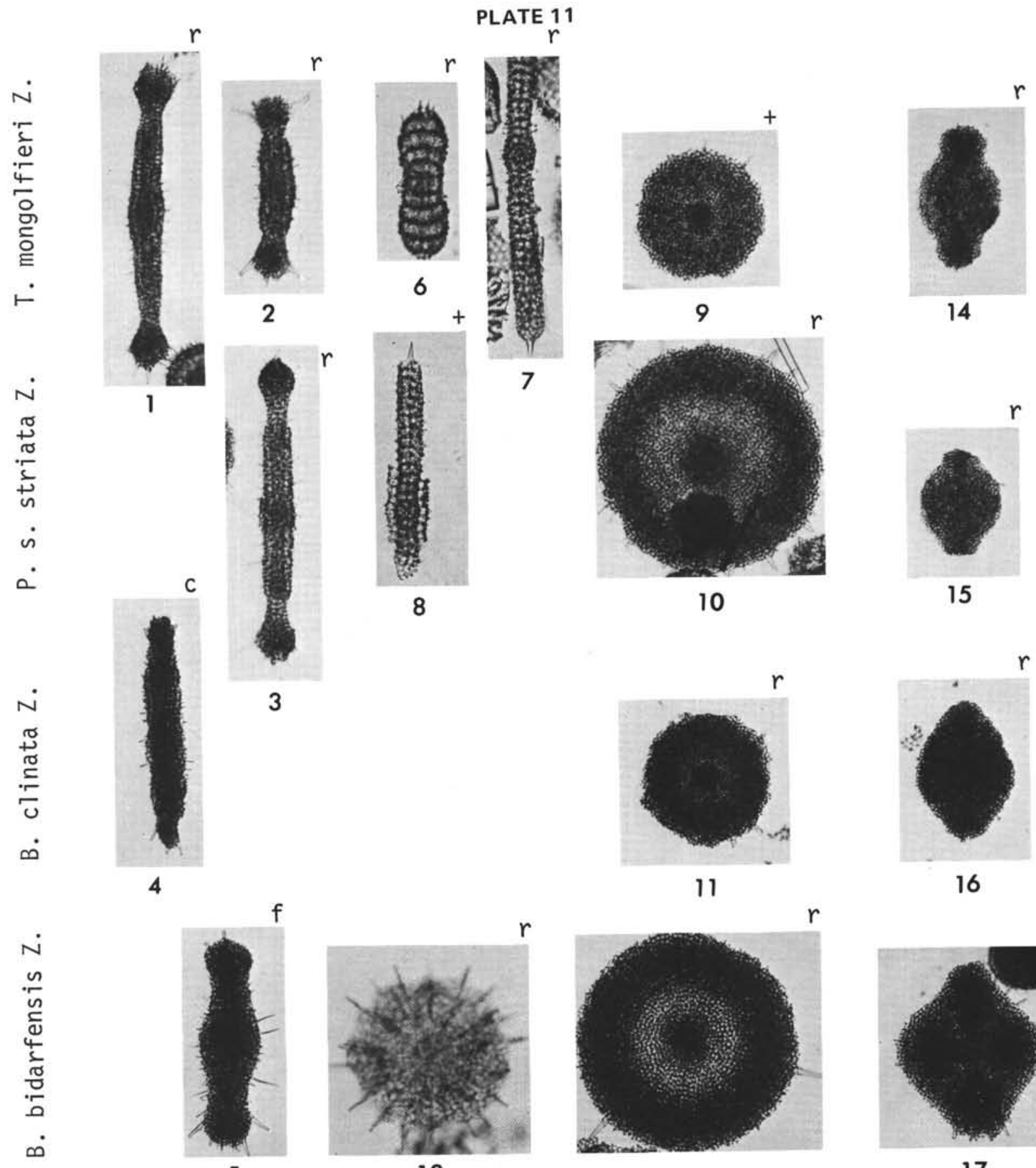

5

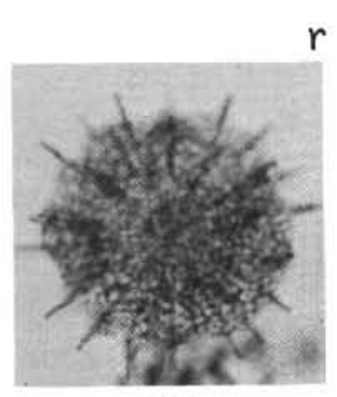

18

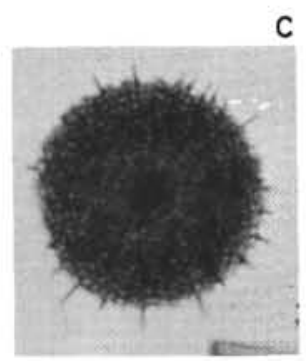

19

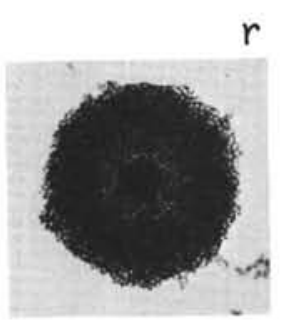

11

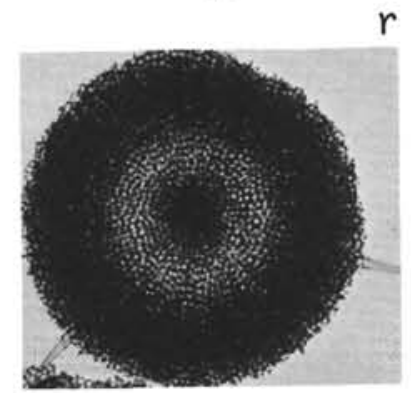

12

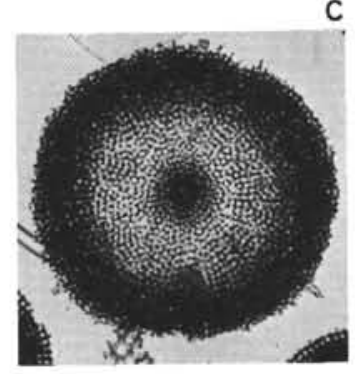

13 
PLATE 12

Figures 1, 2 Spongodiscus phrix Sanfilippo and Riedel, n. sp.

1. Cse. $1, \mathrm{U} 26 / 3(95 \times)$

2. $94-28-2(42-44 \mathrm{~cm})$, Cse. 2 , W34/0 (95×)

Figures 3-5 Spongodiscus pulcher Clark and Campbell

3. Cse. 1, L30/3 $(95 \times)$

4. Cse. $1, \mathrm{U} 39 / 0(95 \times)$

5. Cse. $1, \mathrm{M} 23 / 0(95 \times)$

Figures 6, 7 Spongodiscus quartus quartus (Borisenko)

6. Cse. G, P45/4 $(95 \times)$

7. Cse. F, S24/4 $(95 \times)$

Figures 8-10 Spongodiscus quartus bosoculus Sanfilippo and Riedel, n. subsp.

8. Sl. 1, W33/3 $(95 \times)$

9. Cse. G, $029 / 3(95 \times)$

10. Cse. $1, \mathrm{U} 37 / 4(95 \times)$ 
CENOZOIC RADIOLARIA

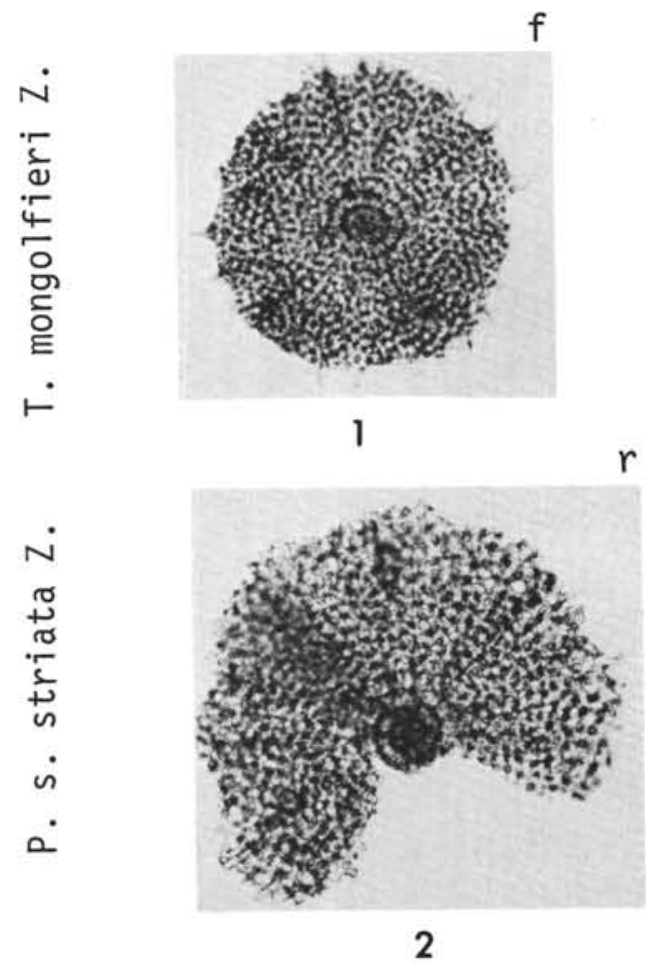

N

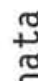

先

•

N

次

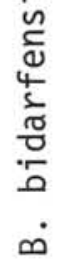

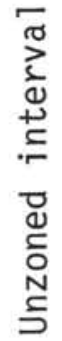

PLATE 12
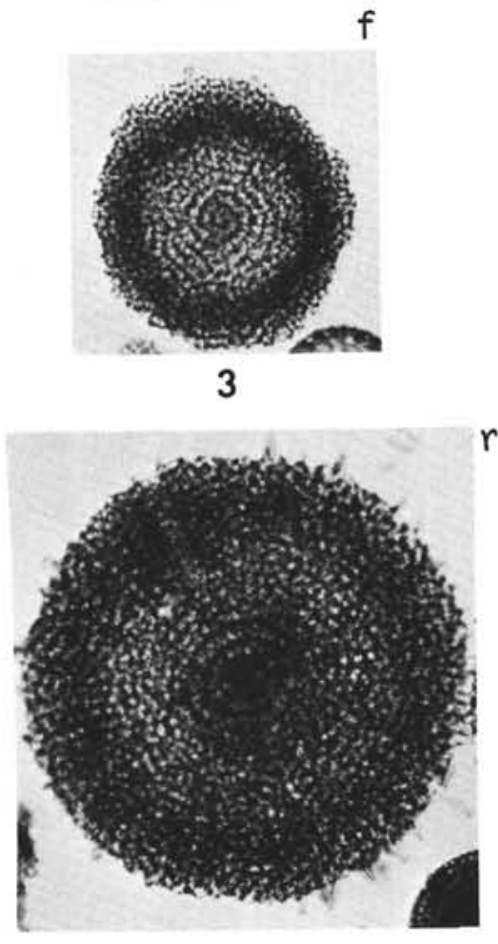

4
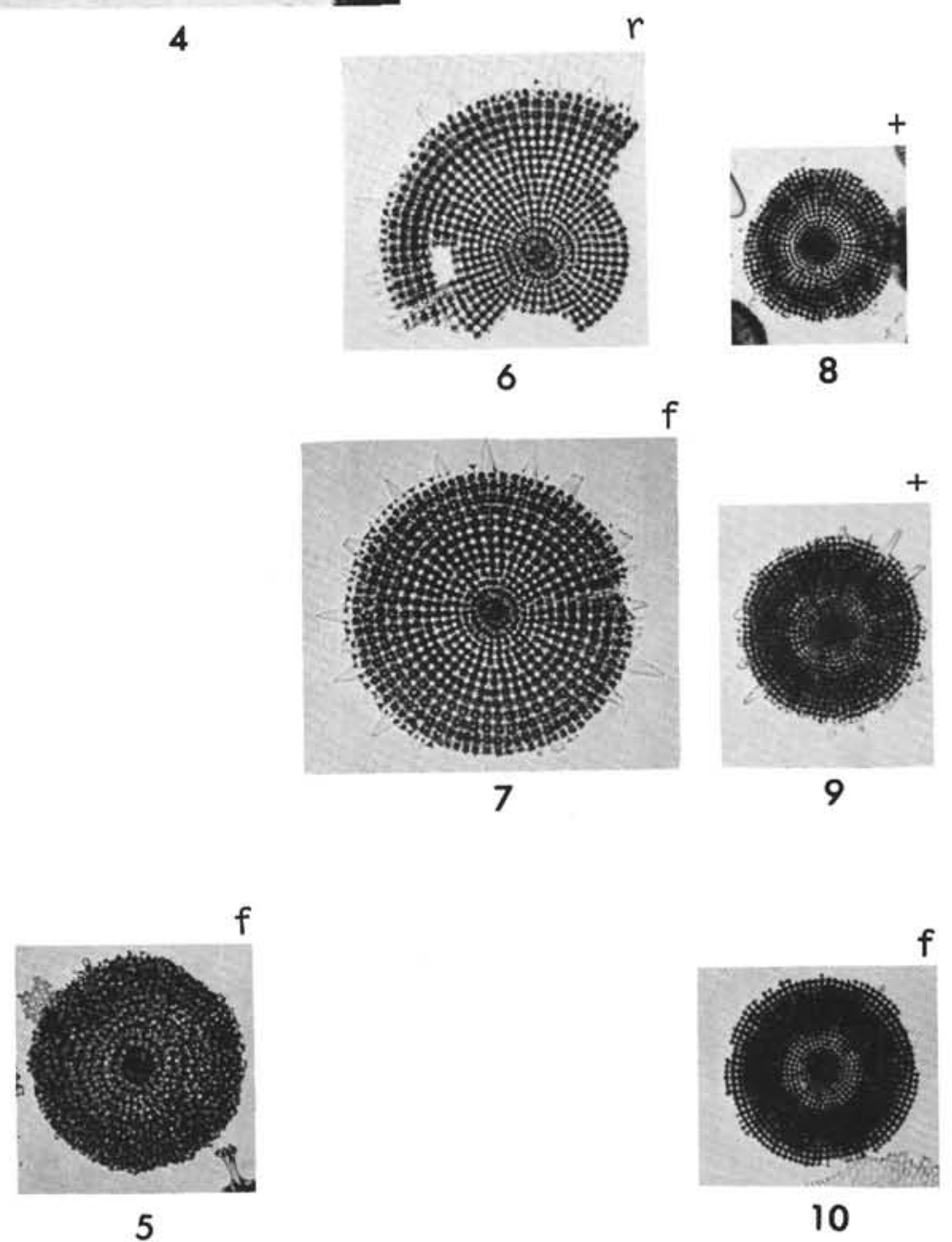


\section{PLATE 13}

Figures 1-3 Spongodiscus rhabdostylus (Ehrenberg)

1. Cse. $1, \mathrm{X} 41 / 4(95 \times)$

2. Cse. $1, \mathrm{~L} 28 / 1(95 \times)$

3. Cse. 2, H27/1 $(95 \times)$

Figures 4, 5 Stylotrochus alveatus Sanfilippo and Riedel, n. sp.

4. Cse. G, S21/3 $(95 \times)$

5. Cse. $1, \mathrm{~J} 34 / 0(95 \times)$

Figures 6-8 Stylotrochus charlestonensis (Clark and Campbell) ?

$$
\text { 6. S1. 1, 032/3 (95X) }
$$

7. Cse. $1, \mathrm{H} 15 / 3(95 \times)$

2, Y $37 / 3(95 \times)$

Figures 9-14 Stylotrochus nitidus Sanfilippo and Riedel, n. sp.

9. Cse. 2, D42/3 $(95 \times)$

10. Cse. $1, \mathrm{~S} 40 / 0(95 \times)$

11. Cse. $2, \mathrm{~T} 33 / 0(95 \times)$

12. Cse. G, J15/1 $(95 \times)$

13. Cse. G, C26/4 (95X)

14. Cse. 1, Q16/4 $(95 \times)$ 
PLATE 13
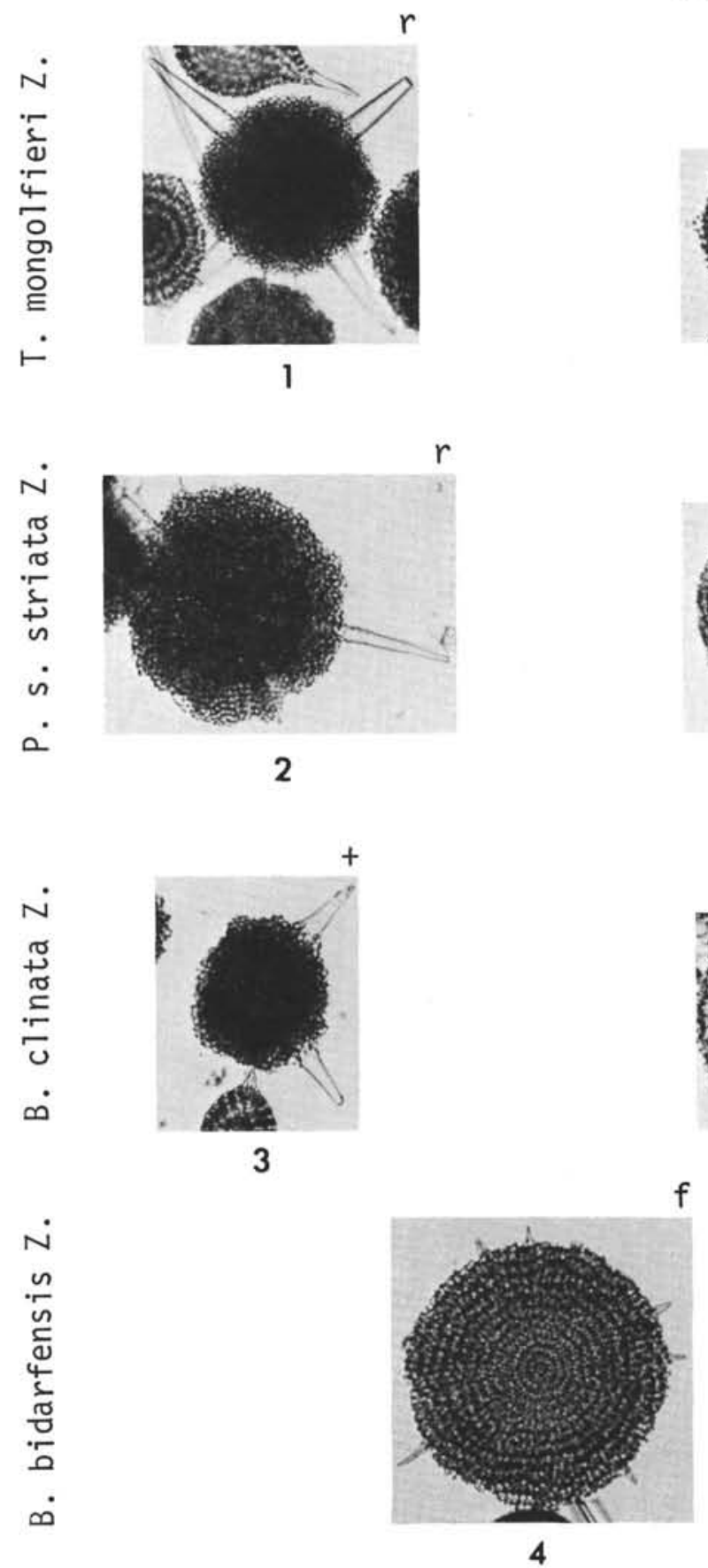

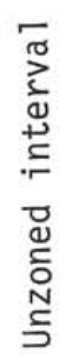

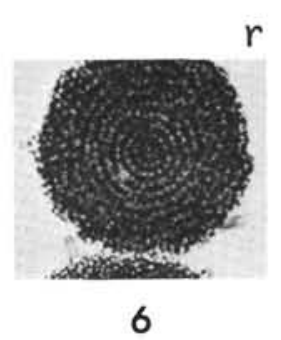

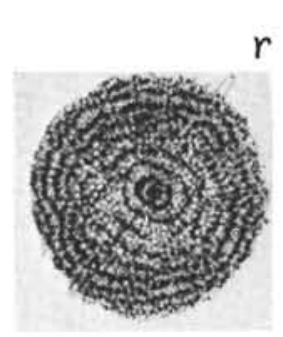

7

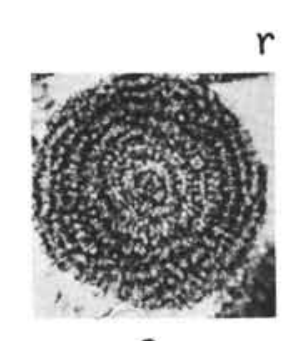

8
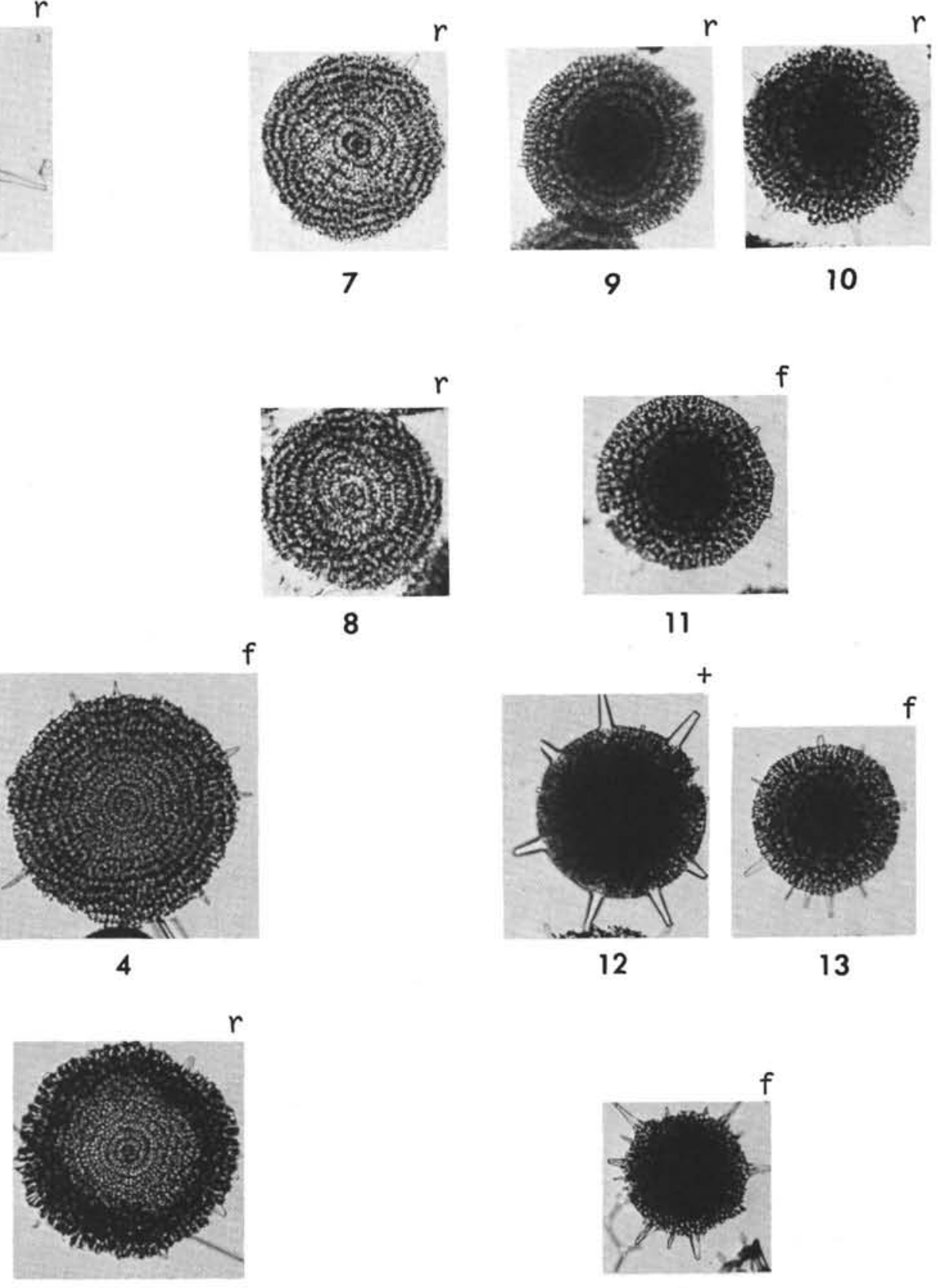

5

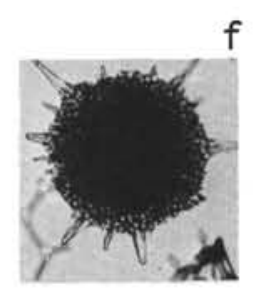

14 


\section{PLATE 14}

Figures 1,2 Stylotrochus quadribrachiatus quadribrachiatus Sanfilippo and Riedel, n. sp.

1. Cse. G, E23/1 (95X)

2. Cse. 2, W37/2 (95X)

Figures 3,4 Stylotrochus quadribrachiatus multibrachiatus Sanfilippo and Riedel, n. subsp.

3. $94-25-1(42-44 \mathrm{~cm})$, Cse. C, T16/0 (95X)

4. $94-25-2$ (42-44 cm), Cse., T13/1 (95X)

Figures 5-12, Xiphospira circularis (Clark and Campbell)
5. Cse. $1, X 33 / 4(95 X)$
6. Cse. $1, \mathrm{~S} 43 / 2(95 \mathrm{X})$
7. Cse. $1, N 19 / 0(95 X)$
8. Cse. G, W36/1 (95X)
9. Cse. $2, \mathrm{C} 36 / 0(95 \mathrm{X})$
10. Cse. G. S38/1 (95X)
11. Cse. G, V29/2 (95X)
12. Cse. $1, \mathrm{~S} 39 / 0(95 \mathrm{X})$ 
PLATE 14
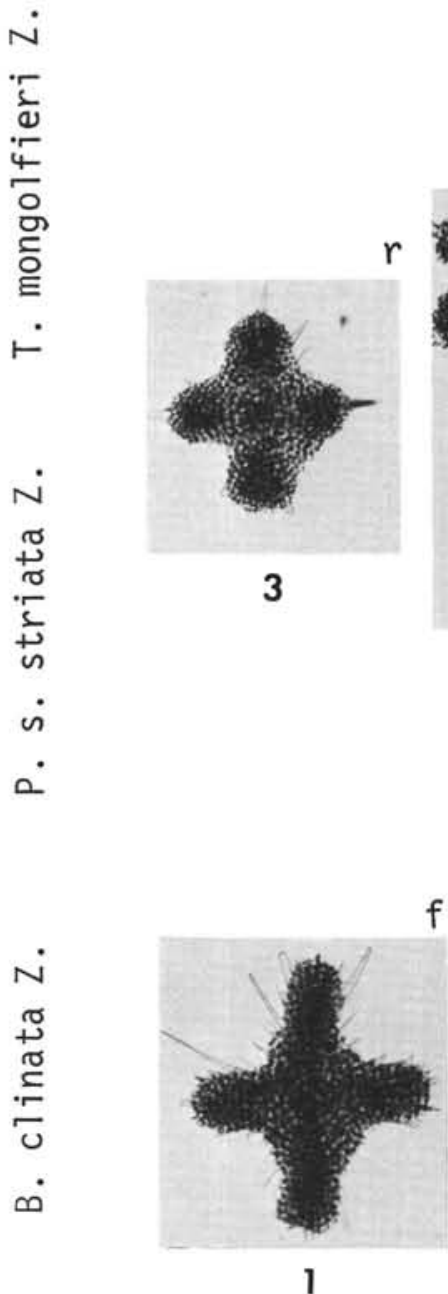

N

$\frac{n}{n}$
$\frac{n}{0}$
$\frac{4}{4}$
$\frac{\pi}{0}$
$\frac{0}{0}$
$\infty$
$\infty$

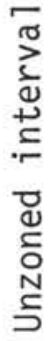
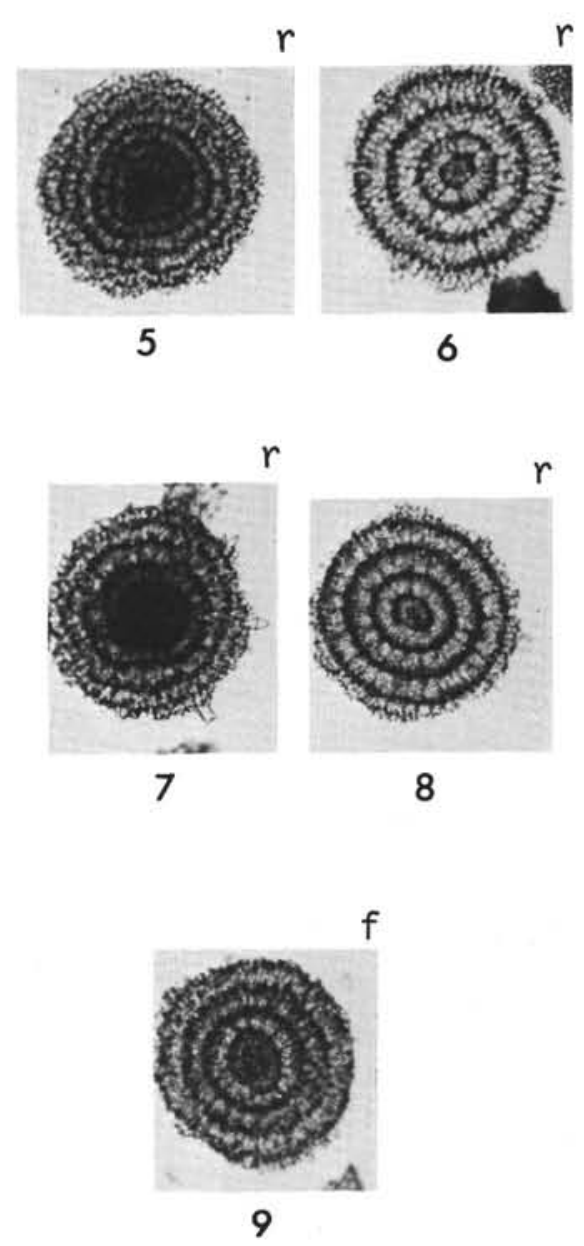

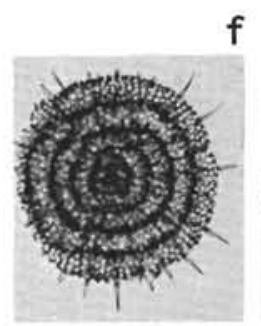

10

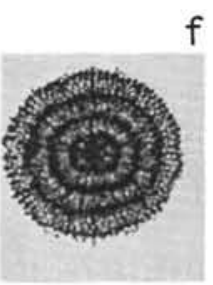

11

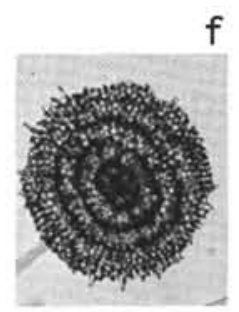


PLATE 15

Figures 1-3 Ceratospyris articulata Ehrenberg

1. S1. 2, M36/3 (165X)

2. Sl. $1, X 15 / 4(165 X)$

3. Ph. $2, \mathrm{~L} 10 / 1(165 \mathrm{X})$

Figure $4 \quad$ Ceratospyris (?) sp.

Sl. 2, T38/3 (165X)

Figure 5 Dendrospyris acuta Goll

S1. 1, P47/2 (165X)

Figures 6, 7 Dendrospyris aff. D. acuta Goll

6. Ph. 2, Y33/2 (165X)

7. $\mathrm{Ph} .2, \mathrm{U} 15 / 2(165 \mathrm{X})$

Figures 8-13 Dendrospyris fragoides Sanfilippo and Riedel, n. sp.

8. Sl. 2, T41/0 (165X)

9. Sl. $1, \mathrm{~V} 23 / 3(165 \mathrm{X})$

10. Ph. $2,017 / 3(165 X)$

11. Ph. $2, \mathrm{~N} 22 / 4(165 \mathrm{X})$

12. Sl. A, K45/1 (165X)

13. Slide " $<124 \mu \mathrm{A}$ ", Y41/2 (165X) 
PLATE 15
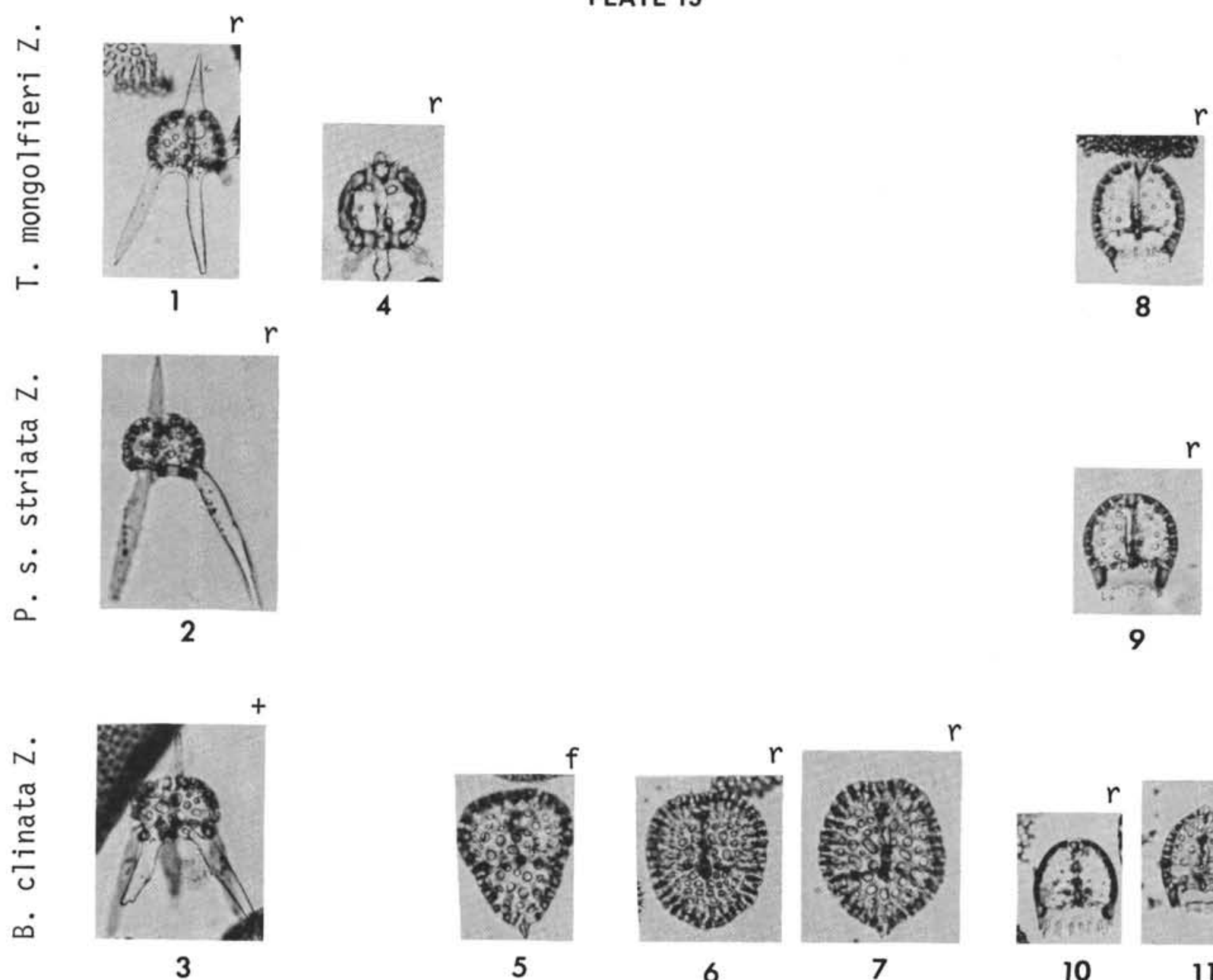

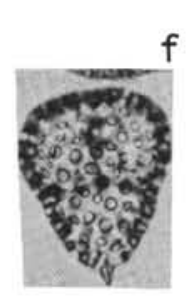

5

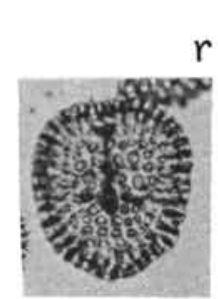

6

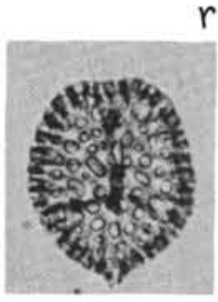

7

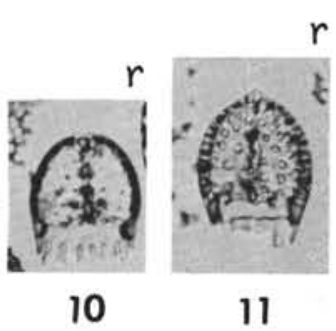

N

$\frac{n}{n}$

$\frac{n}{d}$
4
$\frac{1}{0}$
$\frac{\pi}{0}$
$\frac{1}{6}$

$\dot{\infty}$

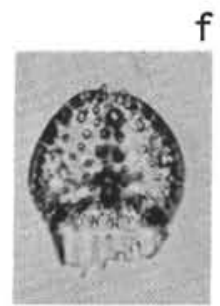

12

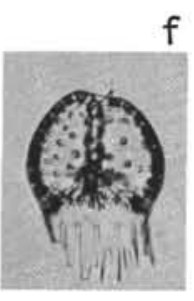

13

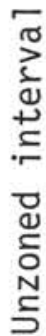




\section{PLATE 16}

Figure 1

Figure 2

Figure 3

Figures $4-8$

Figures 9,10
Dendrospyris tirriturcica tirriturcica Sanfilippo and Riedel, n. sp.

S1. 1, V27/2 (165X)

Dendrospyris cf. D. tirriturcica Sanfilippo and Riedel 94-28-4 (42-44 cm), Sl. 2, N42/4 (165X)

Dendrospyris tirriturcica dasyotus Sanfilippo and Riedel, n. subsp.

94-28-3 (43-45 cm), Sl. C, V36/0 (180X)

Dictyospyris discus Sanfilippo and Riedel, n. sp.

4. Sl. $1, \mathrm{~V} 19 / 0(165 \mathrm{X})$

5. Ph. $2, \mathrm{~F} 26 / 0(165 \mathrm{X})$

6. Ph. $2, \mathrm{Y} 34 / 3(165 \mathrm{X})$

7. Slide " $<124 \mu \mathrm{A}$ ", $018 / 2(165 X)$

8. Slide " $<124 \mu \mathrm{A}$ ", $\mathrm{X} 23 /)(165 \mathrm{X})$

Dictyospyris gigas Ehrenberg

9. Sl. 1, U15/4 (165X)

10. Ph. $2, \mathrm{R} 37 / 0(165 \mathrm{X})$ 


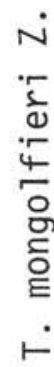
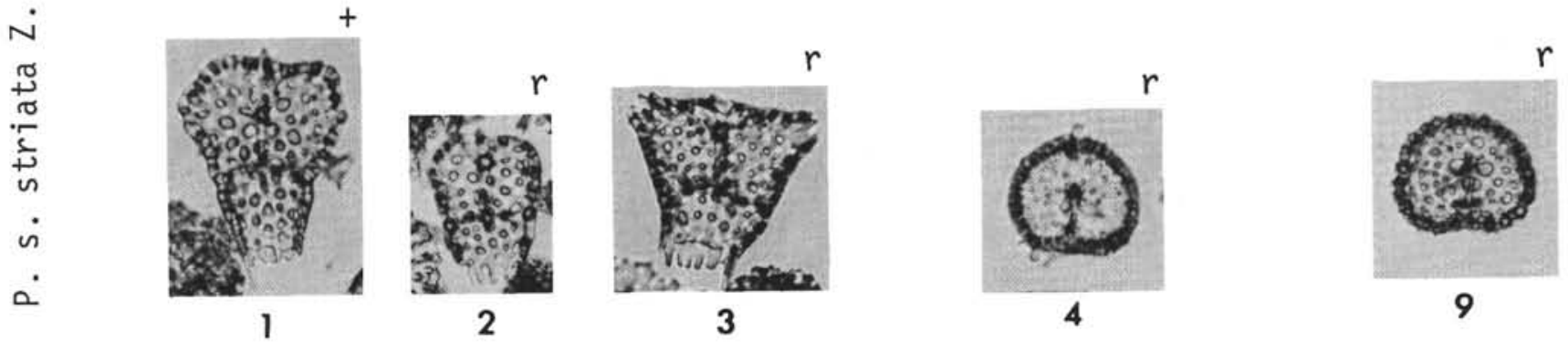

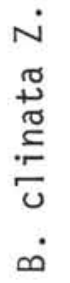

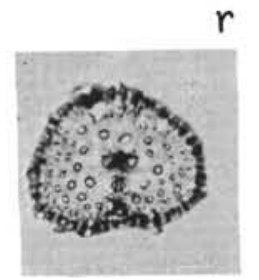

5

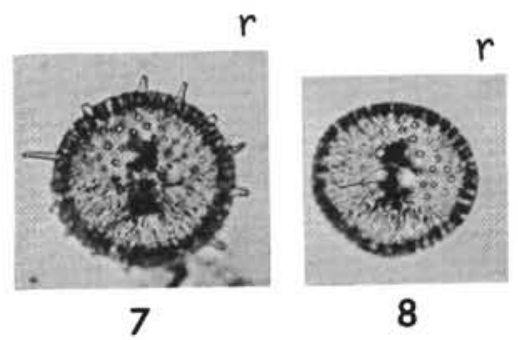

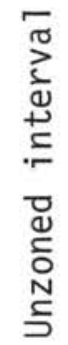




\section{PLATE 17}

Figures 1, 2 Dictyospyris melissium Sanfilippo and Riedel, n. sp.

1. S1. $1, \mathrm{~B} 26 / 4(165 \times)$

2. Sl. $1, \mathrm{~F} 31 / 1(165 \times)$

Figures 3-5 Dictyospyris sphaera Bütschli

3. Sl. $2, X 38 / 4(165 \times)$

4. Sl. $1, \mathrm{D} 33 / 0(165 \times)$

5. $\mathrm{Ph} .2, \mathrm{Z13} / 2(165 \times)$

Figures 6-10 Dorcadospyris confluens (Ehrenberg)
6. Sl. 2, M20/1 $(180 \times)$
7. Sl. $1, \mathrm{R} 14 / 1(165 \times)$
8. Sl. $1, \mathrm{H} 49 / 2(165 \times)$
9. Sl. $1, X 41 / 4(165 \times)$
10. Slide " $<124 \mu \mathrm{A}$ ", J54/1 (165X)

Figures 11-15 Dorcadospyris platyacantha (Ehrenberg)

11. Sl. 2, U47/0 $(165 \times)$

12. Sl. $1, \mathrm{~T} 11 / 4(165 \times)$

13. Ph. $2, \mathrm{~N} 18 / 0(165 \times)$

14. Ph. $2, \mathrm{~T} 15 / 0(165 \times)$

15. Sl. G, B41/0 $(165 \times)$ 
PLATE 17

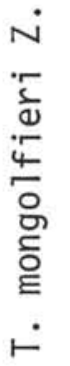

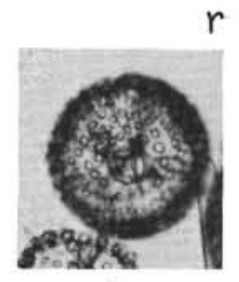

3

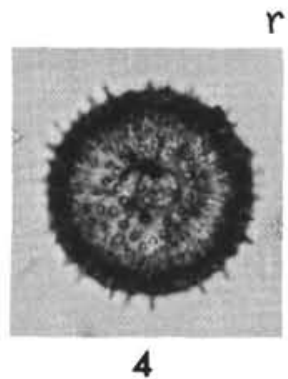

4

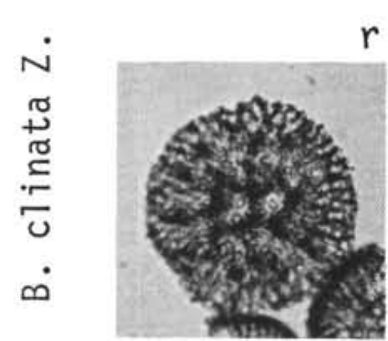

1

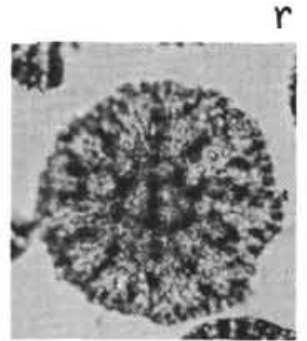

2

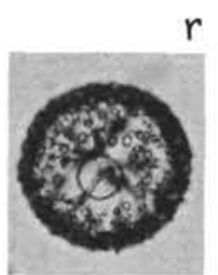

5

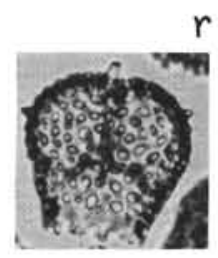

6
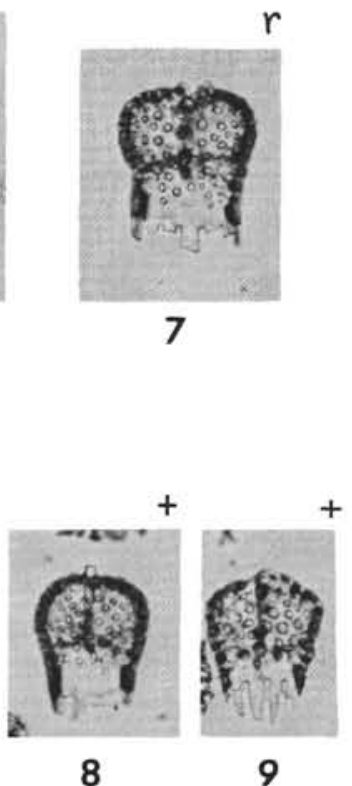

8

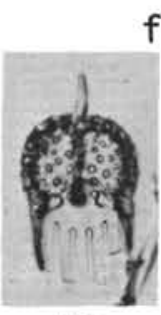

11
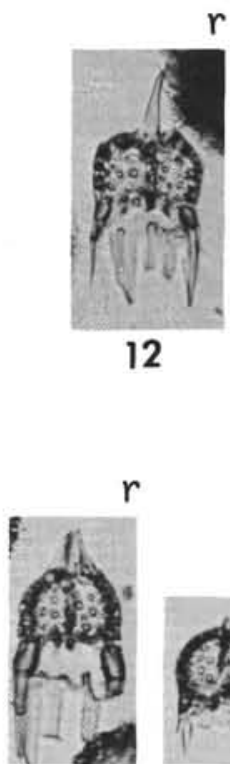

13

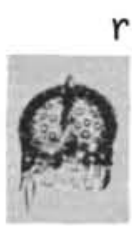

14

$n$
$n$
$\frac{n}{n}$
$\frac{1}{4}$
4
$\frac{\pi}{0}$
$\frac{0}{0}$
0
0

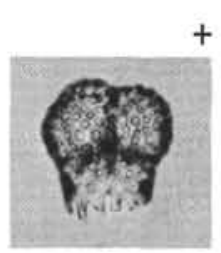

10

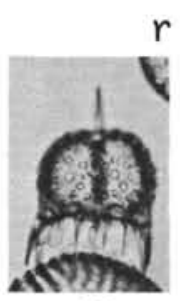

15

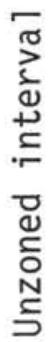




\section{PLATE 18}

Figures 1-3 Giraffospyris cyrillium Sanfilippo and Riedel, n. sp.

1. Ph. 2, J29/4 $(165 \times)$

2. Sl. $1, \mathrm{P} 24 / 3(165 \times)$

3. $\mathrm{Ph} .2, \mathrm{~L} 37 / 3(180 \times)$

Figures 4-7 Giraffospyris lata Goll

4. Sl. $1, \mathrm{R} 36 / 0(165 \times)$

5. $\mathrm{Ph} .2, \mathrm{H} 11 / 3(165 \times)$

6. Slide " $<124 \mu \mathrm{A}$ ", $038 / 4$ (165X)

7. Slide " $<124 \mu \mathrm{A}$ ", E23/0 (165X)

Figures 8-11 Rhabdolithis ellida Sanfilippo and Riedel, n. sp.

8. 94-28-4 (42-44 cm), S1. 2, N29/0 (165 $\times)$

9. $96-3-3(42-44 \mathrm{~cm})$, Cse. $1, \mathrm{X} 9 / 1(95 \times)$

10. Cse. E, L11/3 $(95 \times)$

11. Sl. A, T29/4 $(165 \times)$

Figures 12-16 Rhabdolithis pipa Ehrenberg

12. S1. 2, D22/3 (165×)

13. $94-28-4(42-44 \mathrm{~cm})$, Sl. $2, \mathrm{M} 38 / 4(180 \times)$

14. Cse. $1, \mathrm{Q} 45 / 3(165 \times)$

15. Sl. $1, \mathrm{H} 13 / 2(165 \times)$

16. $96-3-3$ (42-44 cm), Cse. 5, L39/3 (165×) 


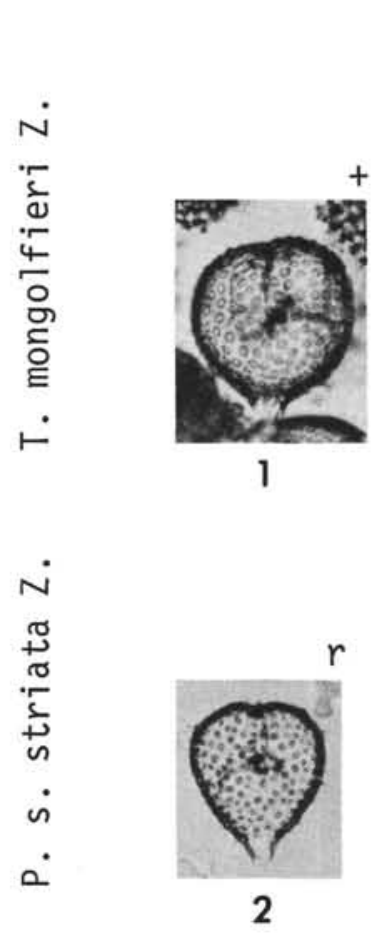

PLATE 18
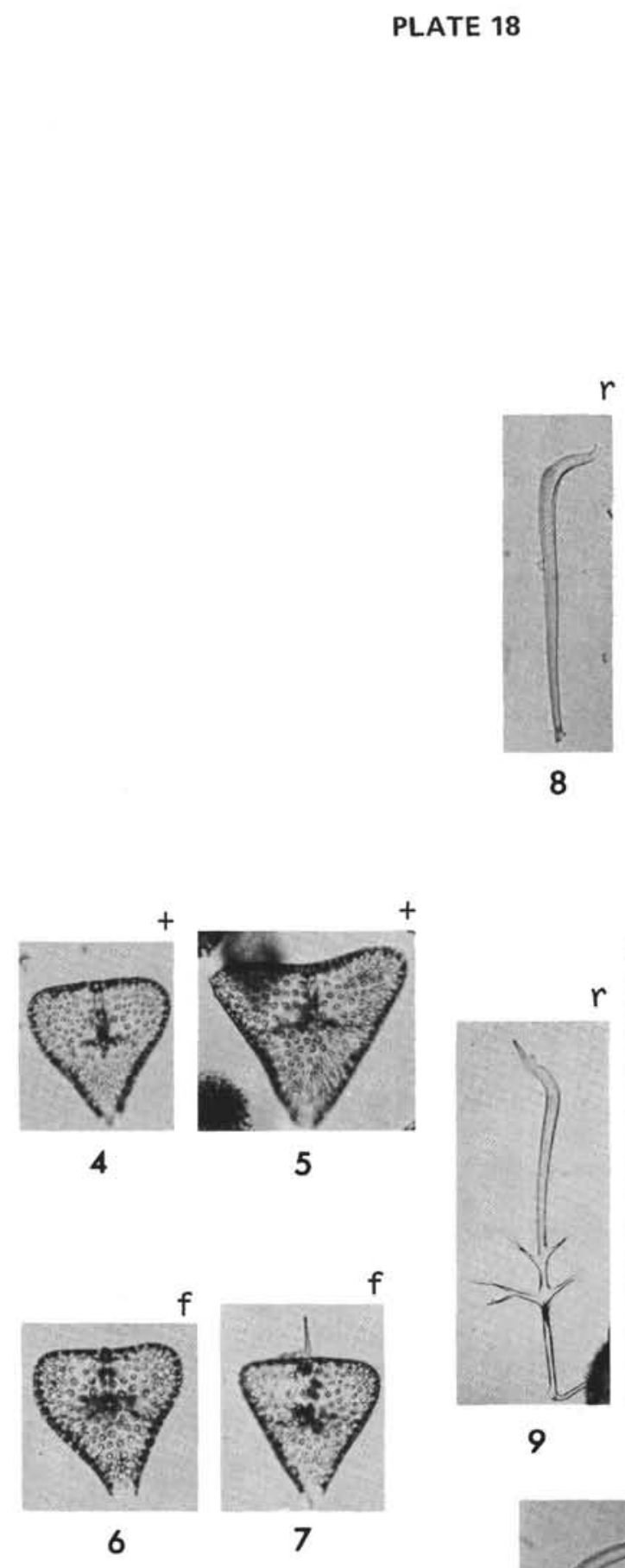

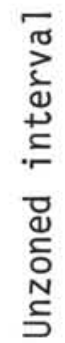

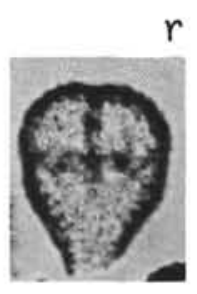

3

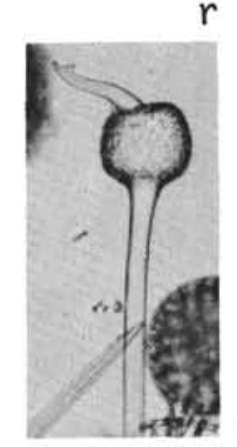

12
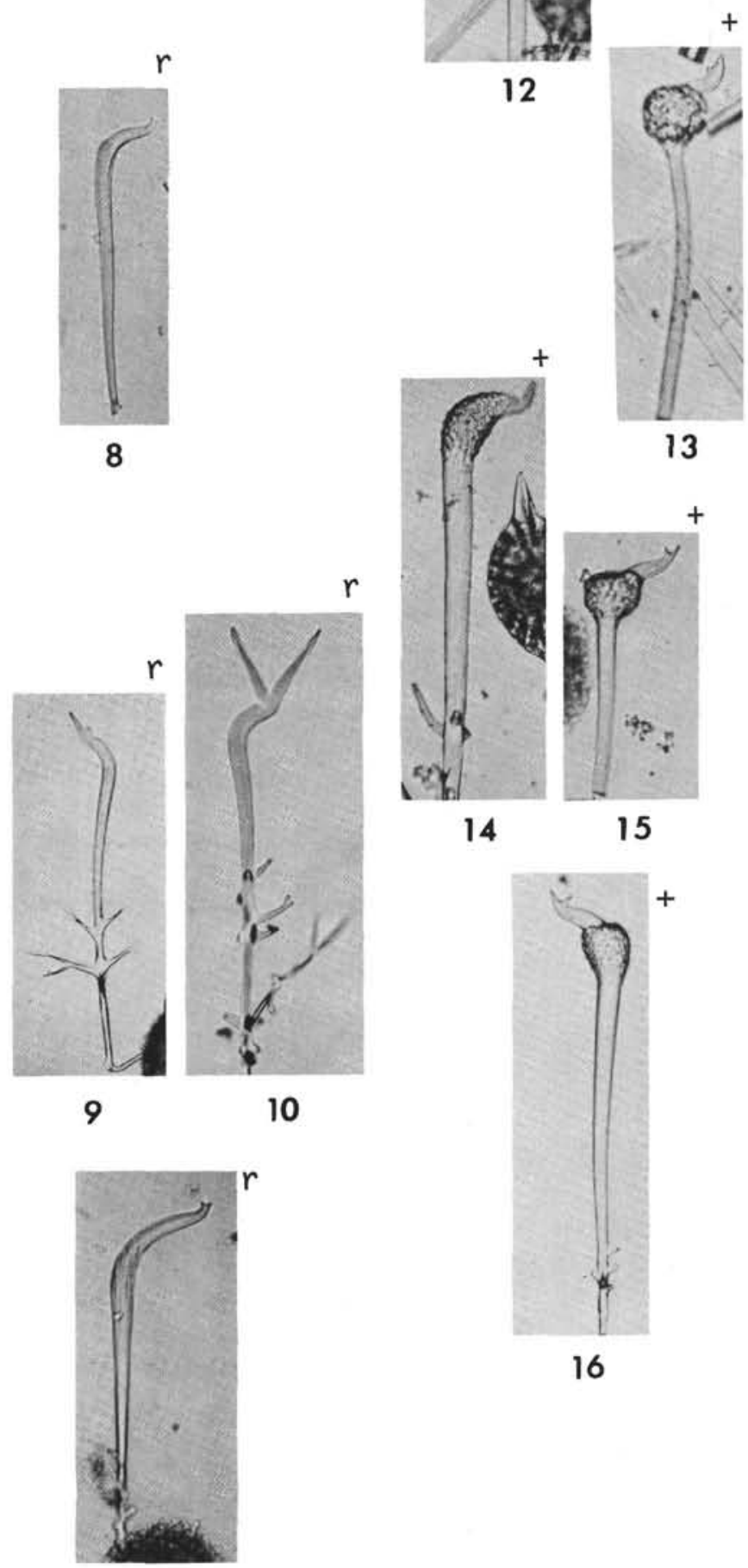

11 


\section{PLATE 19}

Figure 1 Dictyophimus craticula Ehrenberg

94-22-1 (42-44 cm), Cse. A, H17/2 (105×)

Figure 2 Dictyophimus sp. aff. D. craticula Ehrenberg Cse. A, T43/4 $(95 \times)$

Figures 3, $4 \quad$ Spongomelissa adunca Sanfilippo and Riedel, n. sp.

3. Cse. G, L19/1 $(95 \times)$

4. Cse. A, V46/2 $(95 \times)$

Figure $5 \quad$ Spongomelissa sp. aff. S. adunca Sanfilippo and Riedel

Cse. A, X27/0 (95 $\times)$

Figures 6, 7 Spongomelissa cucumella Sanfilippo and Riedel, $\mathrm{n}$. sp.

6. Ph. 1, M11/0 (165×)

7. $\mathrm{Ph} .1, \mathrm{R} 38 / 3(165 \times)$

Figure $8 \quad$ Plagoniid gen. et. sp. indet.

94-29 (CC), Sl. 5, C11/4 (165×) 
PLATE 19

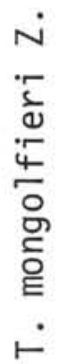
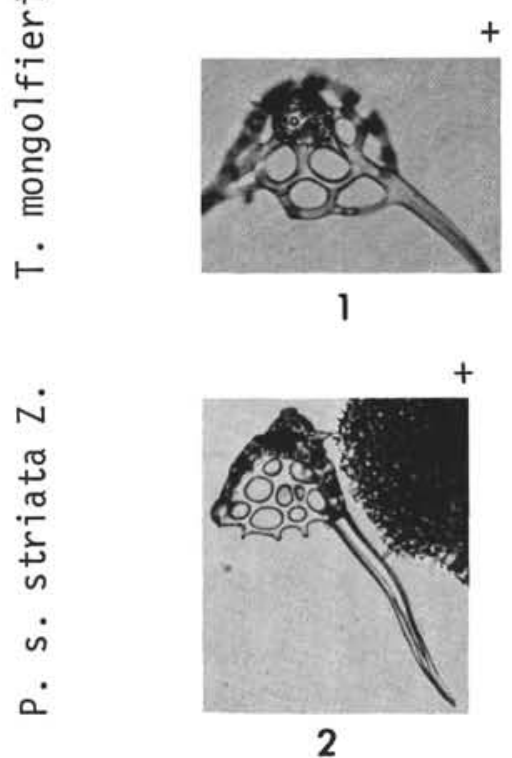

ن.
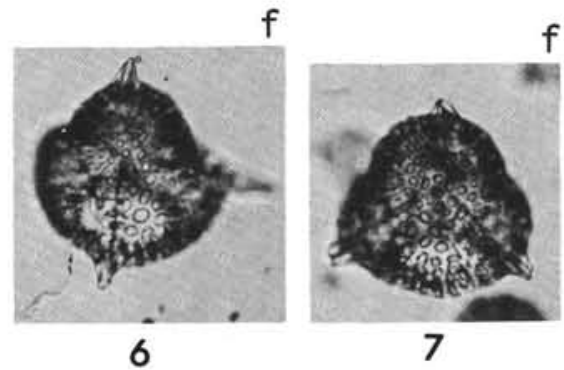

$n$
$n$
$\frac{n}{n}$
$\frac{1}{4}$
4
$\frac{\pi}{0}$
$\frac{\pi}{0}$
0
0

$r$

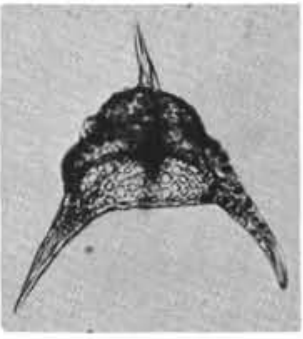

3

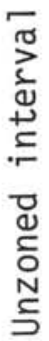

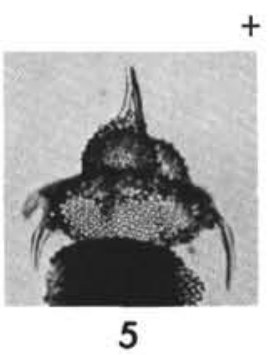


PLATE 20

Figure 1 Spongomelissa euparyphus Sanfilippo and Riedel, n. sp.

94-30-1 (80-82 cm), Cse. 1, E46/3 (95×)

Figures 2-6 Velicucullus $\mathrm{sp}(\mathrm{p})$.

2. $94-22-1(42-44 \mathrm{~cm})$, Cse. A, L35/2 $(105 \times)$

3. $94-28-1(113-115 \mathrm{~cm})$, Cse. C, D47/2 (105 $\times)$

4. $94-30-2(44-46 \mathrm{~cm})$, Cse. G, S37/0 (105 $\times)$

5. Cse. F, D38/1 $(105 \times)$

6. Cse. $1, \mathrm{Q} 44 / 3(95 \times)$

Figures 7, 8 Podocyrtis aphorma Riedel and Sanfilippo

7. Cse. 1, T33/1 (95X)

8. Cse. $2, \mathrm{~N} 25 / 1(95 \mathrm{X})$

Figures 9-10 Podocyrtis diamesa Riedel and Sanfilippo

9. Cse. $1, \mathrm{~N} 15 / 3(95 \times)$

10. Sl. $1, \mathrm{~L} 35 / 0(95 \times)$

Figures 11-14 Podocyrtis papalis Ehrenberg

11. Cse. $1, \mathrm{G} 29 / 4(95 \times)$

12. Sl. $1, \mathrm{~L} 32 / 3(95 \times)$

13. Sl. 1, S37/0 $(95 \times)$

14. Cse. F, W19/1 $(95 \times)$ 


\section{PLATE 20}

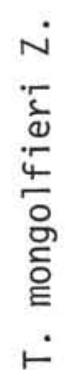

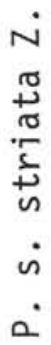

1

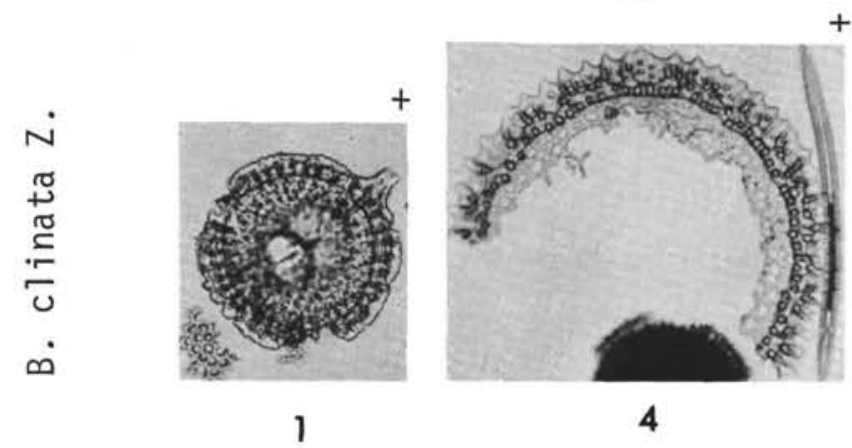

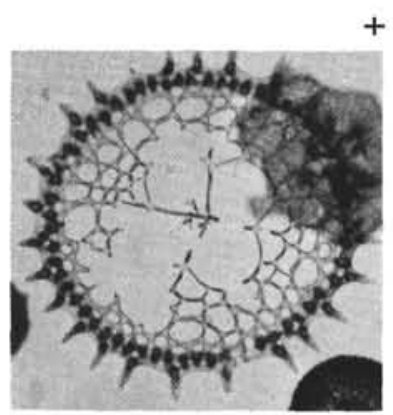

2

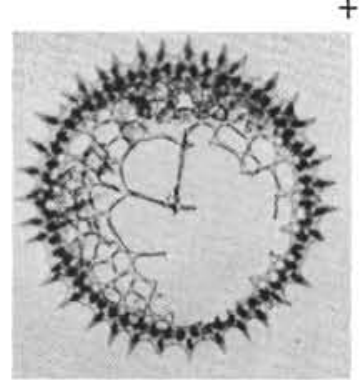

3

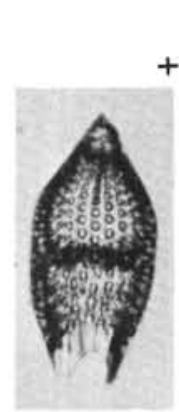

7

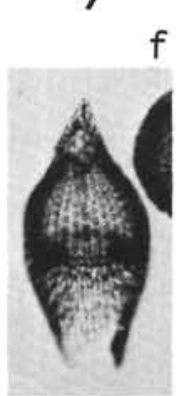

8

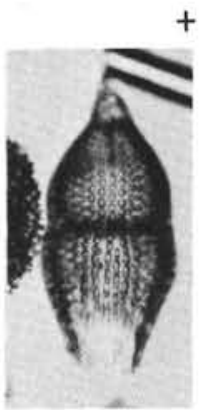

9

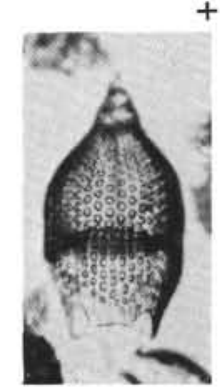

10

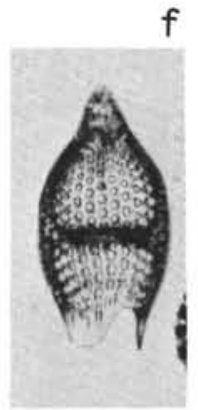

11

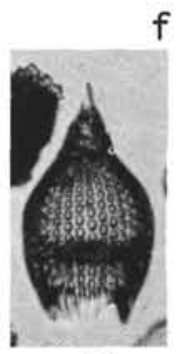

12

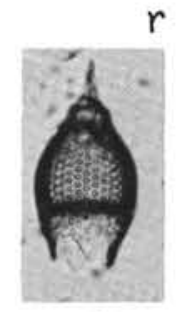

13

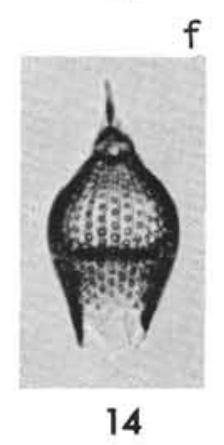

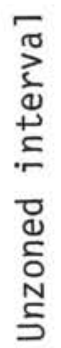

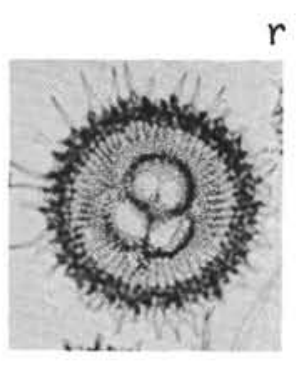




\section{PLATE 21}

Figures 1-3 Podocyrtis platypus Sanfilippo and Riedel, n. sp.

1. Cse. $1, \mathrm{~F} 13 / 3(95 \times)$

2. Sl. $1, \mathrm{C} 43 / 4(95 \times)$

3. Cse. $2, \mathrm{~J} 26 / 0(95 \times)$

Figures 4, $5 \quad$ Podocyrtis sinuosa Ehrenberg ?

4. Cse. $1, \mathrm{~T} 20 / 0(95 \times)$

5. Sl. $1, \mathrm{~N} 11 / 4(95 \times)$

Figures 6-13 Cannobotryids gen(n). et $\mathrm{sp}(\mathrm{p})$. indet.

6. Sl. 2, W11/0 (165X)

7. $94-28-2(42-44 \mathrm{~cm})$, Sl. $1, \mathrm{G} 13 / 2(165 \mathrm{X})$

8. $94-30-1(80-82 \mathrm{~cm}), \mathrm{Ph} .2$, W43/2 (165X)

9. $94-31$ (CC), Sl. 2, R14/3 (165X)

10. $94-31$ (CC), Sl. $2, \mathrm{~T} 46 / 3(165 \mathrm{X})$

11. $94-31$ (CC), Sl. 2, J26/0 (165X)

12. $96-3-4(42-44 \mathrm{~cm})$, Sl. $1, \mathrm{U} 20 / 4$ (165X)

13. $96-3$ (CC), Sl. 1, Q38/2 (165X) 
PLATE 21
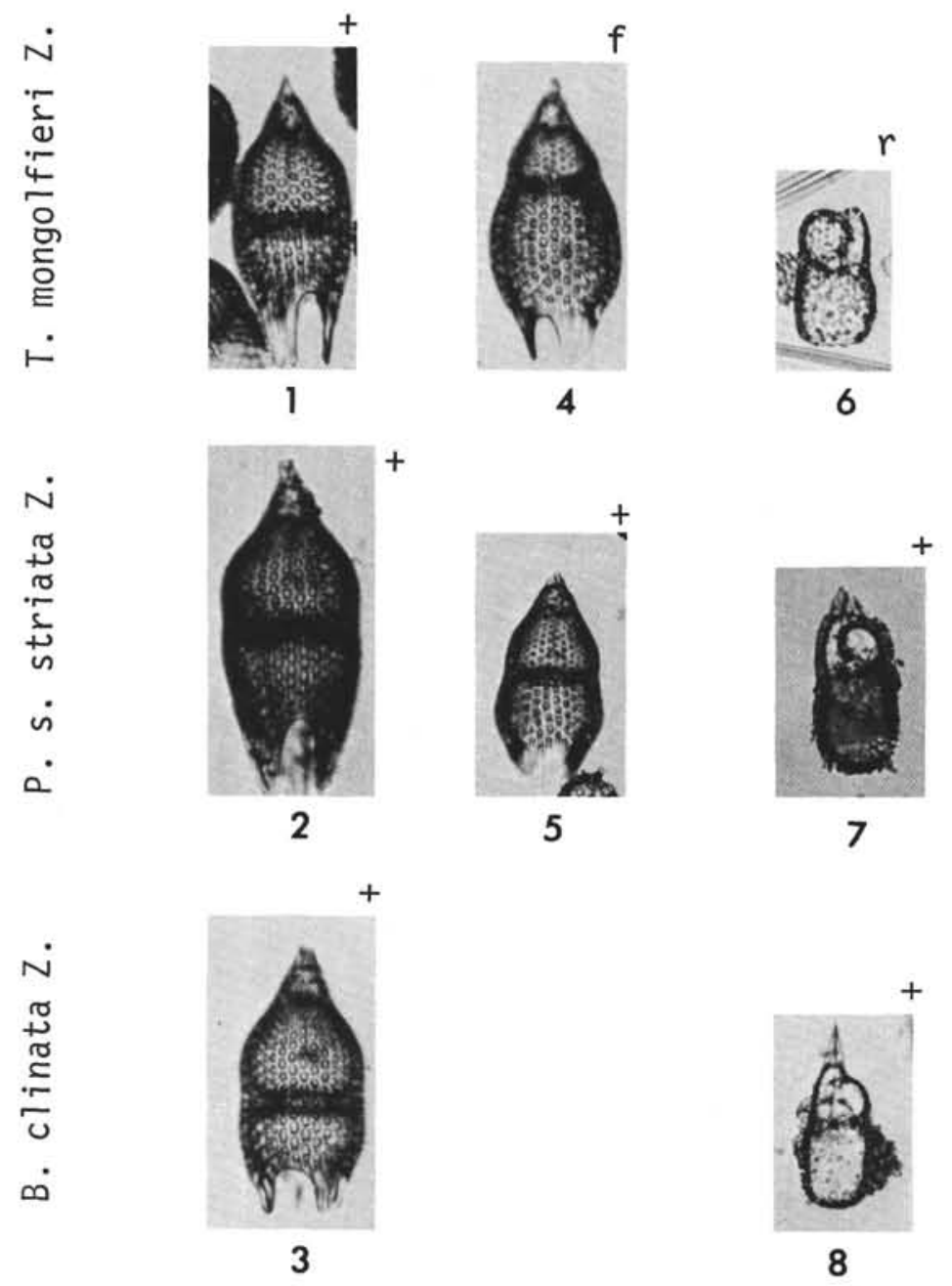

N

v

$N$
$n$
$n$
0
0
4
$\frac{1}{\pi}$
$\frac{0}{0}$
$\frac{0}{0}$
$\infty$
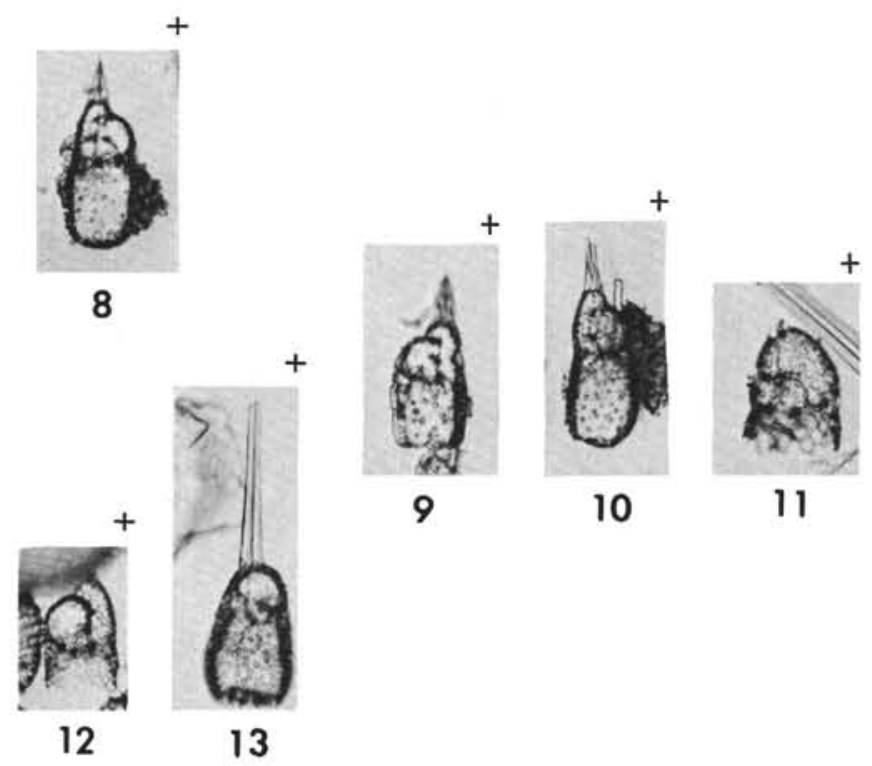

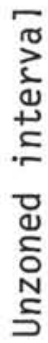




\section{PLATE 22}

Figure $1 \quad$ Polysolenia sp.

94-12-1 (42-44 cm), Sl. A, T19/2 (230×)

Figure 2 Collosphaerid gen. et. sp. indet. 94-12 (CC), Sl. 1, J21/3 (230×)

Figure 3 Saturnalin with spiny ring 86-8-4 (1-2 cm), Cse., T30/3 (180×)

Figure $4 \quad$ Amphisphaera minor (Clark and Campbell) 94-22-4 (42-44 cm), Cse. 1, X29/4 (165×)

Figure $5 \quad$ Astrosphaerin sp. A

86-8 (CC), Cse., V38/0 (165×)

Figure $6 \quad$ Astrosphaerin sp. cf. sp. A 96-3 (CC), Cse. A, V32/3 (180×)

Figure $7 \quad$ Astrosphaerin sp. B 96-3-5 (42-44 cm), Cse. F, S23/0 (165×)

Figure $8 \quad$ Astrosphaerin sp. C 96-3-5 (42-44 cm), Cse. F, H31/1 (165 × )

Figure 9 Astrosphaerin sp. D 96-3-6 (42-44 cm), Cse. 1, W17/2 (165×)

Figures 10,11, Terminal spathilla on astrosphaerin spine 86-8 (CC), Cse., R27/0 (255×)

10. $255 \times$

11. $350 \times$

Figure 12 Lattice-shell fragment, possibly from astrosphaerin sp. D, E or F.

94-30-2 (114-116 cm), Cse. 1, Q17/3 (165X) 
PLATE 22

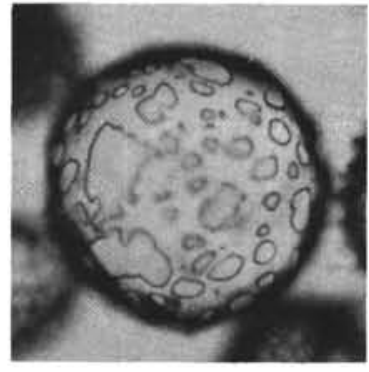

1

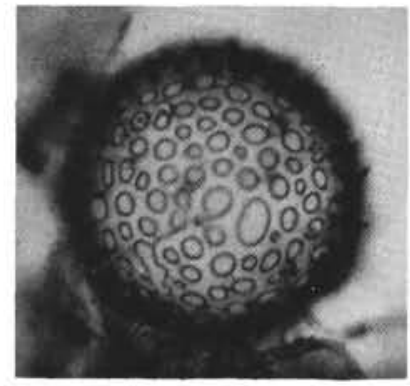

2

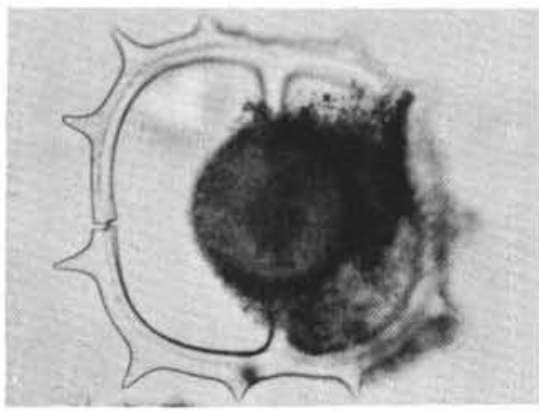

3

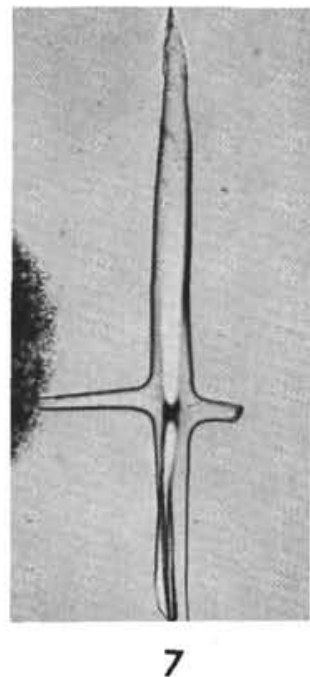

6
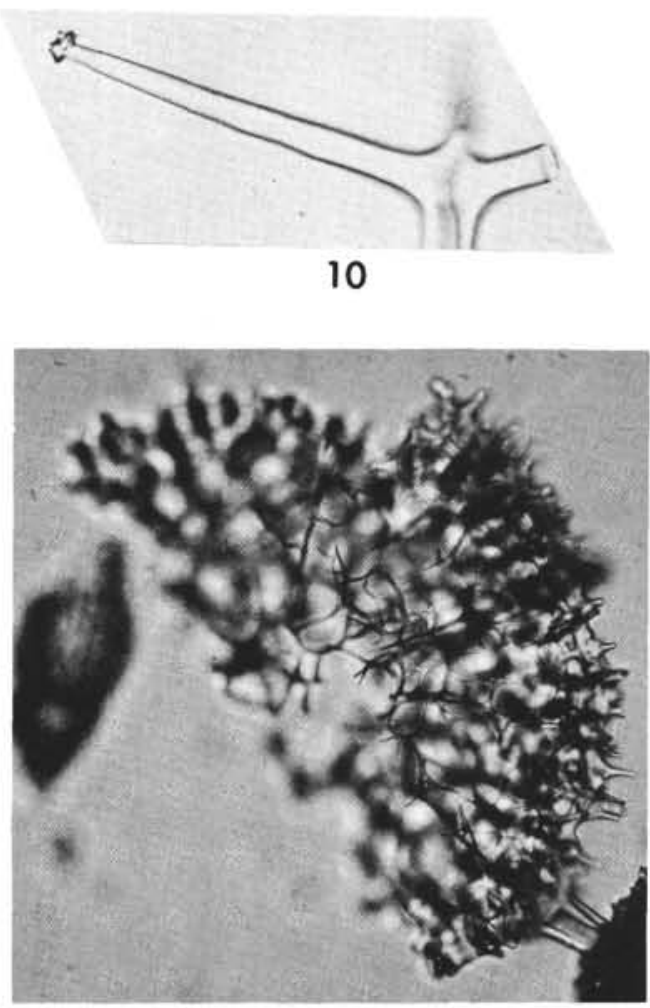

12

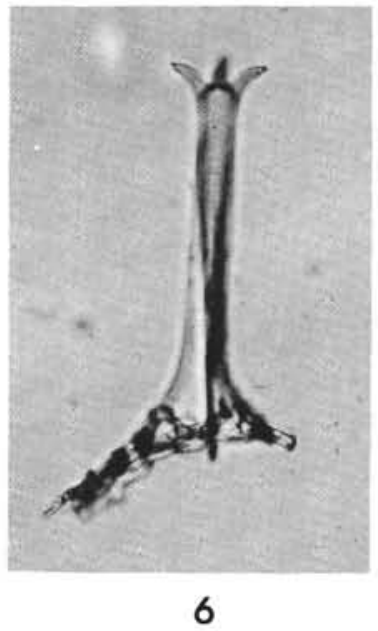

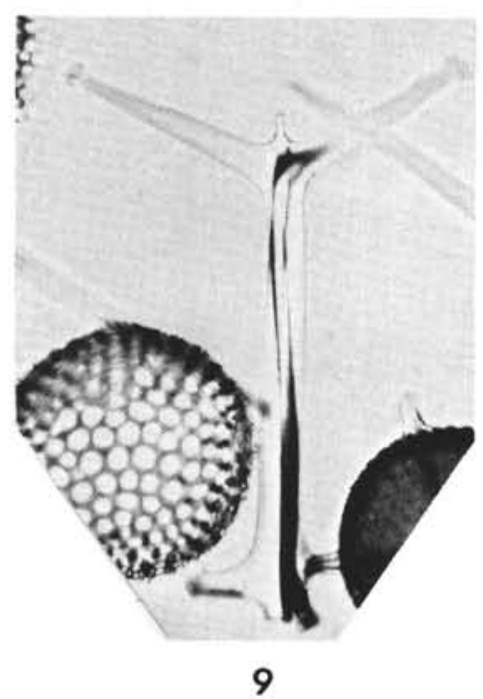


PLATE 23

Figure $1 \quad$ Astrosphaerin sp. E

86-8 (CC), Cse., B26/1 (165X)

Figure 2 Astrosphaerin sp. F

86-8 (CC) Cse., R6/1 (180×)

Figure 3 Axoprunum pierinae (Clark and Campbell) group 94-22-4 (42-44 cm), Cse. 1, L22/0 (165×)

Figures 4, $5 \quad$ Carposphaera subbotinae (Borinsenko)

4. 86-8 (CC), Cse., J12/2 (165×)

5. $94-30-2(44-46 \mathrm{~cm})$, Cse. $1, \mathrm{E} 47 / 3(165 \times)$

Figure $6 \quad$ Cenosphaera sp. A

94-30-2 (114-116 cm), Ph. 2, X12/1 (255X)

Figures 7, 8 Diploplegma somphum Sanfilippo and Riedel, n. sp. 7. Holotype, 96-3-6 (42-44 cm), Cse. 1, R42/1 $(180 \times)$

8. 86-8 (CC), Cse., J12/4 (165×)

Figures 9-12 Entapium chaenapium Sanfilippo and Riedel, n. sp.

9. Holotype, 94-28-2 (42-44 cm), Ph. 1, 024/1 $(180 \times)$

10-12: Broken specimens showing open medullary shell, displaced peripherally in fig. 11.

10. $94-26-4(43-45 \mathrm{~cm})$, Cse. $2, \mathrm{E} 19 / 3(255 \times)$

11. $94-26-4(43-45 \mathrm{~cm})$, Cse. $2, \mathrm{H} 23 / 1(255 \times)$

12. $94-27$ (CC), S1. 1, M24/1 $(255 \times)$ 
PLATE 23
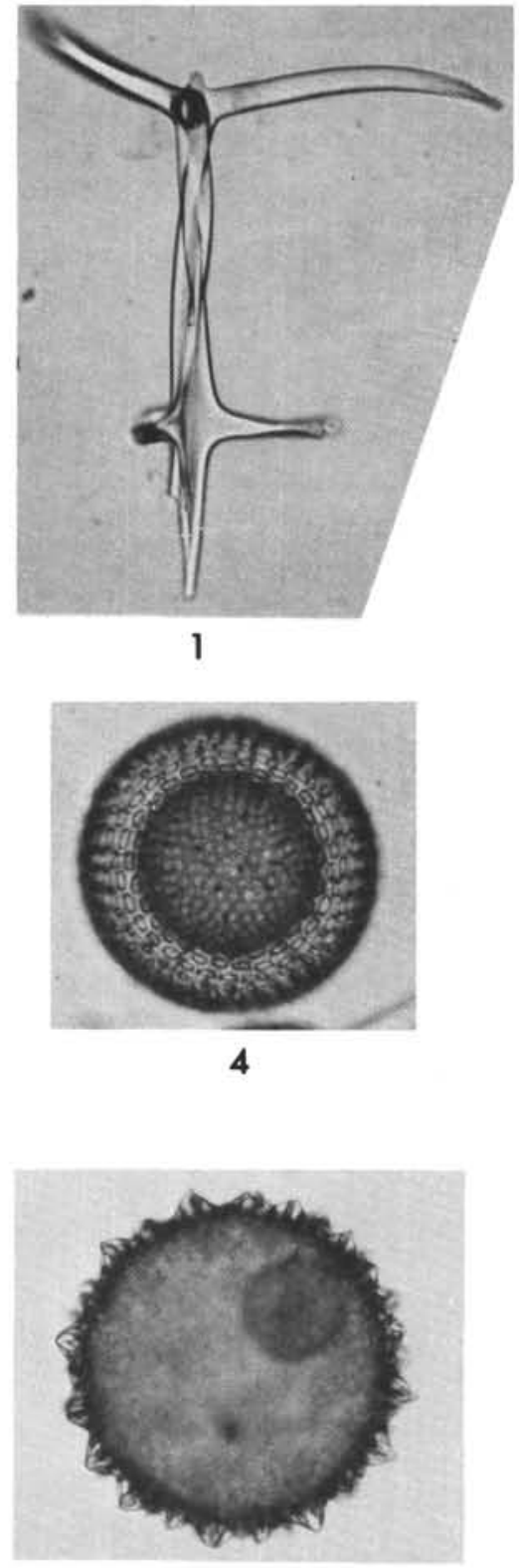

7

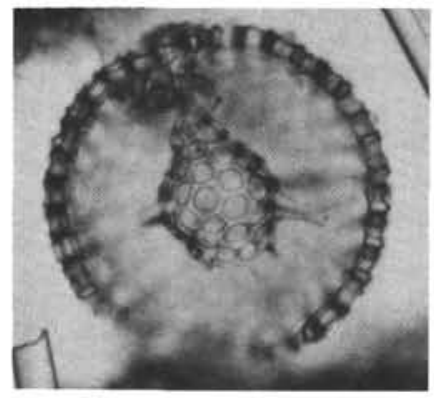

10
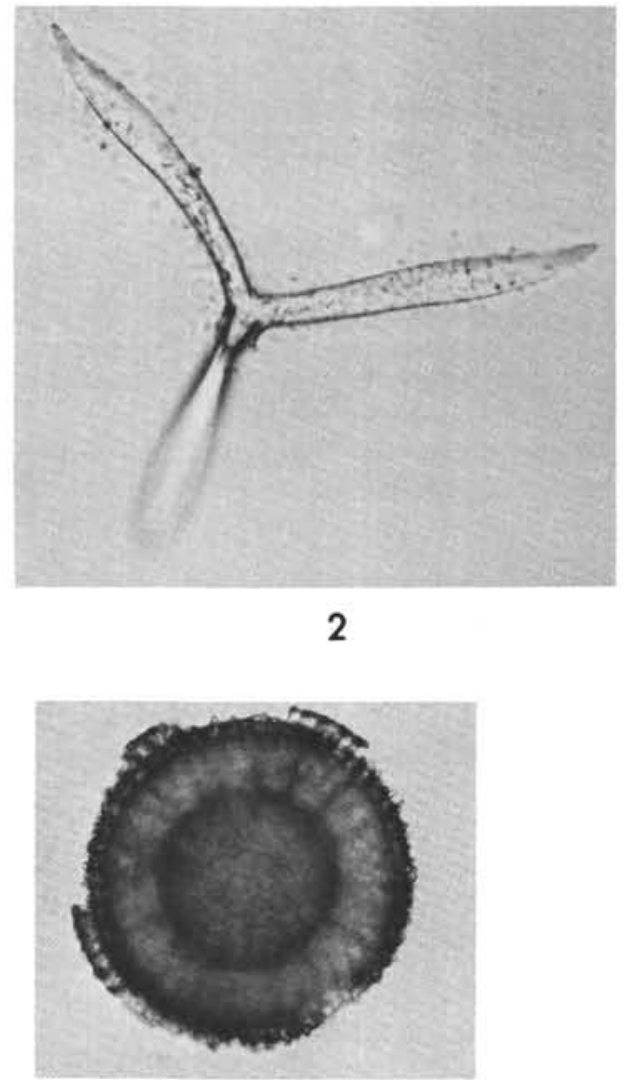

5
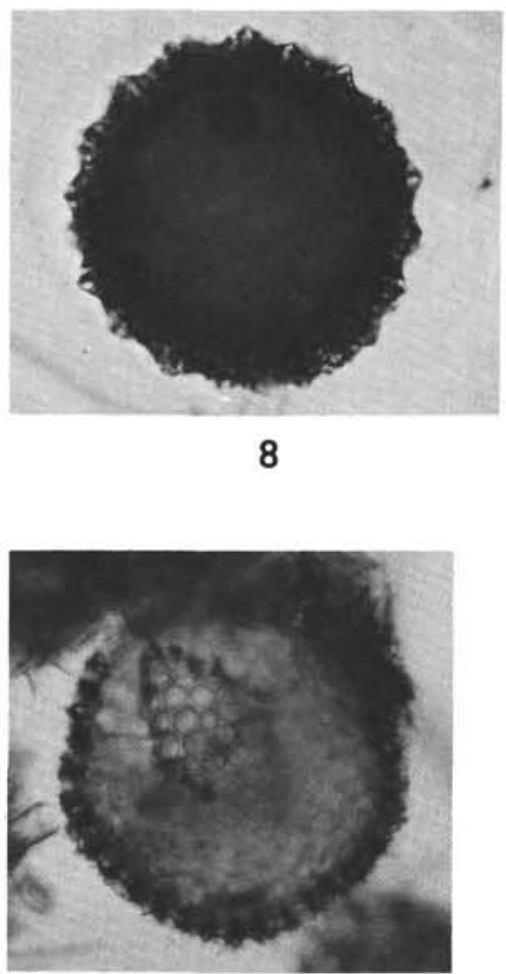

11

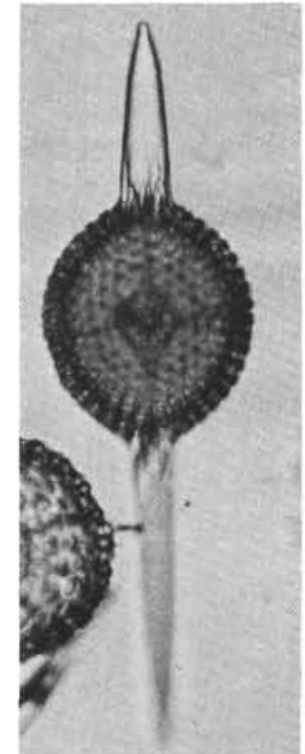

3
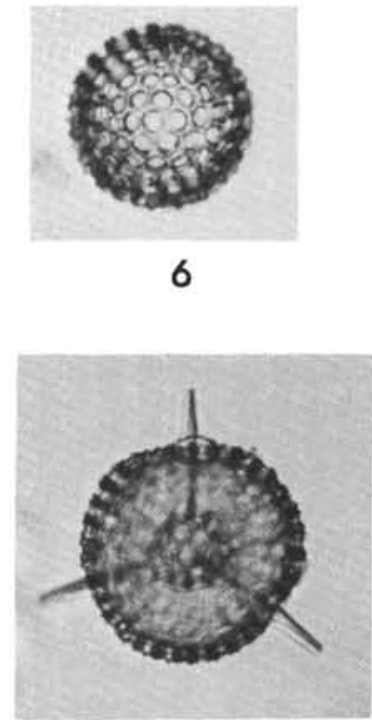

9

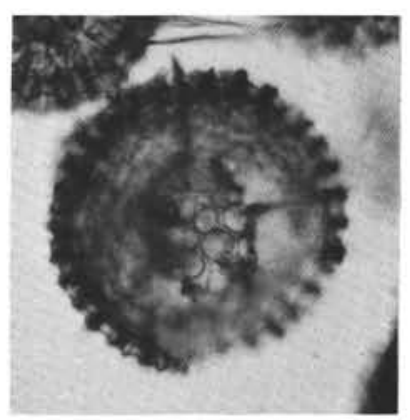

12 
PLATE 24

Figures 1-3 Entapium regulare Sanfilippo and Riedel, n. sp. 1,2 . Holotype, focused on different planes. 94-22-4 (42-44 cm), Cse. 1, H25/1 (165×)

3. $96-3-6(42-44 \mathrm{~cm})$, Cse. 2 , X42/0 $(180 \times)$

Figure 4 Hexacontium palaeocenicum Sanfilippo and Riedel, n. sp.

Holotype, 86-8-3 (44-46 cm), Cse., J18/2 (165×)

Figure $5 \quad$ Hexalonche (?) sp. A

86-8-4 (46-48 cm), Cse. 5, L12/0 (255×)

Figures 6, 7 Lithapium anoectum Riedel and Sanfilippo

6. $95-7-1(43-45 \mathrm{~cm}), \mathrm{Sl} .1, \mathrm{R} 50 / 3(255 \times)$

7. $95-7-1(43-45 \mathrm{~cm})$, Slide " $<124 \mu \mathrm{A}$ ", V43/0 $(230 \times)$

Figures 8, 9 Lithapium plegmacantha Riedel and Sanfilippo

8. 94-25-3 (113-115 cm), Cse., W24/3 (255 X)

9. $94-23-2$ (42-44 cm), Cse. 1, P16/0 (230×)

Figures 10, 11 Lithomespilus mendosa (Krasheninnikov)

10. 86-8-3 $(44-46 \mathrm{~cm})$, Cse., P35/3 $(255 \times)$

11. 86-8-3 (44-46 cm), Cse., H18/2 (255 $\times)$ 
PLATE 24
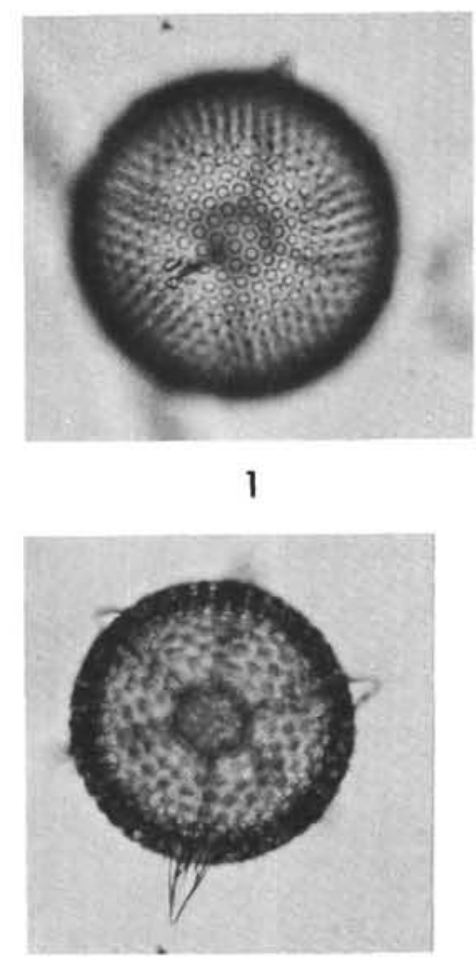

4

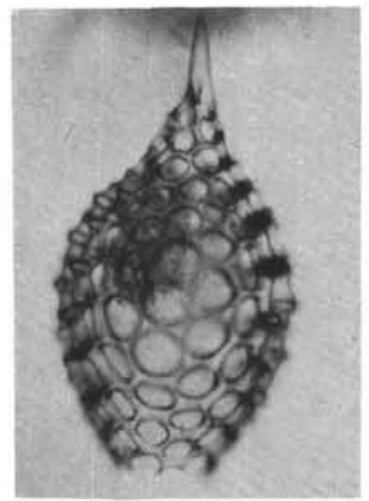

6

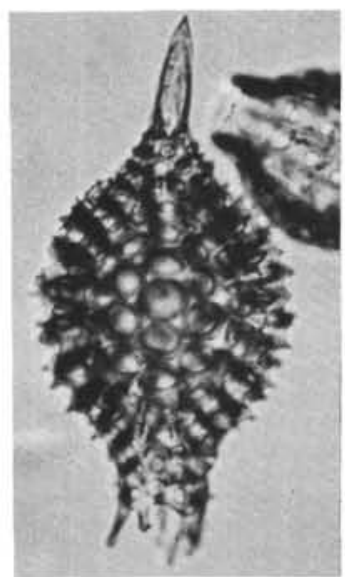

7
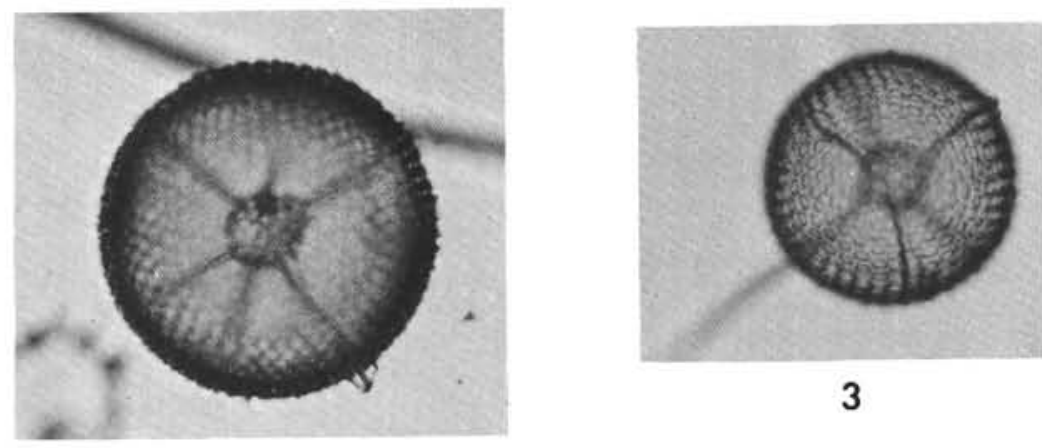

3

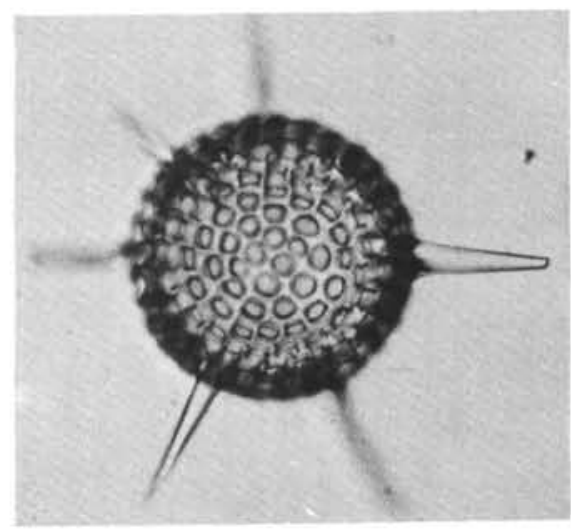

5

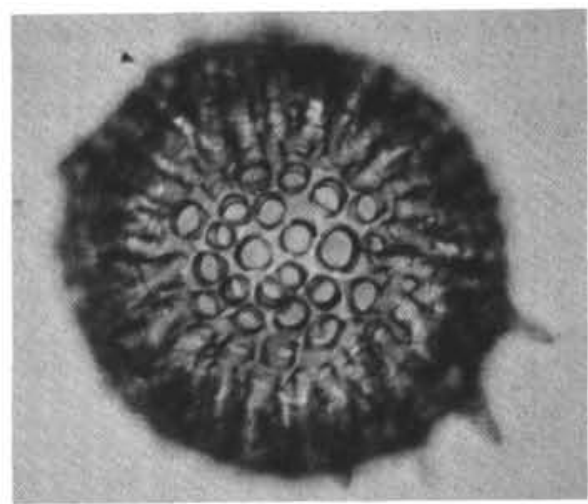

10

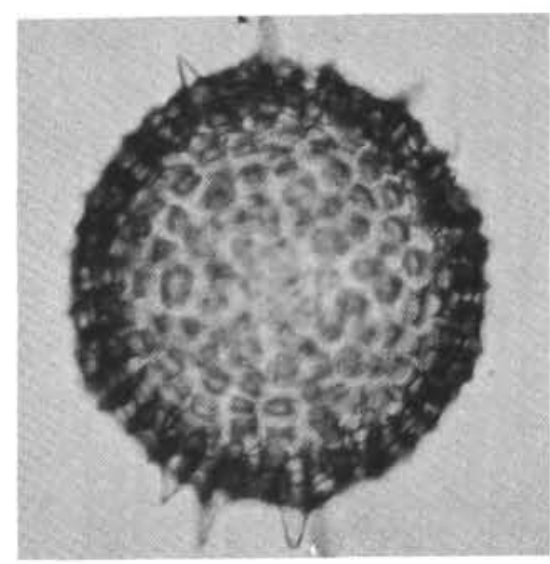

11 


\section{PLATE 25}

Figures 1, 2 Spongatractus balbis Sanfilippo and Riedel, n. sp. 1. Holotype, 95-8-2 (42-44 cm), Cse. 1, J15/0 $(165 \times)$

2. 94-30-2 (114-116 cm), Cse. $1, \mathrm{Q} 48 / 2(165 \times)$

Figure $3 \quad$ Spongatractus pachystylus (Ehrenberg) 94-22-4 (42-44 cm), Cse. 1, D33/3 (165×)

Figure $4 \quad$ Stylosphaera coronata coronata Ehrenberg 95-7 (CC), Sl. 1, M37/1 (255×)

Figures 5, 6 Stylosphaera coronata laevis Ehrenberg 5. $94-20-2(39-41 \mathrm{~cm})$, Sl. $2, \mathrm{H} 39 / 4(255 \times)$

6. $94-17-1(36-38 \mathrm{~cm})$, Slide " $<124 \mu \mathrm{A}$ " K21/1 $(230 \times)$

Figures 7, 8 Stylosphaera coronata sabaca Sanfilippo and Riedel, n. sp.

7. Holotype, 94-26-2 (43-45 cm), Ph. 1, K18/2 $(255 \times)$

8. $94-28-5(43-45 \mathrm{~cm})$, Sl. $1, \mathrm{C} 46 / 4(255 \times)$

Figures 9, 10 Stylosphaera goruna Sanfilippo and Riedel, n. sp. 9. 86-7 (CC), Sl. 2, U13/0 (180X)

10. Holotype, 96-3-4 (42-44 cm), Ph. 2, X46/0 $(255 \times)$

Figures 11, 12 Actinommids genn. et spp. indet

11. 96-3-4 (42-44 cm), Ph. 2, Y18/4 (255X)

12. $86-7$ (CC), Sl. A, T27/0 (230X)

Figures 13, 14 Thecosphaera larnacium Sanfilippo and Riedel, $\mathrm{n}$. sp.

13. Holotype, $96-4$ (CC), Sl. 1A, S19/0 (180×)

14. $86-8-3(44-46 \mathrm{~cm})$, Cse., M10/0 $(255 \times)$

Figure 15 Thecosphaerella sp. cf. T. agdaraensis (Mamedov) 95-8 (CC), Cse. A, T27/3 (165×) 
PLATE 25
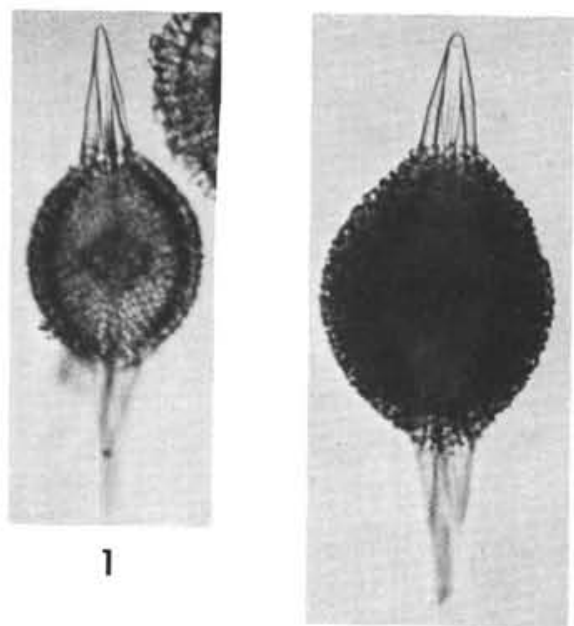

3

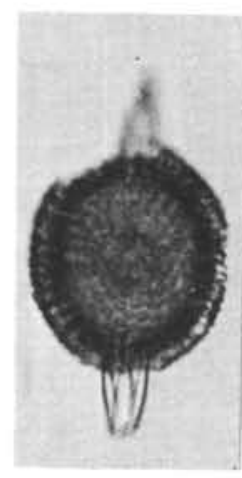

2

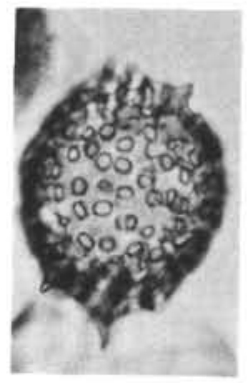

12

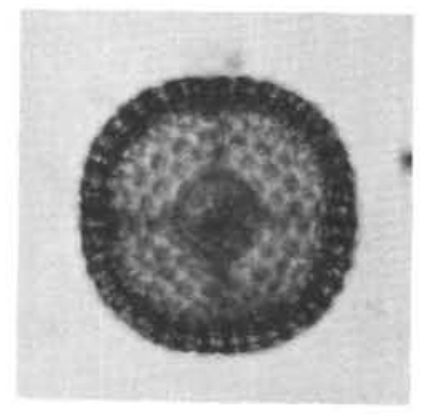

13

8
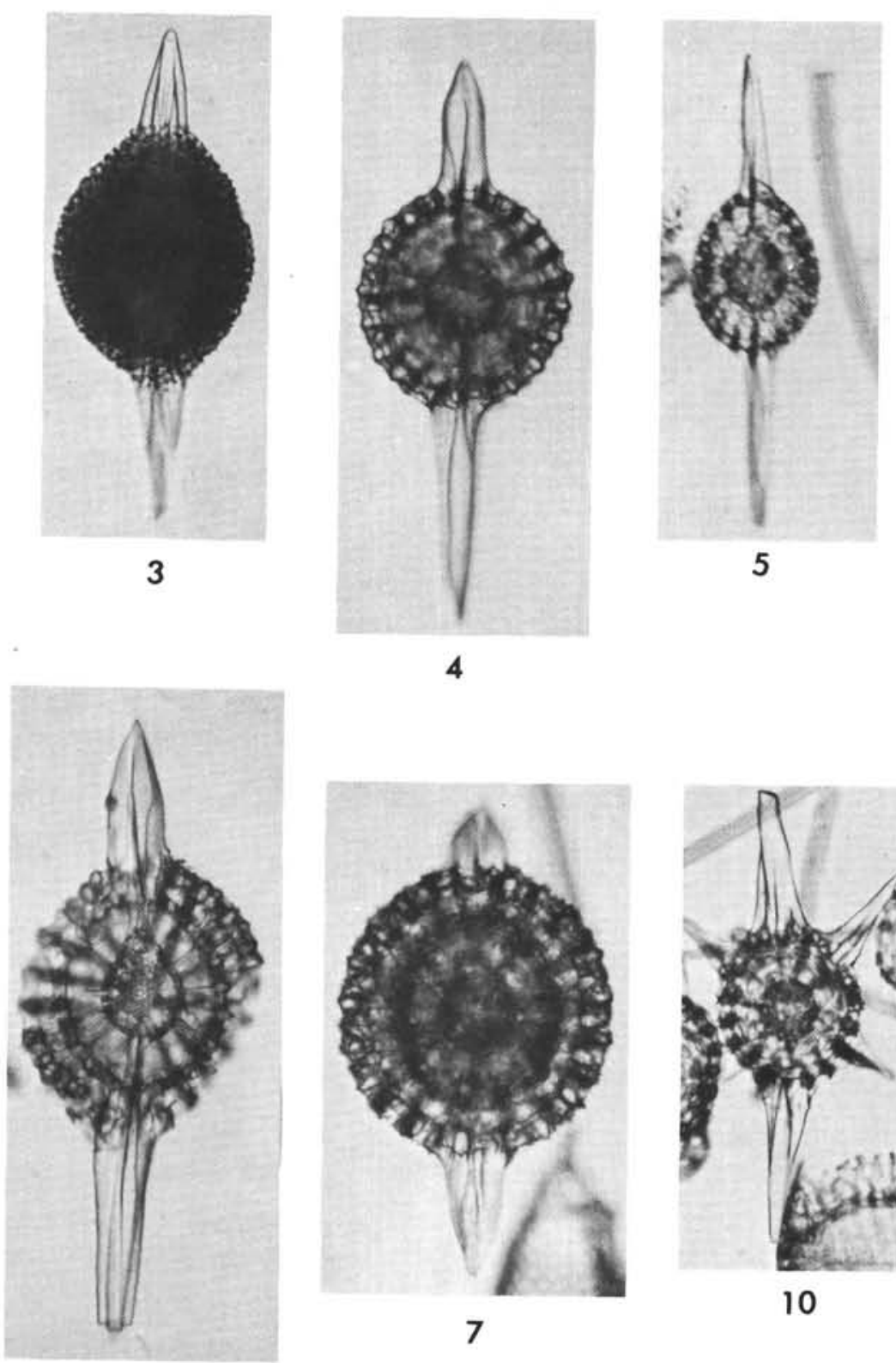
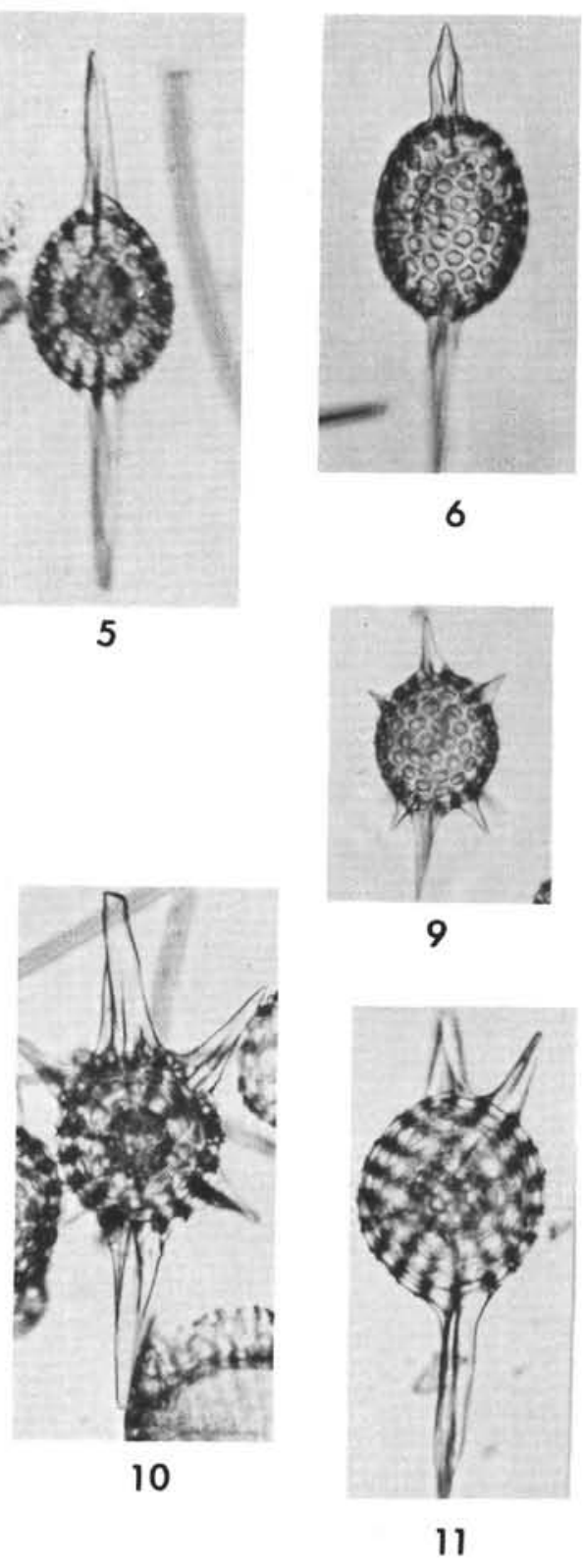

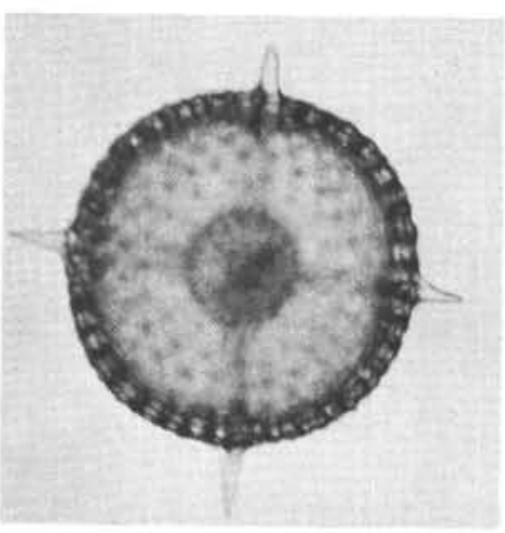

14

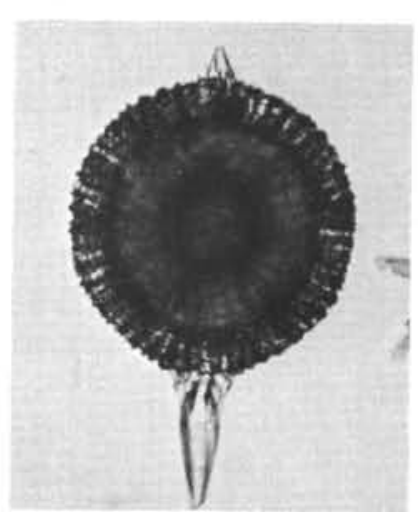

15 


\section{PLATE 26}

Figure 1 Thecosphaerella glebulenta Sanfilippo and Riedel, $\mathrm{n}$. sp.

Holotype, 94-30-2 (114-116 cm), Cse. 1, S50/0 $(255 \times)$

Figure 2 Thecosphaerella ptomatus Sanfilippo and Riedel, $\mathrm{n}$. sp.

Holotype, 96-3-5 (42-44 cm), Cse. G, W8/3 (165×)

Figure 3 Thecosphaerella rotunda (Borisenko) 95-8-4 (42-44 cm), Cse. 1, W22/1 (165×)

Figures 4, 5 Lithelius foremanae Sanfilippo and Riedel, n. sp.

4. Holotype, 86-7 (CC), Sl. 2, R38/1 (180×)

5. $94-30-1(80-82 \mathrm{~cm})$, Cse. 2 , P28/0 (180 $\times)$

Figures 6,7 Lithelius hexaxyphophorus (Clark and Campbell) 6. $94-22-2(42-44 \mathrm{~cm}), \mathrm{Sl} .1, \mathrm{~L} 20 / 1(255 \times)$

7. $94-24-2(42-44 \mathrm{~cm})$, Sl. 2 , Q14/1 $(255 \times)$

Figure $8 \quad$ Actinommid gen. et. sp. indet.

94-30-2 (114-116 cm), Cse. 1, X38/3 (255×)

Figure 9 Astrophacus linckiaformis (Clark and Campbell) 95-7-4 (43-45 cm), Cse. 1, L35/2 (165×)

Figures 10-12 Heliostylus $\mathrm{sp}(\mathrm{p})$.

10. 96-3-6 (42-44 cm), Cse. 2 , Y $41 / 2(180 \times)$

11. 96-3-6 (42-44 cm), Cse. 2 , E20/2 (180X)

12. 96-3-6 (42-44 cm), Cse. 2, Q42/0 (180X) 
PLATE 26

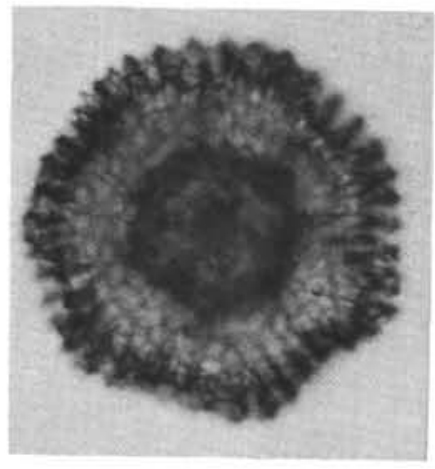

1

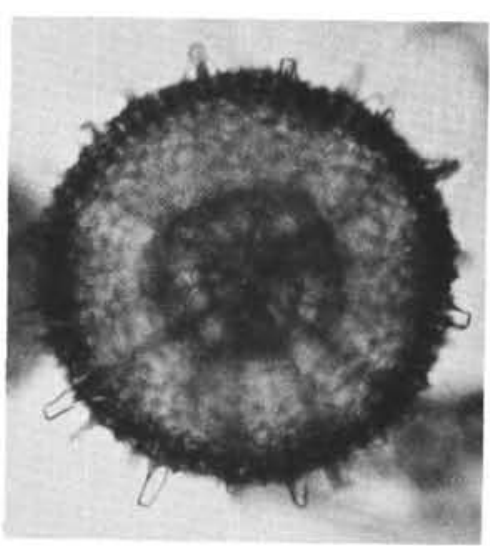

6

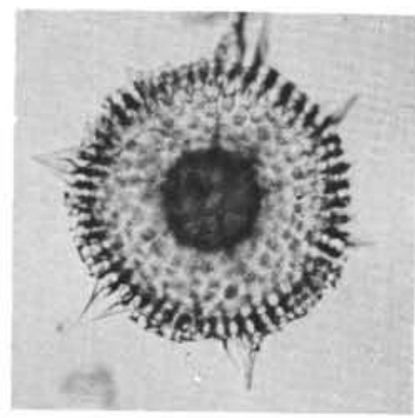

9

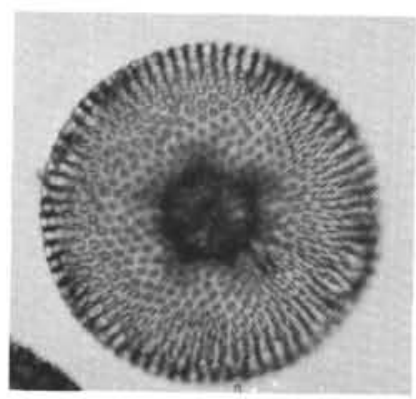

11

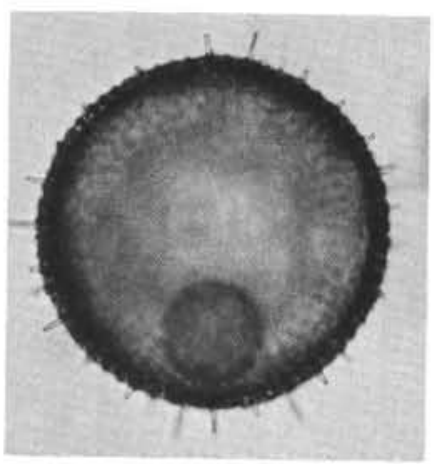

2

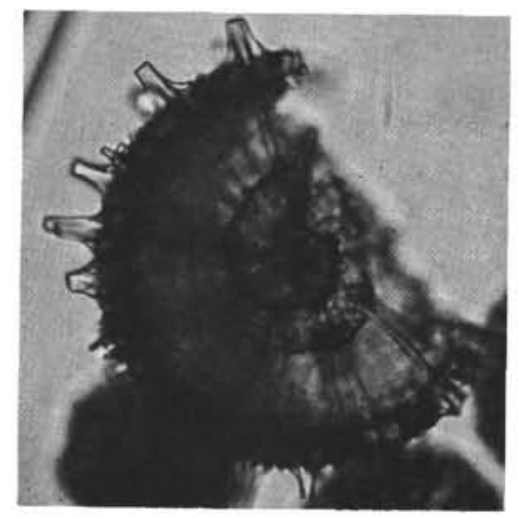

7

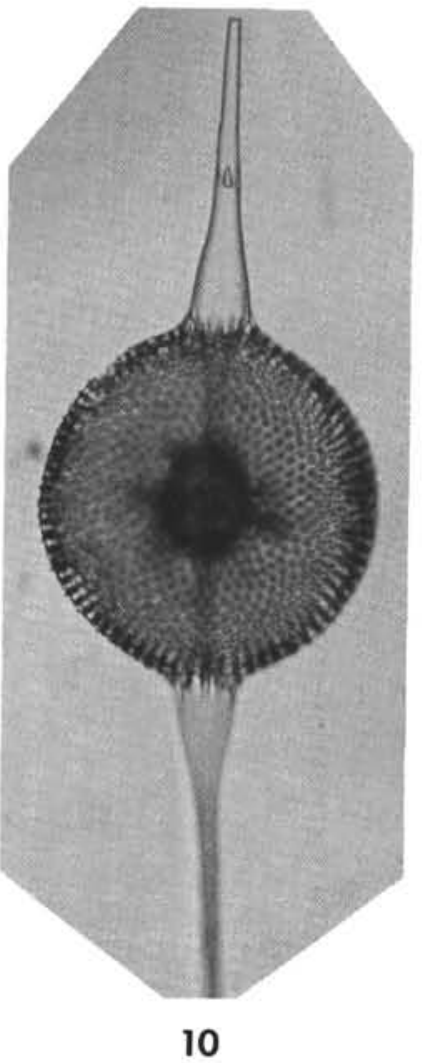

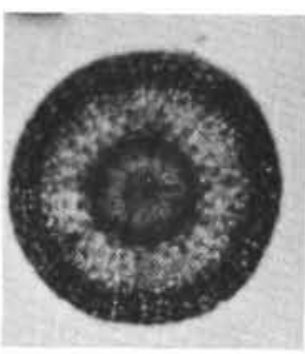

3
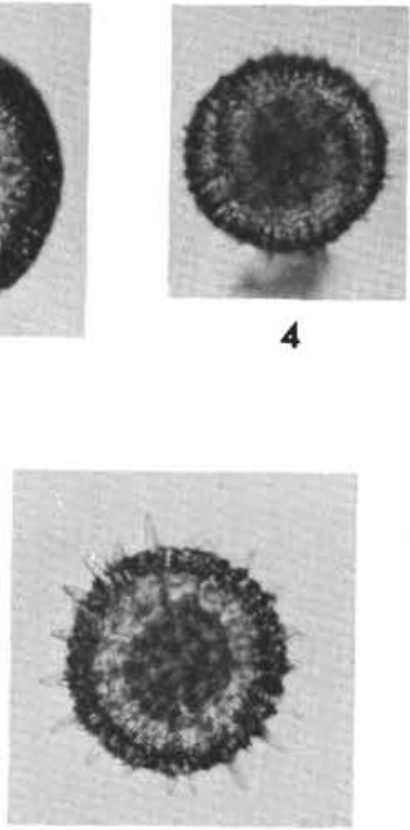

5

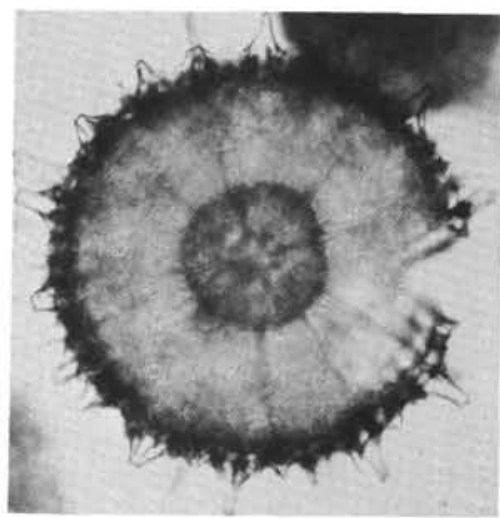

8

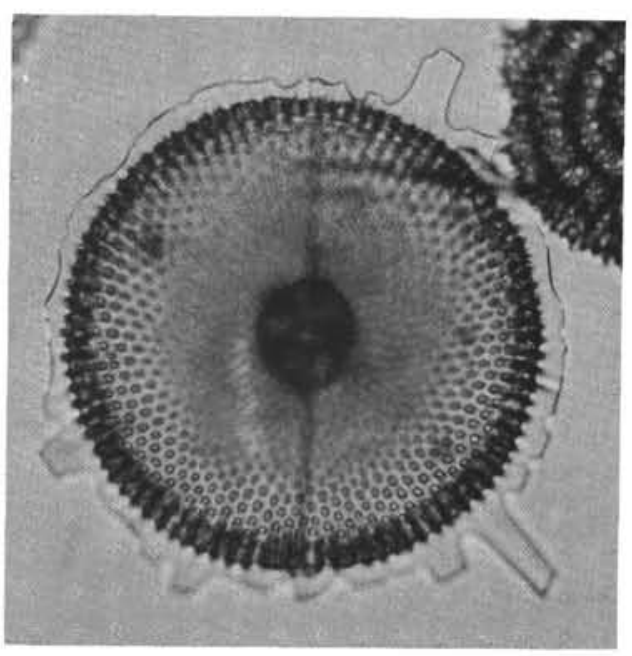

12 


\section{PLATE 27}

Figure $1 \quad$ Heliostylus $\mathrm{sp}(\mathrm{p})$

94-23-2 (112-114 cm), Cse. 1, C42/0 (180×)

Figures 2-5 Periphaena decora Ehrenberg

2. 94-20-4 (42-44 cm), Cse. 1, M37/4 (180×)

3. 95-7-4 (43-45 cm), Cse. 1 , K38/4 $(165 \times)$

4. $94-20-4(42-44 \mathrm{~cm})$, Cse. $1, \mathrm{Y} 17 / 0(180 \times)$

5. $94-21-2(42-44 \mathrm{~cm})$, Cse. $1, \mathrm{C} 31 / 3(180 \times)$

Figures 6, 7 Periphaena delta Sanfilippo and Riedel, n. sp.

6. Holotype, 94-23-2 (112-114 cm), Cse. 1, U33/0 $(180 \times)$

7. $94-23-2(112-114 \mathrm{~cm})$, Cse. 1 , U23/1 (180×)

Figures 8, 9 Periphaena heliasteriscus (Clark and Campbell)

8. 95-7-4 (43-45 cm), Cse. 1, 033/3 (165X)

9. 94-20-4 (42-44 cm), Cse. 1, R27/0 (180×)

Figure 10 Spongodiscid gen. et sp. indet.

86-8-3 (44-46 cm), Cse., P26/0 (165×)

Figure 11 Spongodiscus americanus Kozlova

Specimen with large hollow cone penetrating from periphery toward center. 96-3 (CC), Cse. 1, G36/4 $(165 \times)$ 
PLATE 27
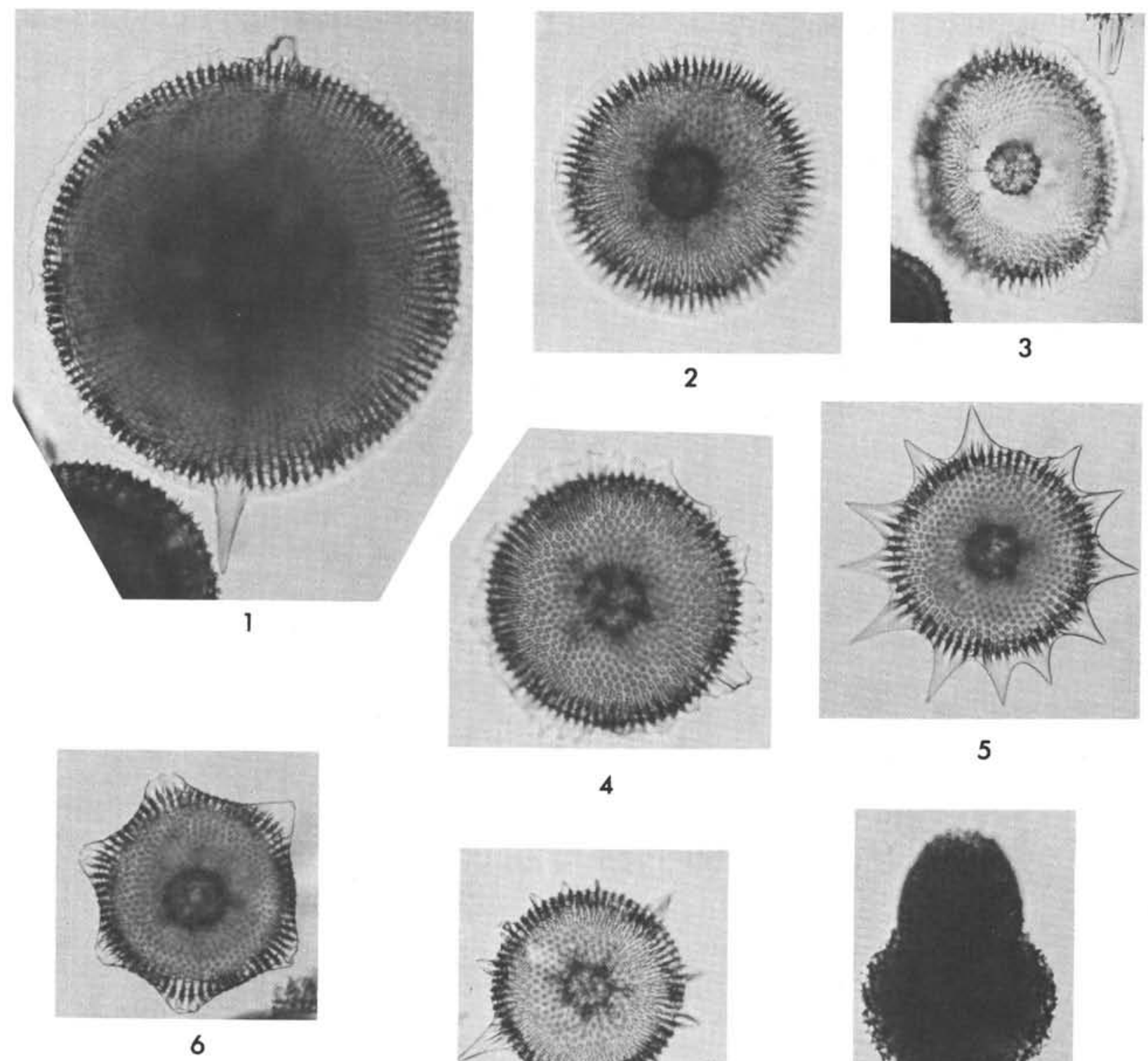

2

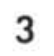

3

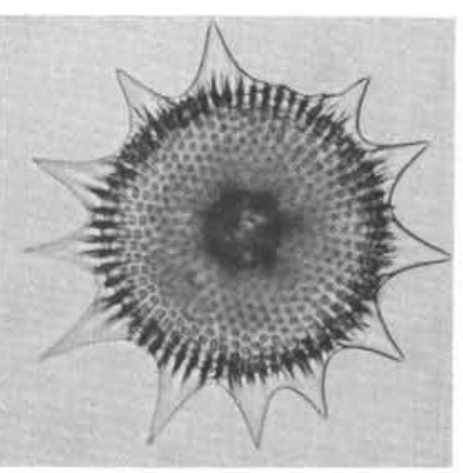

5

4
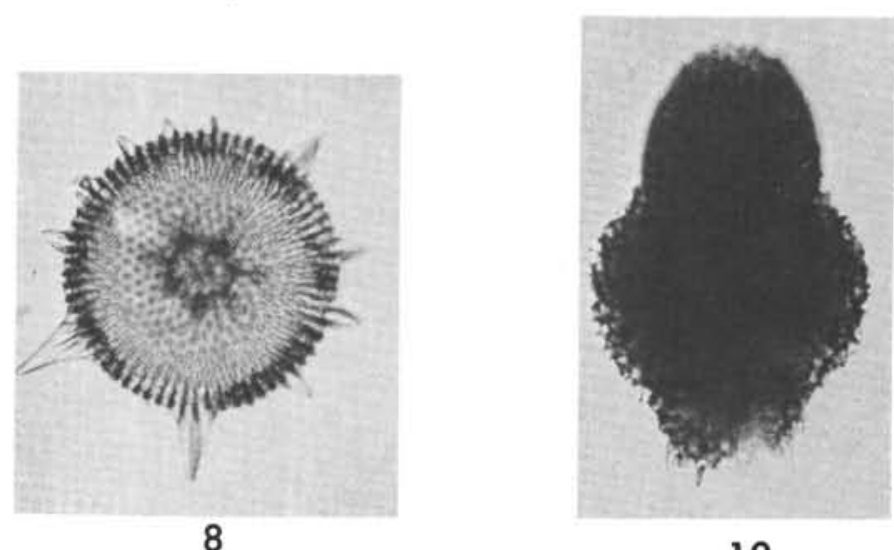

10

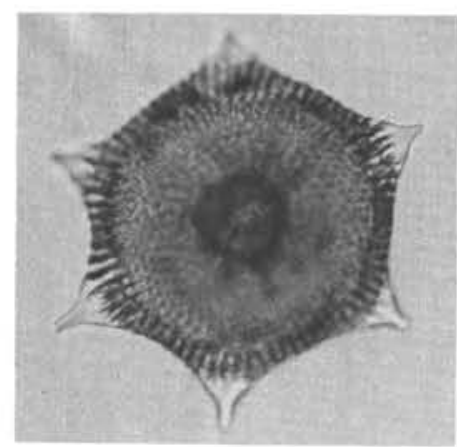

7

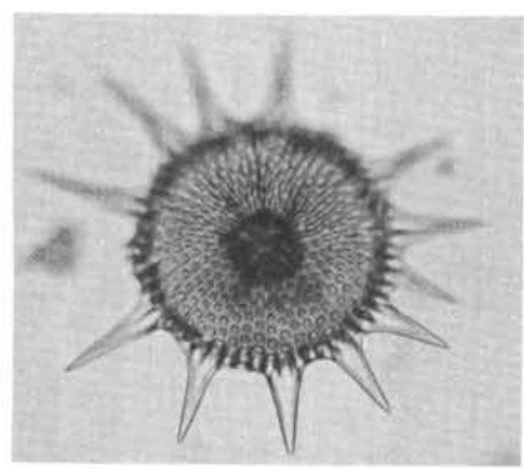

9

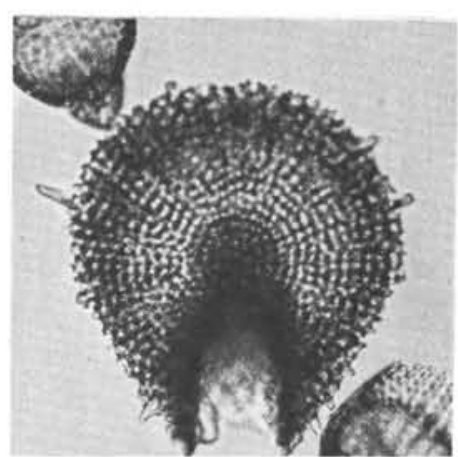

11 
PLATE 28

Figure $1 \quad$ Amphicraspedum murrayanum Haeckel 96-3-5 (42-44 cm), Cse. G, U14/4 (165×)

Figure 2 Amphicraspedum sp. cf. A. murrayanum Haeckel 96-4 (CC), Cse. 2, Y38/4 (165×)

Figures 3, 4 Amphicraspedum prolixum Sanfilippo and Riedel, $\mathrm{n}$. sp.

3. $94-22-4(42-44 \mathrm{~cm})$, Cse. 1, Y15/0 (95 $\times)$

4. Holotype, 94-28-2 (42-44 cm), Cse. 2, U32/2 $(165 \times)$

Figure $5 \quad$ Amphicraspedum prolixum Sanfilippo and Riedel group

96-3-5 (42-44 cm), Cse. G, V33/0 (165×)

Figures 6-8 Amphymenium splendiarmatum Clark and Campbell

6. $94-28-5(43-45 \mathrm{~cm})$, Sl. $1, \mathrm{~V} 10 / 0(230 \times)$

7. $94-20-2(39-41 \mathrm{~cm})$, Ph. $1, \mathrm{~S} 16 / 0(230 \times)$

8. $94-22-4(42-44 \mathrm{~cm})$, Sl. $2, \mathrm{M} 32 / 2(230 \times)$

Figure $9 \quad$ Spongodiscus americanus Kozlova

94-26-3 (43-45 cm), Cse. 1, T22/2 (165×)

Figures 10, 11 Spongodiscus cruciferus Clark and Campbell

10. $96-3-5(42-44 \mathrm{~cm})$, Cse. G, 030/0 (165 $\times)$

11. 96-4 (CC), Cse. $2, \mathrm{X} 46 / 4$ (165-211) 
PLATE 28
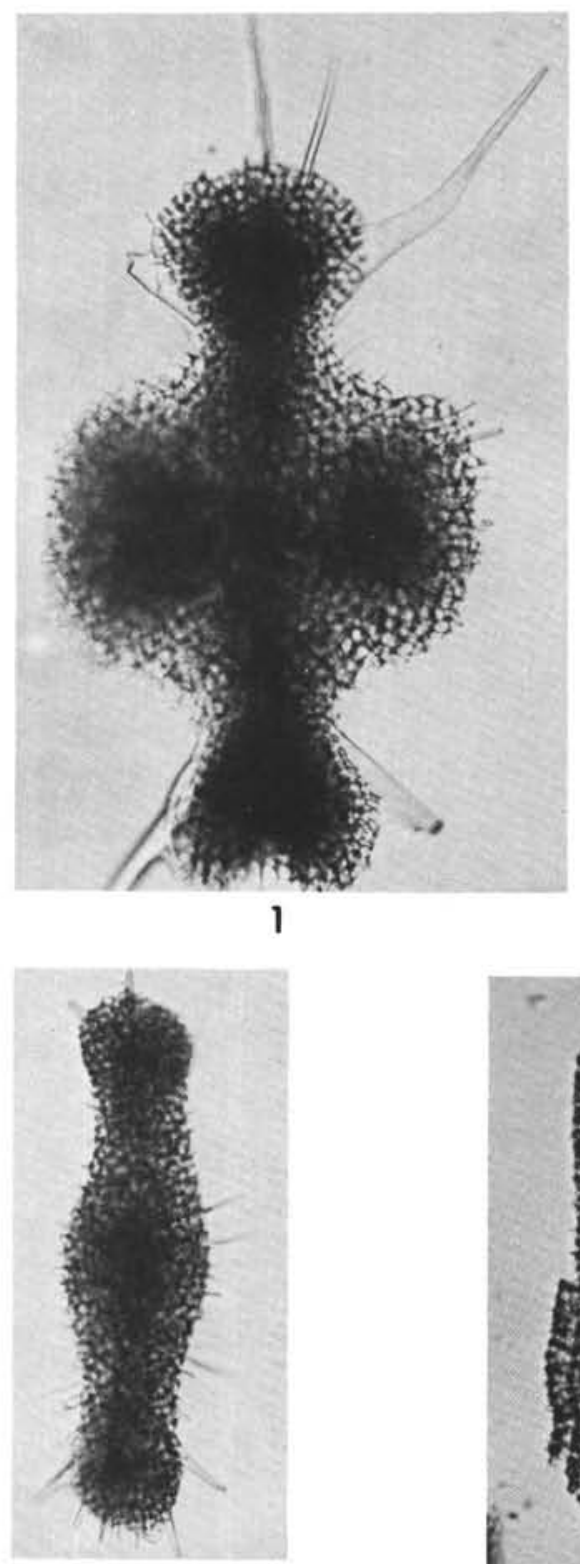

5

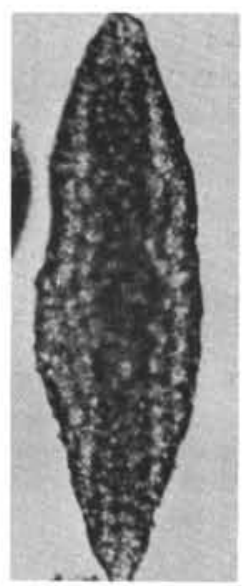

7

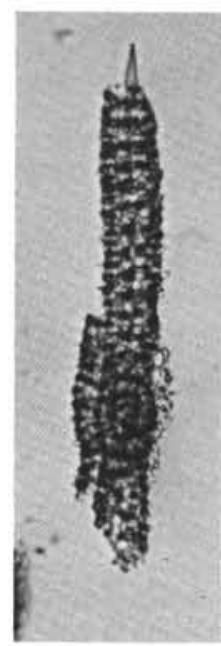

6

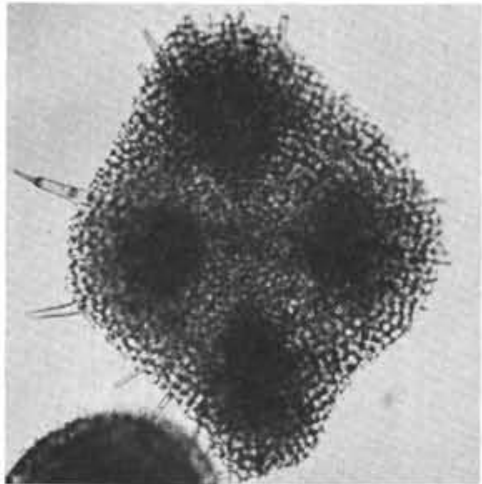

10

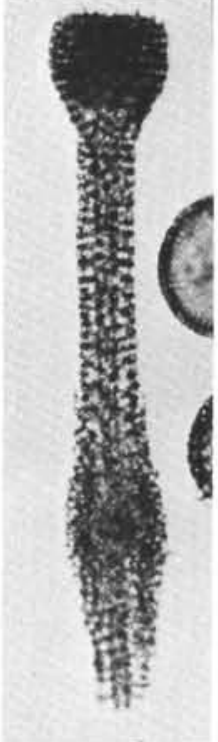

3

2
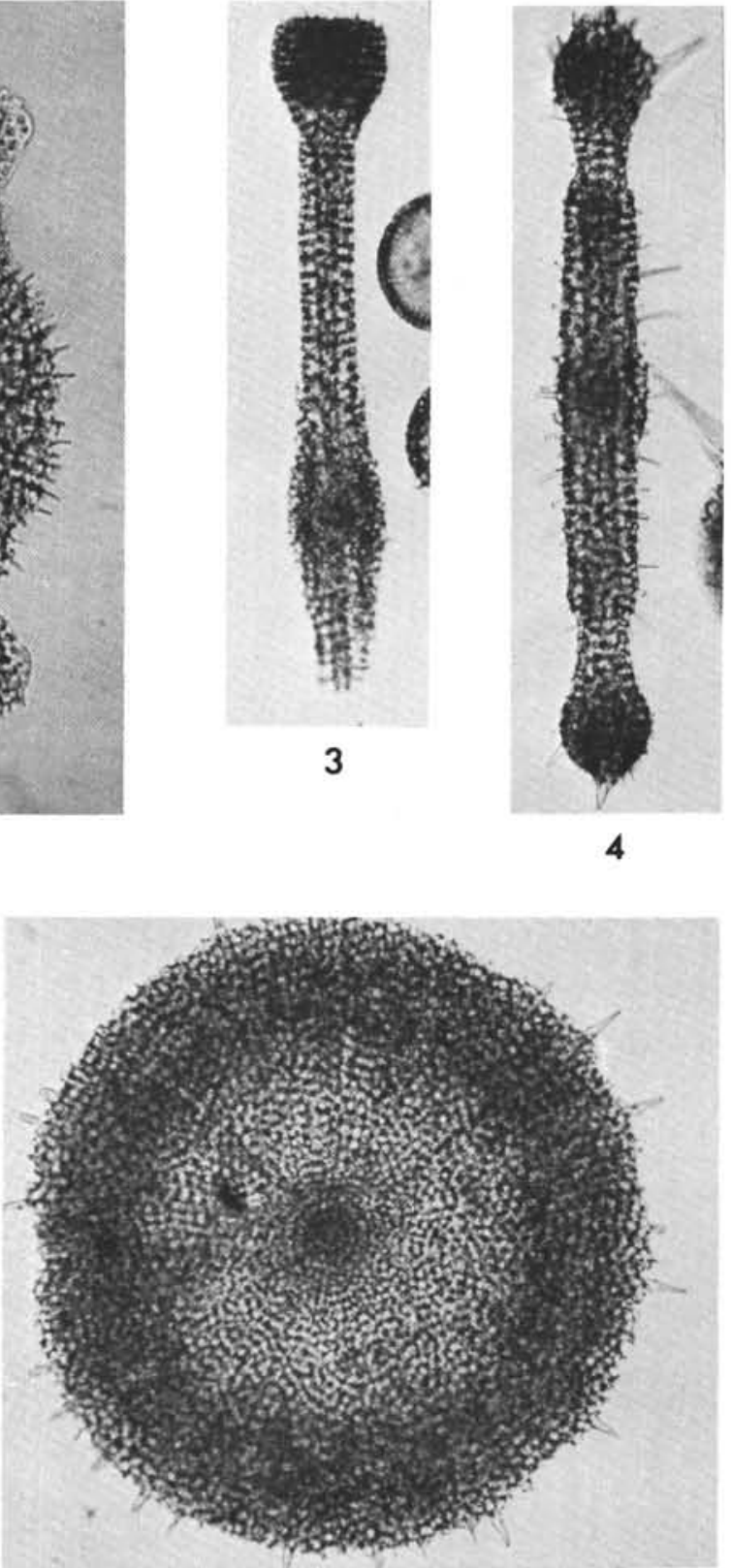

9

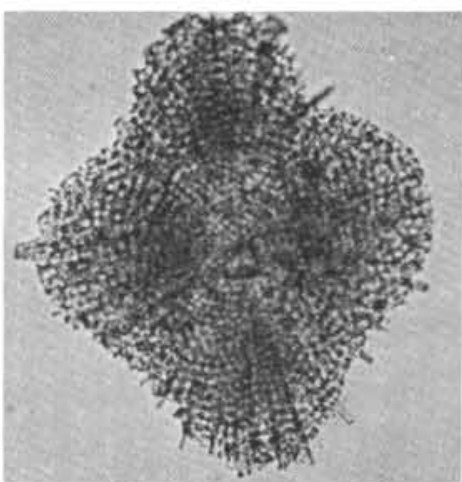

11 


\section{PLATE 29}

Figure $1 \quad$ Spongodiscus sp.

86-8 (CC), Cse. A, T18/3 (180×)

Figure 2 Spongodiscus phrix Sanfilippo and Riedel, n. sp. Holotype, 94-26-3 (43-45 cm), Cse. 1, U27/0 $(165 \times)$

Figures 3, $4 \quad$ Spongodiscus pulcher Clark and Campbell

3. 95-8-1 (44-46 cm), Cse. C, Y14/0 (165×)

4. $95-8-2(42-44 \mathrm{~cm})$, Cse. $1, \mathrm{C} 25 / 0(165 \times)$

Figures 5, 6 Spongodiscus quartus quartus (Borisenko)

5. 96-3-5 (42-44 cm), Cse. F, S24/4 (165 $\times)$

6. $96-3-6(42-44 \mathrm{~cm})$, Cse. $1, \mathrm{~B} 19 / 4(165 \times)$

Figure 7

Spongodiscus quartus bosoculus Sanfilippo and Riedel, n. sp.

Holotype, 96-3-5 (42-44 cm), Cse. G. 029/3 (165×) 
PLATE 29

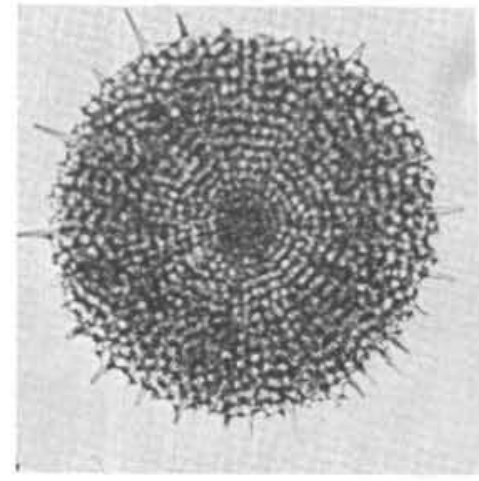

1

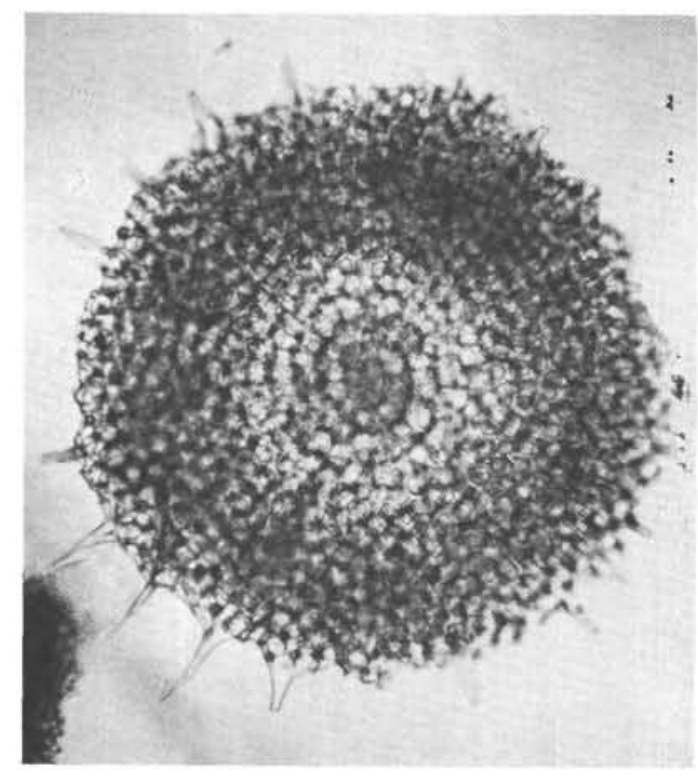

3

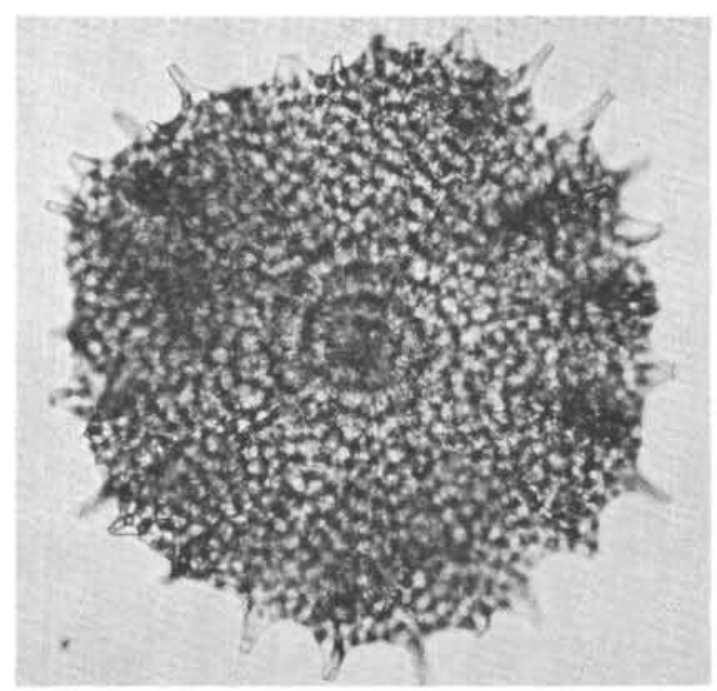

2

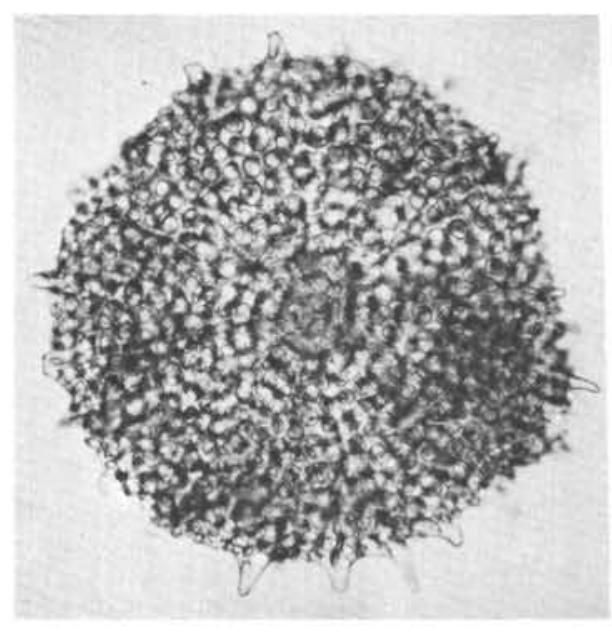

4

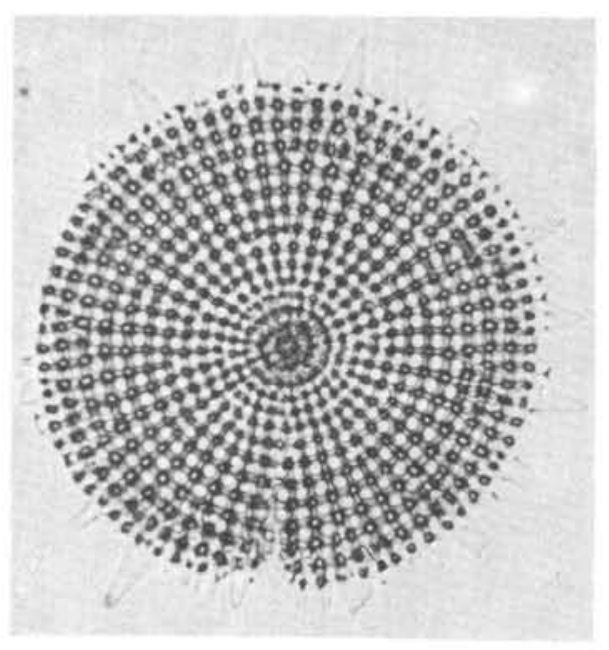

5

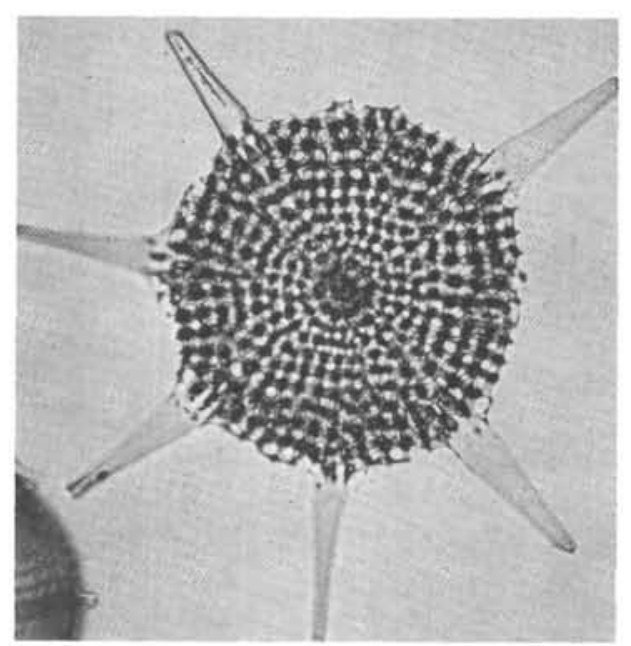

6

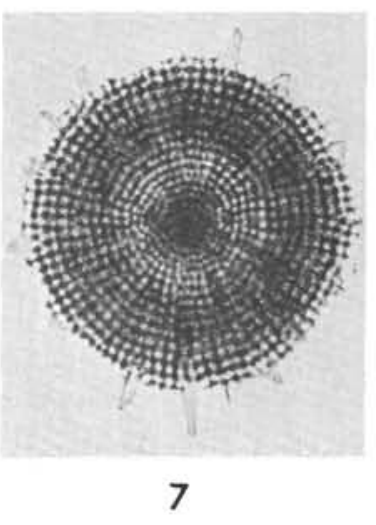


PLATE 30

Figures 1, 2 Spongodiscus rhabdostylus (Ehrenberg)

1. 94-22-1 (42-44 cm), Cse. C, Q34/0 $(165 \times)$

2. $95-8-2(42-44 \mathrm{~cm})$, Cse. $1, \mathrm{Q} 46 / 3(165 \times)$

Figures 3, $4 \quad$ Stylotrochus alveatus Sanfilippo and Riedel, n. sp.

3. 86-8 (CC), Cse. A, D41/1 (165X)

4. Holotype, 86-8 (CC), S1. A, L15/0 (165×)

Figures 5, 6 Stylotrochus charlestonensis (Clark and Campbell)? 5. $96-3-5(42-44 \mathrm{~cm})$, Cse. F, D23/0 $(180 \times)$

6. $94-21-2$ (42-44 cm), Cse. 1, U34/4 (180X)

Figures 7-10 Stylotrochus nitidus Sanfilippo and Riedel, n. sp. 7. Holotype, 96-3-5, $42-44 \mathrm{~cm}$, Cse. F, H37/2 $(180 \times)$

8. 96-3-6 (42-44 cm), Cse. 1, P32/1 (180×)

9. $96-3-6(42-44 \mathrm{~cm})$, Cse. $1, \mathrm{~F} 38 / 3(180 \times)$

10. $96-3-6(42-44 \mathrm{~cm})$, Cse. $2, \mathrm{H} 36 / 3(180 \mathrm{X})$ 
PLATE 30
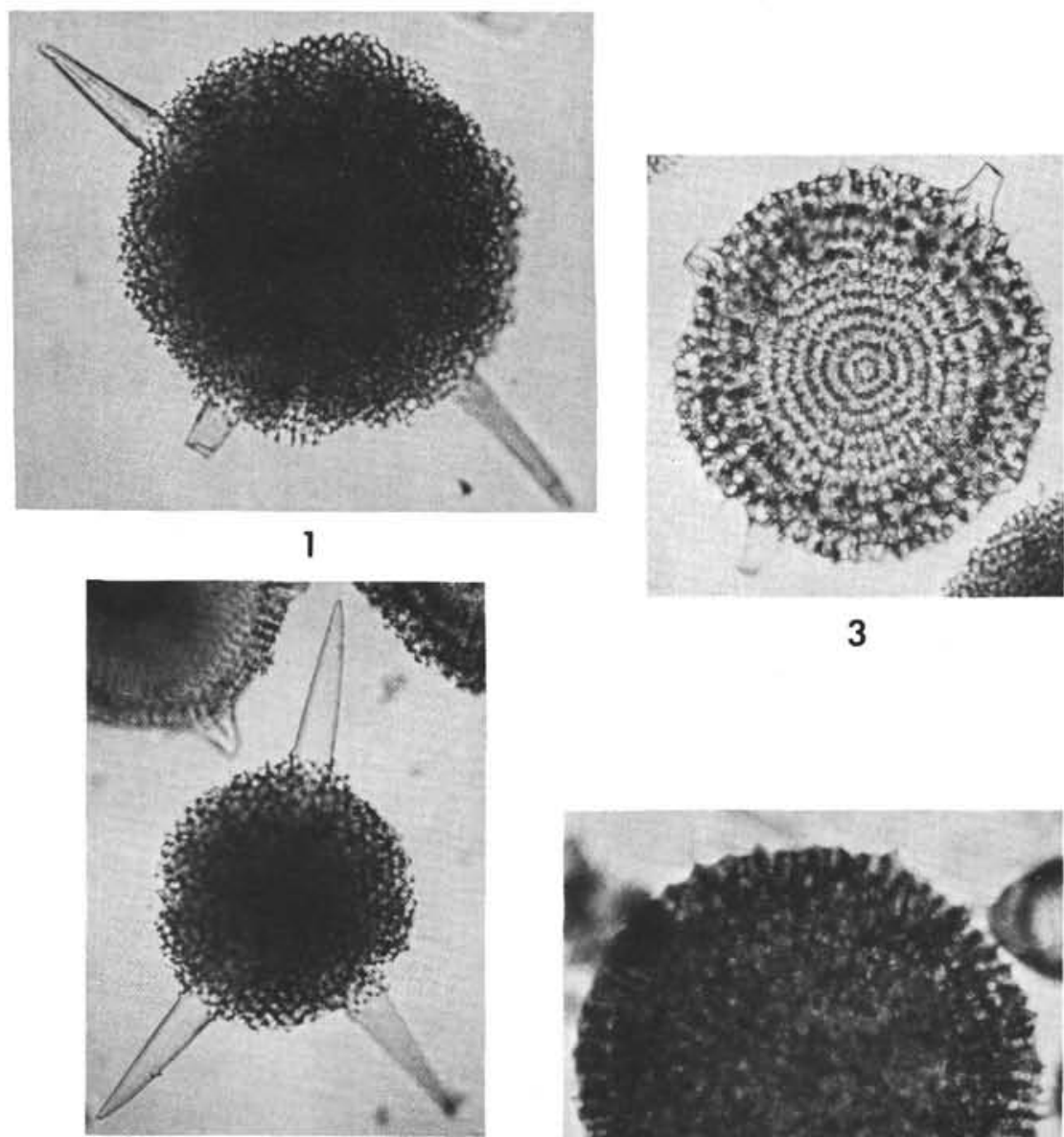

2
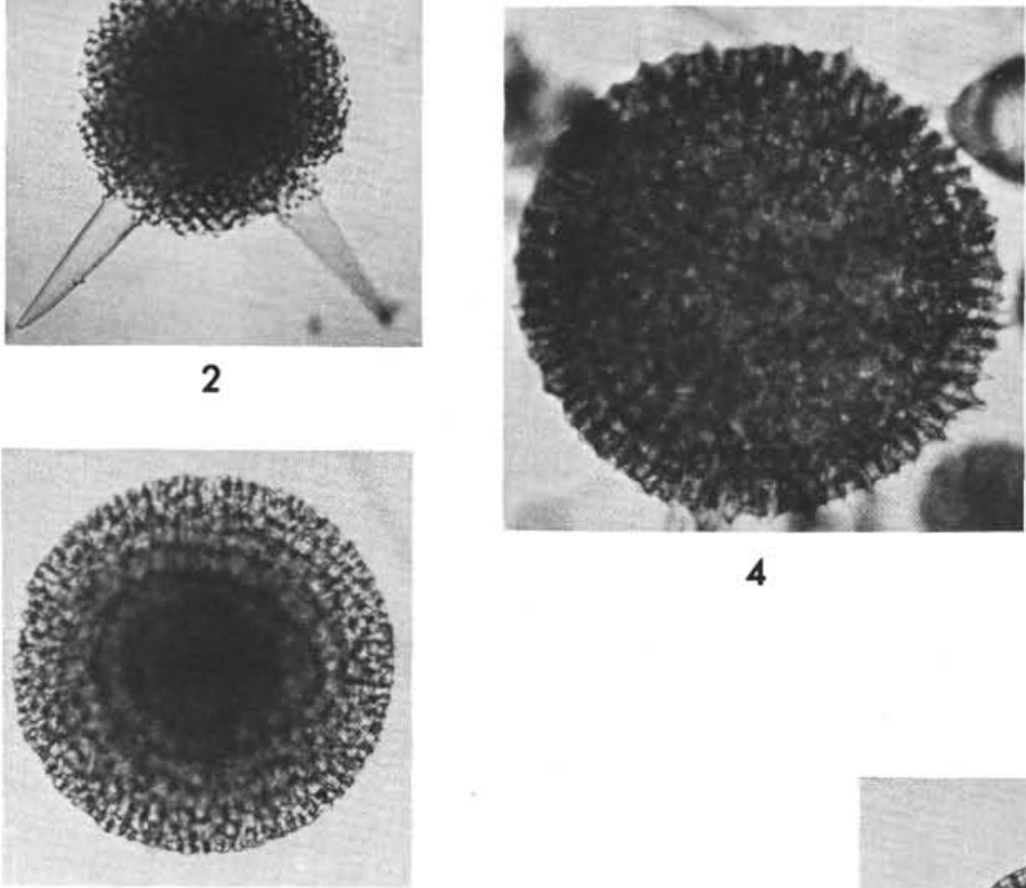

4

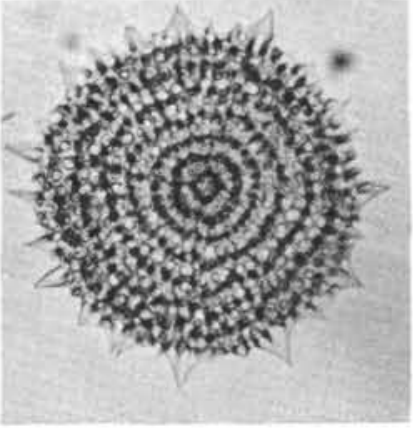

5

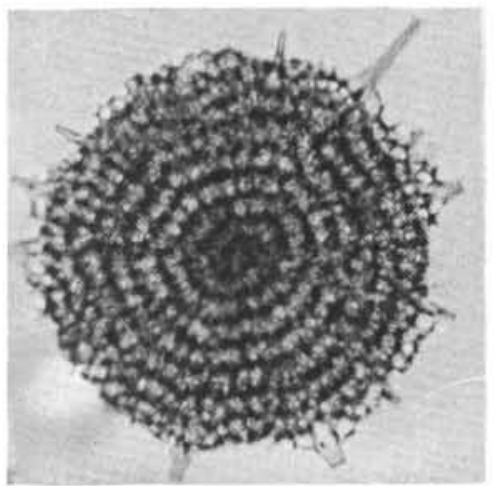

6

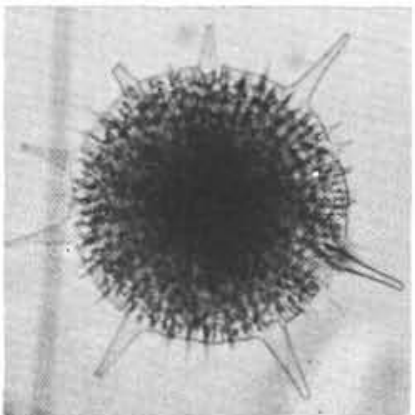

8

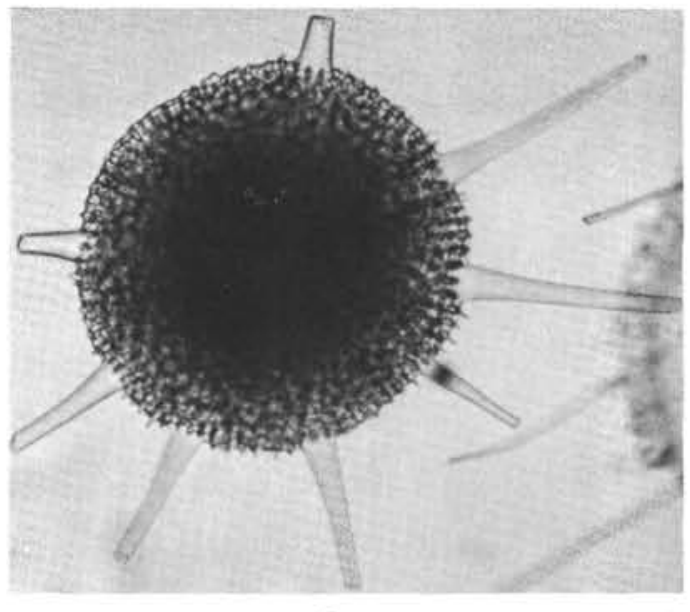

9 


\section{PLATE 31}

Figure 1 Stylotrochus quadribrachiatus quadribrachiatus Sanfilippo and Riedel, n. sp.

Holotype, 94-25-1 (42-44 cm), Cse. C, X31/0 $(165 \times)$

Figures 2, 3 Stylotrochus quadribrachiatus multibrachiatus Sanfilippo and Riedel, n. sp.

2. Holotype, 94-25-2 (42-44 cm), Cse., K44/2 $(165 \times)$

$$
\text { 3. } 94-25-2(42-44 \mathrm{~cm}) \text {, Cse., P32/0 (165 } \times)
$$

Figures 4-7 Xiphospira circularis (Clark and Campbell)

4. $95-8$ (CC), Cse. A, J14/4 (165X)

5. $95-8-1(44-46 \mathrm{~cm})$, Cse. C, L34/4 $(165 \times)$

6. $94-22-1(42-44 \mathrm{~cm})$, Cse. A, U25/0 (180X)

7. $96-3-6(42-44 \mathrm{~cm})$, Cse. $2, \mathrm{~S} 39 / 4(180 \times)$

Figures 8, $9 \quad$ Ceratospyris articulata Ehrenberg
8. 94-27 (CC), Ph. 1, P21/1 (255X)

9. 94-27 (CC), Ph. 1, V39/1 (255×)

Figure 10 Acanthodesmiid gen. et sp. indet. 94-22-4 (42-44 cm), S1. 2, T38/3 $(255 \times)$

Figure $11 \quad$ Dendrospyris acuta Goll

94-30-2 (114-116 cm), S1. 1, P47/2 (255×)

Figure 12 Dendrospyris (?) sp. cf. D. acuta Goll 94-30-2 (114-116 cm), Ph. 2, U15/2 (255×)

Figures 13, 14 Dendrospyris fragoides Sanfilippo and Riedel, n. sp. 13. Holotype, 96-3-4 (42-44 cm), Ph. 2, W47/3 $(255 \times)$

14. 96-3-5 $(42-44 \mathrm{~cm})$, Slide “ $<124 \mu \mathrm{A} ", \mathrm{Y} 41 / 2$ $(255 \times)$

Figure 15 Dendrospyris turriturcica turriturcica Sanfilippo and Riedel, n. sp.

Holotype, 94-28-3 (43-45 cm), S1. C, S29/3 (255×) 
PLATE 31
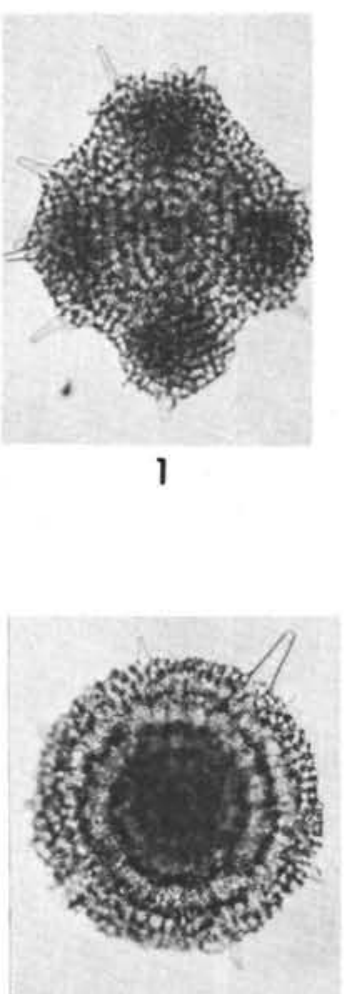

5

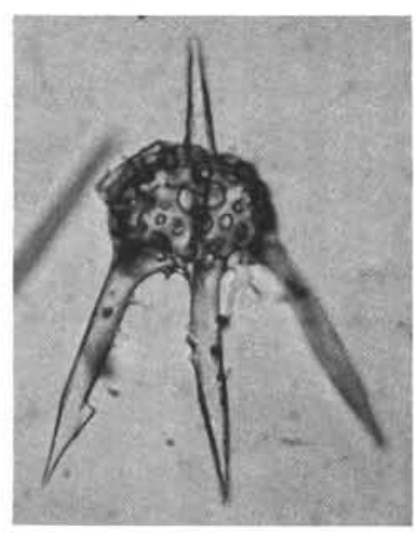

8

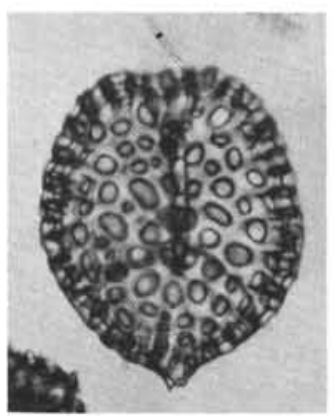

12

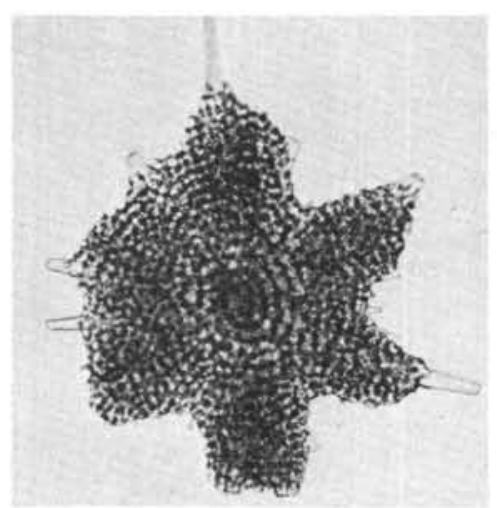

2

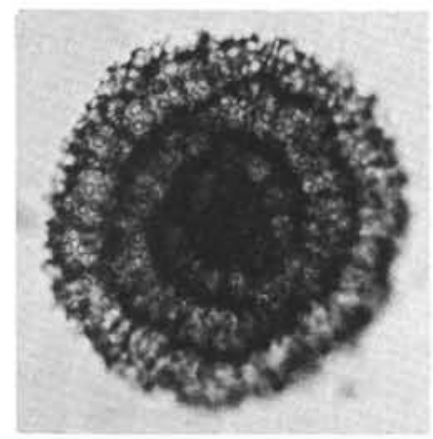

6
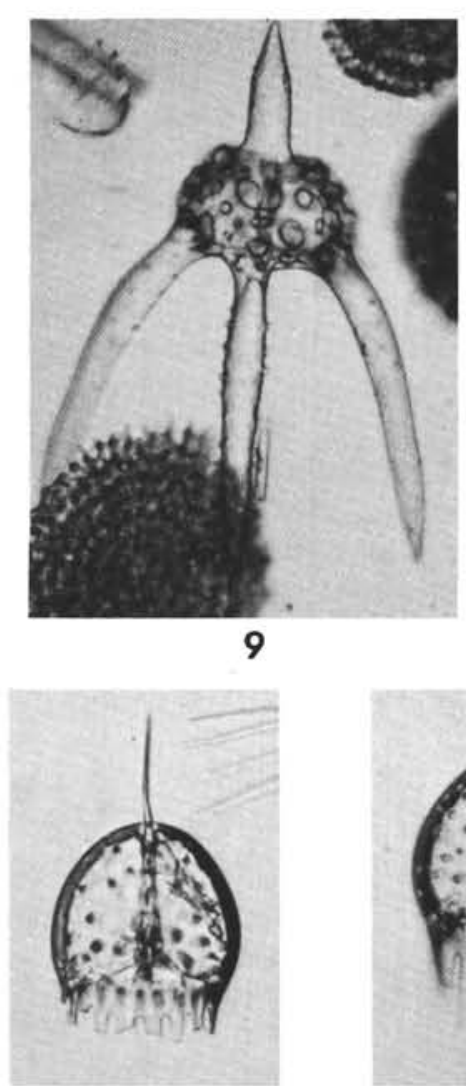

13
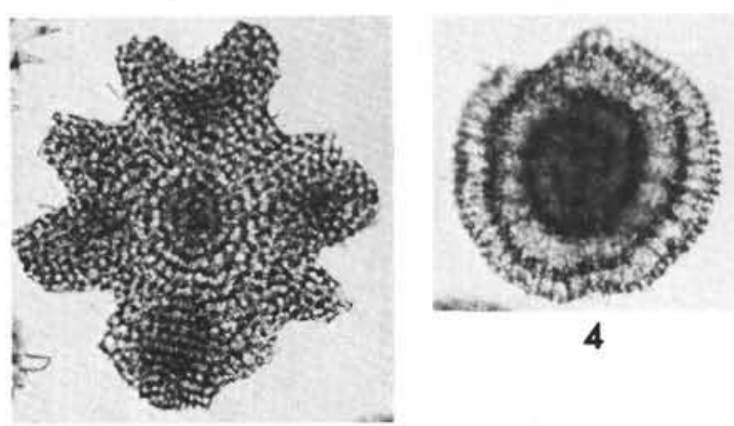

3

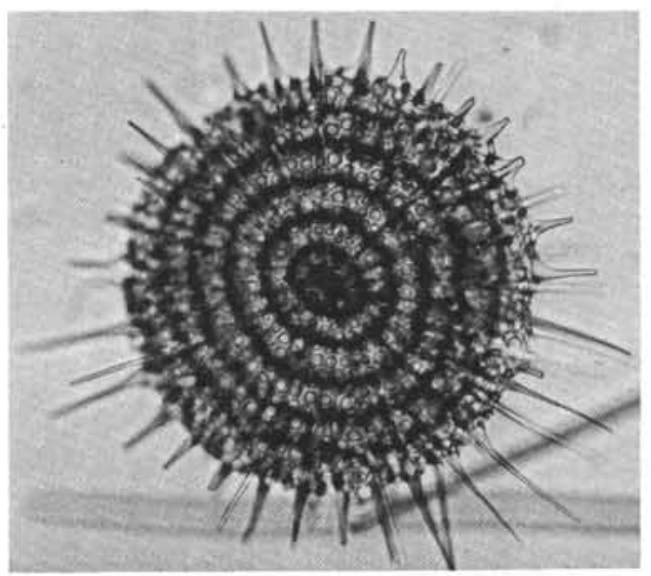

7

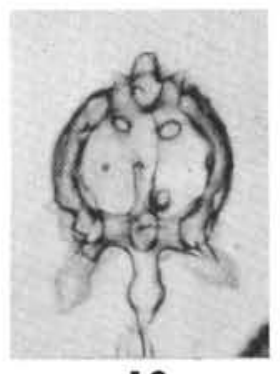

10

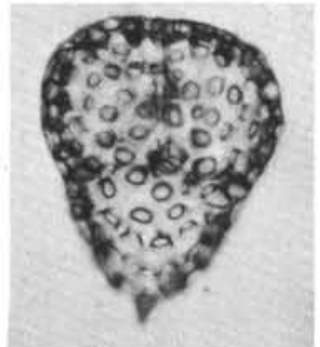

11

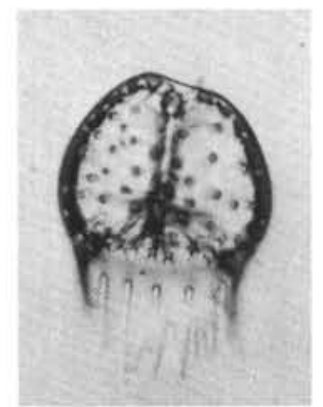

14

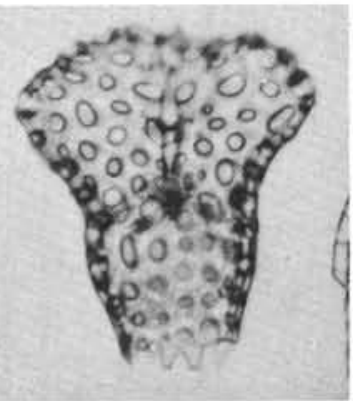

15 
PLATE 32

Figure 1 Dendrospyris turriturcica turriturcica Sanfilippo and Riedel, n. sp.

94-28 (CC), S1. C, F31/4 (255×)

Figure 2 Dendrospyris sp. cf. D. turriturcica Sanfilippo and Riedel

94-28-3 (43-45 cm), S1. C, Q28/1 (255×)

Figure 3 Dendrospyris turriturcica dasyotus Sanfilippo and Riedel, n. subsp.

Holotype, 94-28-3 (43-45 cm), S1. C, V36/0 (255×)

Figures 4-7 Dictyospyris discus Sanfilippo and Riedel, n. sp.

4. Holotype, 94-32 (CC), S1. 1, J48/0 (255×)

5. $96-3$ (CC), Cse. 1 , W $43 / 2(255 \times)$

6. $94-32$ (CC), Ph. 2 , U17/0 $(255 \times)$

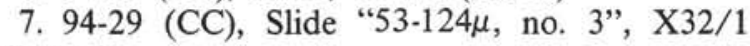
$(255 \times)$

Figures 8, 9 Dictyospyris sp. aff. D. discus Sanfilippo and Riedel 8. 94-29 (CC), Slide "53-124 , no. 3", X27/1 $(255 \times)$

9. $94-30-1(80-82 \mathrm{~cm})$, Ph. 2, C23/0 (255×)

Figures 10, 11 Dictyospyris gigas Ehrenberg

10. $94-30-1(80-82 \mathrm{~cm}), \mathrm{Sl}, 2, \mathrm{~V} 15 / 2(255 \times)$

11. $94-30-1(80-82 \mathrm{~cm})$, Sl. $2, X 7 / 0(255 \times)$

Figure 12 Dictyospyris sp. cf. D. gigas Ehrenberg

94-16 (CC), S1. 1, E27/2 (255×)

Figure 13 Dictyospyris melissium Sanfilippo and Riedel, n. sp. Holotype, 94-30-2 (114-116 cm), Sl. 1, F31/1 $(255 \times)$

Figures 14-18 Dictyospyris sphaera Bütschli

14. $94-28-5(43-45 \mathrm{~cm})$, Sl. 1, D33/0 $(255 \times)$

15. $94-30-2$ (114-116 cm), Ph. 2, Z13/3 (230×)

16. Broken specimen showing bars connecting sagittal ring with lattice-shell. 94-30-2 (114-116 cm), Ph. 2, T48/3 $(255 \times)$

17. $94-30-2(114-116 \mathrm{~cm})$, Cse. $1, \mathrm{C} 15 / 1(480 \times)$

18. $94-24-2(42-44 \mathrm{~cm})$, Sl. $1, \mathrm{M} 43 / 3(255 \times)$

Figures 19, 20 Dictyospyiris sp.cf. D. sphaera Bütschli

19. $94-16-2(42-44 \mathrm{~cm})$, Sl. $2, \mathrm{P} 32 / 3(255 \times)$

20. $94-14-3(42-44 \mathrm{~cm})$, Sl. $1, \mathrm{~J} 45 / 2(255 \times)$ 
PLATE 32

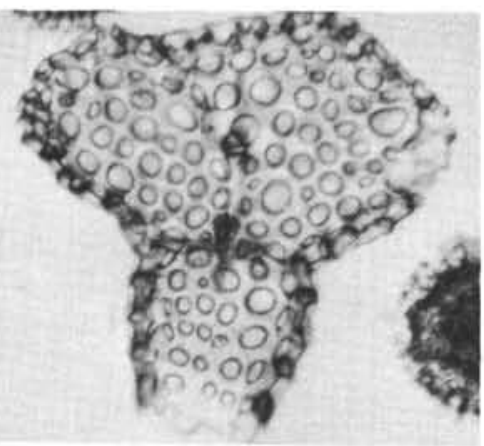

1

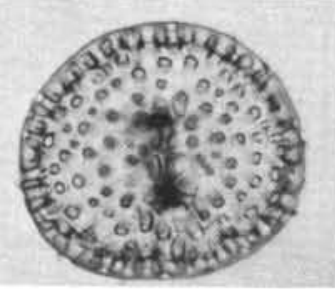

5

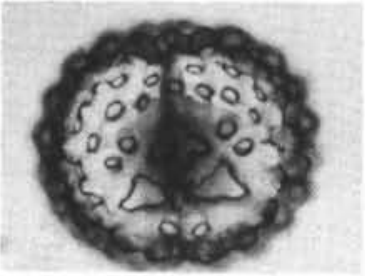

12

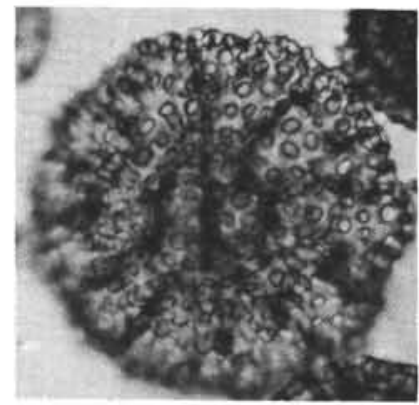

13

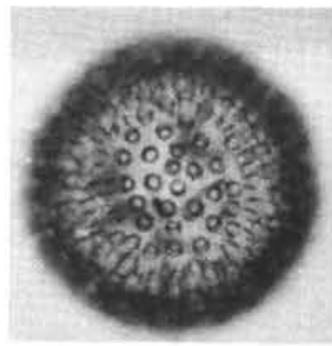

18
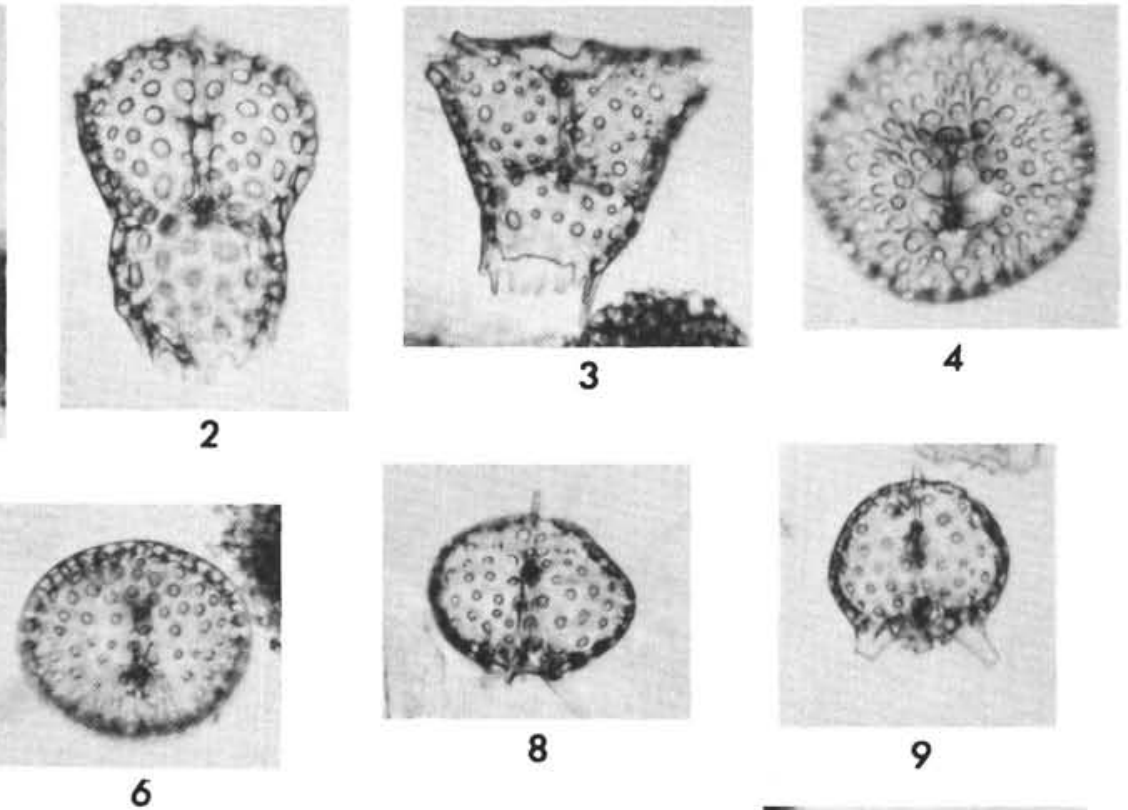

8

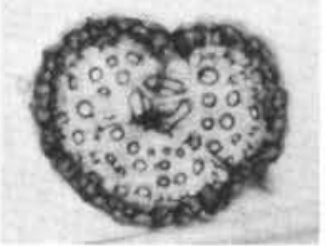

10

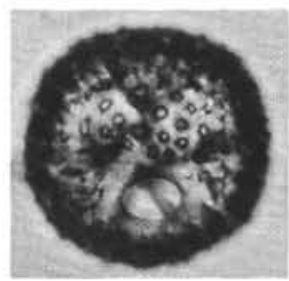

15

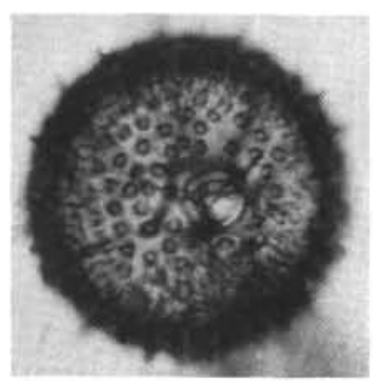

14

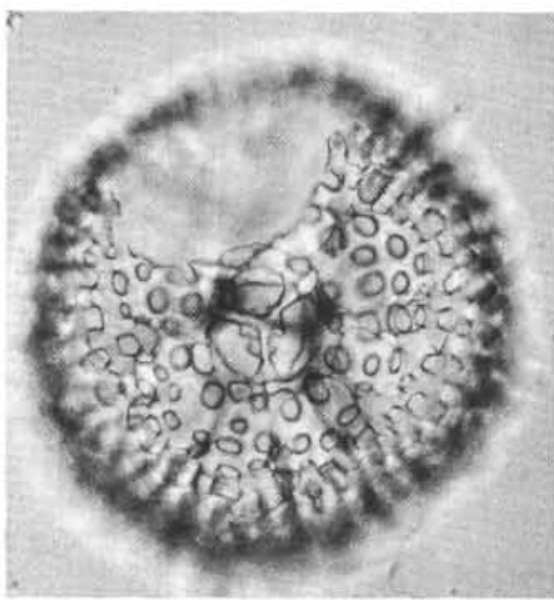

17
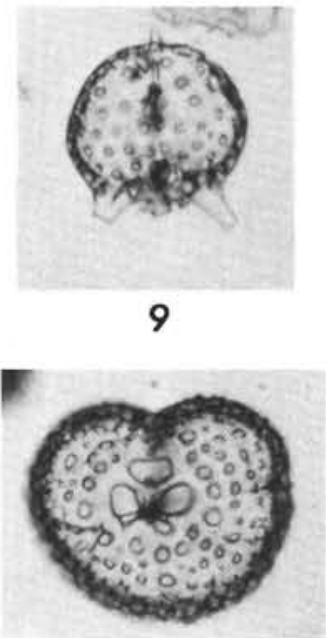

11

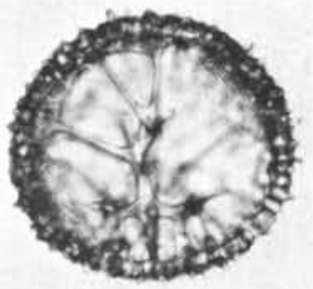

16

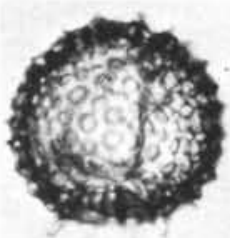

19

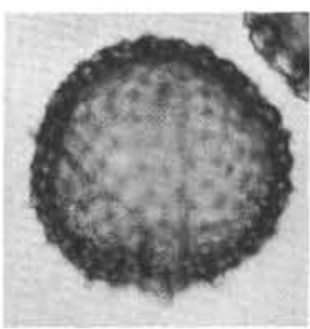

20 


\section{PLATE 33}

Figure 1 Dorcadospyris confluens (Ehrenberg)

94-28-3 (43-45 cm), Sl. C, M9/4 (255×)

Figure 2 Dorcadospyris platyacantha (Ehrenberg)

94-17-1 (36-38 cm), Sl. C, N36/3 (255×)

Figure 3 Giraffospyris cyrillium Sanfilippo and Riedel, n. sp. Holotype, 94-28-3 (43-45 cm), Sl. C, C22/2 (255×)

Figure $4 \quad$ Giraffospyris lata Goll

94-30-2 (114-116 cm), Sl. 1, R36/0 (255×)

Figures 5-8 Rhabdolithis ellida Sanfilippo and Riedel, n. sp.

5. Holotype, 96-3-6 (42-44 cm), Cse. 1, X38/1 $(165 \times)$

6. 96-3-6 (42-44 cm), Cse. 1, G26/3 (165×)

$7 \& 8$. Specimens oriented to show median bar and apical, vertical and lateral spines.

7. $96-3-4(42-44 \mathrm{~cm})$, Cse. 2 , U13/0 $(255 \times)$

8. 96-3-6 (42-44 cm), Cse. 1, G26/3 (165×)

Figures 9, $10 \quad$ Rhabdolithis pipa Ehrenberg

9. $94-21-2(118-120 \mathrm{~cm})$, Cse. 2, U29/4 (180X)

10. $94-17-1(36-38 \mathrm{~cm})$, Slide " $<124 \mu, \mathrm{A} ", \mathrm{~B} 46 / 3$ $(230 \times)$

Figure 11 Dictyophimus craticula Ehrenberg 95-8-6 (43-45 cm), Cse. 2, F18/0 (165×)

Figure 12 Dictyophimus sp. aff. D. craticula Ehrenberg 94-28-5 (43-45 cm), Cse. A, T43/4 (165×) 

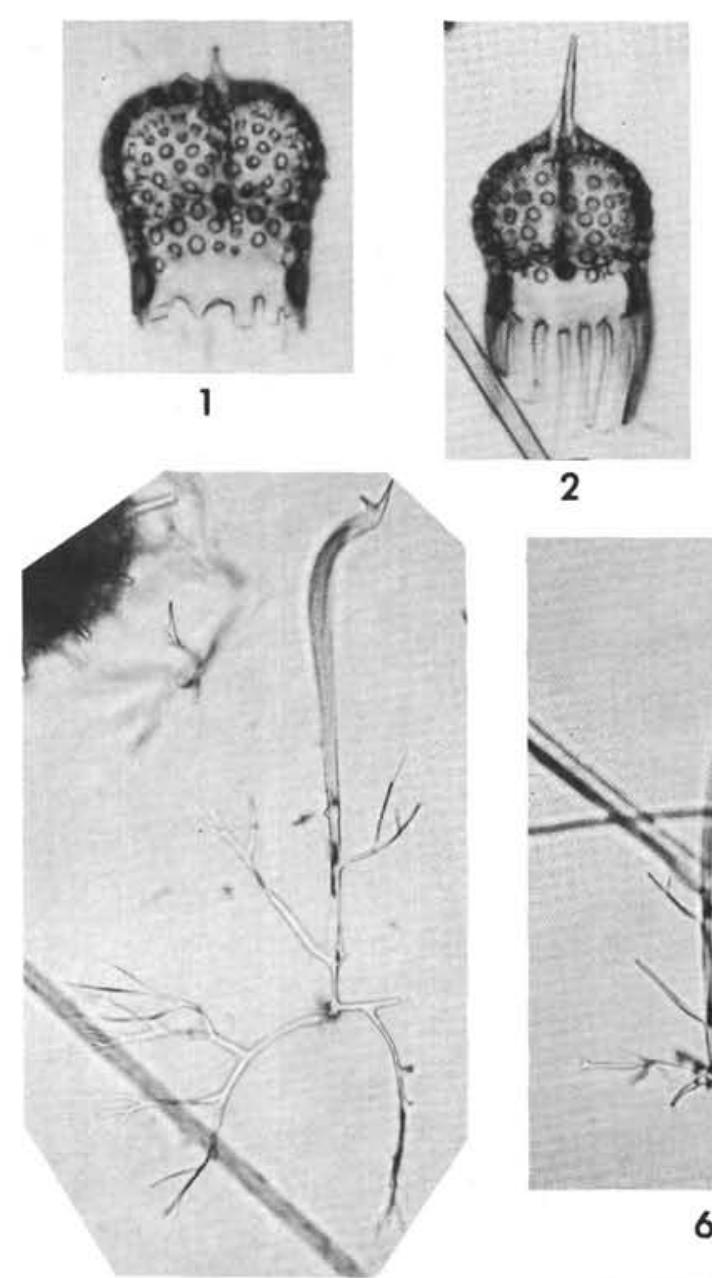

5

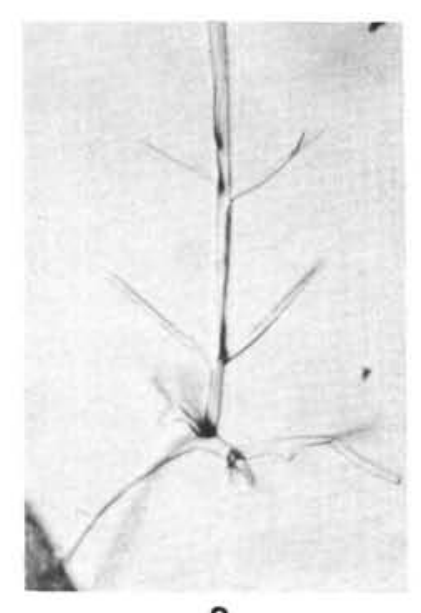

8

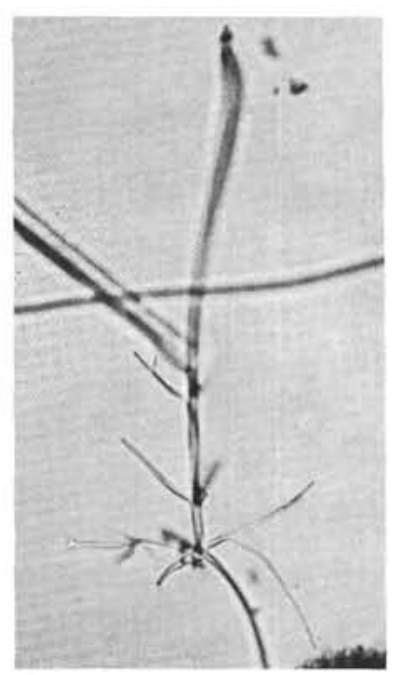

6

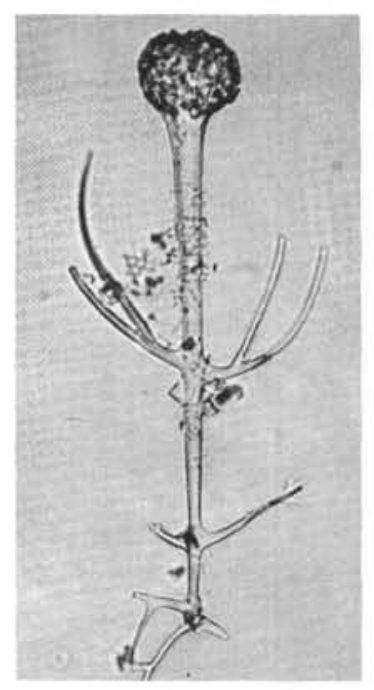

9

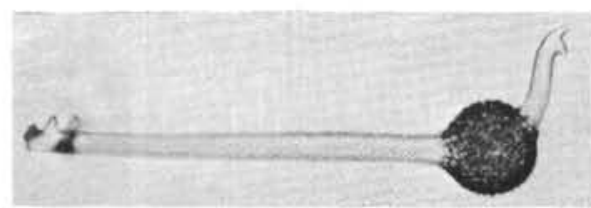

10
PLATE 33
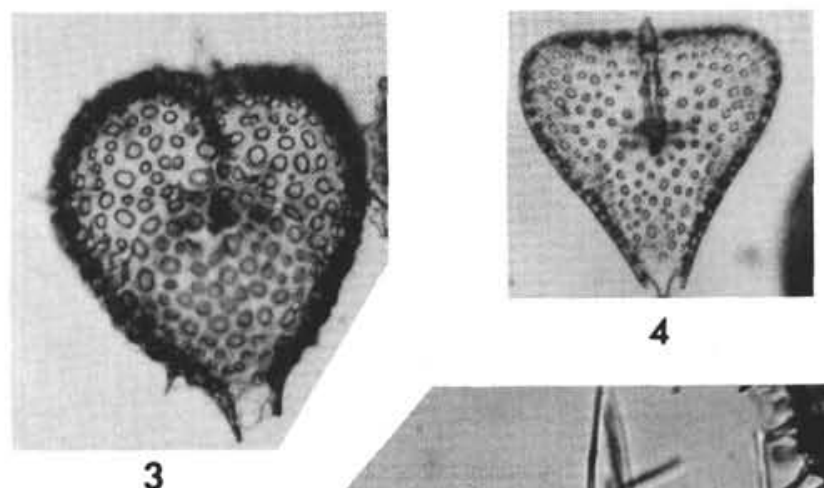

4
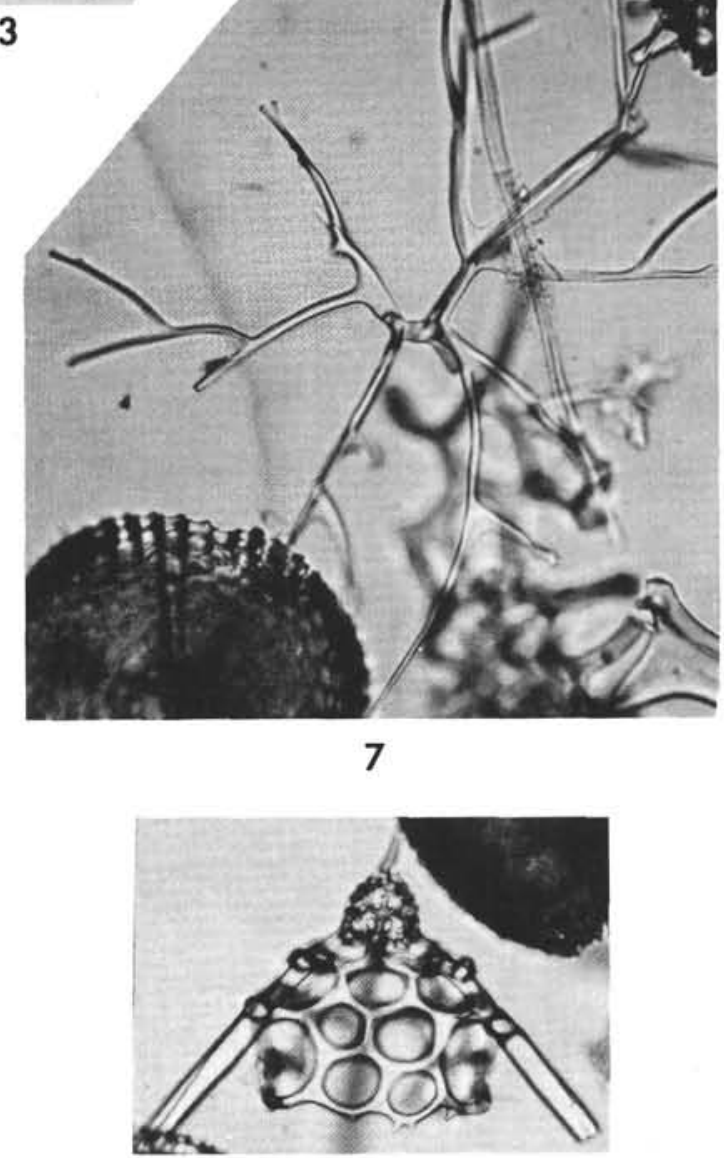

11

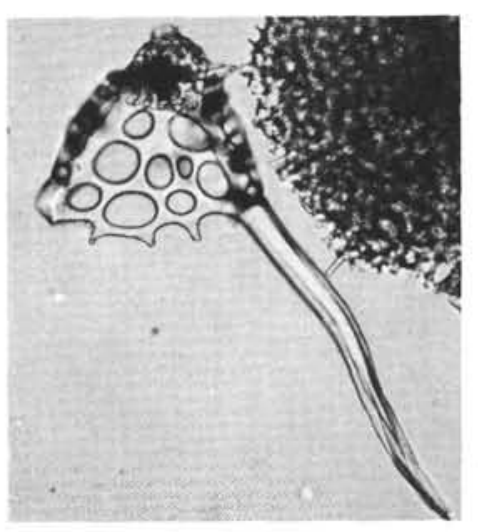

12 


\section{PLATE 34}

Figures 1-6 Spongomelissa adunca Sanfilippo and Riedel, n. sp.

1. 96-3-6 (42-44 cm), Cse. 1, R38/0 (165 $\times)$

2. 96-3-6 (42-44 cm), Cse. 1, Q48/1 (180X)

3. 96-3-6 (42-44 cm), Cse. 2 , W49/0 (180 $\times)$

4. Specimen showing lateral tube on left-hand side of cephalis. 96-3-5, 42-44 cm, Cse. F, H14/1 (230X)

5. Holotype, 96-3-6 (42-44 cm), Cse. 1, Q48/3 $(180 \times)$

6. $96-3-5$ (42-44 cm), Cse. G, L19/2 (180×)

Figures 7-10 Spongomelissa cucumella Sanfilippo and Riedel, n. sp.

7. Holotype, 94-30-2 (114-116 cm), Ph. 2, V19/1 $(230 \times)$

8. 94-30-2 (114-116 cm), Ph. 2, W48/1 (230×)

9. Specimen in oblique basal view, showing basal lattice. 94-30-2 (114-116 cm), Ph. 2, W45/3 (230×) 10. View through peristome, of collar structures. 94-30-2 (114-116 cm), Ph. 2, R25/1 (255×)

Figure $11 \quad$ Spongomelissa (?) sp.

94-29 (CC), Sl. 5, C11/4 (255×)

Figures 12, 13 Spongomelissa euparyphus Sanfilippo and Riedel, n. sp.

12. Holotype, view from below showing collar structure. 94-30-1 (80-82 cm), Cse. 2, E39/3 (180X) 13. View from above, indistinctly showing large tube over thoracic wall. 94-29 (CC), Slide "124$246 \mu$, no. 3", U14/2 (180×)

Figure $14 \quad$ Velicucullus sp.

View from above, focussed through cephalis on collar structure. 96-3-5 (42-44 cm), Cse. G, Q44/3 $(180 \times)$ 
PLATE 34

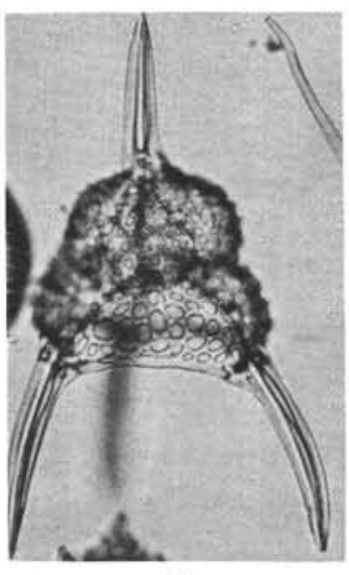

1

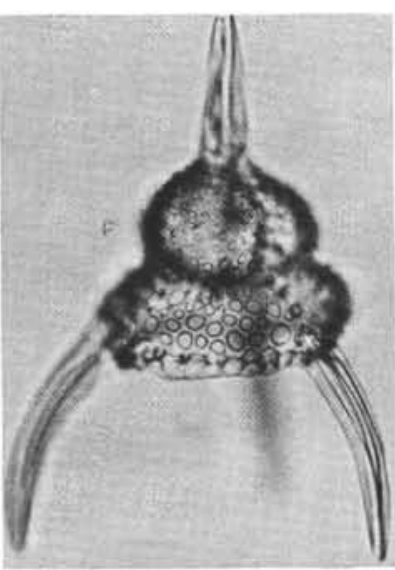

2

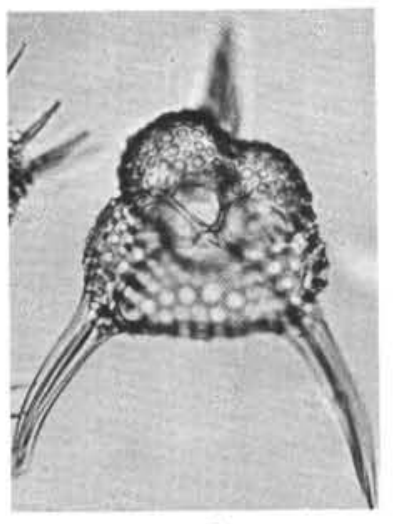

3

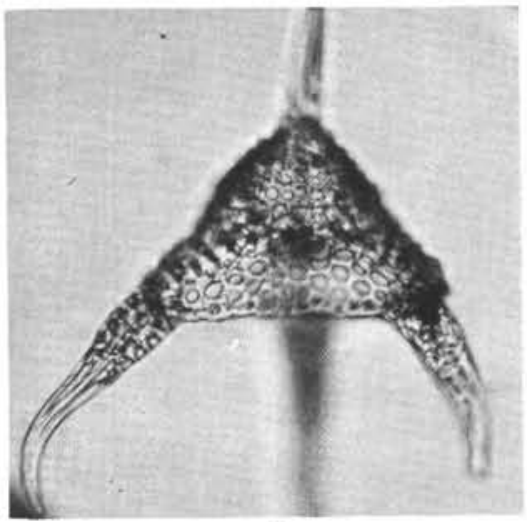

5

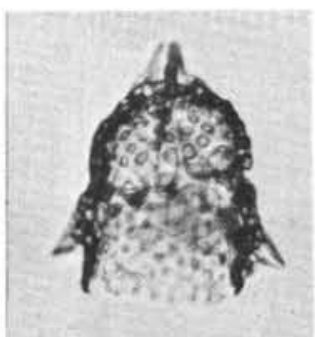

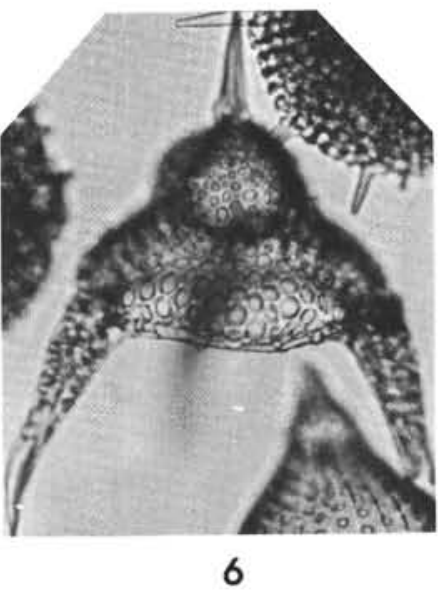

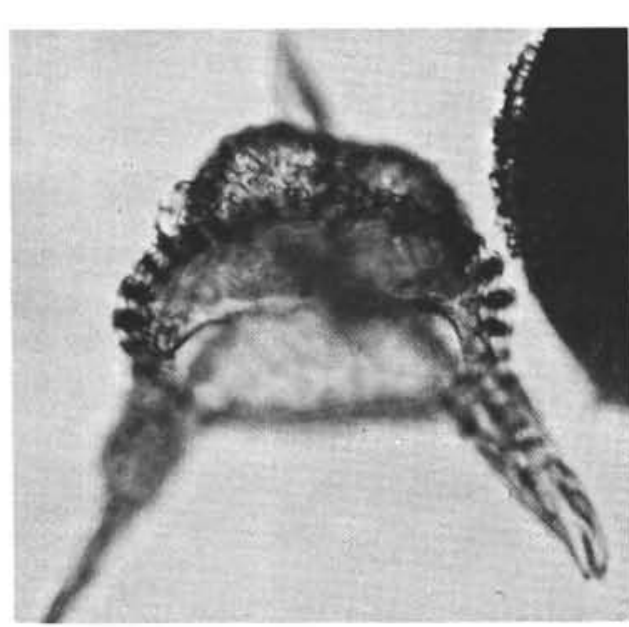

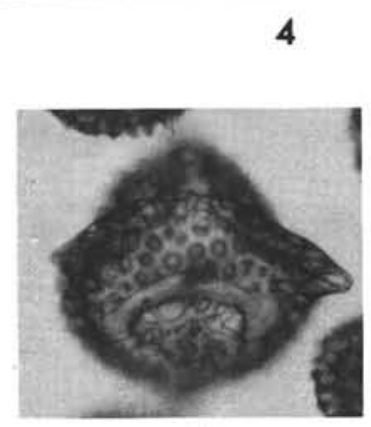

9

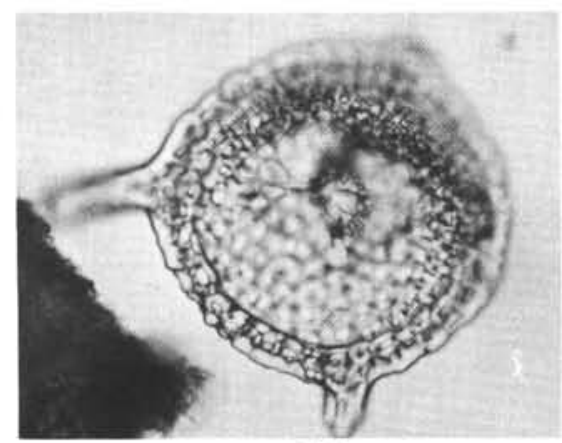

12
11

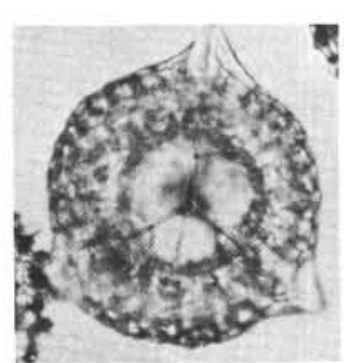

10

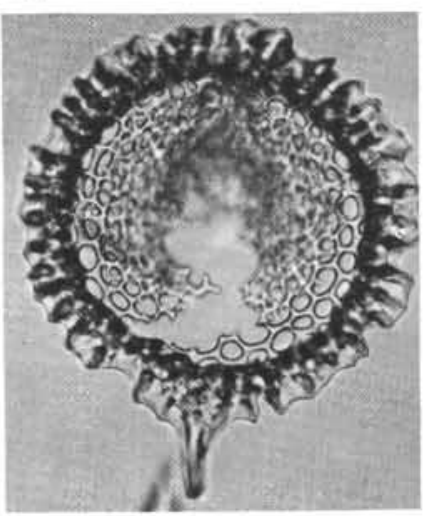

13
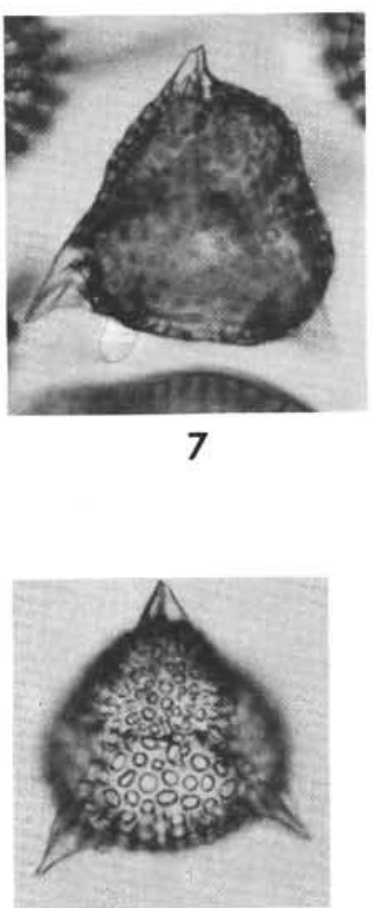

8

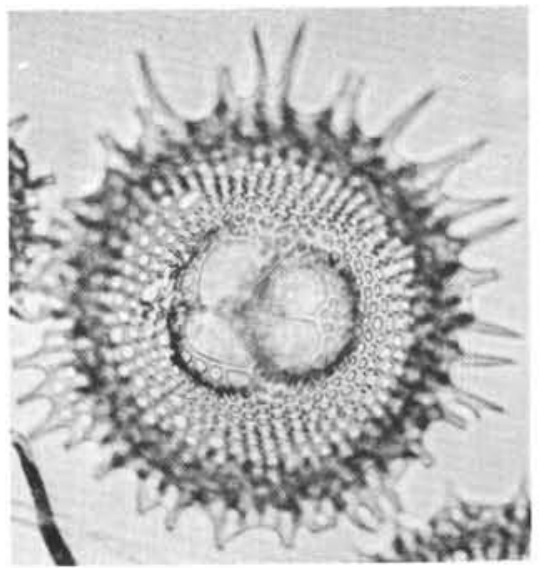

14 


\section{PLATE 35}

Figures 1, 2 Carpocanistrum $\mathrm{sp}(\mathrm{p})$.

1. $95-5-4(42-44 \mathrm{~cm})$, Sl. $1, \mathrm{R} 17 / 1(255 \times)$

2. $95-6-2(42-44 \mathrm{~cm}) \mathrm{Sl} .2, \mathrm{~T} 16 / 0(255 \times)$

Figures 3, $4 \quad$ Cryptoprora ornata Ehrenberg

3. $94-14-3(42-44 \mathrm{~cm}), \mathrm{S} 1.1, \mathrm{~V} 13 / 2(255 \times)$

4. $94-14-3(42-44 \mathrm{~cm})$, Sl. $1, \mathrm{R} 30 / 1(255 \times)$

Figure $5 \quad$ Cryptoprora sp. cf. C. ornata Ehrenberg 95-6-2 (42-44 cm), Sl. 2, R31/0 (255 X)

Figure 6 Theoperid gen. et. sp. indet. 94-17-4 (43-45 cm), Sl. 2, T13/1 $(255 \times)$

Figures 7, 8 Pterocoryid gen. et sp. indet.

7. $94-16-3(42-44 \mathrm{~cm}), \mathrm{Sl} .1, \mathrm{~V} 9 / 0(255 \times)$

8. Specimen with lateral cephalic tube. 86-6 (CC), S1. 2, P22/1 $(255 \times)$

Figure 9 Carpocancistrum (?) azyx Sanfilippo and Riedel, n. sp.

Holotype, 94-16-3 (42-44 cm), Sl. 1, V37/1 (255×)

Figures 10, 11 Podocyrtis diamesa Riedel and Sanfilippo 10. 94-21-2 (42-44 cm), Cse. 1, U34/4 (180×) 11. $94-21-2(42-44 \mathrm{~cm})$, Cse. $1, \mathrm{~V} 49 / 0(180 \times)$

Figures 12-14 Podocyrtis dorus Sanfilippo and Riedel, n. sp.

12. $94-20-4(42-44 \mathrm{~cm})$, Sl. 2, L38/2 (165X)

13. Holotype, $94-22-4(42-44 \mathrm{~cm})$, Cse. $2, \mathrm{M} 27 / 3$ $(165 \times)$

14. $94-20-4(42-44 \mathrm{~cm})$, Cse. 2 , F14/0 (165 $\times)$ 


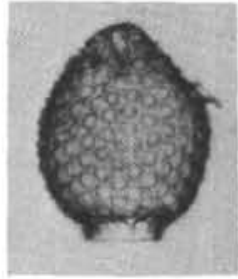

1

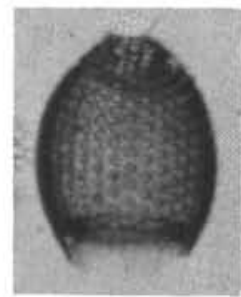

5

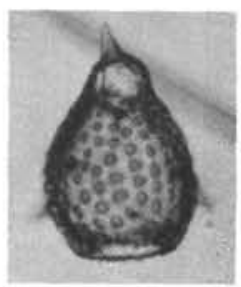

6

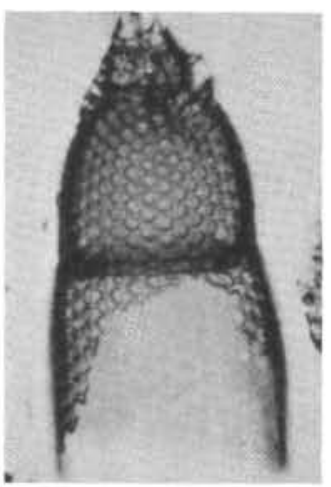

8

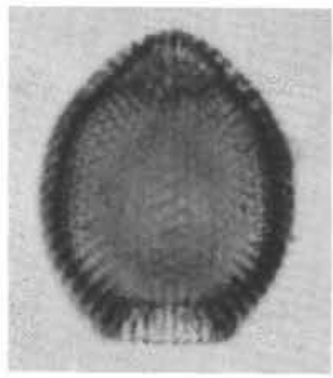

9
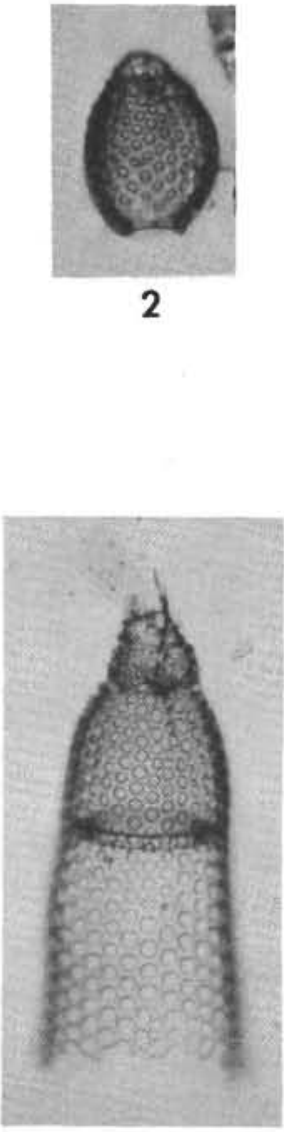

7

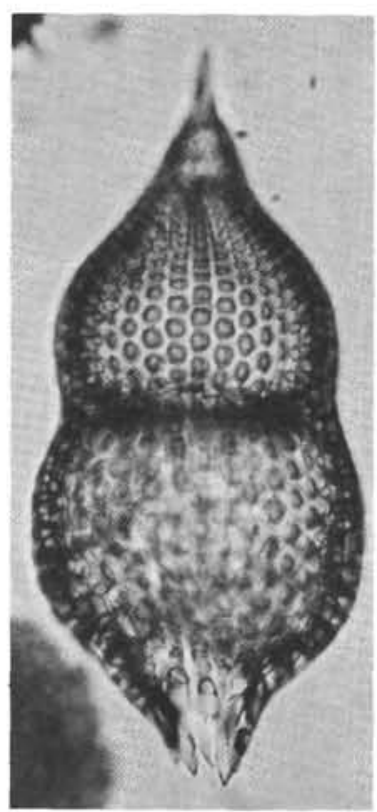

12
PLATE 35

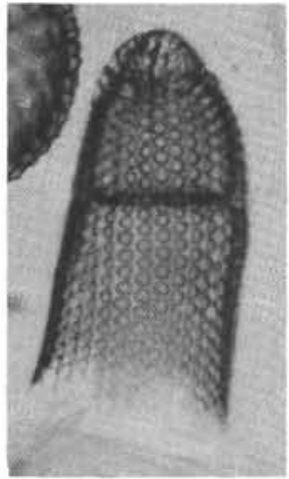

3
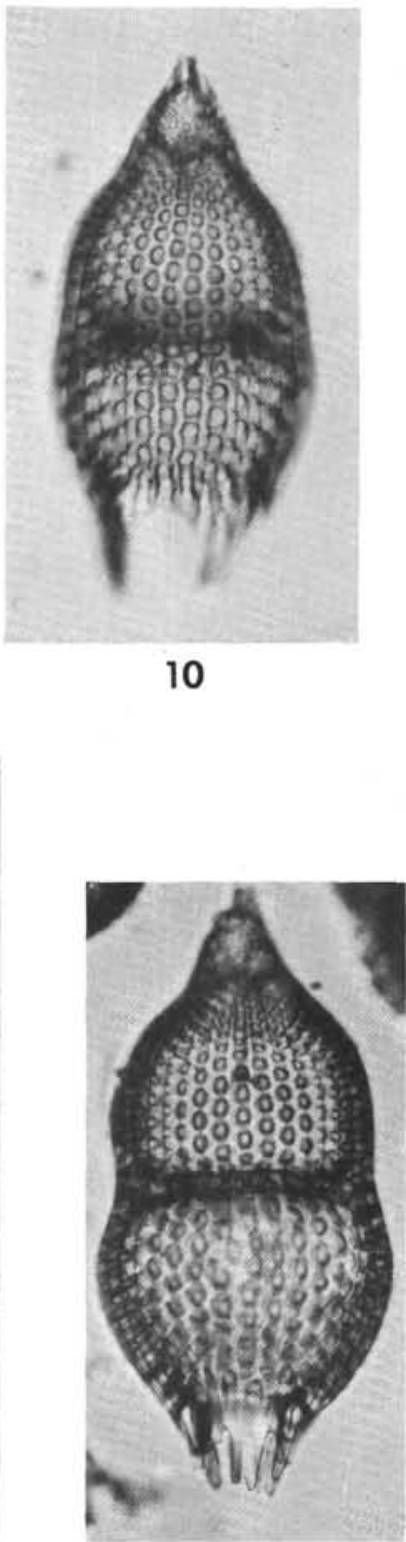

13

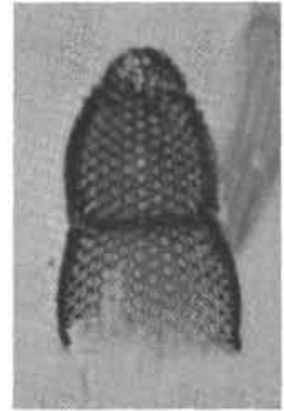

4

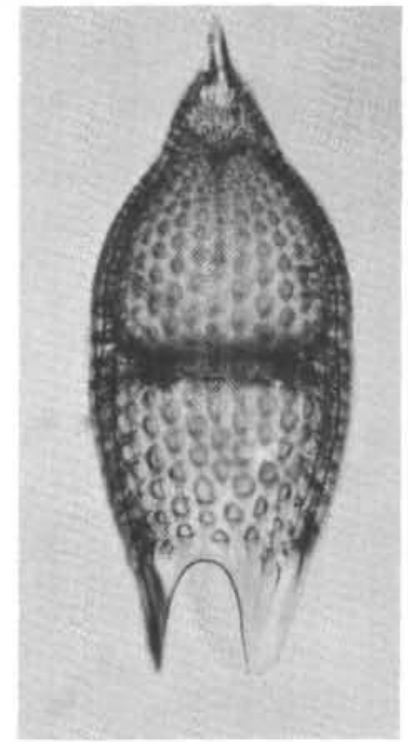

11

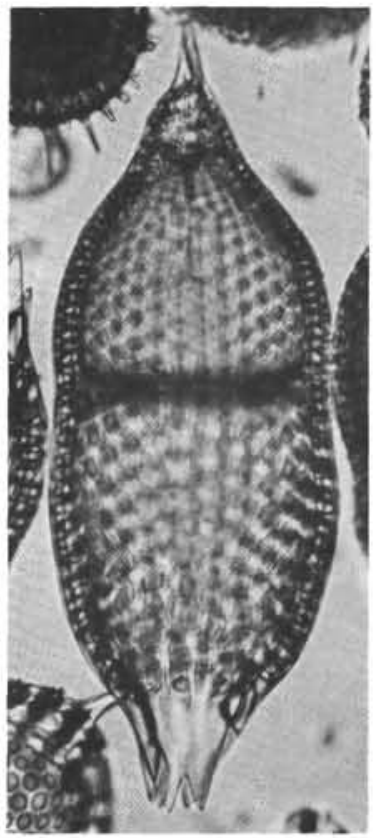

14 


\section{PLATE 36}

Figure $1 \quad$ Podocyrtis (?) sp. cf. P. papalis Ehrenberg 96-5 (CC), Sl. A, O28/3 (230×)

Figures 2, $3 \quad$ Podocyrtis papalis Ehrenberg

2. $96-4$ (CC), Sl. 1A, K36/4 (230×)

3. $94-30$ (CC), Cse. C, P33/3 (230×)

Figures 4, $5 \quad$ Podocyrtis platypus Sanfilippo and Riedel, n. sp. 4. Holotype, 94-28-2 (42-44 cm), Cse. 2, G48/0 $(165 \times)$

5. $94-28-2(42-44 \mathrm{~cm})$, Cse. $2, \mathrm{~S} 39 / 0(165 \times)$

Figures 6-8 Cannobotryids gen(n). et $\mathrm{sp}(\mathrm{p})$. indet.

6. $94-28-2(42-44 \mathrm{~cm}), \mathrm{Sl} .1, \mathrm{~K} 18 / 4(480 \mathrm{X})$

7. $94-30-1(80-82 \mathrm{~cm}), \mathrm{Ph} .2$, W $43 / 2(480 \times)$

8. $96-3-4(42-44 \mathrm{~cm})$, Sl. 1 , U20/4 $(480 \times)$

Figures 9-11 Sketches of the cephalic structure of a cannobotryid (fig. 9) and apparently related forms (figs. 10, 11) from Core 96-3. Forms constructed as in fig. 9 are very rare, fig. 10 rare, and fig. 11 moderately rare. A, apical spine; D, dorsal bar and spine; Vert, vertical bar and spine; $\mathrm{L}$ and 1, primary and secondary lateral bars, respectively; DB, dorsal branch; a, anterior appendages; ap, "ap" arch.

Figures 12, 13 Centrobotrys petrushevskayae Sanfilippo and Riedel, n. sp.

12. Holotype, 95-5-2 (42-44 cm), Ph. 1, 016/0 $(230 \times)$

13. $95-5-2(42-44 \mathrm{~cm}), \mathrm{Ph} .1$, W33/0 (230×) 

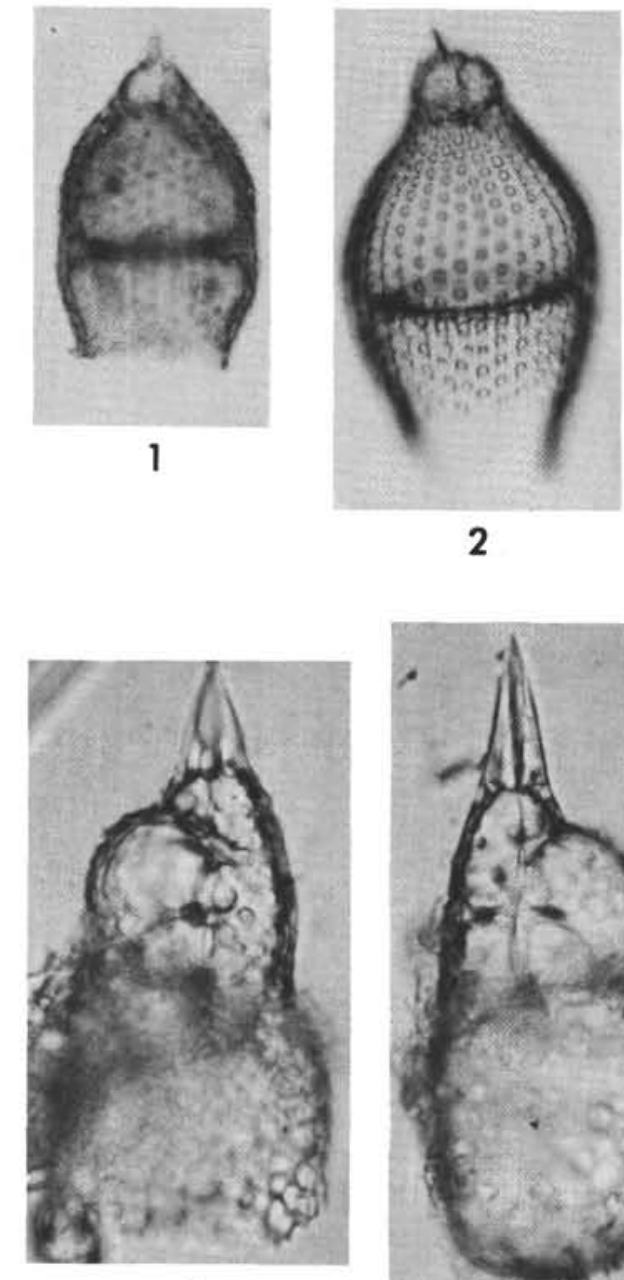

6

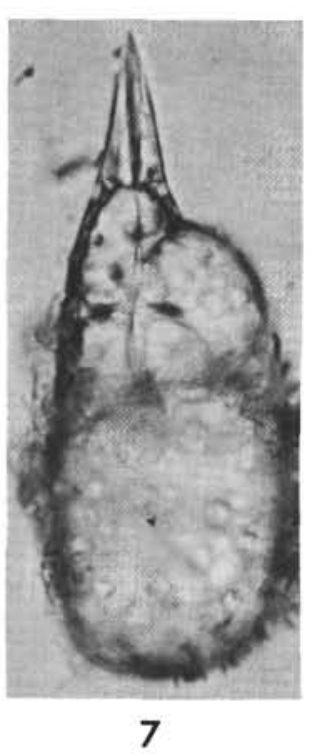

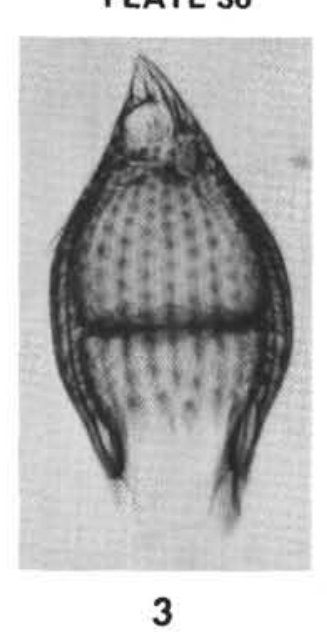

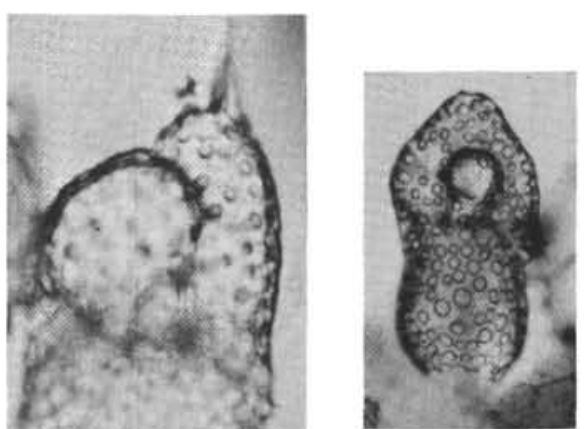

12

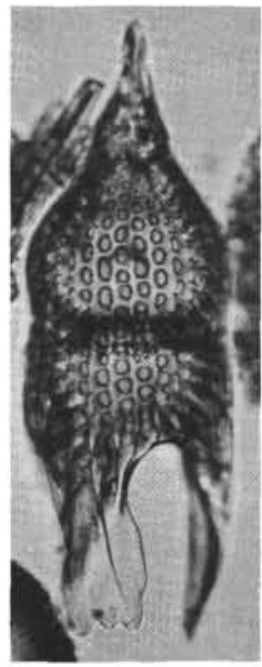

5

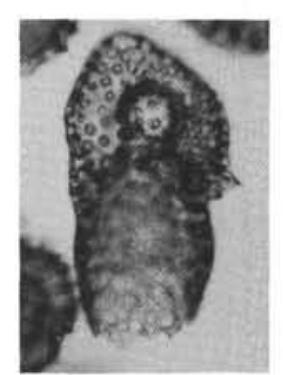

13

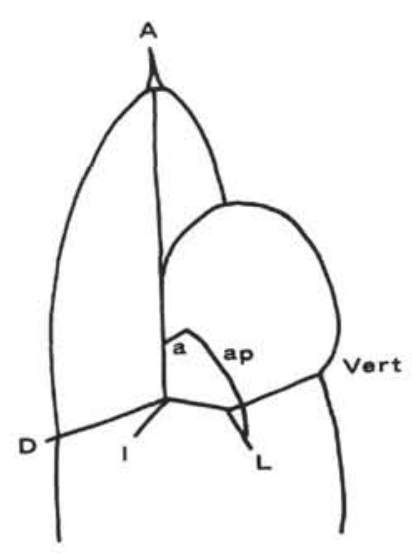

9

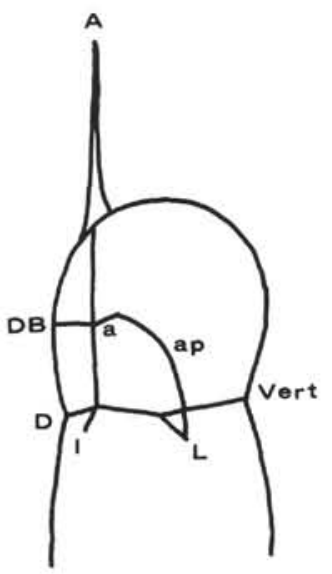

10

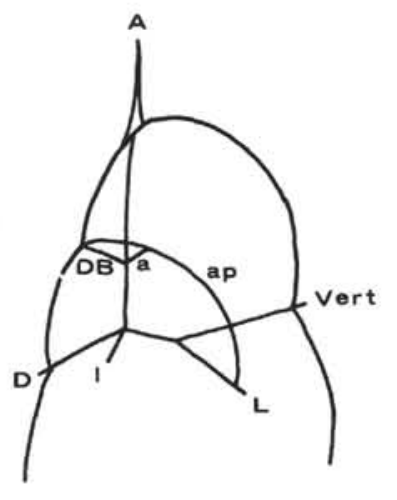

11 


\section{INDEX OF RADIOLARIAN NAMES}

Only genus-group and species-group taxa are indexed, and references are to numbered sections of the text and not to pages. In order to facilitate use of the index for taxa for which there are many entries, the principal reference and illustrations are printed in bold face, and this is preceded by entries referring to brief mentions in discussion, and followed by entries referring to occurrences and stratigraphic range.

Acanthodesmia, 8(7)

Acrobotrys, 8(11)Aa

spp., 8(11)Aa; Tab. 1, 3, 5, 7, 9; 6a; Fig. 6

Actinomma

inerme, $8(2) \mathrm{P}$

undosa, 8(2)Pc

Amphicraspedum, 8(6)A

maclaganium, 8(6)A

murrayanum, 8(6)Ac; 8(6)C; 8(6)Aa; Pl. 10, figs. 3-6; Pl. 28, fig. 1; Tab. 2, 4, 6, 8, 9; 6d; Fig. 5

prolixum, 8(6)Ab; Pl. 10, figs. 7-11; Pl. 28, figs. 3, 4; Tab. 2, 4, 6, 8, 9; Fig. 5

prolixum group, 8(6)Ac; Pl. 11, figs. 1-5; Pl. 28, fig. 5; Tab. 2, 4, 6, 8, 9; Fig. 5

Amphisphaera, 8(2)A

minor, 8(2)Ja; 8(2)Aa; Pl. 1, figs. 1-5; Pl. 22, fig. 4; Tab. 2-4, 6, 8; 6a; 6b; Figs. 5, 6

neptunus, 8(2)A

Amphiternis

clava, Tab. 9

sp. cf. Stichomitra alamedaensis, Tab. 9

Amphymenium, 8(6)B

splendiarmatum, 8(6)Ab; 8(6)Ac; 8(6)Ba; PI. 11, figs. 6-8; Pl. 28, figs. 6-8; Tab. 2, 4, 6, 8, 9; 6c; Fig. 5

zygartus, $8(6) \mathrm{B}$

Artophormis

barbadensis, Tab. 9; Fig. 6

dominasinensis, Tab. 9; Fig. 6

gracilis, Tab. 9; Fig. 6

Artostrobium

miralestense, Tab. 9; Fig. 6

sp. aff. A. doliolum, Tab. 9; Fig. 6

Astrophacus, 8(4)C; 8(4)A

asteriscus, 8(4)A

cingillum, $8(4) \mathrm{C}$

linckiaformis, 8(4)Aa; PI. 7, figs. 11, 12; Pl. 26, fig. 9, Tab. 2, 4, 6, 8,9 ; 6c; Fig. 5

Astrosphaerins, 8(2)B

sp. A, 8(2)Ba; Pl. 5, figs. 1, 2; Pl. 22, fig. 5; Tab. 2, 4, 8, 9; 6b; Fig. 5

sp. B, 8(2)Bb; Pl. 5, figs. 3, 4; Pl. 22, fig. 7; Tab. 2, 4, 8, 9; Fig. 5 sp. C, 8(2)Bc; Pl. 5, figs. 5, 6; Pl. 22, fig. 8; Tab. 2, 4, 8, 9; Fig. 5 sp. D, 8(2)Bd; Pl. 6, figs. 1, 2; Pl. 22, fig. 9; Tab. 2, 4, 8, 9; 6b; Fig. 5

sp. E, 8(2)Be; PI. 6, figs. 3-6; Pl. 23, fig. 1; Tab. 2, 4, 8, 9; 6b; Fig. 5

sp. F, 8(2)Bf; Pl. 6, figs. 7, 8; Pl. 23, fig. 2; Tab. 2, 4, 8, 9; 6b; Fig.

Astrostylus, 8(4)B

Axoprunum, $8(2) \mathrm{Pa} ; \mathbf{8 ( 2 ) C}$

pierinae group, 7; 8(2)Aa; 8(2)Ca; PI. 1, figs. 6-12; Pl. 23, fig. 3; Tab.

Bekoma $2,4,6,8 ; 6 \mathrm{~b} ; 6 \mathrm{c}$; Fig. 5

bidarfensis, Tab. 9

campechensis, Tab. 9

demissa, Tab. 9

divaricata, Tab. 9

Botryocyrtis, 8(11)B

caputserpentis, 8(11)B

spp., 8(11)Ba; Tab. 1, 3, 5, 7, 9; 6a; Fig. 6

Botryopyle, 8(11)C

dictyocephalus group, 8(11); 8(11)Cb; Tab. 1, 3, 5, 7; 6a; 6d sethocorys, 8(11)C

sp. A, 8(11)Ca; Tab. 1, 3, 5, 7, 9; Fig. 6
Brachiospyris alata, 8(7)Da

Buryella

clinata, Tab. 9

pentadica, Tab. 9

tetradica, Tab. 9

Calocyclas

costata, 8(10)Aa

hispida, Tab. 9; Fig. 6

turris, Tab. 9; Fig. 6

virginis, 8(10)Ab

Calocycletta, 8(10)A

costata, 8(10)Aa; Tab. 3, 5, 7, 9; 6a; Fig. 6

virginis, 8(10)Ab; Tab. 1, 3, 5, 7, 9; 6a; Fig. 6

Calocycloma

ampulla, Tab. 9; Fig. 6

castum, Tab. 9

Cannartidium mammiferum, 8(2)Da

Cannartus, 8(2)D

laticonus, $6 \mathrm{a}$

mamifer 8(2)Da; Tab. 3, 9; 6a; Fig. 6

prismaticus, 8(2)Db; Tab. 1, 3, 5, 7, 9; Fig. 6

tubarius, 8(2)Dc; Tab. 3, 5, 7, 9; Fig. 6

violina, 8(2)Dd; Tab. 3, 5, 7, 9; Fig. 6

Carpocanistrum, 8(9); 8(9)A

?azyx, 8(9); 8(9)Aa; Pl. 35, fig. 9; Tab. 1, 3, 4, 5; 6e; Fig. 6

Carpocanopsis, 8(9)B

bramlettei, 8(9)Ba; Tab. 3, 5, 7, 9; 6a; Fig. 6

cingulata 8(9)Aa; 8(9)Bb; Tab. 1. 3.5, 7, 9; 6a; Fig. 6

cristata?, 8(9)Bc; Tab. 3, 5, 7, 9; 6a; Fig. 6

favosa, 8(9)Bd; Tab. 3, 5, 7, 9; Fig. 6

Carposphaera, 8(2)E

buxiformis, $8(2) \mathrm{Oa}$

melitomma, 8(2)E

subbotinae, 8(2)Ea; Pl. 4, fig. 3; Pl. 23, figs. 4, 5; Tab. 2, 4, 6, 8; 6b; 6 d; Fig. 5

Cenosphaera, 8(2)F

megachile, $8(2) \mathrm{Fa}$

micra, 8(2)Fa

mitgarzi, 8(2)Fa

plutonis, 8(2)F

sp. A, 8(2)Fa; Pl. 4, fig. 4; Pl. 23, fig. 6; Tab. 2, 4, 6, 8, 9; Fig. 5 subbotinae, $8(2) \mathrm{Ea}$

Centrobotrys, 8(11)D

gravida, 7; 8(11)Db; 8(11)Da; Tab. 1, 3, 5, 7, 9; Fig. 6

petrushevskayae, 7; 8(11)Db; Pl. 36, figs. 12, 13; Tab. 1, 3, 5, 7, 9; Fig. 6

?sp. 6

?sp. A, 8(11)Db

thermophila, 7; 8(11)D; 8(11)Db; 8(11)Dc; Tab. 1, 3, 5, 7, 9, 6a; Fig. 6

Ceratospyris, 8(7)A

articulata, 8(7)Aa; Pl. 15, figs. 1-3; Pl. 31, figs. 8, 9; Tab. 2-6, 8, 9; Figs. 5, 6

ateuchus, $8(7) \mathrm{Db}$

borealis, $8(7) \mathrm{A}$

heptaceros, 8(7)E

stylophora, 8(7)B

triceros, 8(7)Ia

Cladospyris, 8(7)A

moluccans, 8(7)A

Clathrocycloma

capitaneum, Tab. 9

parcum, Tab. 9

Cornutella mitra, $8(2) \mathrm{Kb}$

Cromyatractus tetracelyphus, $8(2) \mathrm{Nc}$

Cromydruppocarpus, $8(2) \mathrm{N}$

esterae, $8(2) \mathrm{N}$

Cryptoprora ornata, 8(9); PI. 35, figs. 3, 4

Cycladophora

favosa, 8(9)Bd

goetheana, $8(10) \mathrm{Bi}$ 
Cyclampterium

leptetrum. Tab. 9; Fig. 6

milowi, Tab. 9; Fig. 6

pegetrum, Tab. 9; Fig. 6

Cyrtocapsella

cornuta, Tab. 9; Fig. 6

elongata, Tab. 9; Fig. 6

tetrapera, Tab. 9; Fig. 6

Dendrospyris, 8(7)B

acuta, 8(7)Ba; PI. 15, fig. 5; PI. 31, fig. 11; Tab. 2, 4, 6, 8, 9; Fig. 5

fragoides, 8(7)Bb; Pl. 15, figs. 8-13; Pl. 31, figs. 13, 14; Tab. 2-6, 8; 6b; 6d; Fig. 5

turriturcica dasyotus, 7; 8(7)Bd; PI. 16, fig. 3; PI. 32, fig. 3; Tab. 4, 9; Fig. 5

turriturcica turriturcica, 7; 8(7)Bd; 8(7)Bc; PI. 16, fig. 1; PI 31, fig. 15; Pl. 32, fig. 1; Tab. 2, 4, 6, 8, 9; Fig. 5

Dictyoceras caia, Tab. 9

Dictyophimus craticula, 8(8); PI. 19, fig. 1; Pl. 33, fig. 11; Tab. 2, 4, 6, 8, 9; 6d; Fig. 5

Dictyospyris, $8(7) \mathrm{C}$

ceratospyris, $8(7) \mathrm{C}$

discus, 8(7)Ca; Pl. 16, figs. 4-8; PI. 32, figs. 4-7; Tab. 2, 4, 6, 8, 9; Fig.

gigas, 8(7)Cb; Pl. 16, figs. 9, 10; Pl. 32, figs. 10, 11; Tab. 2, 4, 6, 8, 9; Fig. 5

melissium, 8(7)Cc; PI. 17, figs. 1, 2; Pl. 32, fig. 13; Tab. 4, 6, 9; Fig. 5

sphaera, 8(7)Cd; Pl. 17, figs. 3-5; PI. 32, figs. 14-18; Tab. 1-6, 8, 9; Figs. 4, 6 triloba, 8(7)C

Diploplegma, $8(2) \mathrm{G}$

cinctum, $8(2) \mathrm{G}$

somphum, 7; 8(2)Pc; 8(2)Ga; Pl. 4, fig. 5; Pl. 23, figs. 7, 8; Tab. 2, 4, 6, 8, 9; 6b; Fig. 5

Dipospyris forcipata, 8(7)Df

Dorcadospyris, 8(7)D

alata, 8(7)Da; Tab. 3; 6a

ateuchus, 8(7)Db; Tab. 1, 3, 5, 7, 9; Fig. 6

circulus, 8(7)Dc; Tab. 1, 3, 5, 7, 9; Fig. 6

confluens, 8(7)Dh; 8(7)Dd; Pl. 17, figs. 6-10; Pl. 33, fig. 1; Tab. 1-6, 8, 9; Fig. 5

dentata, 8(7)De; Tab. 1, 3, 5, 7, 9; 6a; Fig. 6

forcipata, 8(7)Df; Tab. 1, 3, 5, 7, 9; 6a; Fig. 6

papilio, 8(7)Dg; Tab. 1, 3, 5, 7, 9; Fig. 6

platyacantha, 8(7)Dh; PI. 17, figs. 11-15; Pl. 33, fig. 2; Tab. 1-6, 8, 9; Figs. 5, 6

praeforcipata, 8(7)Di; Tab. 1, 3, 5, 9; Fig. 6

pseudopapilio, 8(7)Dj; Tab. 3, 5

spinosa, 8(7)Dk; Tab. 1, 3, 5, 7, 9; Fig. 6

Druppatractus, $8(2) \mathrm{N}$

hippocampus, 8(2)N

ostracion, $8(2) \mathrm{N} ; 8(2) \mathrm{Na}$

parasagittatus, $8(2) \mathrm{Na}$

polycentrus, $8(2) \mathrm{Na}$

santaeannae, $8(2) \mathrm{Na}$

trichopterus, $8(2) \mathrm{Na}$

Druppatractylis, $8(2) \mathrm{N}$

Druppocarpus, $8(2) \mathrm{L}$

ananassa, 8(2)L

Ellipsidium

cultum, $8(2) \mathrm{La}$

mendosum, $8(2) \mathrm{La}$

Ellipsoxiphetta, 8(2)N

Ellipsoxiphus

cultum, 8(2)Aa

flosculus, 8(2)N

Entapium, 8(2)H

chaenapium, 7; 8(2)Kc; 8(2)Ha; Pl. 3, fig. 3; PI. 23, figs. 9-12; Tab. 4, 6, 9; Fig. 5

regulare, 8(2)H; 8(2)Hb; Pl. 1, figs. 10-19; Pl. 24, figs 1-3; Tab. 2, 4, 6,$8 ; 6 \mathrm{~b} ; 6 \mathrm{c} ;$ Fig. 5
Eribotrys, 8(11)

Eusyringium

fistuligerum, Tab. 9; Fig. 6

lagena, Tab. 9

Gamospyris circulus, 8(7)Dc

Giraffospyris, 8(7)E cyrillium, 8(7)Ea; PI. 18, figs. 1-3; Pl. 33, fig. 3; Tab. 2, 4, 6, 8, 9; Fig. 5

lata, 8(7)Eb; Pl. 18, figs. 4-7; PI. 33, fig. 4; Tab. 2, 4, 6, 8, 9; Fig. 5

Haliomma

humboldtii, $8(4) \mathrm{Ca}$

humboldti var., 8(4)C

inerme, $8(2) \mathrm{P}$

radicatum, $8(7) \mathrm{A}$

triactis, $8(4) \mathrm{Cd}$

Heliodiscomma, 8(4)C

Heliodiscus

cingillum, 8(4)C; $8(4) \mathrm{Ca}$

heliasteriscus, $8(4) \mathrm{Cc}$

humboldti, 8(4)Ca

linckiaformis, 8(4)Aa

pentasteriscus, $8(4) \mathrm{Cc}$

Heliostaurus, 8(4)C

Heliostylus, 8(4)B

sp(p)., 8(4)B; P1. 8, figs. 1-7; PI. 26, figs. 10-12; Pl. 27, fig. 1; Tab. $2-8,9 ; 6$; Figs. 5,6

Heterospongus varians, $8(2) \mathrm{Bd}$

Hexacontium, 8(2)I

palaeocenicum, 8(2)Ia; Pl. 4, fig. 2; Pl. 24, fig. 4; Tab. 2, 4, 6, 8, 9; 6b; Fig. 5

phaenaxonium, $8(2) \mathrm{I}$

Hexalonche, 8(2) J

phaenaxonia, 8(2)J

(?)sp. A, 8(2)Ja; Pl. 4, fig. 1; Pl. 24, fig. 5; Tab. 2, 4, 6, 8, 9; 6b; Fig. 5

Hexaspyris papilio, 8(7)Dg

Lamptonium

colymbus, Tab. 9

fabaeforme chaunothorax, Tab. 9

fabaeforme constrictum, Tab. 9

fabaeforme fabaeforme, Tab. 9

incohatum, Tab. 9

pennatum, Tab. 9

sanfilippoae, Tab. 9

Liriospyris, 8(7)F

hexapoda, $8(7) \mathrm{F}$

parkerae, $8(7) \mathrm{Fa}$; $6 \mathrm{a}$

stauropora, 8(7)Fb; Tab. 3, 9; 6a; Fig. 6

Lithapium, 8(2)K

anoectum, 7; 8(2)Ka; Pl. 24, figs. 6, 7; Tab. 1-8, 9; Figs. 5, 6

mitra, 8(2)Kb; Tab. 1, 3, 5, 7, 9; Fig. 6

plegmacantha, 7; 8(2)Ha; 8(2)Ka; 8(2)Kc; Pl. 3, figs. 1, 2; Pl 24, figs. 8, 9; Tab. 2-6, 9; Fig. 5

Lithatractus

hederae, $8(2) \mathrm{Na}$

pierinae, $8(2) \mathrm{Ca}$

Lithelius, 8(3)A

foremanae, 7; 8(3)Ab; 8(3)Aa; Pl. 7, figs. 1-6; Pl. 26, figs. 4, 5; Tab. $2,4,6,8,9$; 6b; Fig. 5

hexaxyphophorus, 7; 8(3)Ab; Pl. 7, figs. 7-9; PI. 26, figs. 6, 7; Tab. 4, 6, 8, 9; 6c; Fig. 5

spiralis, 8(3)A

Lithochytris

archaea, Tab. 9

vespertilio, Tab. 9; Fig. 6

Lithocyclia, 8(5)A

angusta, 8(5)Ab; 8(5)Aa; Tab. 1. 3, 5, 7, 9; Fig. 6

aristotelis group, 8(5)Ab; Tab. 1-9; Fig. 6

crux, 8(5)Ac; Tab. 1, 3, 5, 7, 9; Fig. 6

ocellus group, 8(5)Ab; 8(5)Ad; Pl. 10, figs. 1, 2; Tab. 1-9; Figs. 5, 6 
Lithomelissa spongiosa, 8(8)A

Lithomespilus, 8(2)L mendosa, 8(2)La; Pl. 4, figs. 6, 7; PI. 24, figs. 10, 11; Tab. 2, 4, 6, 8 , 9; 6b; Fig. 5 phloginus, $8(2) \mathrm{L}$

Lithomitra docilis, Tab. 9; Fig. 6

Lithopera renzae, Tab. 9; Fig. 6

Lophocyrtis biaurita, Tab. 9; Fig. 6 jacchia, Tab. 9; Fig. 6

Lychnocanium bipes, see Lychnocanoma bipes

Lychnocanoma

amphitrite, Tab. 9; Fig. 6

anacolum, Tab. 9

auxilla, Tab. 9

babylonis group, Tab. 9; Fig. 6

bellum, Tab. 9; Fig. 6

bipes, Tab.9; Fig. 6

sp. aff. L. bellum, Tab. 9

Monosphaera, 8(2)F toliapica, $8(2) \mathrm{F}$

Octodendron hamuliferum, 8(2)Bd spathillatum, 8(2)Bd

Orbula

comitata, Tab. 9

discipulus, Tab. 9 ducalis, Tab. 9

Oropagis dolium, $8(2) \mathrm{Kc}$

Paracenodiscus, 8(4)C familiaris, $8(4) \mathrm{C}$

Periphaena, 8(4)A; 8(4)C

cincta, 8(4)Ca

decora, 8(4)C; 8(4)Ca; Pl. 8, figs. 8-10; Pl. 27, figs. 2-5; Tab. 1-4, 6, 8, 9; Figs. 5, 6

delta, 8(4)Cb; Pl. 8, figs. 11, 12; Pl. 27, figs. 6, 7; Tab. 2, 4, 6, 8, 9; Fig. 5

heliasteriscus, 7; 8(4)Cd; 8(4)Cc; Pl. 9, figs. 1-6; Pl. 27, figs. 8, 9; Tab. 2, 4, 6, 8; 6b; 6c; Fig. 5

tripyramis triangula, 8(4)Ce; Pl. 9, Figs. 10, 11; Tab. 4, 6, 8, 9; Fig. 5

tripyramis tripyramis, 7; 8(5)Ad; 8(4)Cd; Pl. 9, figs. 7-9; Tab. 4, 6, 8, 9; 6c; Fig. 5

Perizona, 8(4)C scutella, $8(4) \mathrm{C} ; 8(4) \mathrm{Ca}$

Petalospyris confluens, $8(7) \mathrm{Dd}$ flabellum, 8(7)Bb platyacantha, $8(7) \mathrm{Dh}$

Phacostylus, 8(4)B amphistylus, 8(4)B caudatus, 8(4)B

Phacotriactis, 8(4)C triangula, $8(4) \mathrm{C} ; 8(4) \mathrm{Ce}$

Phormocyrtis annosa, 8(10)Ca cubensis, Tab. 9 striata exquisita, Tab. 9 striata striata, Tab. 9; Fig. 6 turgida, Tab. 9

Pipettaria tubaria, 8(2)Dc

Pipettella prismatica, $8(2) \mathrm{Db}$

Podocyrtis, 8(10)B

ampla, 7; 8(10)Be; 8(10)Ba; Tab. 1, 3-6, 9; Fig. 5 aphorma, 8(10)Bg; Pl. 20, figs. 7, 8; Tab. 2. 4, 6. 9; Fig. 5

chalara, 8(10)Bh; Tab. 1-6, 9; Fig. 6

diamesa, 7; 8(10)Bc; $8(10) \mathrm{Be} ; 8(10) \mathrm{Bb}$; Pl. 20, figs. 9, 10; Pl. 35; figs. 10, 11; Tab. 4, 6, 9; Fig. 5

dorus, 7; 8(10)Bc; Pl. 35, figs. 12-14; Tab. 4, 6, 9; Fig. 5

goetheana, 8(10)Bi; Tab. 1-6, 9; Fig. 6

mitra, 8(10)Bj; Tab. 1-6, 9; Figs. 5, 6

papalis, 7; 8(10)Bd; Pl. 20, figs. 11-14; Pl. 36, figs. 2, 3; Tab. 1-9; Figs. 5, 6

phyxis, 7; 8(10)Be; Tab. 4, 6, 9; Fig. 5 platypus, 7; 8(10)Bf; Pl. 21, figs. 1-3; Pl. 36, figs. 4, 5; Tab. 4, 6, 9; Fig. 5 sinuosd?, 8(10)Bk; Tab. 1-6, 9; Fig. 5

trachodes, 8(10)B1; Tab. 4, 6, 9; Figs. 5, 6

Polysolenia, 8(1); Pl. 22, fig. 1

Porodiscus

charlestonensis, $8(6) \mathrm{Db}$

circularis, 8(6)Ea

Psychospyris, $8(7) \mathrm{Cc} ; \mathbf{8 ( 7 ) G}$ grandis, 8 (7)Ga; Tab. 3; 6a intermedia, 8(7)Gb; Tab. 3, 9; 6a; Fig. 6 parva, 8(7)Ge; Tab. 3, 5, 7, 9; Fig. 6

Pterocodon ampla, Tab. 9 tenellus, Tab. 9

Rhabdolithis, $\mathbf{8 ( 7 )} \mathbf{H}$ ellida, 7; 8(7)Hb; 8(7)Ha; Pl. 18, figs. 8-11; Pl. 33, figs. 5-8; Tab. 2, $4,6,8,9 ; 6$ b; Fig. 5

pipa, 7; 8(7); 8(7) H; 8(7)Hb; Pl. 18, figs. 12-16; PI. 33, figs. 9, 10; Tab. 2, 4, 6, 8, 9; 6c; Fig. 5

Rhopalocanium ornatum, Tab. 9; Fig. 6

Sethocorys cristata, 8(9)Bc

Sethostaurus cruciatus, $8(4) \mathrm{C}$

Sethostylus, 8(4)C dentatus, 8(4)B distyliscus, 8(4)C

Siphocampe sp. aff. S. corbula, Tab. 9; Fig. 6

Soreuma magnificum, 8(8)B

Sphaerostylus agdaraensis, $8(2) \mathrm{Pa}$

Spirocyrtis sp. aff. S. scalaris, Tab. 9; Fig. 6

Spongaster klingi, 8(6)C

Spongasteriscus

berminghami, 8(6)C

cruciferus, $8(6) \mathrm{Cb}$

Spongatractus, $\mathbf{8 ( 2 )} \mathbf{M}$

balbis, 7; 8(2)Mb; 8(2)Ma; Pl. 2, figs. 1-3; Pl. 25, figs. 1, 2; Tab. 2, 4, 6, 8, 9; Fig. 5

pachystylus, 7; 8(5)Ad; 8(2)Mb; Pl. 2, figs. 4-6; Pl. 25, fig. 3; Tab. 1-9; Figs. 5, 6

Spongodiscus, 8(6)D; 8(6)C americanus, 8(6)Ca; Pl. Il, figs.9-13; Pl. 27, fig. 11; Pl. 28, fig. 9; Tab. 2, 4, 6, 8, 9; 6b; Fig. 5

biconcavus, $8(6) \mathrm{Ca} ; 8(6) \mathrm{Cb}$

communis, $8(6) \mathrm{Ca}$

cruciferus, 8(6)Ac; 8(6)Cb; Pl. 11, figs. 14-17; Pl 28, figs. 10, 11; Tab. 2, 4, 6, 8, 9; Fig. 5

phrix, 8(6)Ca; 8(6)Ce; Pl. 12, figs. 1, 2; Pl. 29, fig. 2; Tab. 2, 4, 6, 8, 9; Fig. 5

pulcher, $8(6) \mathrm{Ca}$; 8(6)Cd; Pl. 12, figs. 3-5; Pl. 29, figs. 3, 4

quartus bosoculus, 8(6)Cf; Pl. 12, figs. 8-10; Pl. 29, fig. 7; Tab. 2, 4, $6,8,9 ; 6 \mathrm{~b}$; Fig. 5

quartus quartus, 8(6)Ce; Pl. 12, figs. 6, 7; Pl. 29, figs. 5, 6; Tab. 2, $4,6,8,9$; Fig. 5

resurgens, $8(6) \mathrm{C}$

rhabdostylus, 8(6)Cg; PI. 13, figs. 1-3; Pl. 30, figs. 1, 2; Tab. 2, 4, 6, 8, 9; 6c; Fig. 5

sp., 8(6)Cb; Pl. 11, figs. 18, 19; Pl. 29, fig. 1

Spongomelissa, 8(8)A

adunca, 7; 8(8)Ab; 8(8)Ac; 8(8)B; 8(8)Aa; Pl. 19, figs. 3, 4; Pl. 34, figs. 1-6; Tab. 2, 4, 6, 8, 9; 6b; Fig. 5

cucumella, 8(8)Ab; Pl. 19, figs. 6, 7; Pl. 34, figs. 7-10; Tab. 2, 4, 6, 8 , 9; Fig. 5

euparyphus, 7; 8(8)Ab; 8(8)Ac; Pl. 20, fig. 1; Pl. 34, figs. 12, 13; Tab. 2, 4, 6, 8, 9; Fig. 5

Spongoprunum

densum, $8(2) \mathrm{Mb}$

markleyense, $8(2) \mathrm{Mb}$

Spongosphaera

pachystyla, $8(2) \mathrm{M} ; 8(2) \mathrm{Mb}$

rhabdostyla, $8(6) \mathrm{Cg}$

Spongoxiphus, 8(2)M

prunococcus, $8(2) \mathrm{M} ; 8(2) \mathrm{Mb}$

Staurodictya quartus, $8(6) \mathrm{Ce}$ 
Staurodiscus, 8(4)C

primus, $8(4) \mathrm{C}$

Stichocorys

armata, Tab. 9; Fig. 6

delmontensis, Tab. 9; Fig. 6

diploconus, Tab. 9; Fig. 6

wolffii, Tab. 9; Fig. 6

Stuermeria, 8(2)A

hollandei, $8(2) \mathrm{A}$

Stylodiscus, 8(4)B

endostylus, 8(4)B

Stylosphaera, $8(2) \mathrm{N}$

calliope, $8(2) \mathrm{N}$

coronata coronata, 7; 8(2)Nb; 8(2)Na; Pl. 1, figs. 13-17; P1. 25, fig.

4; Tab. 2, 4, 6, 8; 6b; 6c; Fig. 5

coronata laevis, 8(2)Nb; Pl. 1, fig. 19; Pl. 25, figs. 5, 6; Tab. 4, 6, 9; 6c; Fig. 5

coronata sabaca, 7; 8(2)Nc; Pl. 1, fig. 18; Pl. 25, figs. 7-8; Tab. 4, 6, 9; Fig. 5

goruna, 8(2)Na; 8(2)Nd; Pl. 1, figs. 20-22; Pl. 25, figs. 9, 10; Tab. 2,

$4,6,8,9 ; 6$; Fig. 5

hexaxyphophora, 8(3) Ab

hispida, 8(2)N

liostylus, 8(2)Aa

minor, 8(2)Aa

Stylosphaerantha, $8(2) \mathrm{N}$

Stylospongia huxleyi, 8(6)D

Stylotrochus, 8(6)D

alveatus, 8(6)Da; Pl. 13, figs. 4, 5; PI. 30, figs. 3, 4; Tab. 2, 4, 6, 8 , 9; 6b; Fig. 5

charlestonensis?, 8(6)Dc; 8(6)Db; Pl. 13, figs. 6-8; Pl. 30, figs. 5, 6 geddesi, 8(6)Dc

nitidus, 8(6)Db; 8(6)Dc; PI. 13, figs. 9-14; Pl. 30, figs. 7-10; Tab. 2,

4, 6, 8, 9; Fig. 5

quadribrachiatus multibrachiatus, 7; 8(6)De; Pl. 14, figs. 3, 4; PI. 31, figs. 2, 3; Tab. 2, 4, 6, 8, 9; Fig. 5

quadribrachiatus quadribrachiatus, $7 ; 8(6) \mathrm{Db} ; 8(6) \mathrm{De} ; 8(6) \mathrm{Dd}$; PI.

14, figs. 1, 2; Pl. 31, fig. 1; Tab. 2, 4, 6, 8, 9; Fig. 5

rhabdostylus, $8(6) \mathrm{Cg}$

Thecosphaera, $\mathbf{8}(\mathbf{2}) \mathbf{0}$

californica, 8(2)Pd

larnacium, 8(2)Oa; Pl. 3, figs. 4-6; Pl. 25, figs. 13, 14; Tab. 2, 4, 6, 8 , 9; 6b; Fig. 5

rotunda, $8(2) \mathrm{Pd}$

triplodictyon, $8(2) \mathrm{O}$

Thecosphaerella, 8(2) $\mathbf{P}$

cf. agdaraensis, 8(2)Ia; 8(2)Pa; Pl. 2, figs. 7-9; Pl. 25, fig. 15; Tab. 2-9; Figs. 5, 6

glebulenta, 8(2)Ia; 8(2)Pb; Pl. 3, figs. 12, 13; Pl. 26, fig. 1; Tab. 4, $6,8,9$; Fig. 5

ptomatus, 7; 8(2)Ga; 8(2)Pc; Pl. 3, figs. 14-18; Pl. 26, fig. 2; Tab. 2, $4,6,8,9 ; 6$; Fig. 5

rotunda, 8(2)Ia; 8(2)Pd; Pl. 3, figs. 7-11; Pl. 26, fig. 3; Tab. 2, 4, 6 , 8 ; 6b; 6c; Fig. 5
Thecotapus, 8(2)O

Theocampe

amphora group, Tab. 9; Fig. 6

armadillo group, Tab. 9; Fig. 6

mongolfieri, Tab. 9; Fig. 6; 8(4)Ca

pirum, Tab.9; Fig. 6

urceolus, Tab. 9; Fig. 6

Theocorys

acroria, Tab. 9

anaclasta, Tab. 9

anapographa, Tab. 9

phyzella, Tab. 9

spongoconum, Tab. 9; Fig. 6

Theocotyle

alpha, Tab. 9

auctor, Tab. 9

cryptocephala conica, Tab. 9

cryptocephala cryptocephala, Tab. 9

cryptocephala nigriniae, Tab. 9

ficus, Tab. 9; Fig. 6

fimbria, Tab. 9

Theocyrtis, 8(10)C

annosa, 8(10)Ca; Tab. 1, 3, 5, 7, 9; Fig. 6

tuberosa, 8(10)Cb; Tab. 1, 3, 5, 7, 9; Fig. 6

Thyrsocyrtis

bromia, Tab. 9; Fig. 6

hirsuta hirsuta, Tab. 9

hirsuta robusta, Tab. 9

hirsuta tensa, Tab. 9

rhizodon, Tab. 9; Fig. 6

tarsipes, Tab. 9

tetracantha, Tab. 9; Fig. 6

triacantha, Tab. 9; Fig. 6

Triactis, $8(4) \mathrm{C}$

tripyramis, $8(4) \mathrm{Cd}$

tripyramis triangula, $8(4) \mathrm{Ce}$

Triactiscus, $8(4) \mathrm{C}$

Trigonactura angusta, 8(5)Aa

Trissocyclus stauroporus, $8(7) \mathrm{Fb}$

Tristylospyris, 8(7)I

palmipes, 8(7)I

triceros, 8(7)Ia; Tab. 1-7, 9; Fig. 6

Velicucullus, $\mathbf{8 ( 8 ) B}$

spp., 8(8)B; Pl. 20, figs. 2-6; Pl. 34, fig. 14

Xiphatractus mirificus, $8(2) \mathrm{Ca}$

Xiphodictya

amphixiphos, 8(6)Ea

staurospira, 8(6)E

Xiphosphaera irinae, 8(2)Aa

Xiphospira, 8(6)E

circularis, 8(6)Ea; Pl. 14, figs. 5-12; Pl. 31, figs. 4-7; Tab. 2, 4, 6, 8; $6 \mathrm{~b} ; 6 \mathrm{c}$; Fig. 5

Xiphostylus minimus, 8(2)Aa 